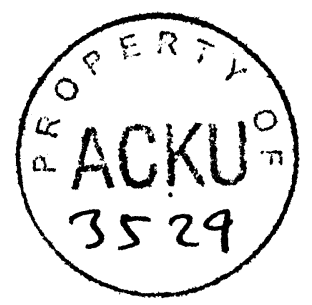

يففن علىنانيمتيار
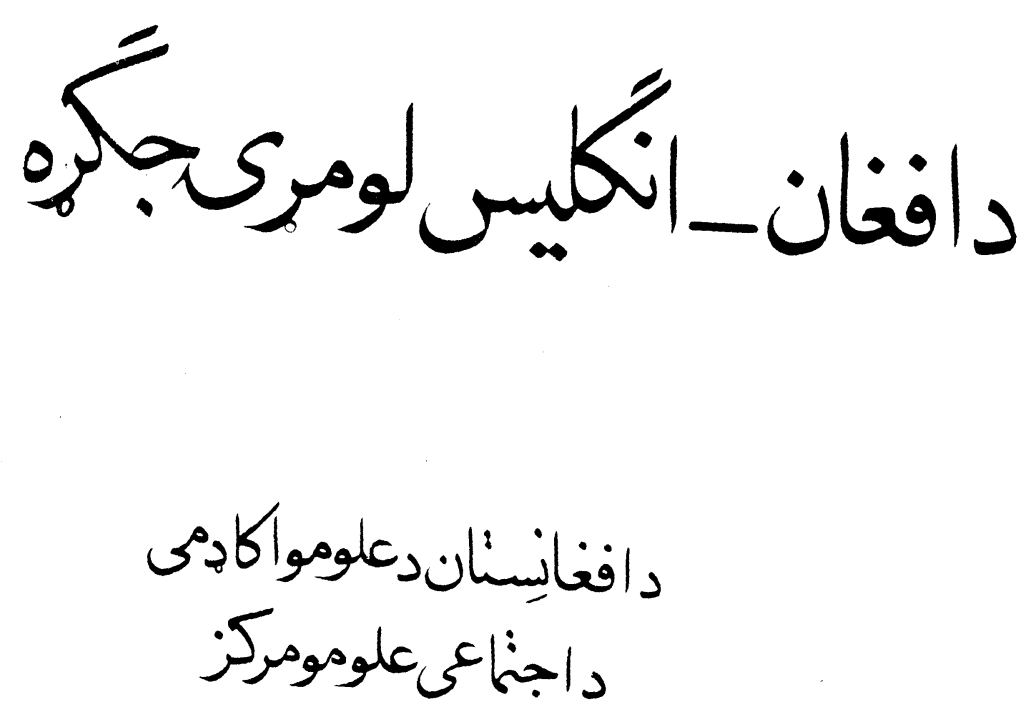

كبل 


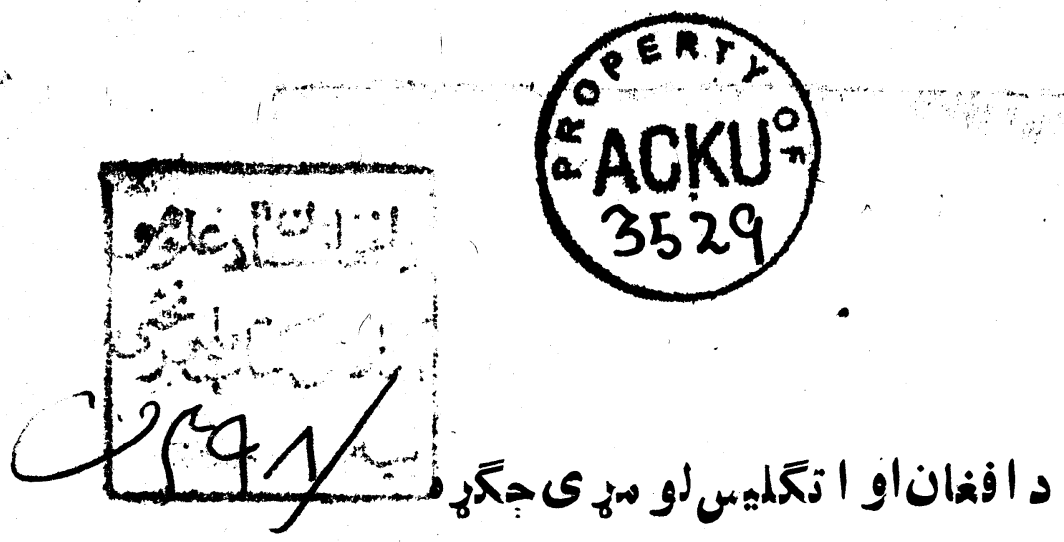

مؤلف

علىخان إيكتيار

دا فغانسئأند علومو اكا دمى

دتو لنيز و علو مو سركز

دتار يخ ا نستيتوت

كابل: ابهی

- 941P 


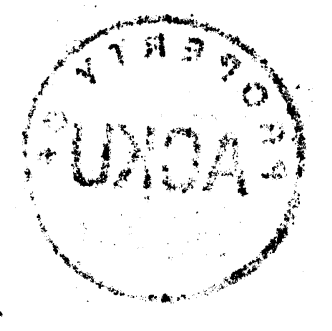

شعبdمانوتايبت

$$
\begin{aligned}
& \text { دجإِحاى : دو لتى رطبعه } \\
& \text { دجاب كال : } \\
& \text { دجاب شعير : . . 1 تو كل }
\end{aligned}
$$

دكتابنو م دافغاناو انكليسلو مزى جكيه

دمو لف نوم . : علىخان بكتيار 


\section{فهر ست}

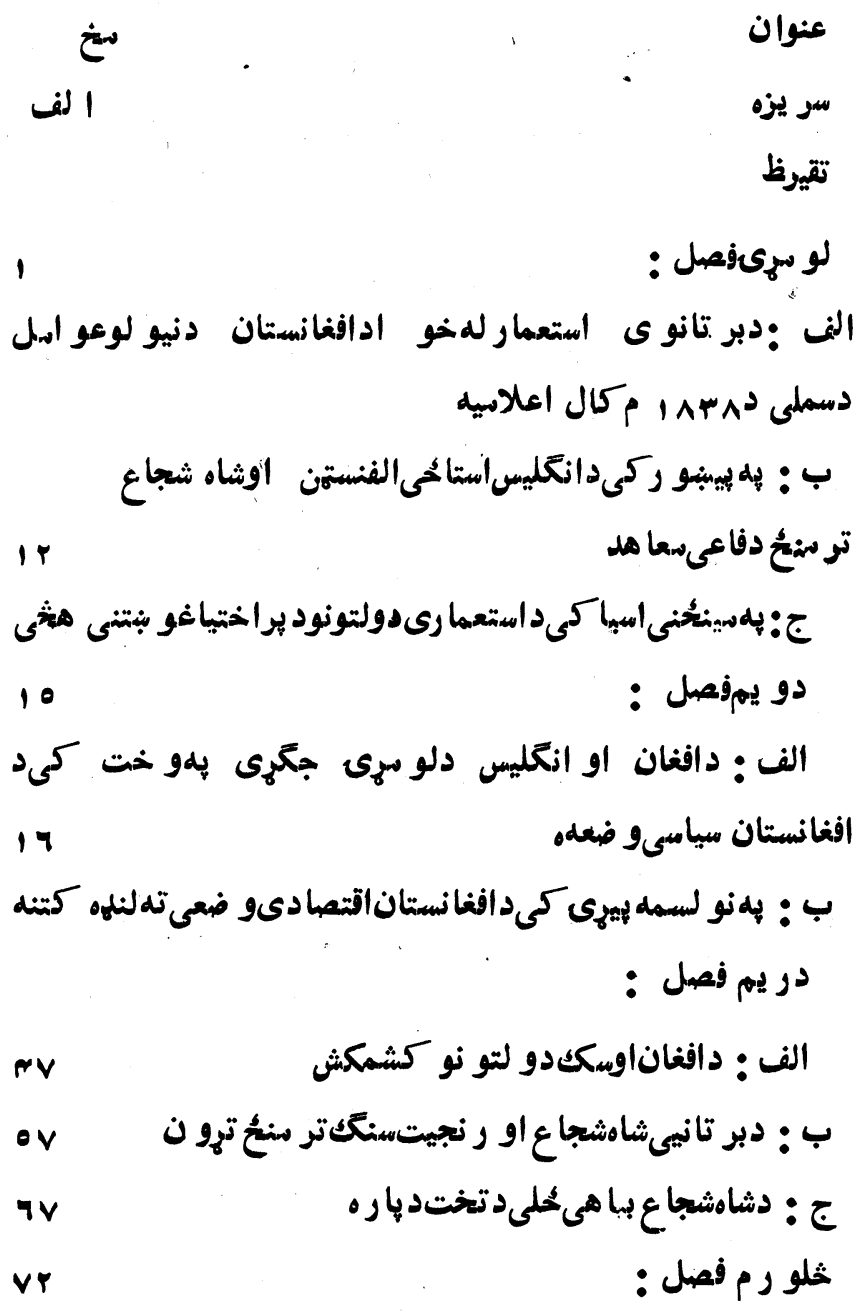

الف 


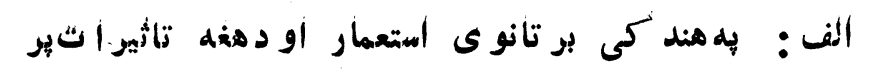
vr |فغانستان

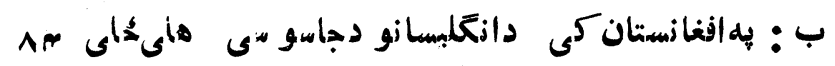
91

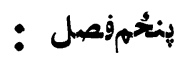

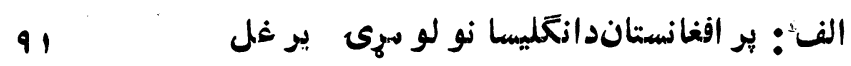

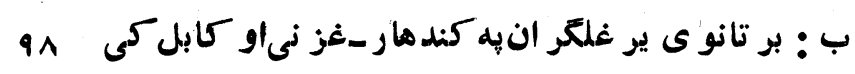

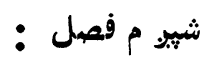

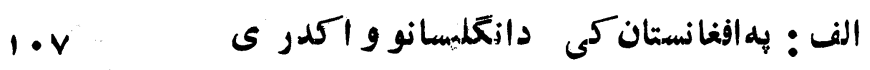

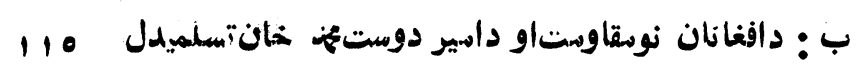

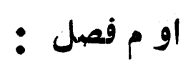

irr الف : دافغانستان خلكو ملى باخون

irs ب : دبر تانو ى استعمار ى لبنكو لهمنيخه تلل

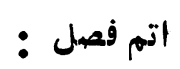

الف : دبر تانو ى استعها رويها نود بايللىبر ستيز دكتلو دباره
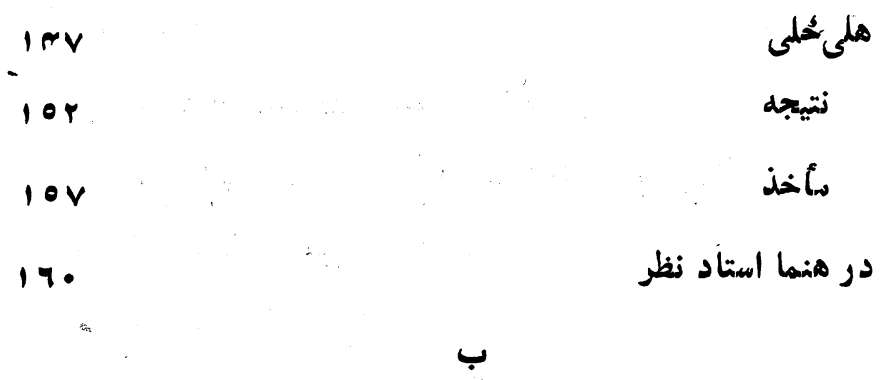
5

سمون ليكـ

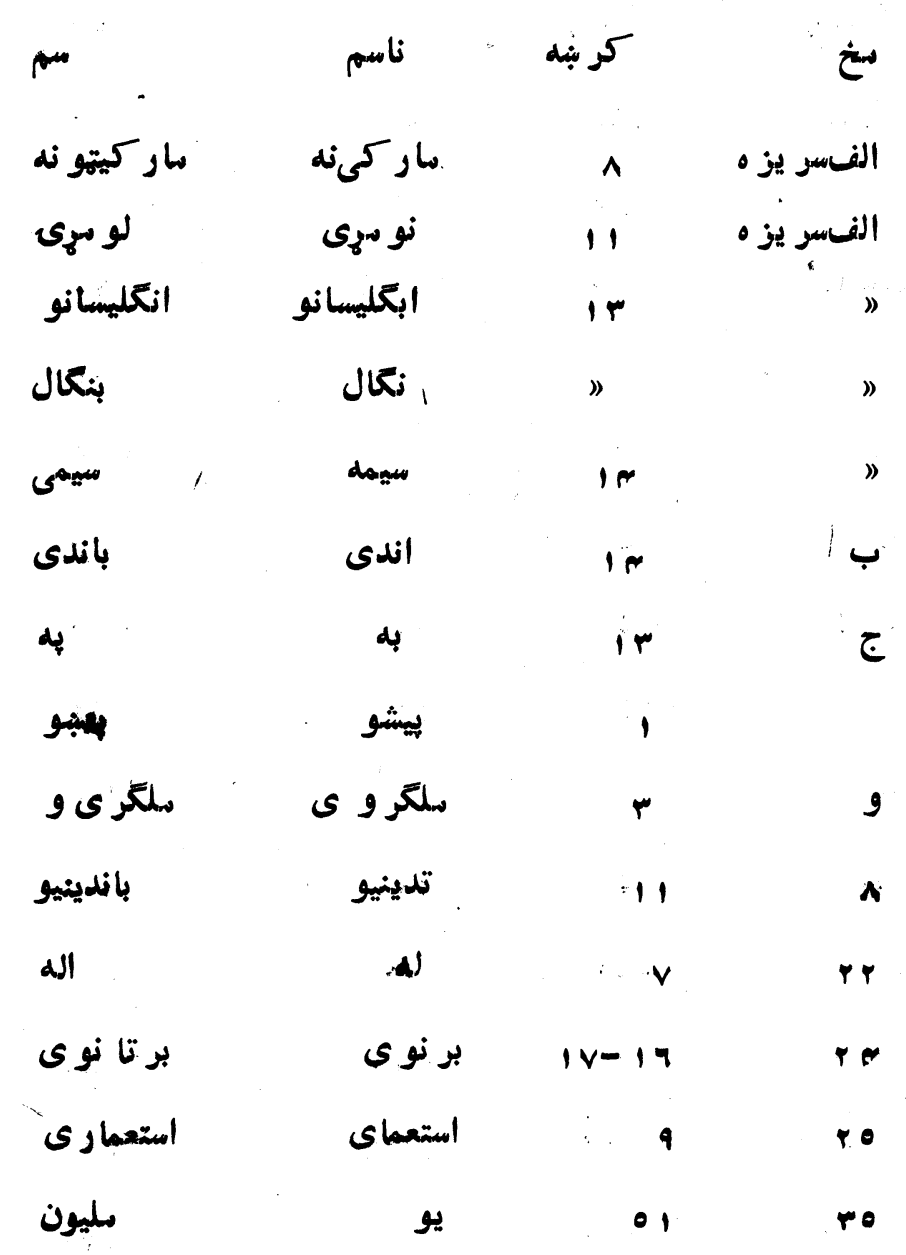




\begin{tabular}{|c|c|c|c|}
\hline م م م & ناسم & كربه & 5 \\
\hline زكاح & تكא & 01 & $r q$ \\
\hline برخلاف. & ير خلاك & r & 07 \\
\hline استقبال & المتقبا & iv & or \\
\hline غالى & خلى & $r 1$ & 71 \\
\hline برتا نوى & تانوى & $r$ & 9. \\
\hline لار & $y$ & 1. & qr \\
\hline غزنى & غز & 1 & 118 \\
\hline بنه & ينه & • & irr \\
\hline كاتنجو & باتجو & 1.1 & Irr \\
\hline ir & $|r|$ & 11 & irr \\
\hline bet & يا & 1 & Irr \\
\hline بل بته & ليته & ir & iv \\
\hline يو سى & يوميب & $r$ & ine \\
\hline بوها & 10 & 11 & $1 \pi 0$ \\
\hline تعمر و نه & تغمر وه & iv & IrI \\
\hline معنو ى & "معنو & ir & ler \\
\hline استخاز ى & امتاندى & 18 & 170 \\
\hline
\end{tabular}




\section{تقو يظ}

دافغاناو انكليسلو. سري جكَه تر عنو ان لاندي علدى او. تحقيقىاثو

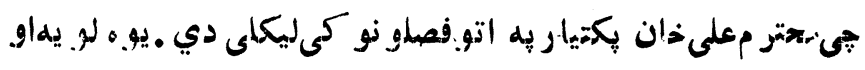

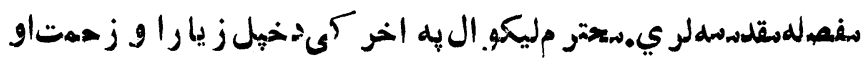

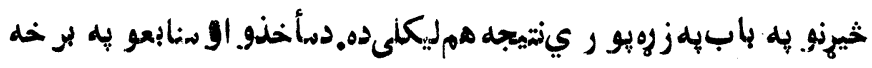

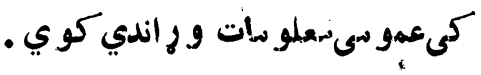

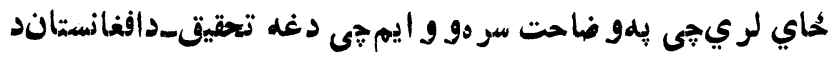

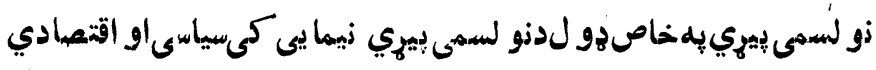
و ضع، تحو لاتاو هر ارخيز عو اسلخير لشنوي يدي .

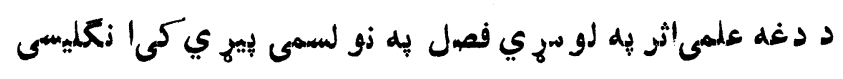

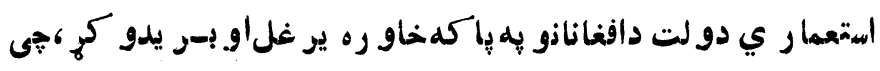
دتار يخ بانهى بانكر يز انو ددغهتو رعمل او غيرانسانى سياست بهابر خه كى بإو رمعلو مات خركند و ي.

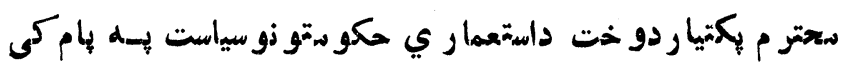
نيولى او خبل نظر داسىخركند و ي : دانكر يز بر اختيا غو بنتو نكو او

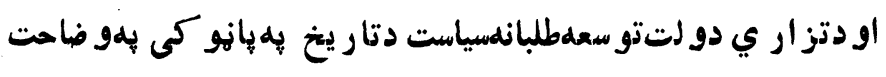

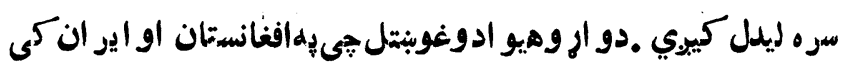
خهل سياسىنفو ذايم كري ترخوله دي لار ي خهيل اقتصادي هدفونه ترلاسه كري ـ بير دغهمو ضوع باندي ليكو ال دقيق او علمى تحقيق كري الفي 


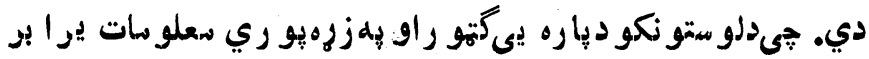
كريدي .

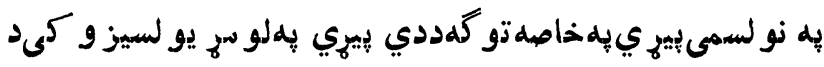

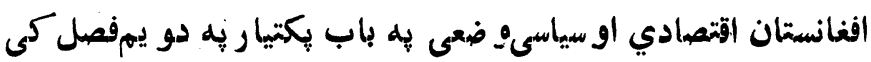
نوي معلو نيت و و اندي كوي.

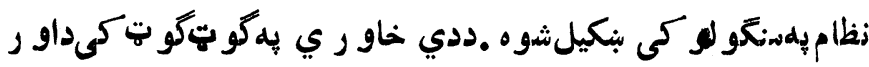

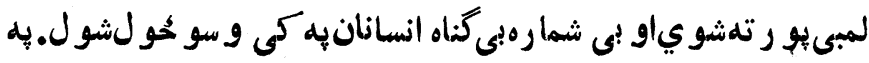

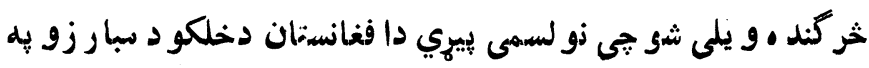

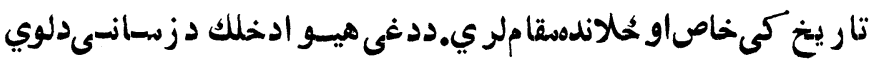

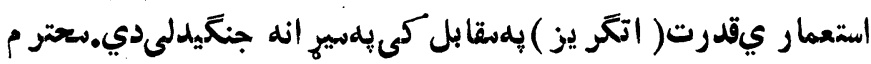

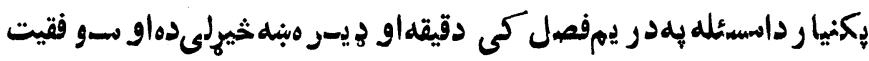

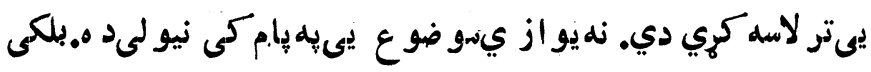

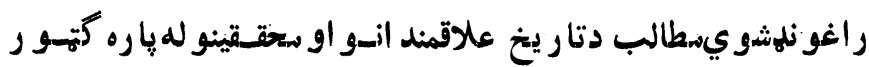

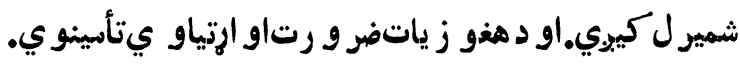

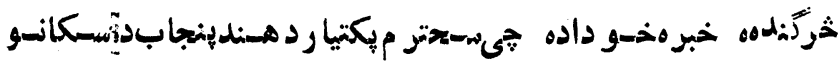

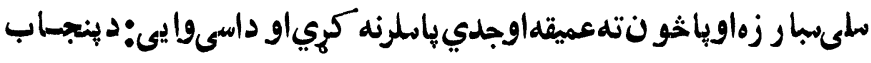

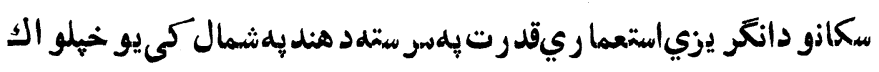

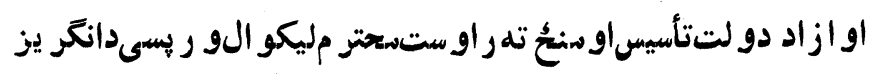
حكو متناورهاو غير انسانىسياست بهمو ردكى بيى به افغانستسانكى

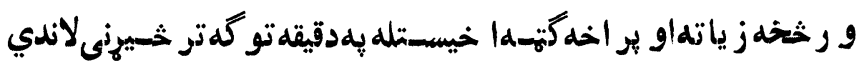

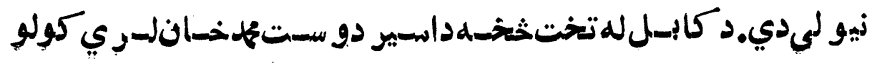


خُخه هدفداوهتر خو دشاهشجاع خبل نبودي متتحدير تختـ كبنينسوى.

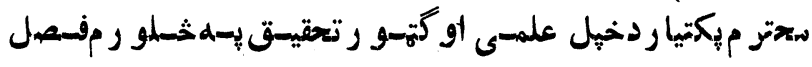

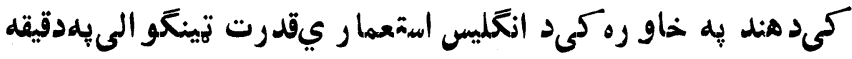

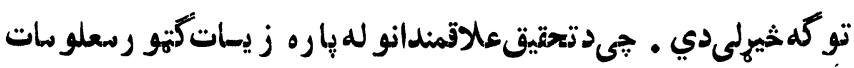
بو ابر كري دي. ليكو ال هندتهد انغكر يز انو راتككاو دهنى داستعمار ريسياست ناوره اغيزي دافغانستان لهه سياسى ،اجتماعىاو اقتصادي وضع باندي تحليلوي جى البتهد نو لسمى بِيري تار يخ جر يسانداخبره

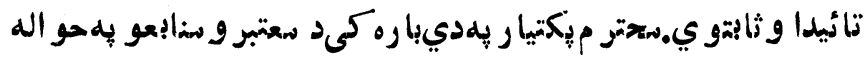

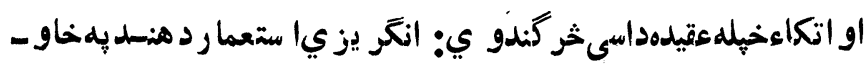

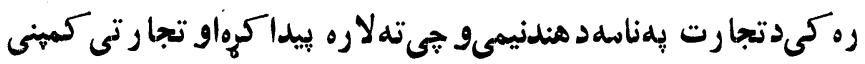

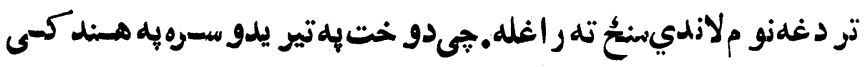

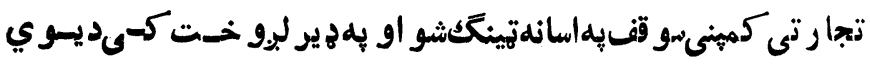

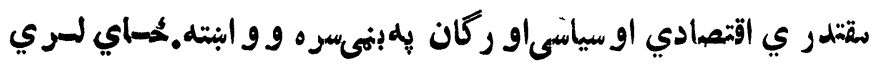

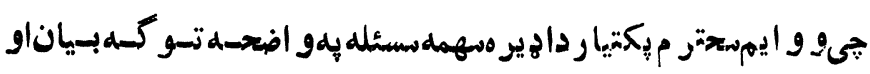

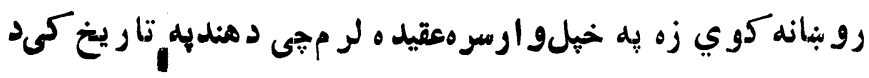

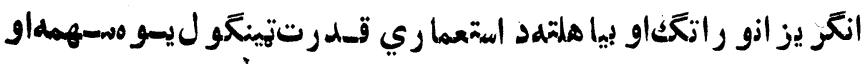
دخير لو ولم مو ضوع دهد .

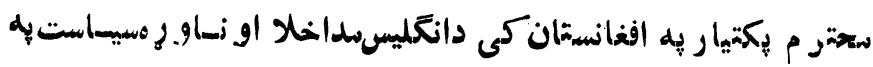

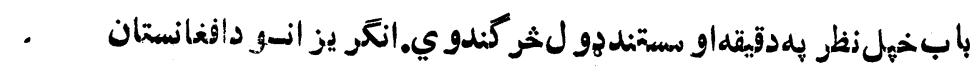




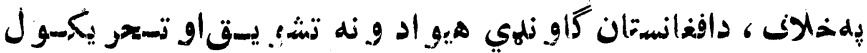

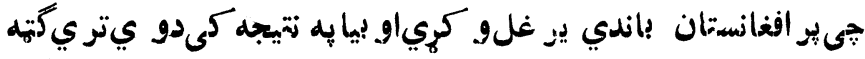

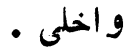

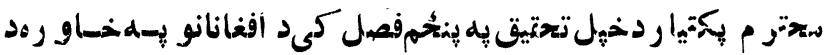

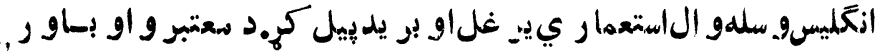

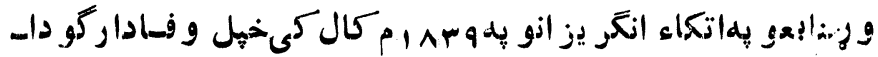

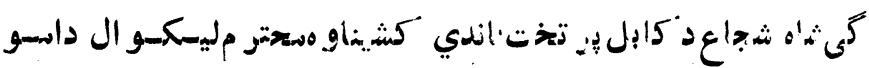

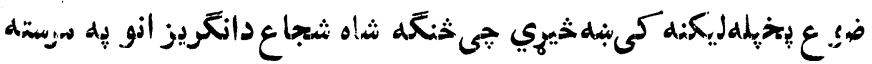

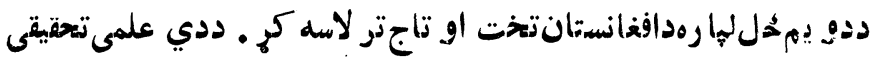

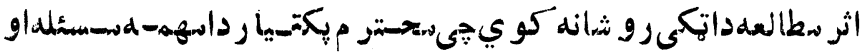

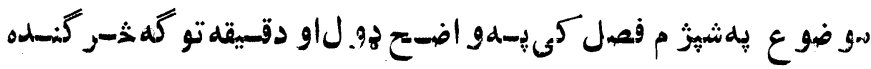

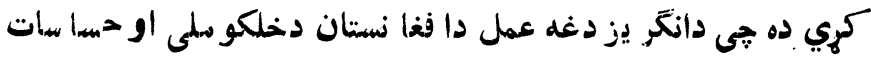

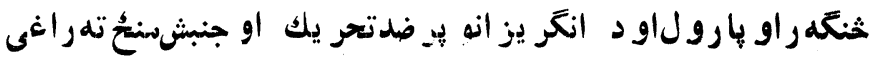

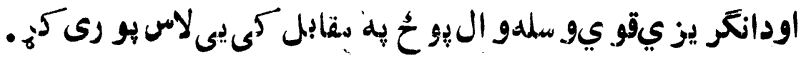

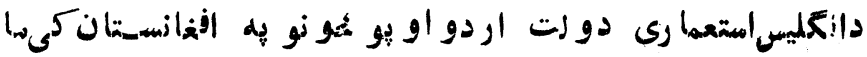

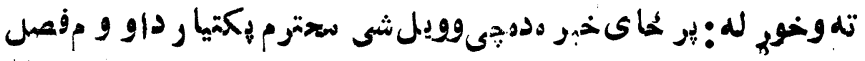
مطالب همد انكر يز يوغل او لشكر كشى تهاختصاص كري،جيىدلو ستو نكو تو جلههمو توتجكو. تهر اكرى زو لىده.

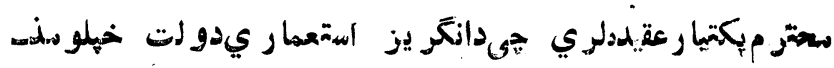




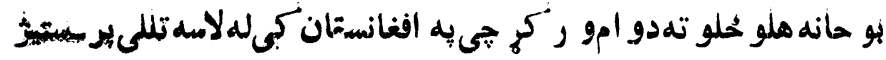

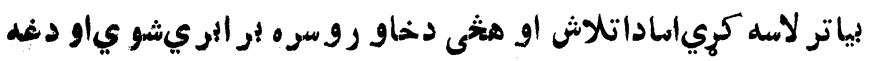

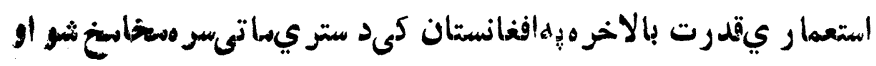

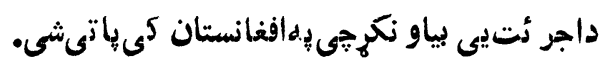

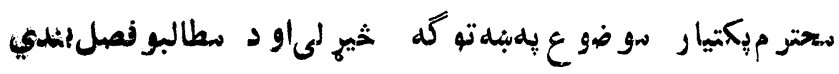

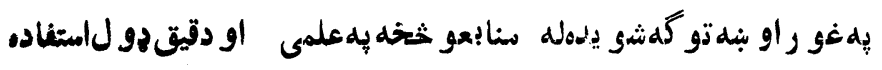

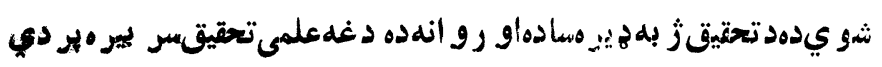

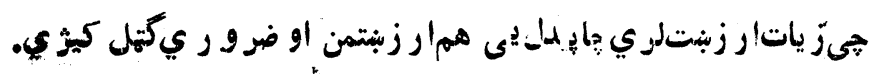

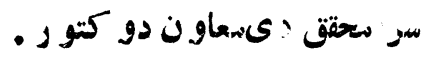

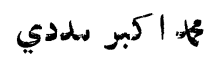




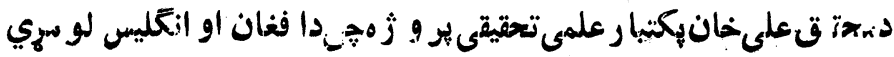

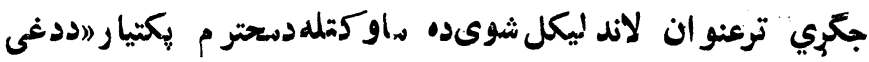

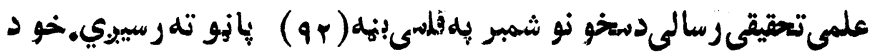
دهر سالهدمقدسى بهلشمو لد سلو متخو نو بهحدو دكى كيداي شى. ر ساللد

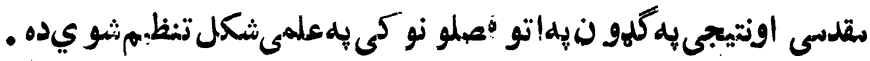

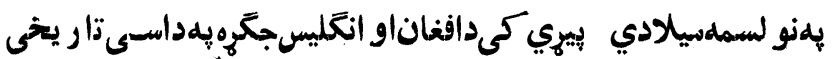

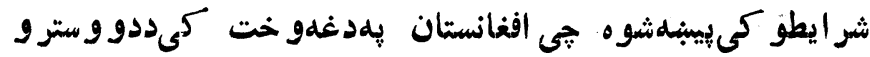

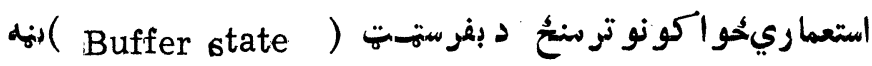
غو رهكيون. للهيوي خوادروس تزار ي اسبراتو ري دتوسعى

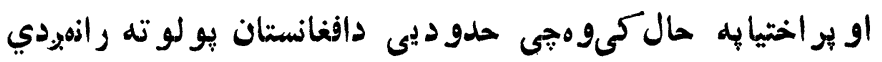

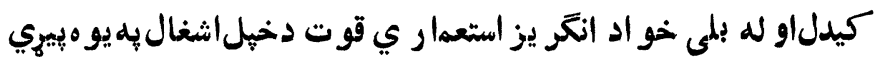

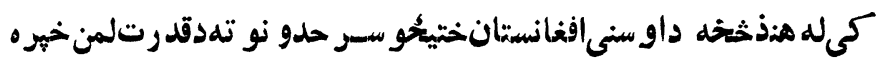
كريو ه.دغوسترواستعماريقوتو نو يهلويد يزهبوله كىاير اذاويهختيع كى دسكانو گو هاكى دو لت يهافغانستيان باندى دتيريله با رملمسول .

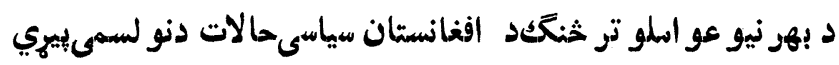
افغانى شهز ادهكانو د متخالفثو نو يه نتيجه كى متخصو صاًله شاه زمان خخلو رو ستلميخ بلخر ابيد و شول لاو دغو كو رنيو شخه و د بهر نيو استعمار ي كمو اكو نو يلهتيوه بيادانكر يزاستعماالف 
ر يقوتتهد افغانستان يهد ننيو جار وكى دسخامخ لاسوهنى او تيري

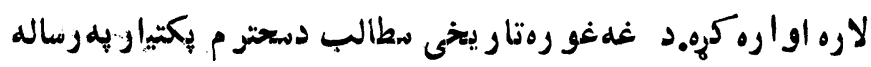
كى به تفصيل سره تحليل شوى دى.

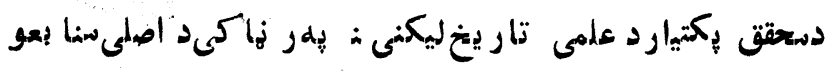

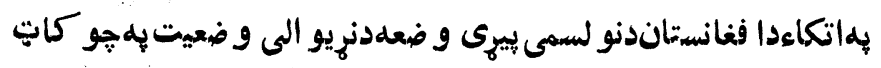

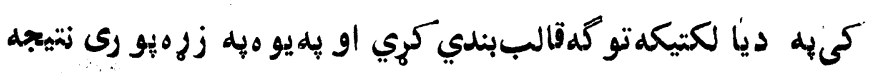
باندي يى سنتج كريدد . وبنتيا هم دوسالى ليكو ال، دو جوبو اوستو سانه

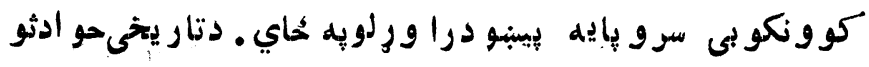

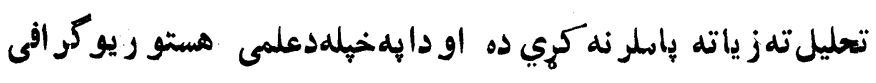
داصولوسره سمه خيرنه كنه كيبوي •

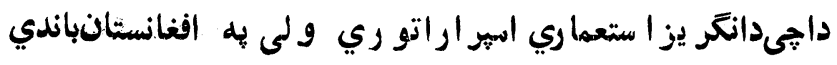

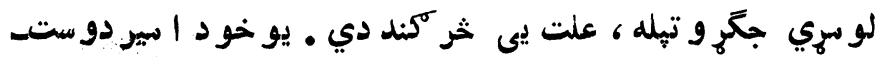

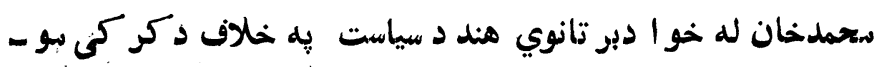

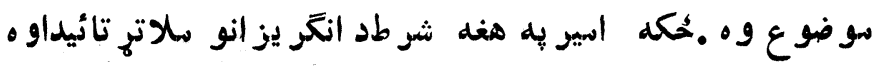

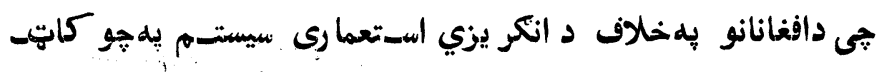
كى نوي راباخول شوي قوت ياد سكيا نو عروج, مبخنيوبيوشه.

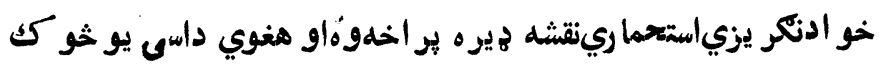

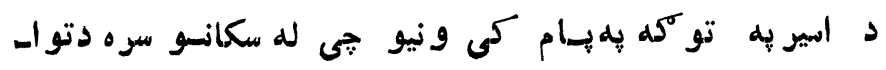

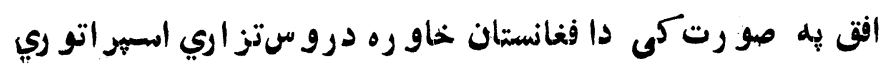

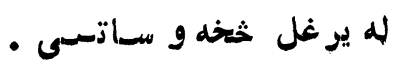


دشاة شبجاع تدرت تلهرسول دانكو يزي استعهمار د همدغسى نقشتى

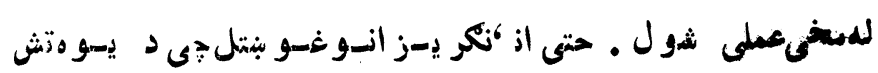

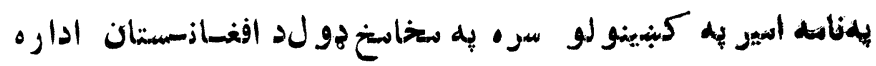

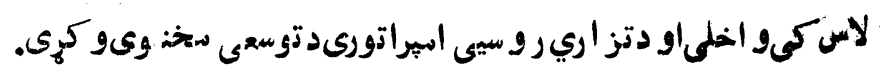

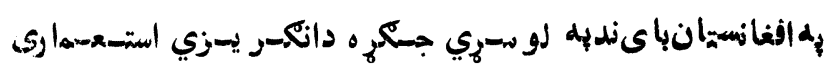

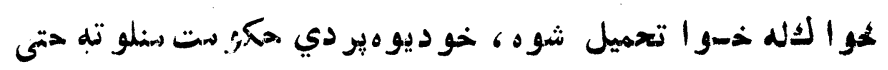

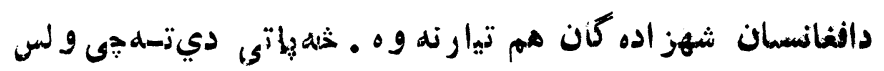

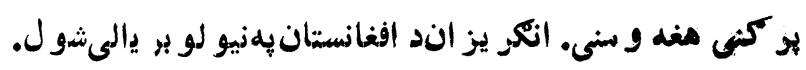
خوو يم نلثول كولى د غه قبضه وساتسى اود هيو ادسليو نم

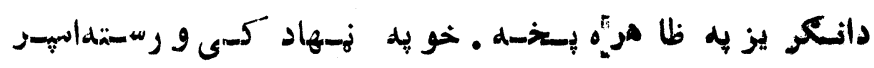

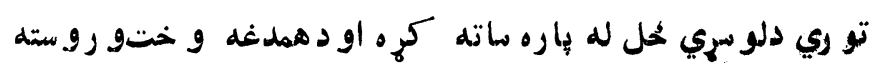

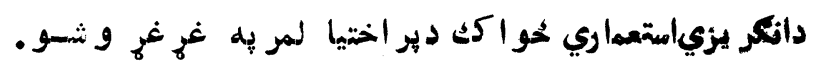

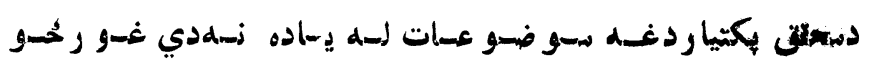

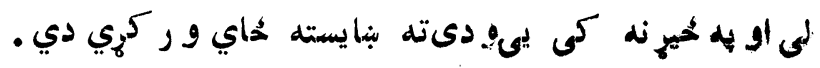

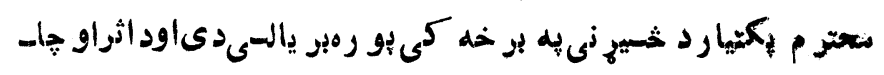
جمهد ليى مم ارزبنمن اوضر و ري كنبل كيبري .

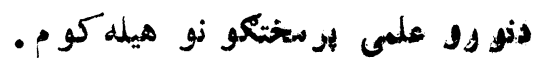
بله درونا و ي

دسر سحققىر ستيا نصر الهه سو يمن منكل

$$
1+90 / r / 9
$$




\section{سر يز ه}

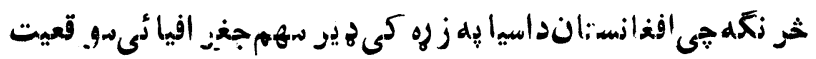
لزياو ددى هيو ادله قلمن و خخه هي يو يلنهى لار ىختيق او. شمال

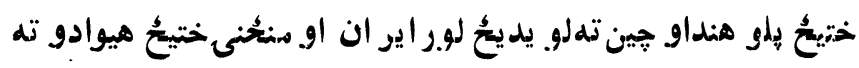

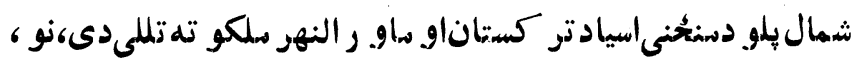

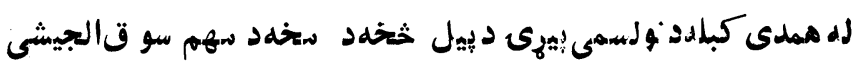

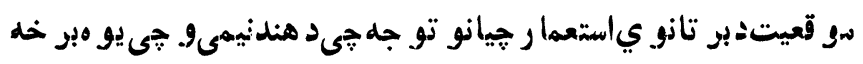

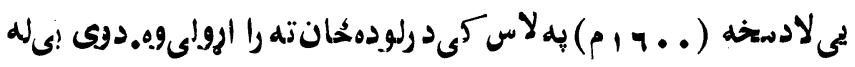

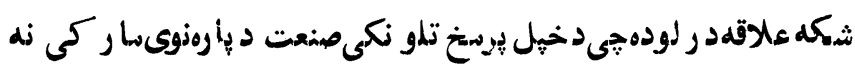
ويدا كرى او خهل زظاسى،سياسى، تجار تى او اقتصادىنفو ذاو قدرت ته بو اختياو ركاندى.د همدغو عو الهلو. يه بِام كى لر لو سر هافغانستان نو سرىداستعمار رى هيو ادو درقابتاو بياور ويتهدبر تانو ياستعهار جيانو دتير ىاو تجاو ز هدف و گر ز يده .

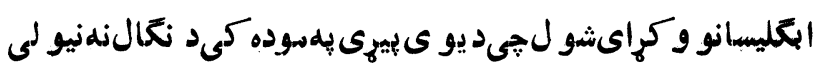
تر بيبنو رهيو ر ى سيمه لاندى كرى. همدر نكَه تز ار ى رو سود

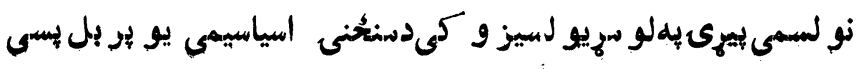




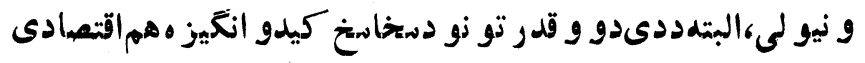

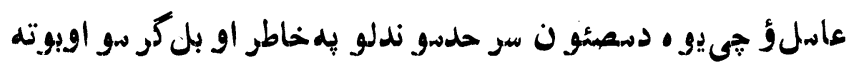

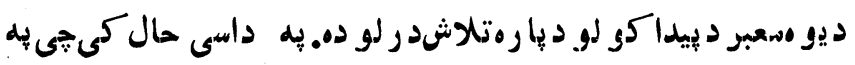

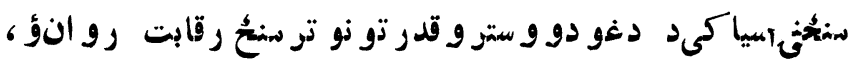

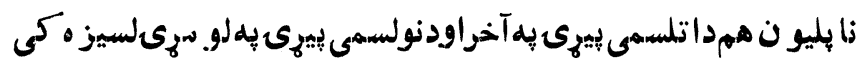

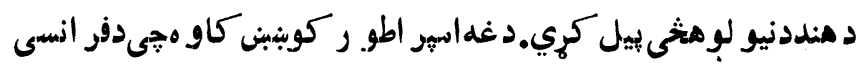
اير ان،افغانستاناو نو رو هيو ادوبه كيهو ندبر تانيى بو ضديو كنفدـ

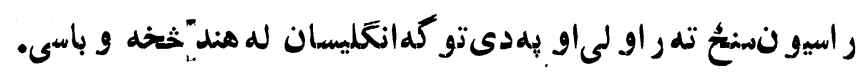

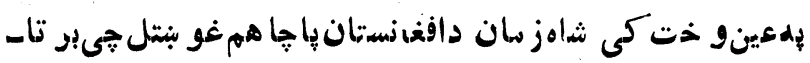
نو ي اشغالكر اند هغهماى دمتحلىد و لتو نو پِه كمكله هند نهلرى

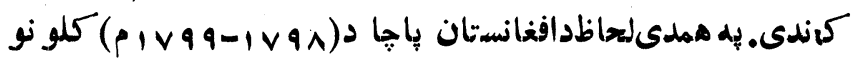

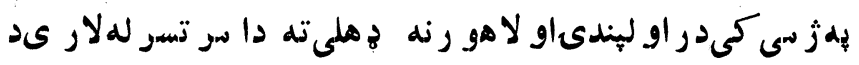
تيار ىنيو لو بهحال كىؤ جیى رته خبر و رسيد جیى داير انياجاد انكليسانو به تتحر يك بِهخر اسان اندى تير ى كرى دىاو هر اتئىتر تهد يدلاندى

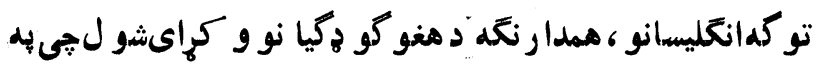

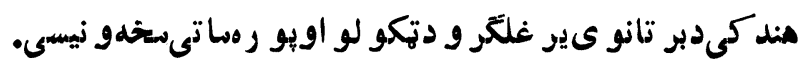

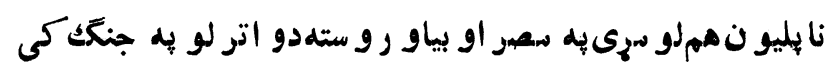

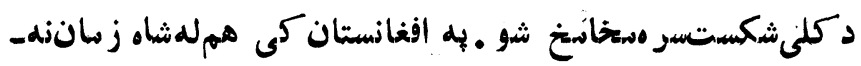
و رو ستهددر انيانودعظمتدووره بايىته و ر.سيده. او بهنينحني اسياكى 
دأرو بائى هيو ادو دلاسو هنى اؤسياسى فعاليتو. ز نييههبر أبر هشوه. بنجابجى تر دىو خت إو ر ى دافغانستان بيدقبضه كىؤ .دافغانستان

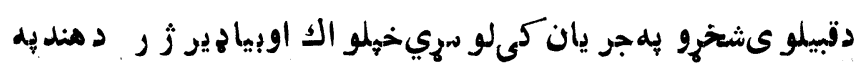

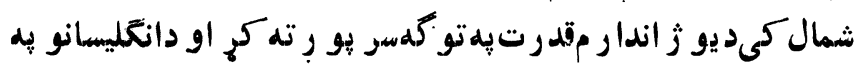

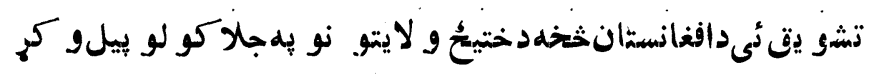

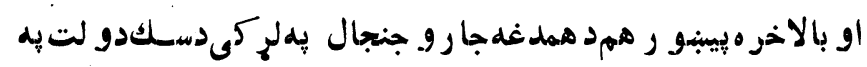

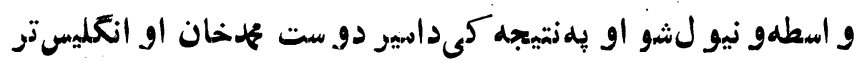

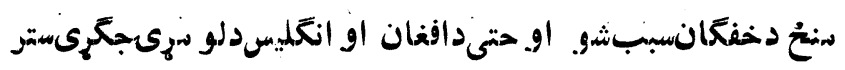

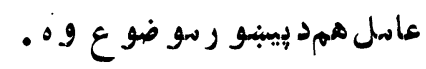

تز ار فر و س همو ختناو ختاير اندهر اتنيو لو ته تشو يق

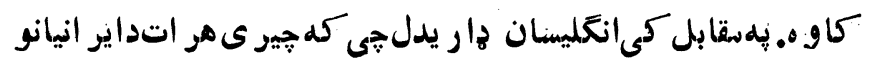

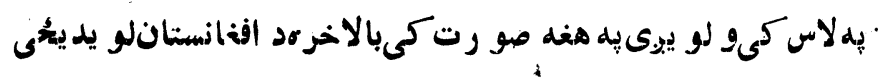

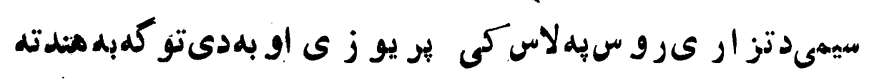

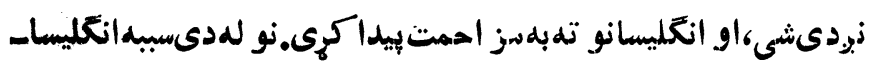

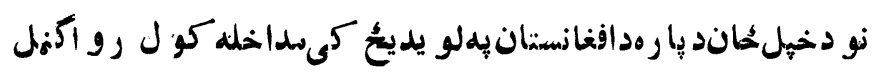

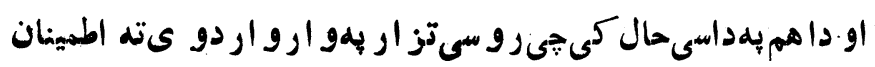

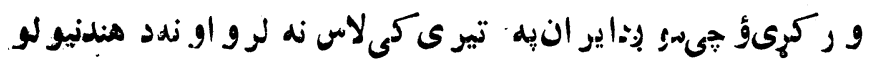
ار ادهر اسره شته .

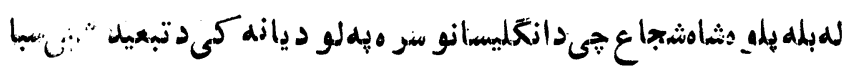

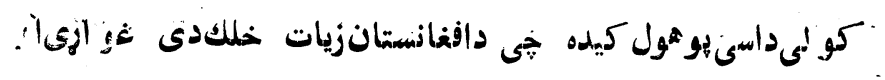




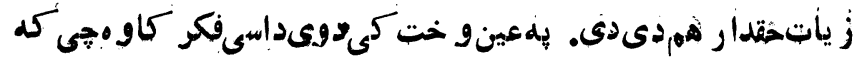

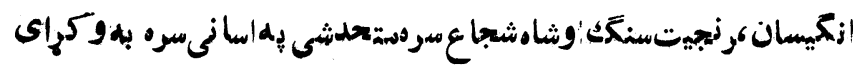

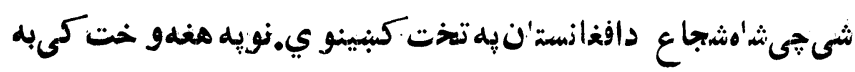

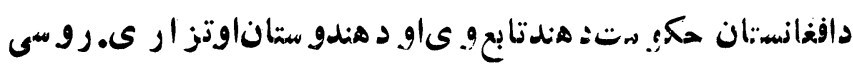

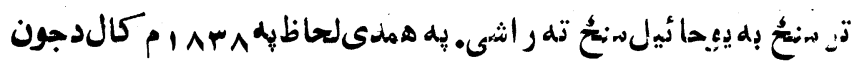

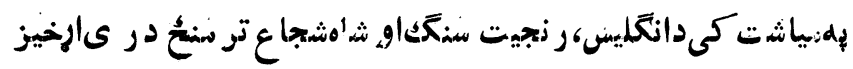

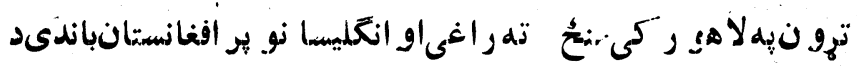

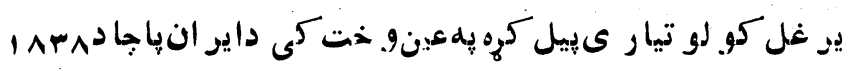

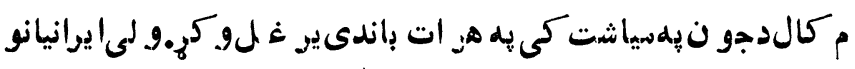

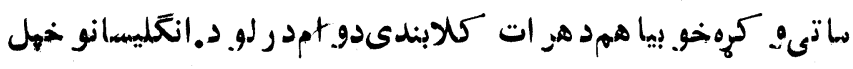

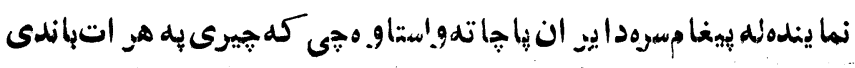

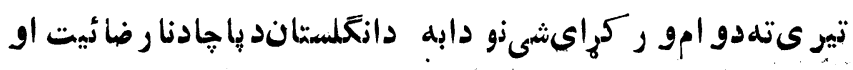

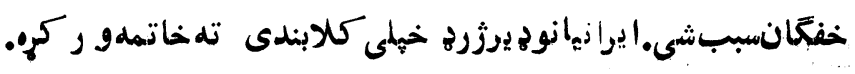

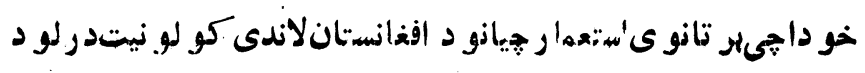

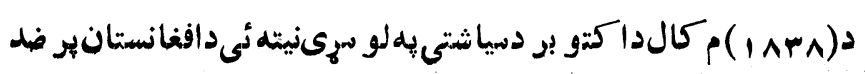

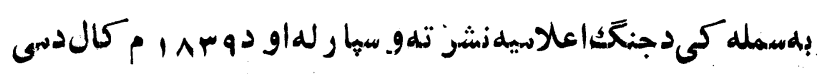

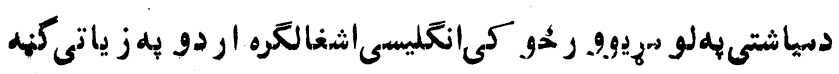

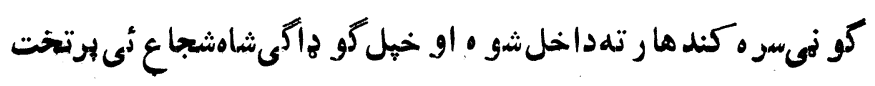

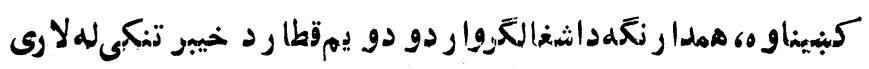




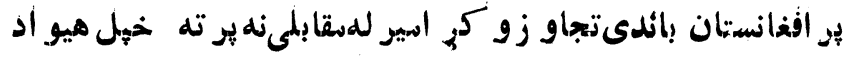

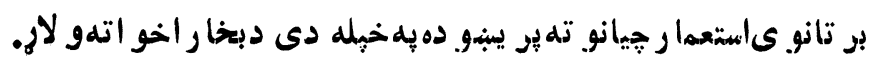

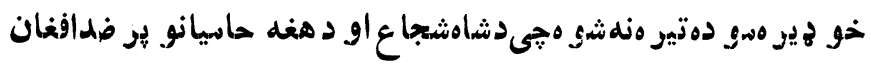

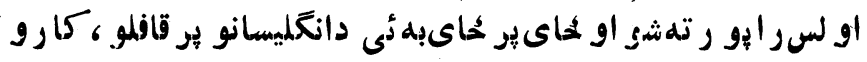

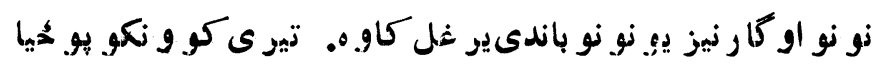

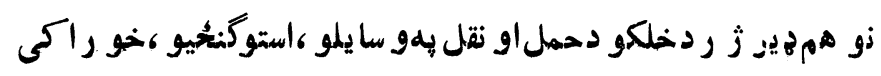

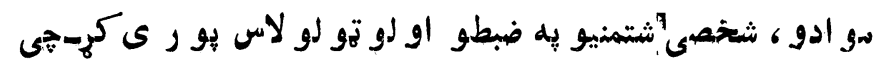

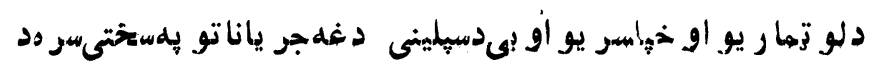

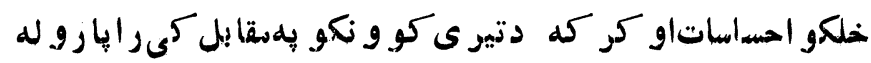

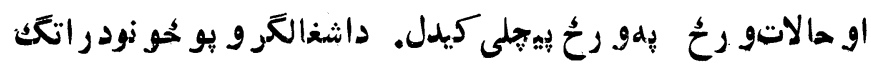

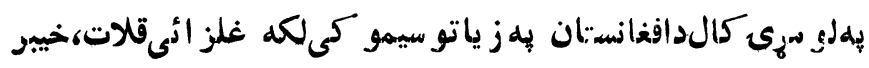

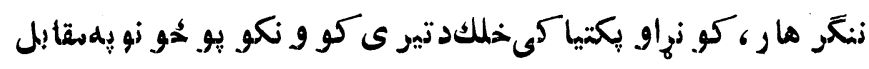

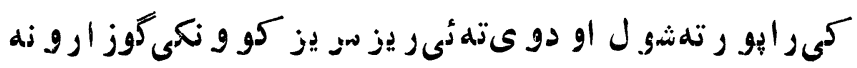

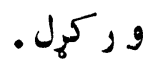

يه ـ به ا م كال كى بيا هم دغغلز ائىقلات خلكو. دتير ى كو و نكو

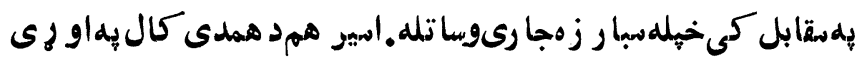

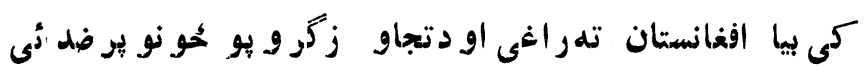

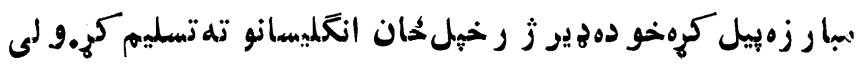

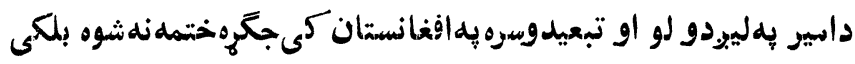

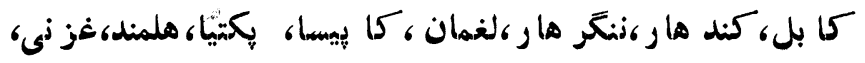




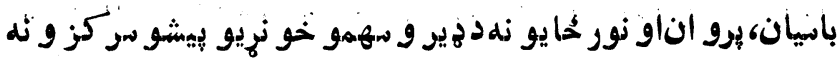

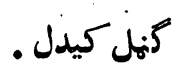

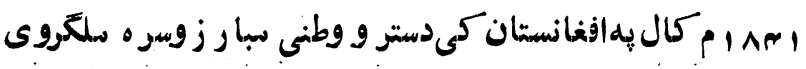

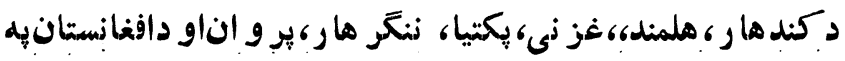
> نو رو.سيمو كى خلكدال نكليسانو بر ضدر او لإيثو ل. يه كابل كى هم

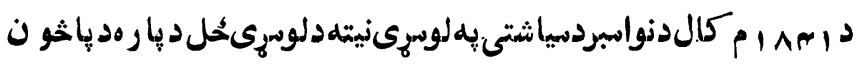
طرحتو تيباه دج:كى اوسولى به خاطر يو هشو ر اتشكيل شو ه. يو ه

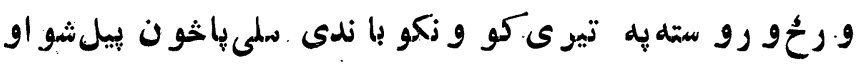

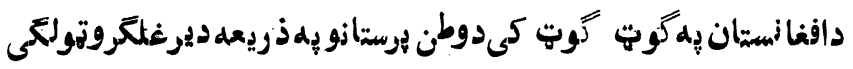

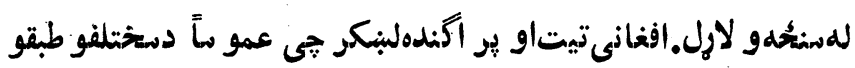

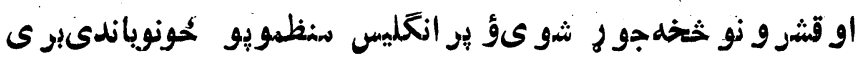

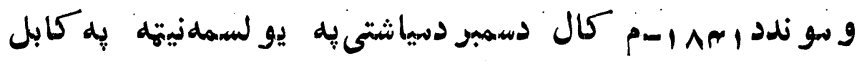

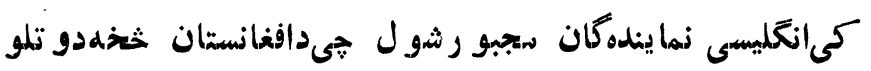

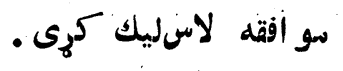

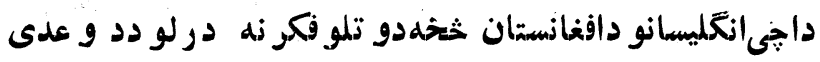
ماتو لو بهخيال كىشو لاو به هغهاو دنهو خت تيو او مجىدو ى

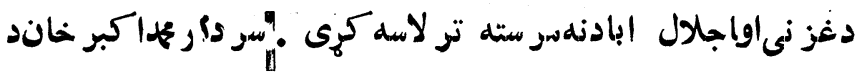

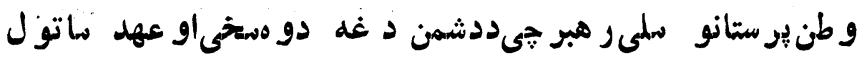

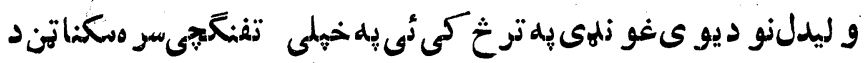


بر تانيىسياسىنما ينده و و ازماشغالكر و ددىعمدهالهام بخبنو و نكى و زٔ نى بهذ ريعه يه كلى تو گهخخيله رو حيه بايلوده او جنر ال الفنستن

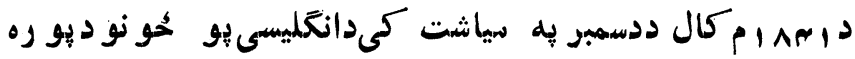
تسليميدو او و سلىو ركو لو او ديبنبو رله لار ىبو تا نو ى هندتهد

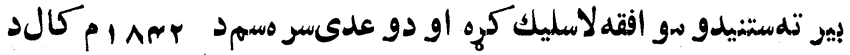

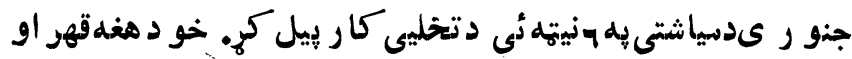

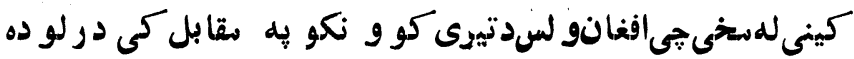

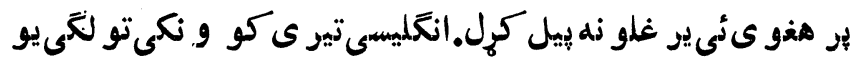

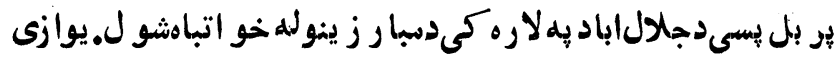
سر دار محماكبر خاندافغاناو لسمشروكرايىشول جِى جنر الالفنستن او د هغو ى يو خو فاسيلو نه رو غ ر متججلال بإدتهو رسو ىدنو رو

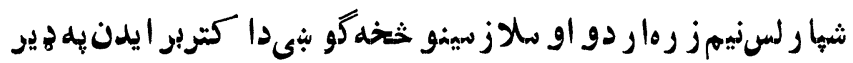
بدحالجلال إبادتهورسيداو جنر السيل ته نى دانكليسسىار دو دتبا هى

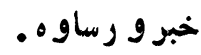

دو ستمُحخانجى لاتر او سهد تبعيد بِهحال كى ؤ دبر تانو ي هند كو رزو جنر اللار دايلنبر و لهخو اكلكشى تلهو غو بنتل شو .دخبر و

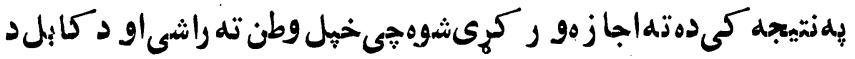
سلطنت ير تخت كنبينىخو يهدى شر ط جىو ز يو مها كبر خاندملى 
2.2

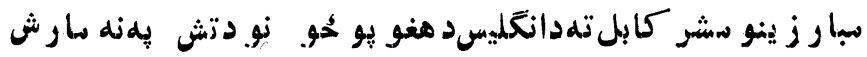

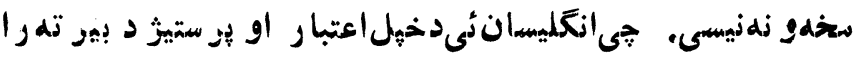

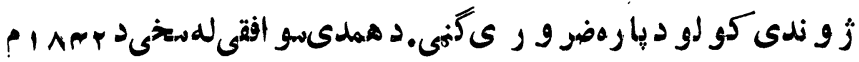

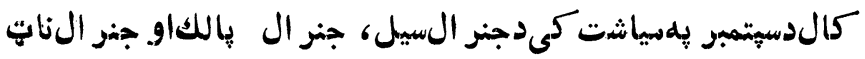

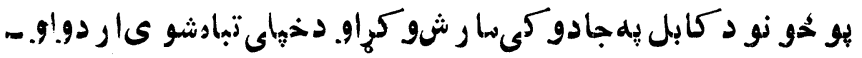

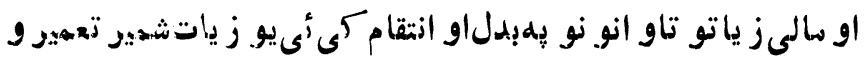

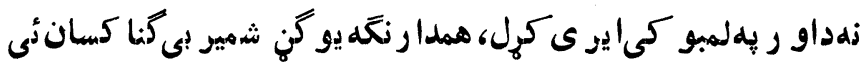

دتيغ خخه تير كرل. خو داجىتير ى كو ونكو. ته الهام بخنبو و نكى

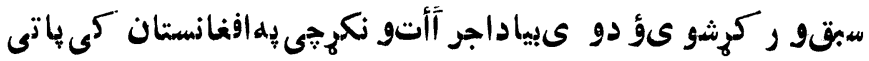

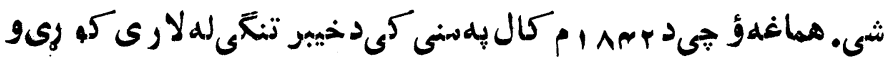

ز ز رافغانستانخخهو و تل

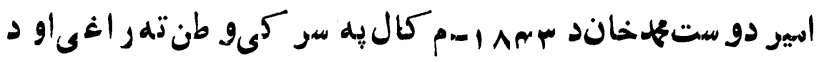

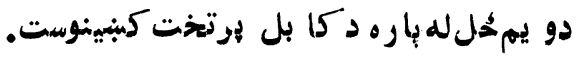




\section{لومزئ فصل}

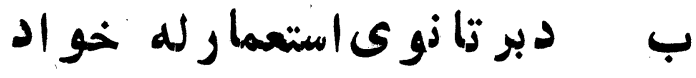 افغا زمستان د نهو لو عو الهل :}

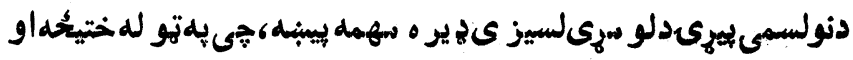

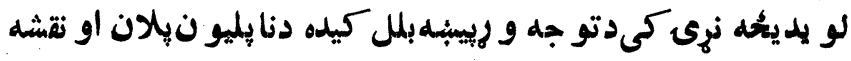

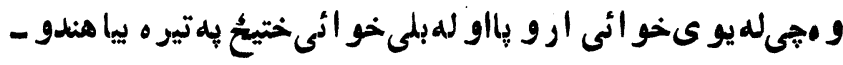

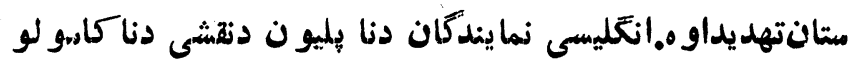

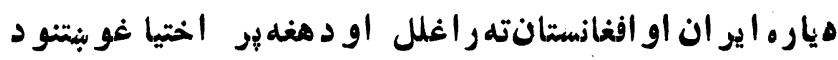
دسيسو دخثنى كو لو دباره لازمثدييرو نهو نيول شولن.

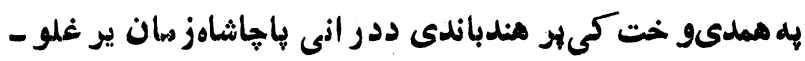

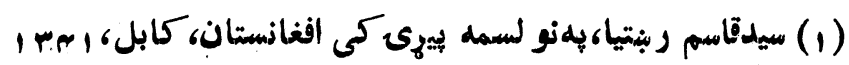

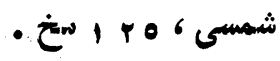


ذهددىسببشو لجیى بر تانو ى انهير اتو ر ى و اكمنو تو جلد

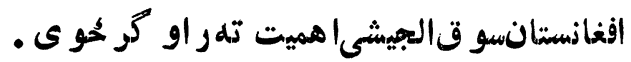

بر سير ه يو دىتز ار ى رو سيناو فر انسهدو الره الستعمار ى هيوا

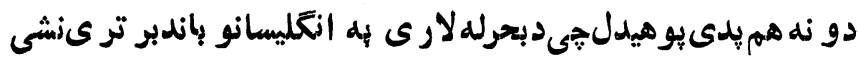

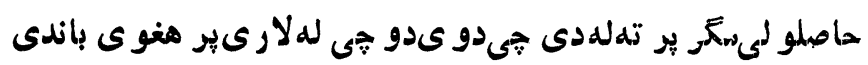

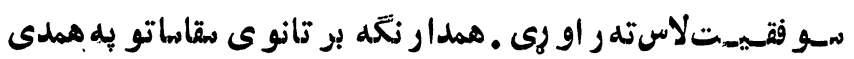

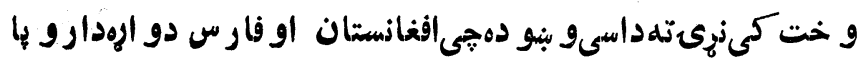

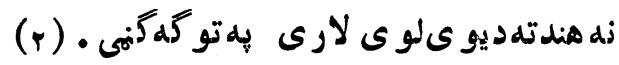
بهافغانستان كى دانكليسانو سياست دنايليو ن تر قطعىهاتى بو -

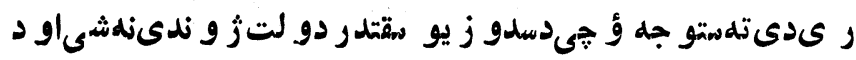

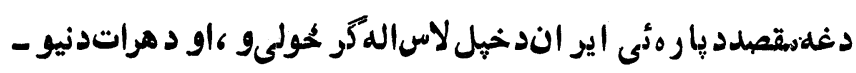

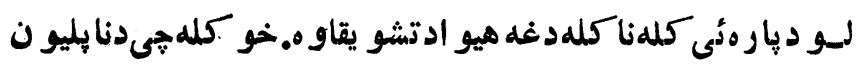

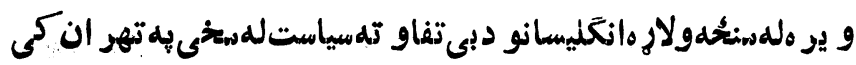
خبل نفو ذلهلاسه و ركه او تز ار ى روس دتو كما زيجى تسرون

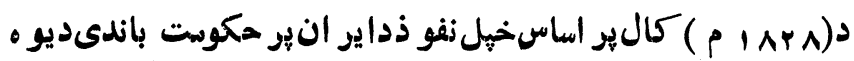

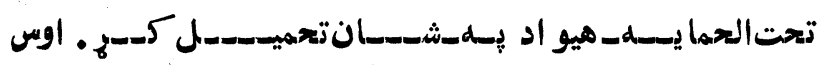
نو هراتبيادتز ارى روس به تحريككدايرانيانويهواسطة تهديديده.(ب)له

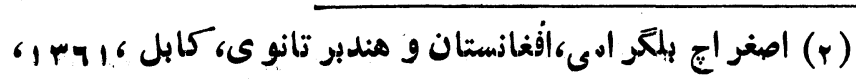

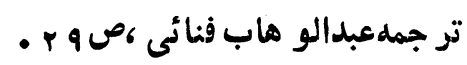

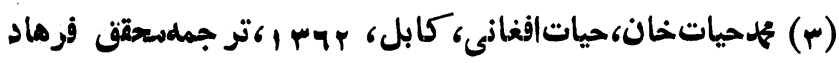
ظر يفى او دحقق عبداللطيفطالبى6 وس 1 - و ه 1 هيخو زه . 
همدىو ختو رو ستهدبر تانيى سياست أفغا نستان او ايرا ن إله

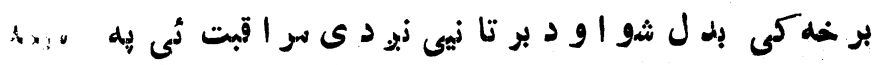

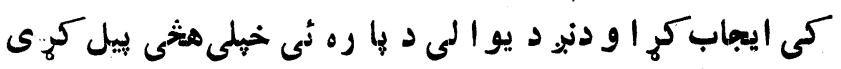

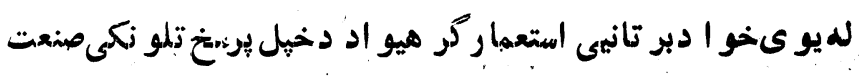

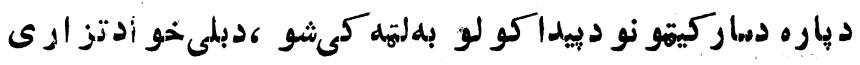

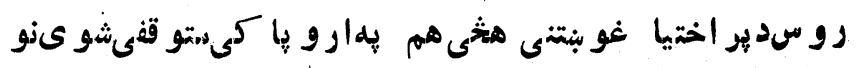

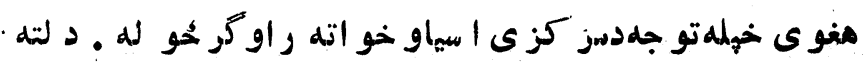

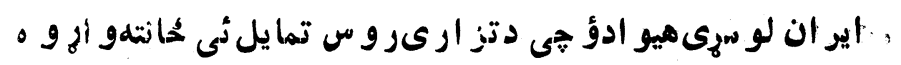

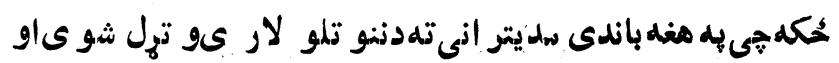

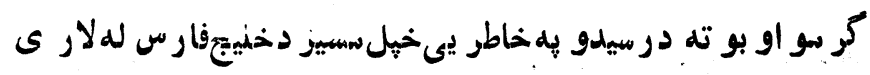

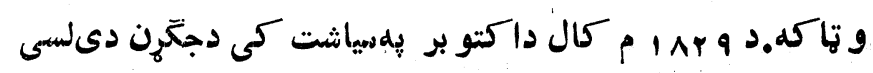

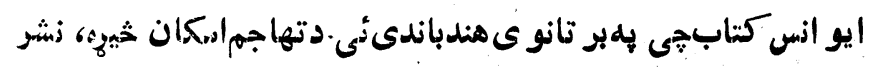
شو •مؤ لفيلهذغه كتابكى دتز ار ى رو سترهاجمته دافغاذستان

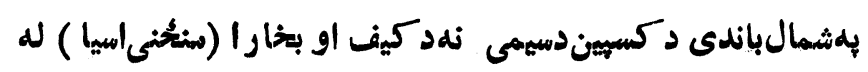

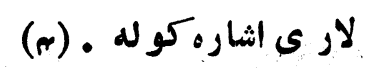

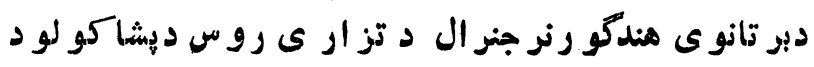
بار مديميسو بو ره صلاحيت د رلود خو دتها جم او لبيكر كشى ملاحيت ئى دلندنداجاز ى ير تهنهدرلو ده.دد هلو سزى اقدامداو ه هیى كيتان كانولى Capt. Cannoly او الكسشاندر بر نسئى

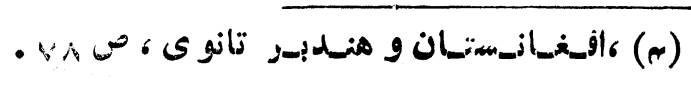




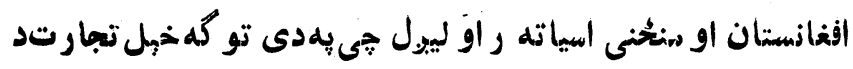

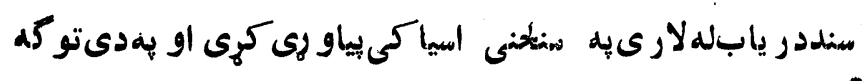

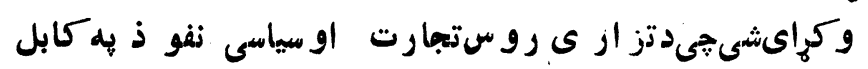

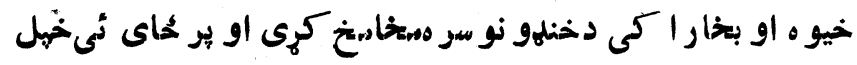

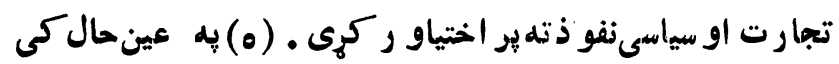

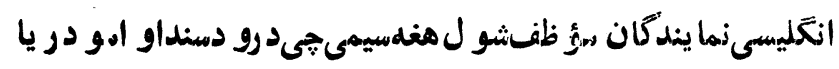

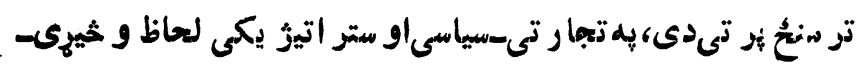

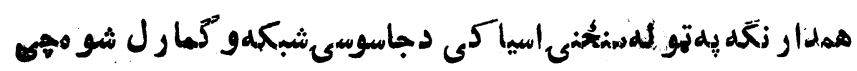

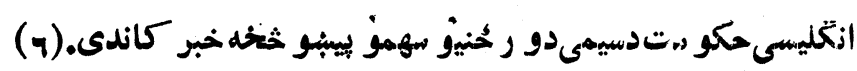

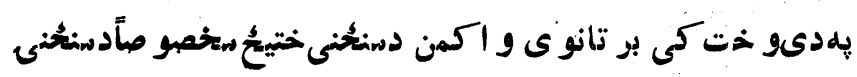

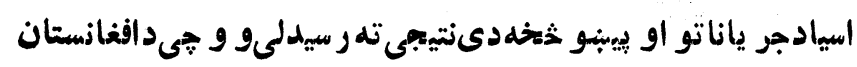

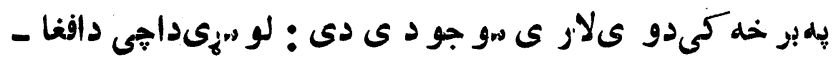

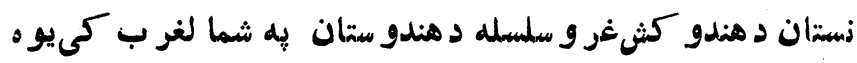

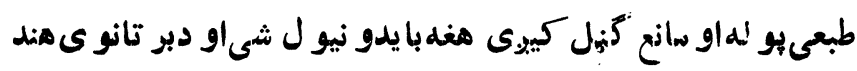

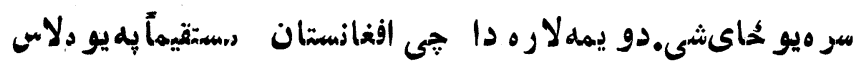
(v). لاندى هيو اد بدلثنى

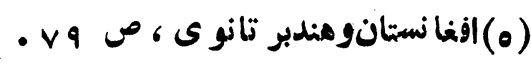

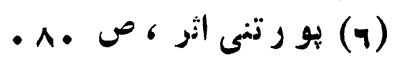

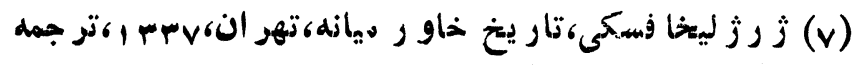

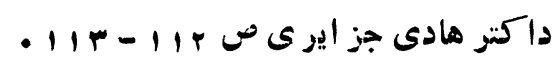




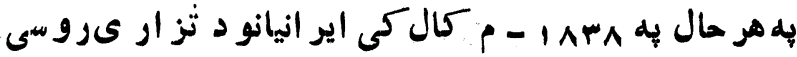

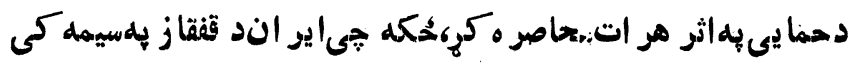

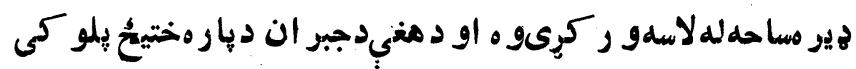

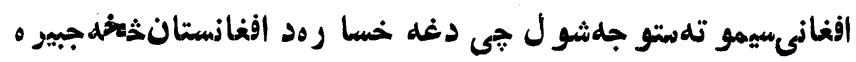

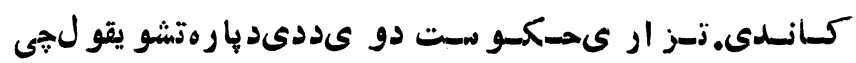

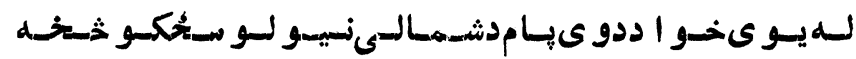
و ارو ى،لمبلى خو ايه هر ات باندى داير انيانو دتسلط به صو ر ت

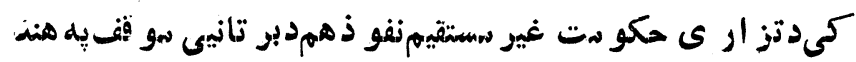

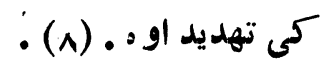

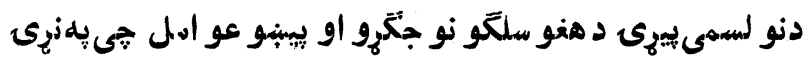

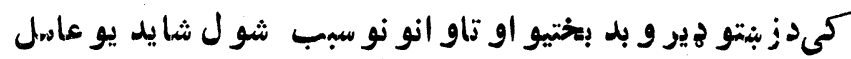

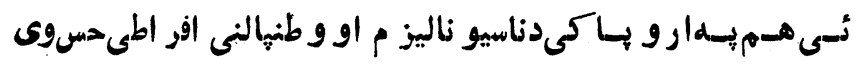

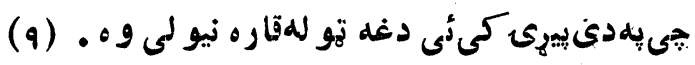

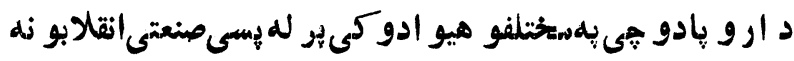

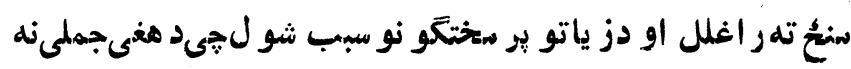

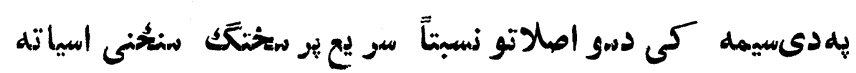

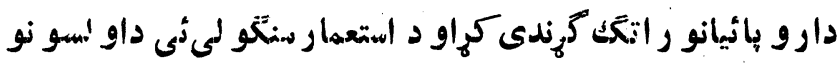
يهكر يو انو كى و رخبنى كرى .

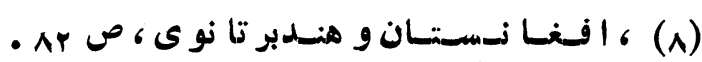

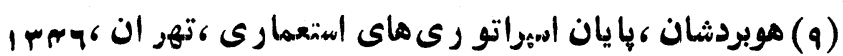

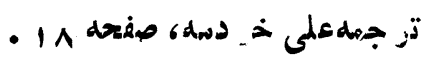




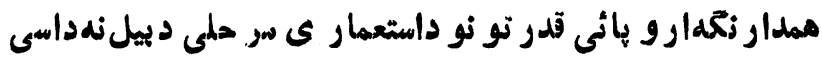

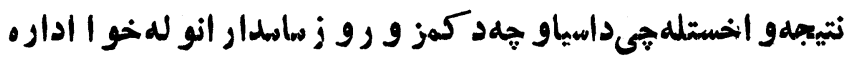
كيي،ىنو بهدى توكهدو ى

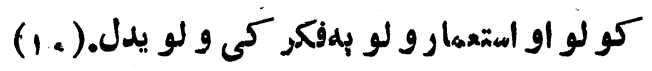

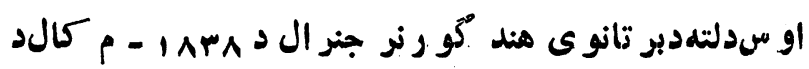

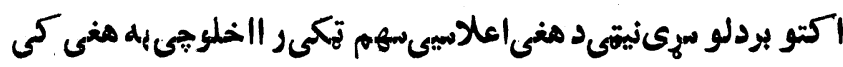

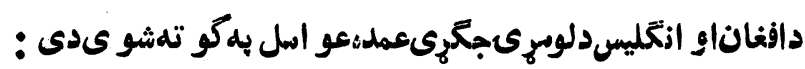

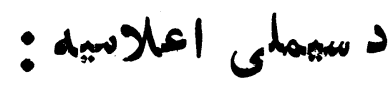

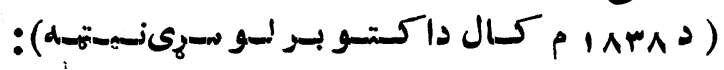

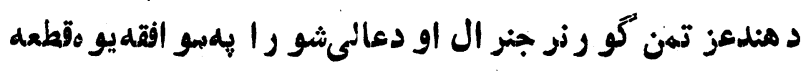
بو تانو قى قو ادخدست بهمنظظو ردسندد رياب بهاوبهدو كى ددهدعالى

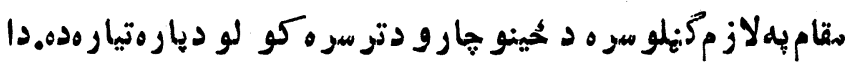
يو بنكار : حقيقتدى:ى د دrی 1 ام كال ترو ن دبر تأنيى حكو مست لهخو ا دسندادير دبهاو 'يو رنواب او.تهار اجه رنجيت سنككتر منئ دسنديهدر ياب كى دكشتير إنىدير ا نستلو او د هغd دتضميند

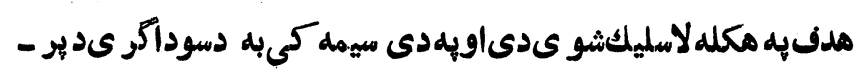

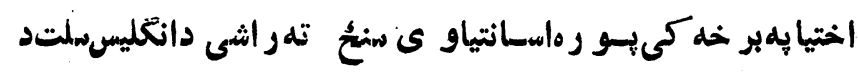

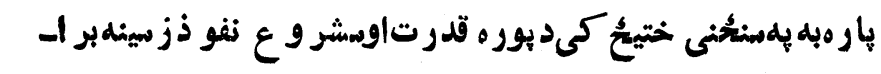

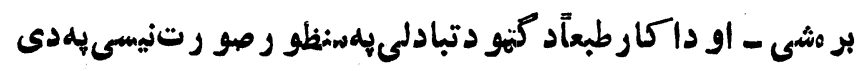

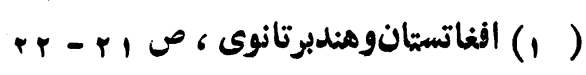




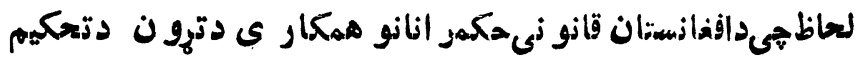

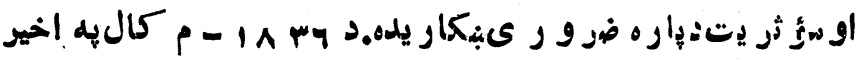

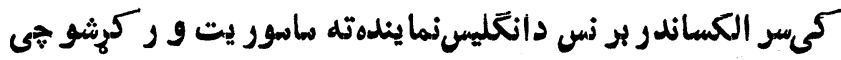

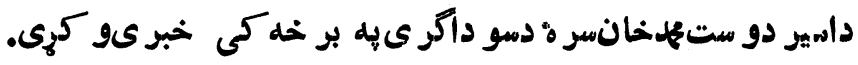

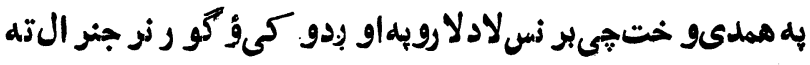

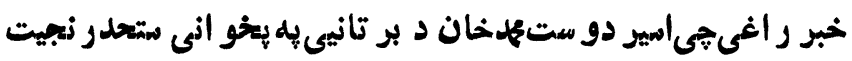

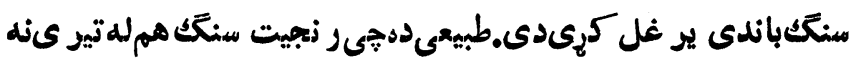
ددفاع لهياره سو لهidده كيى،خو بيا همدا هارمو جو د دى هيى

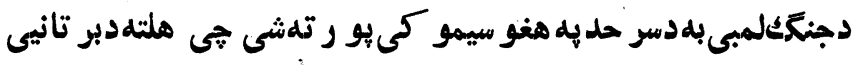
دسو دأك ى دير اختياد باره توقع مو جو دهده .

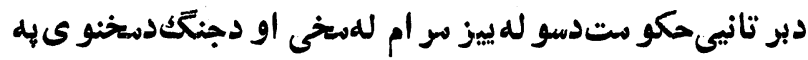
خاطر تضميمو نيو جى بر نسدادير دو ستمخاخان سو هدوغو جار ى

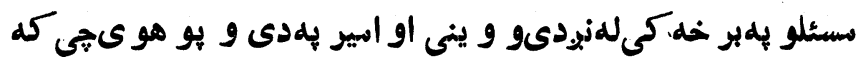
جيرى دسو لى لاره و نيسىدبر تانيى حكو متبهد دو ى دو ارو تر ننغ تو لى مسئلى ددو ستىلهلار ى حل كرى مها ر اجهر نجيتسنك

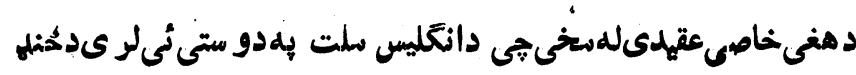
ير تهئى دكو ر نر جنر ال بهلبيشنهادو نو باندى ر ضائيت و بنو ده ـ دكو ر نر جنر البهعقيده داير انبانو تير ى بهلهـر ات بـا نـدى -

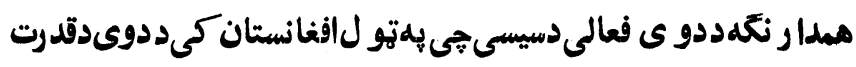
او نفو ذ دبر اختياله باروهرو انى دىحتى درو د سندنه اديخو اهم 
دتير ى فكر لر ى.اير انيانو زه يو از ى دبر تانيى دنما يندكى سفيي

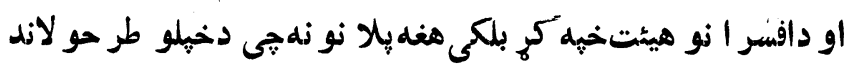
ئىنيو لى دىدلو ىبر تانيى هغو تو لو اتحادى يو نسيبو نو نبر خلكاف دى جى دبر تانيلسو:مئى لرى .

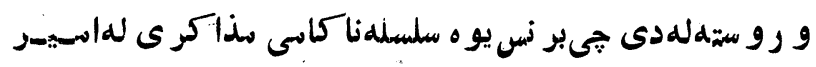
سره توسره كريىنبكار رشو هجى امير دايران بِه تشو يق دسهار اجه

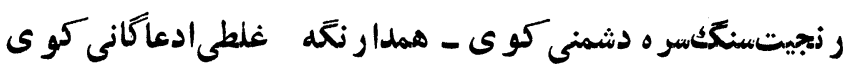

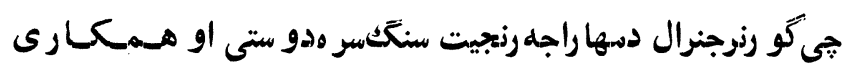
لرى. بوسيوه بر دىاسيو دخبلو خمكو دير اخو لو نيتاو نطالسبى

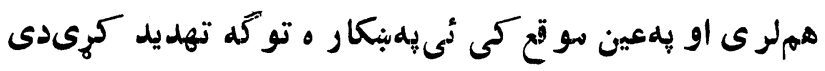
جى دخهيلو يلانو نو او طو حو ديلى كولو ديا ره جیى هوخوسر ه بازدينيو

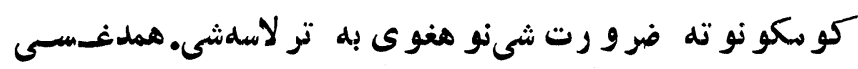
اسير داير اند نقشو اوطر حو نه به افغانستان كىى حما يت كوى جى داغير دو ستانهمل دبر تانوى هندديمتو بر خلافدى او بر تانوى

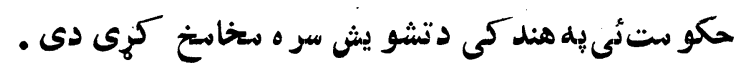

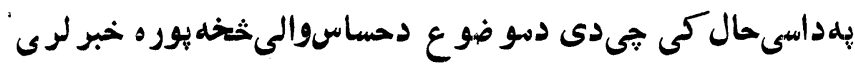

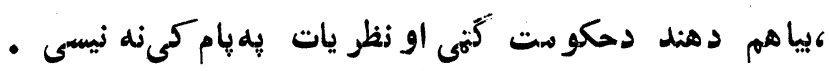
دخكىلهدى جيىدبر نس دهامو ر يت هدفو زهتر سو هشى-دى ميجبو ر

$$
\text { شو جيى كابل بر يبو دى . }
$$

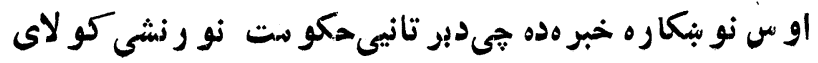




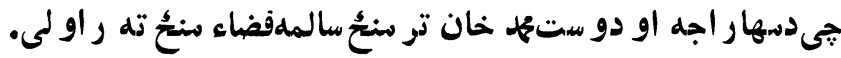

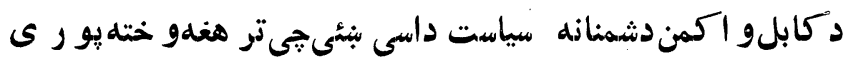

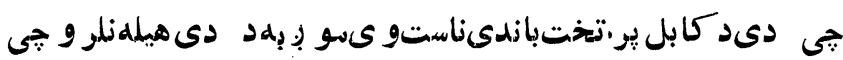

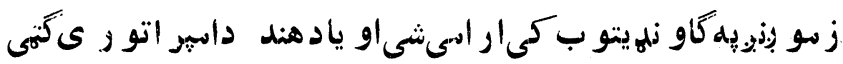

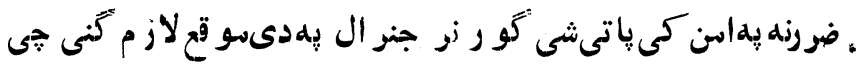

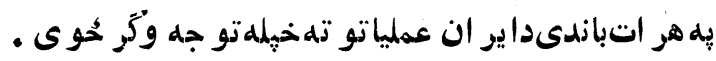
د خو بياشتو راهيسى يلهغلنبار كي دايز ان عدلياتجار ىدى

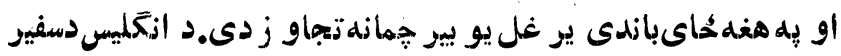

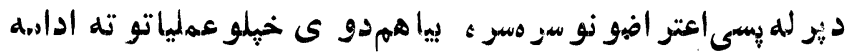

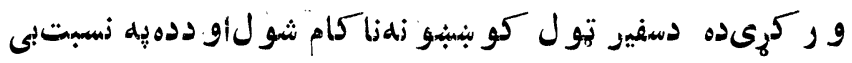

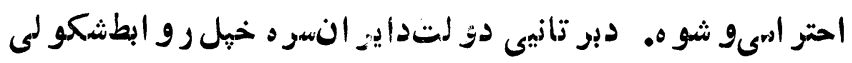

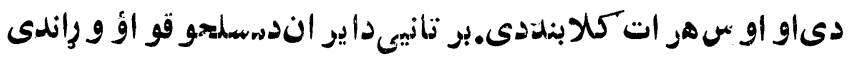

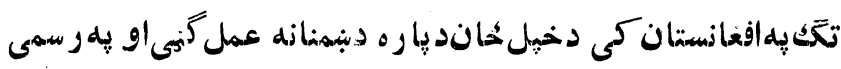

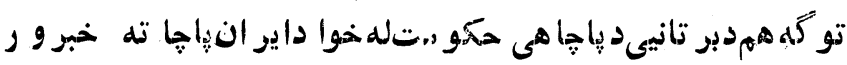

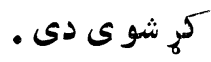

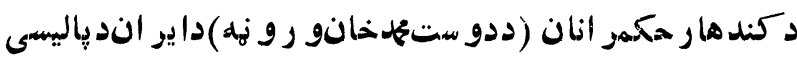

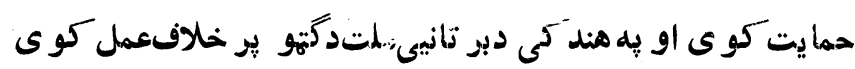

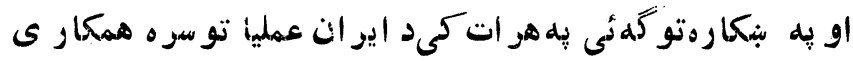

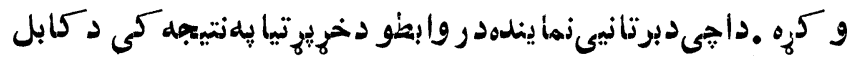

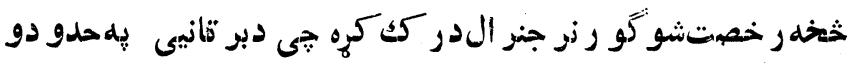
باندى دخار جى دسيسو أو تير يو ددريخنيو ىديا ره لازم تدبير و نه 
و نيسى .دبار كز عسر دار انو خخهجيى حكمو دت ئى دسل و ز يونه

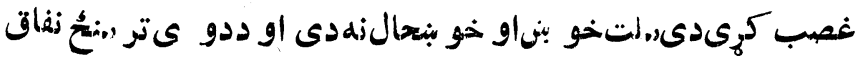

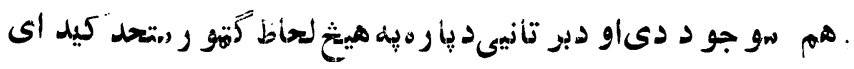

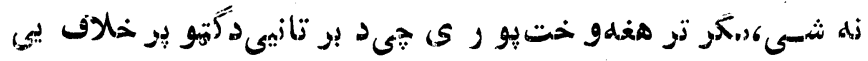

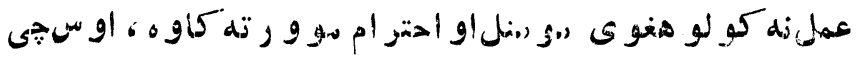

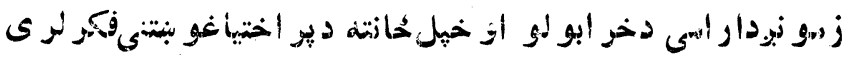

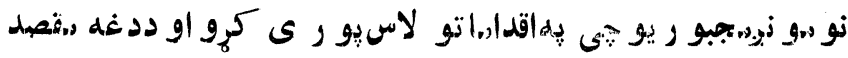

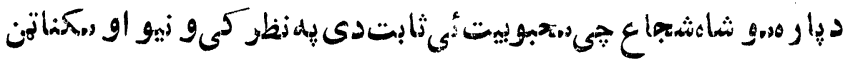

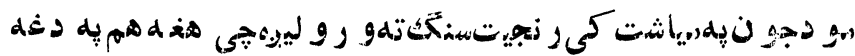

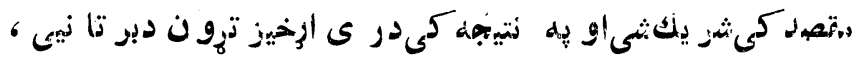

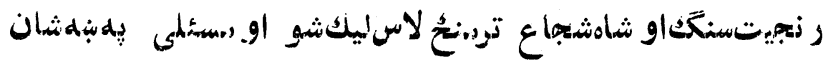
حلى شوى .

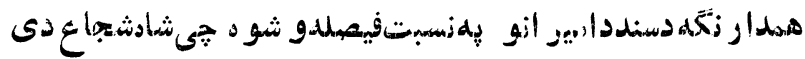

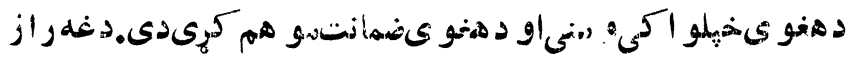
دهر ات او د هغdدخيلو اكلى بيهنسبت هممفيعهله او ضمانت شو ىدى.

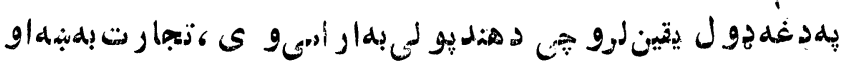

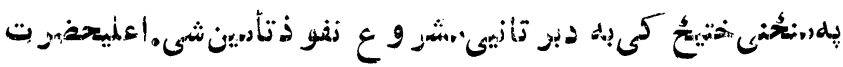

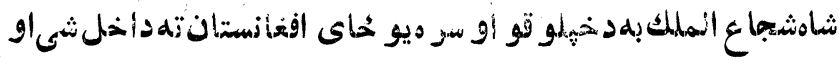

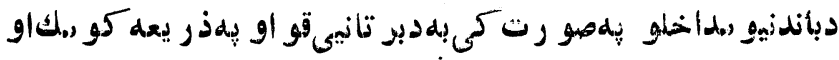
او حما يه كييرى . 


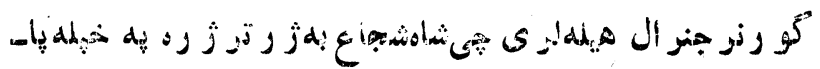

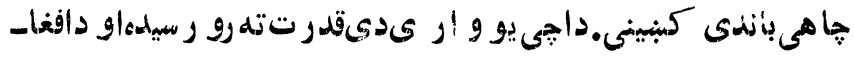
نستان از ادى او نداريت برقو ارهشى اله هغلهو رو سته بلهبر نانوى

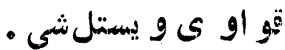

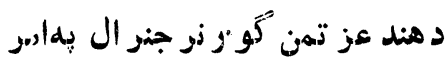

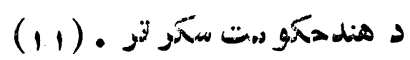

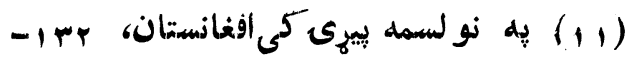

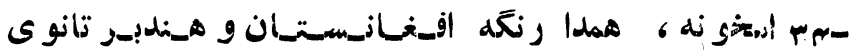

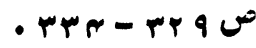




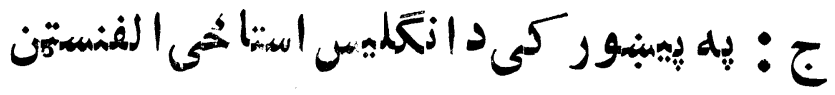

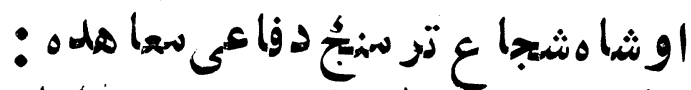

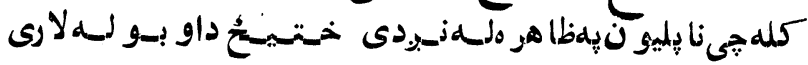

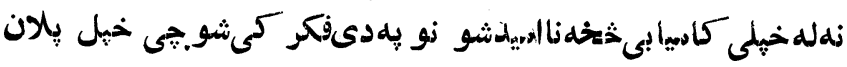

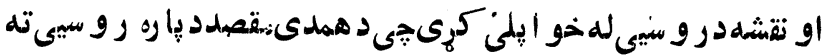

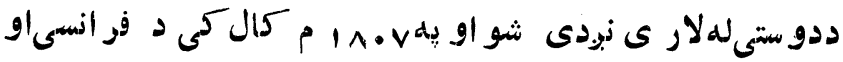

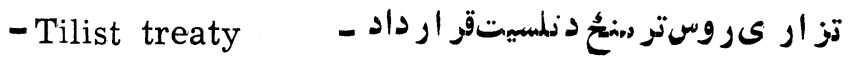

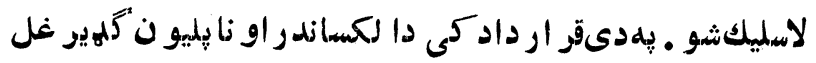

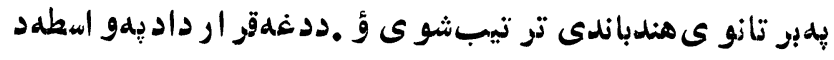

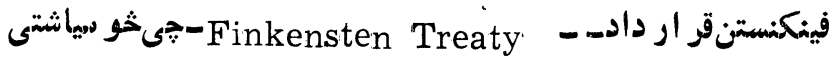

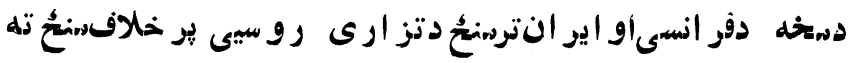

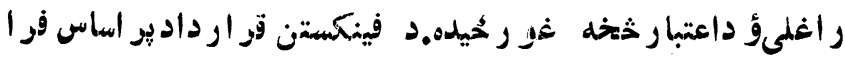

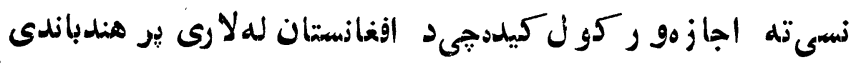

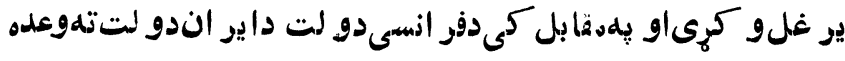

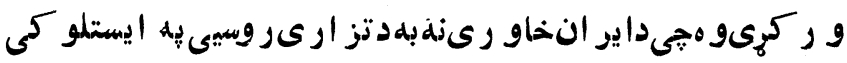

$$
\text { همكار ى كوى . (ir) }
$$

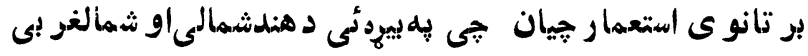

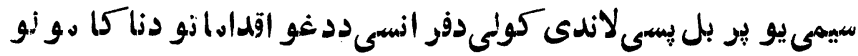

Gregorian, Vartan,! The Emerger.ce of Modern(ir) Afghanistan, California 1969, P.94. 


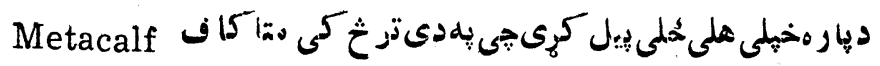

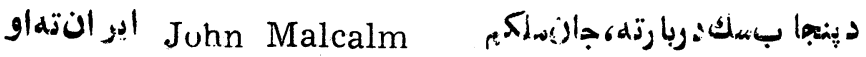

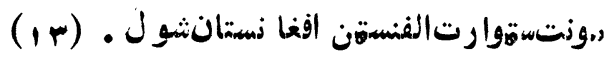

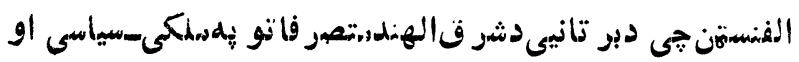

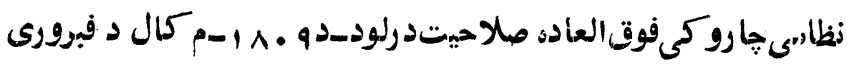

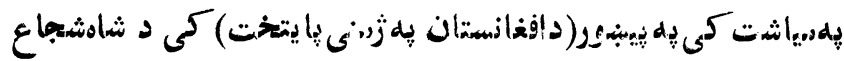

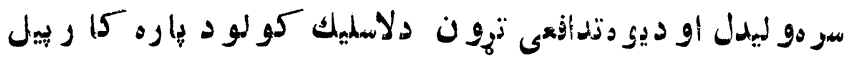

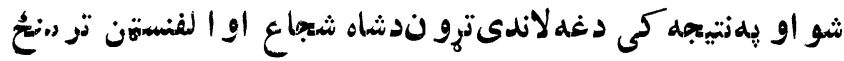

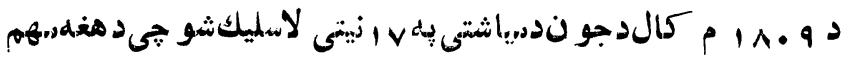

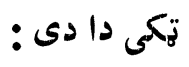

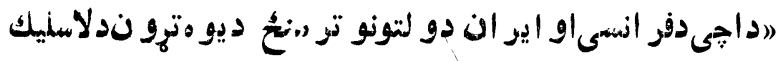

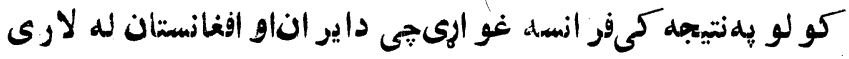

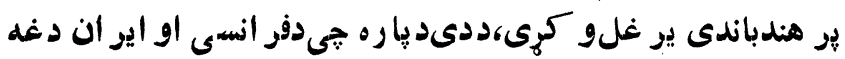

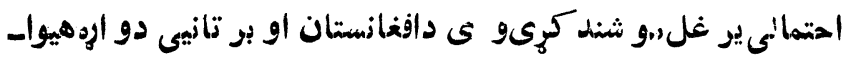

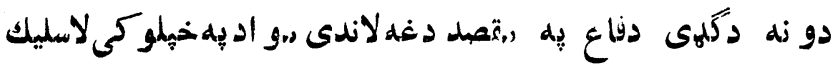

كوى :

| ـ داجيى دفر انسى او ايران دولتونو د كأبل بر خلاف يو فر ار دادلاسليك كرى دىنو كلجير دى دو ى و غو ارئى دافغابستان

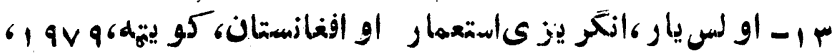

. di

$-1 r-$ 


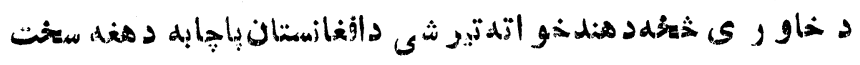

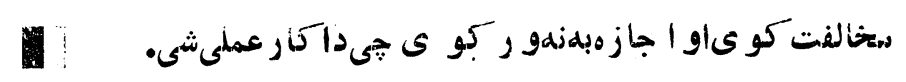

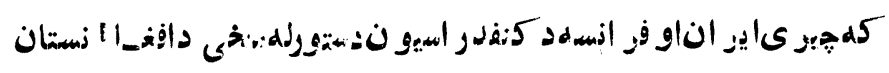

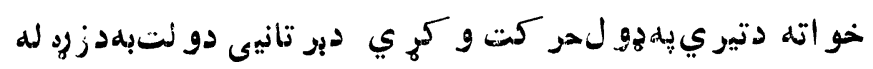

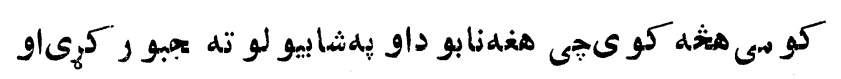

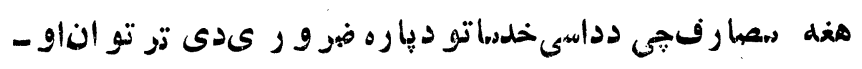

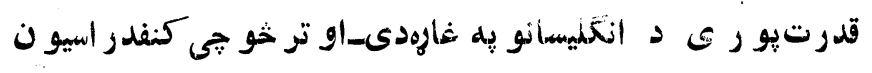

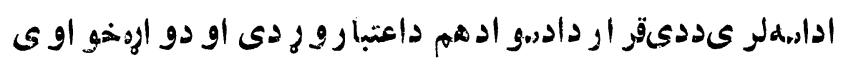

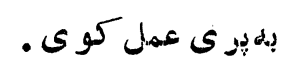

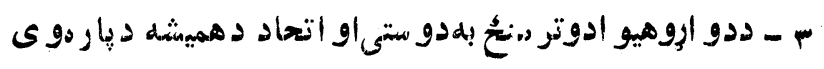
يودو لت به د دبل دو لت بيه كو رنيو جا و وكى ميداخلهنه كوى او دافغا

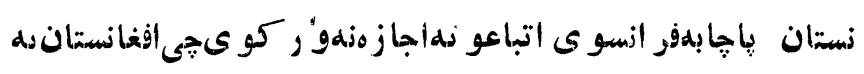

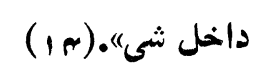

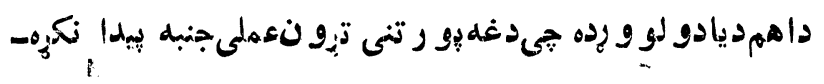

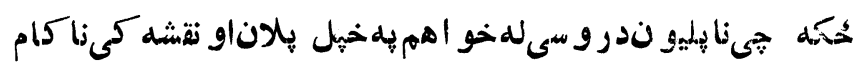

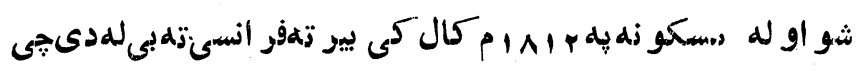

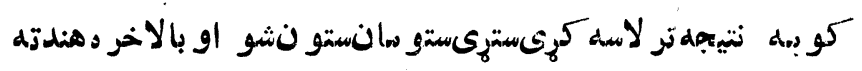

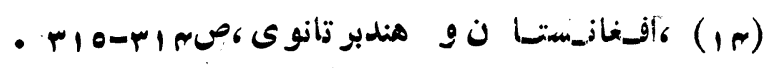


در سيدو خو باو خيالنى يله 11 1 -م كال دو اتر لو يه و روستى

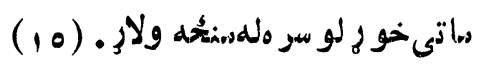

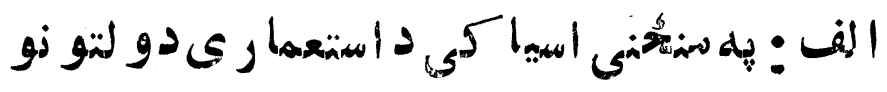

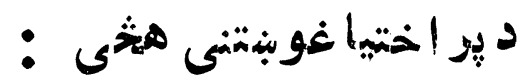

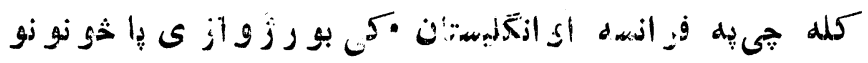

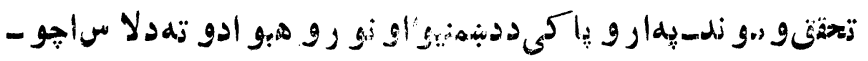

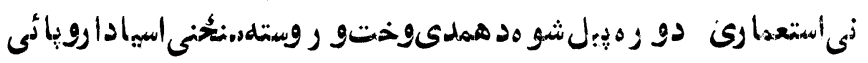

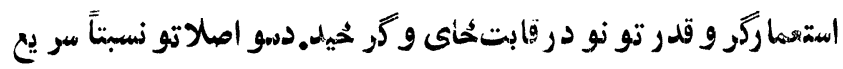

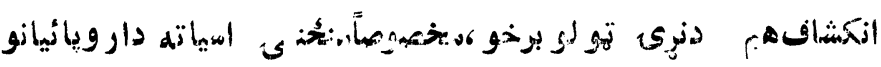

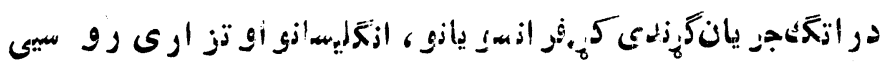

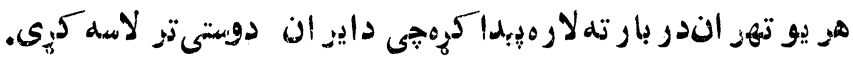

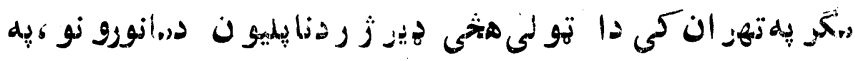

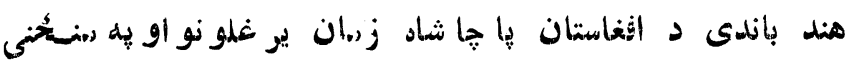

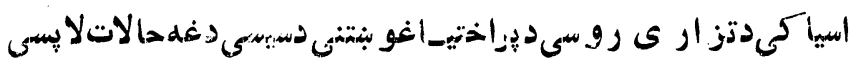

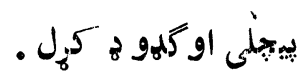

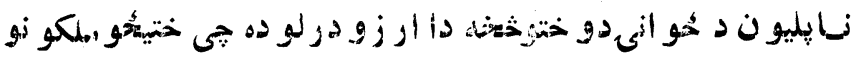

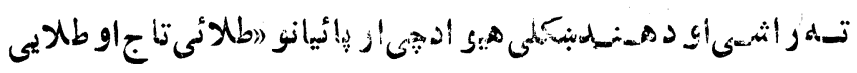

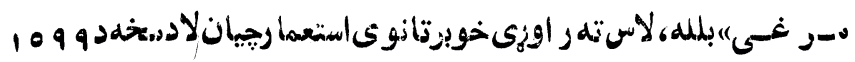

Louis Dupree, Afghanistan, New jersey, (10) 1973 P. 363. 


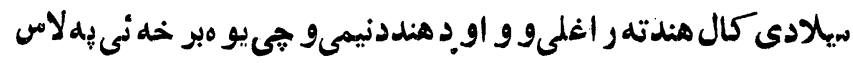

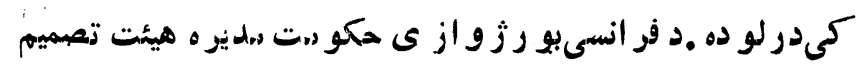

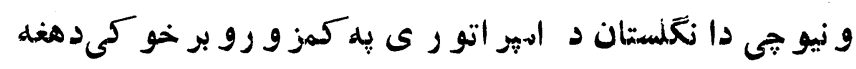

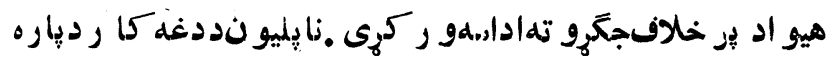

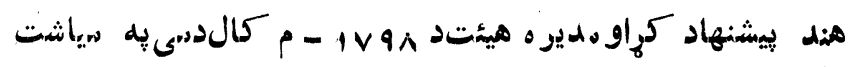

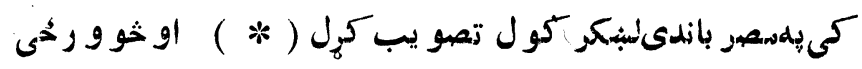

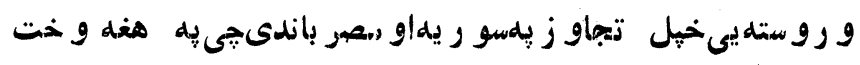

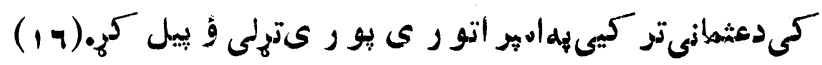

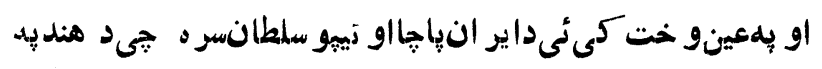

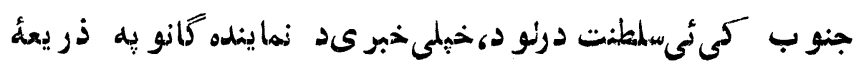

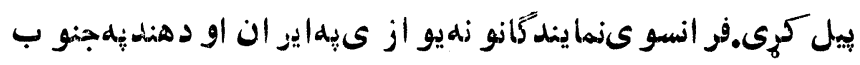

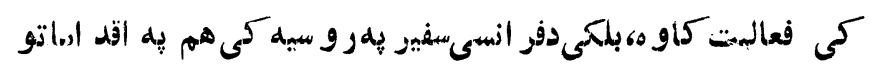

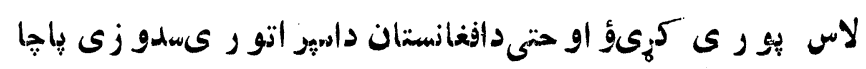

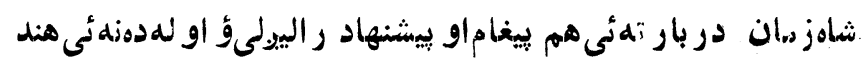

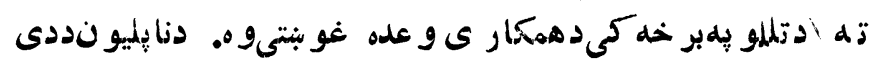

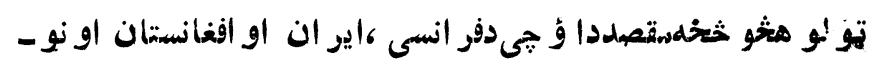

و - نابيليو ن بهو يل : هوخو كتجى ددصر و اكدارشى - دهند و اكدار هم دى.

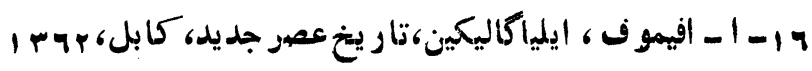

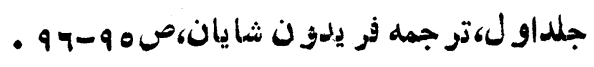




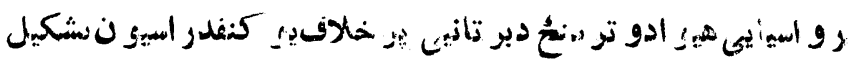

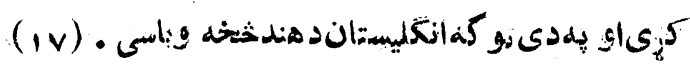

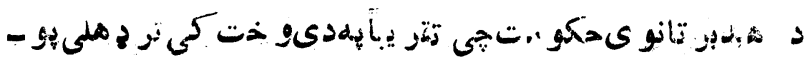

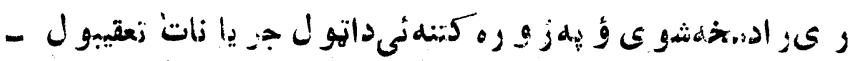

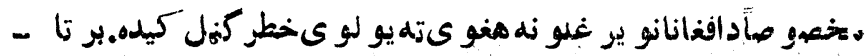

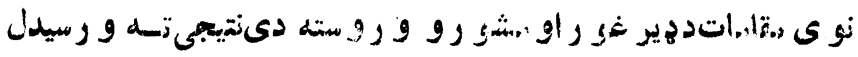

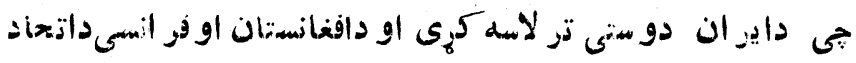

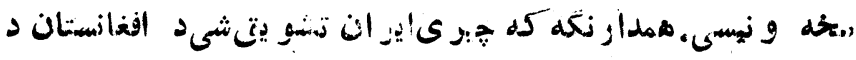

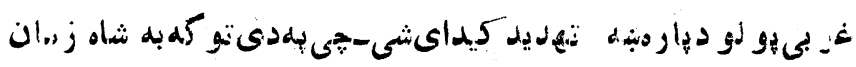

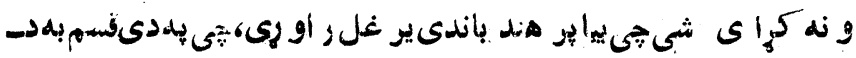

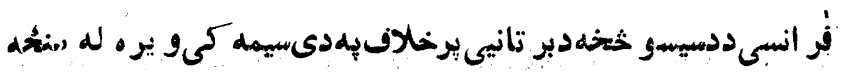

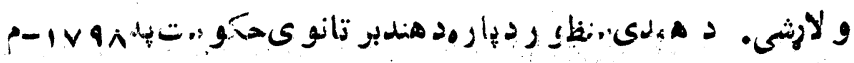

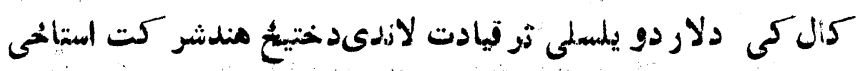

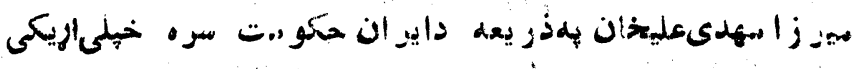

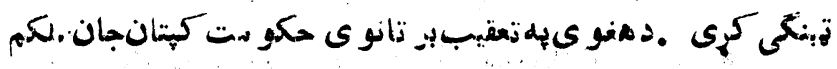

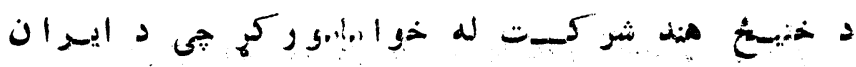

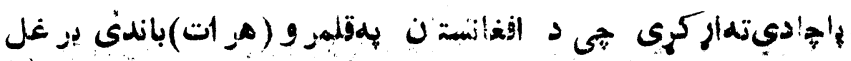

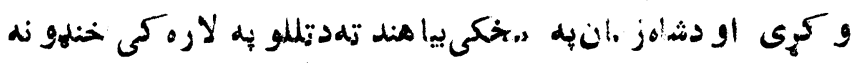

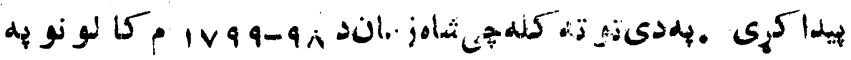

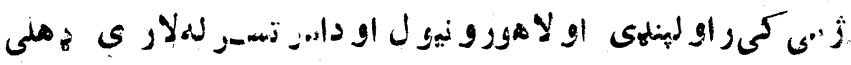

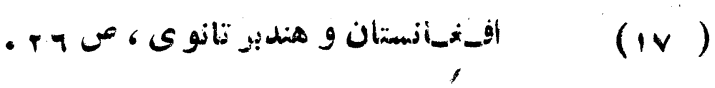


نهدتيار ى نيولو بهحال كى ؤو رتهخـبرو رسيديهنتحعـنىشاهد اير انياجا بِهخر اسانباندى بر يدكرى،او مر اتتر تهديدلاندىدى

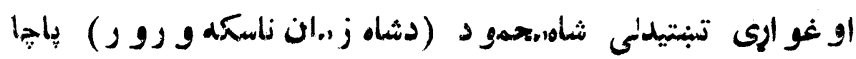

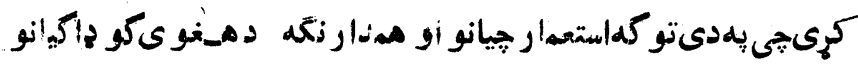

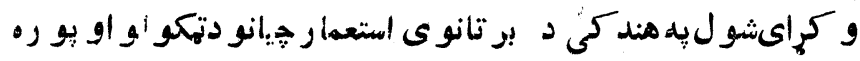

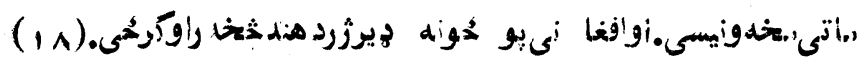

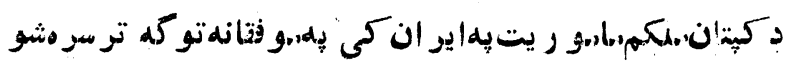
او در شوت بِذذر يعلئى و كرأىشول جهىاير انيو ه ترو ن نه راضى

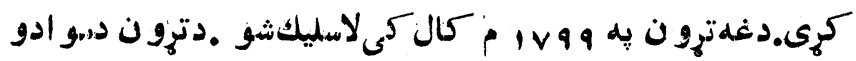
بر اسأسفر انسو يانو تهاجاز دنهو ركول كيدنجى اير انت لهداخلشي.

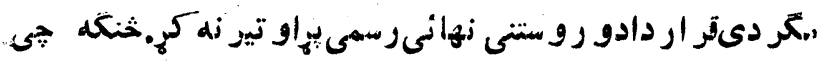

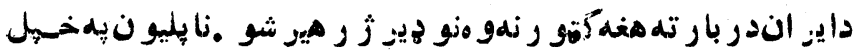

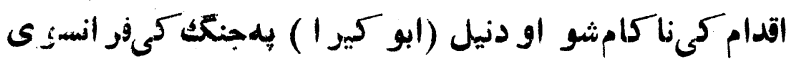

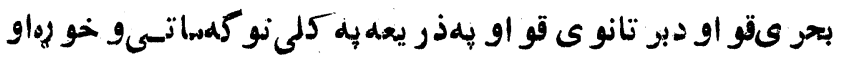

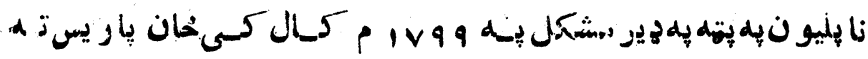

$$
\text { ( }
$$

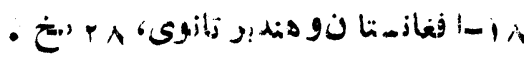
9 - 19

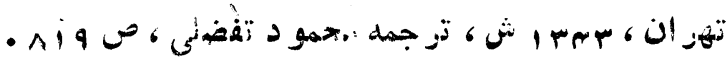




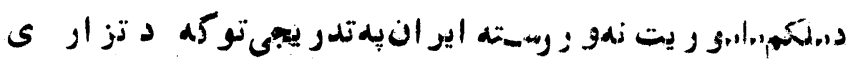

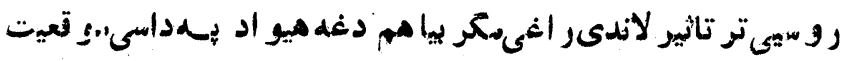

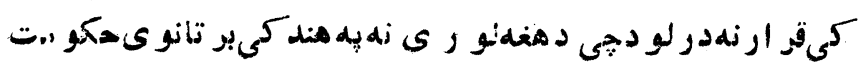

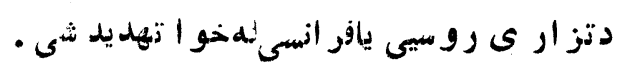

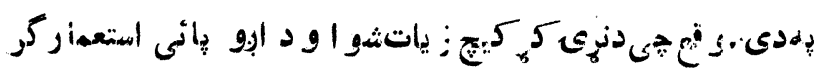

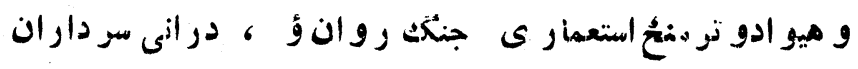

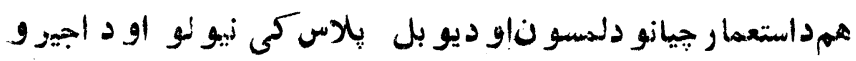

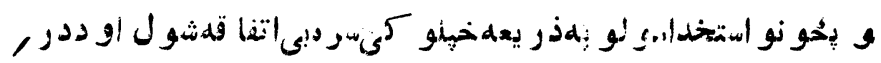

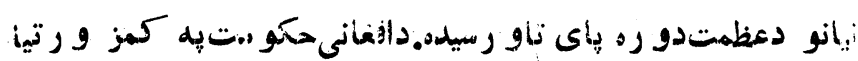

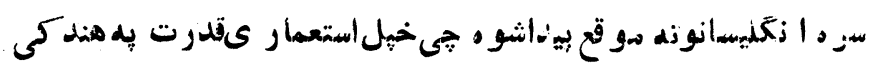

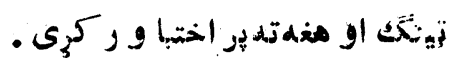

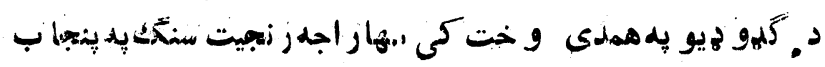

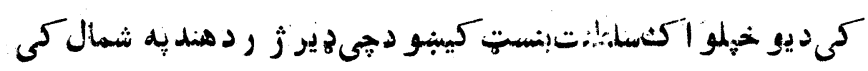

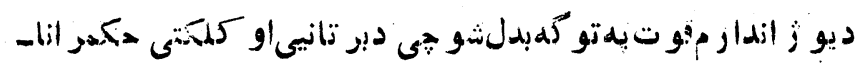

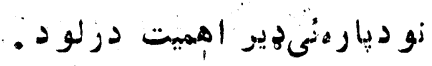

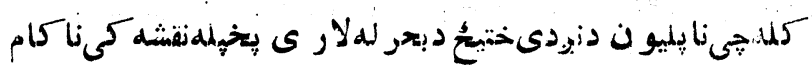

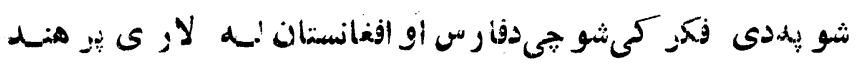

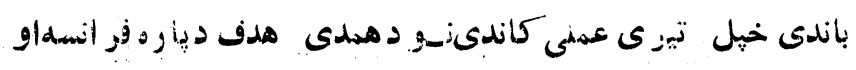

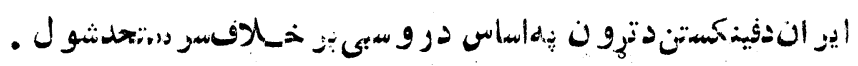

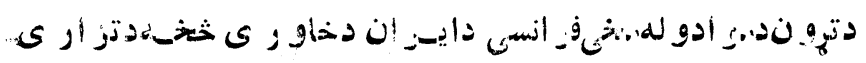

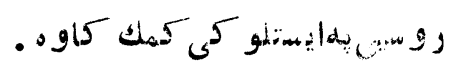




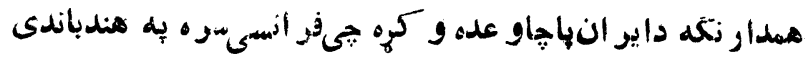

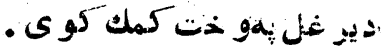

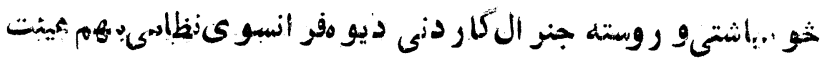

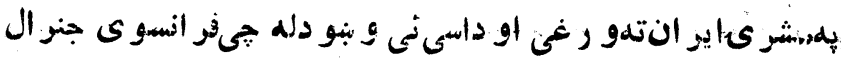

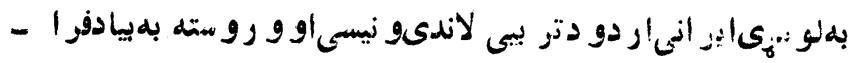

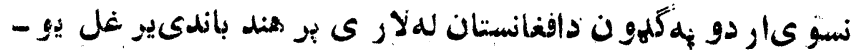

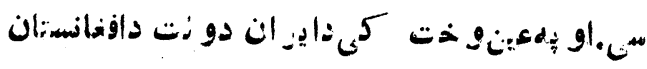

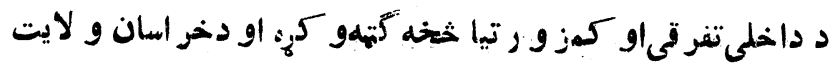

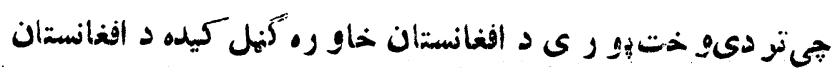

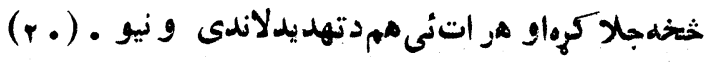

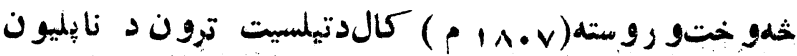

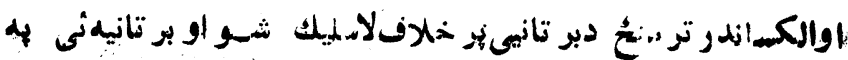

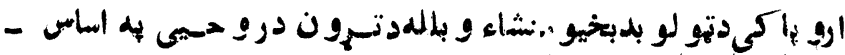

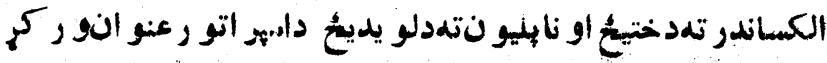

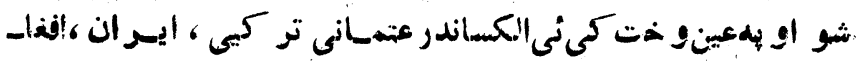

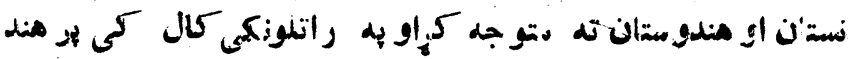

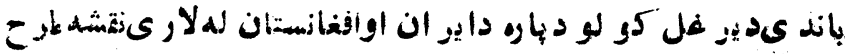

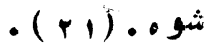

•

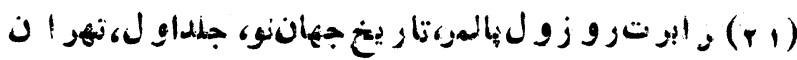
• 


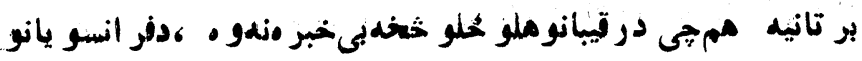

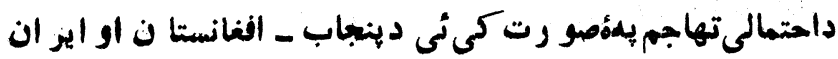

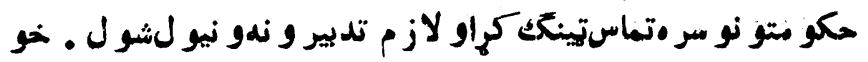

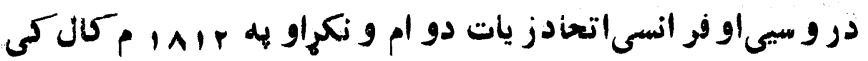

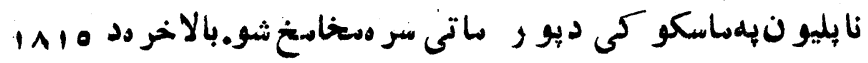
ميلادى كال دو اتر لويهو رو ستىماتىخولولوسر ه منده تهدر ميدو

$$
\text { خو ب او خيال ئى للمسو • و لاه. (r ) }
$$

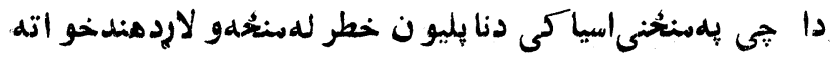

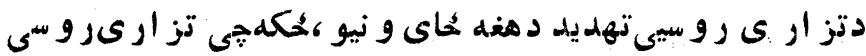
ديتر كبير دو ختنهد هند د سبهندر تو دو او بو ته درسيدو هيله در

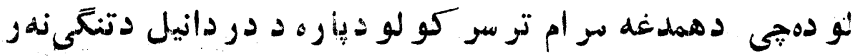

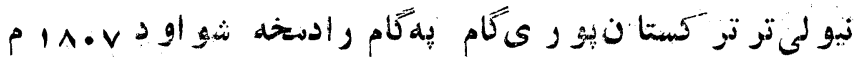

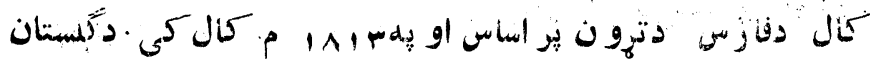

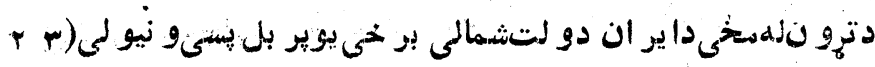
يه و نيو هي با يدد مندو ستانخو اتهدتز ار ى رو سيى دير متتحك ديخه و نيو لشى.لهنلىخو اتز ار ى ر و سيى مندتهدر سيد و او دهغه

(r ) Louis Dupree, P. 369. W.K. Fraser Tytler, Afg hanistan, London, 1967, P. 80 


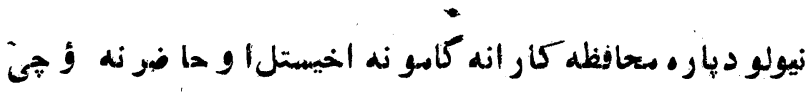

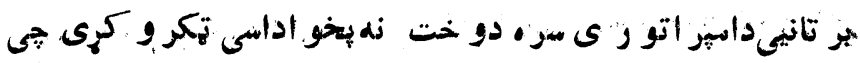
دجكَّى سببشنى.تز ار ى رو س بيا هم دايو انير خلاف جمَو ته

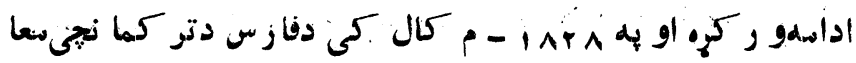

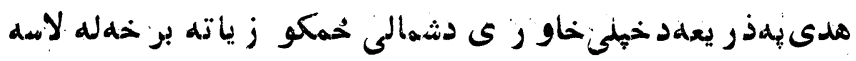

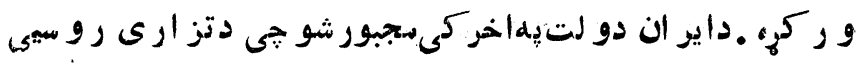
سر همو لهو كرى او ددى و و وسته بيا دتز ار عى رو مبيى د لاسله

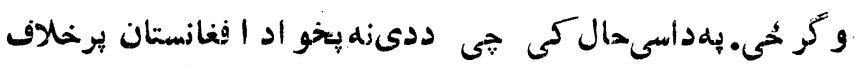

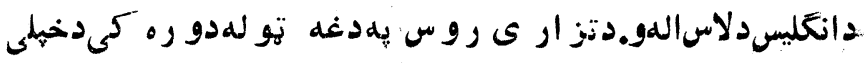

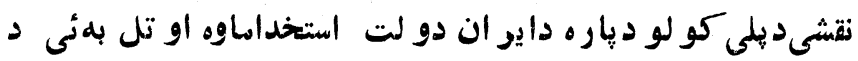
اير اندولت دهر اتد نيولو ديارهجسى هئدكسلى شمير ل كيده

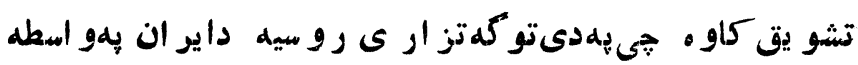
هنداو د هندسمندر تو دو او بو تهخيله لاره نبو دى كئى (rr) دتار يخ بهدىحساسو خت كى جى اسهير ياليستى هيو اد و دمند

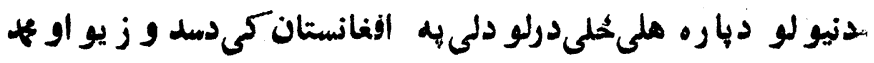
زيوترمنيُ دتاجاوتتختاوقدرت ترلاسه كولود بار ه سختجنسجكاوجدال رو ان ؤهى كو رني سبار زو به نتيجل كسىس كسزى قدرت

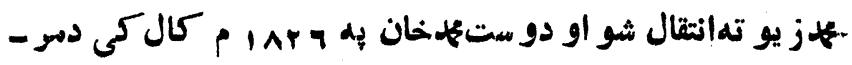
كز ى جار وخهله اكك قدرت بهلاس كى و اخيسست او د افغا نستا ن

.

4 $-4 r$ 


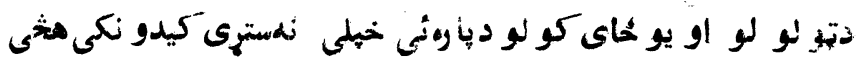
بيل كوى .

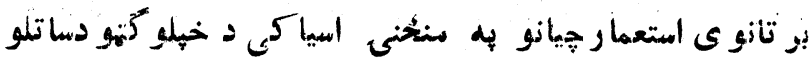

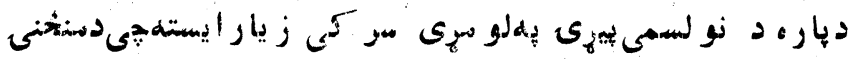

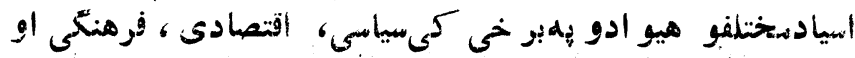

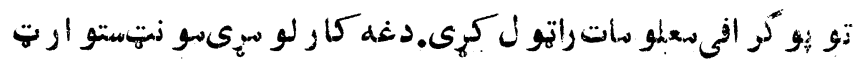

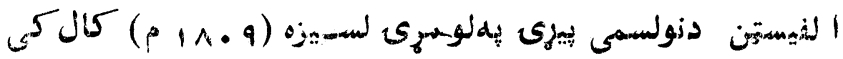

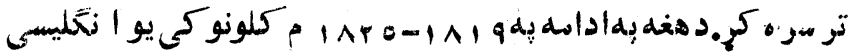
هيئتدمو ركر فتاو تر بيك بيهمشرى افغانستان تهراغى او دافغا-

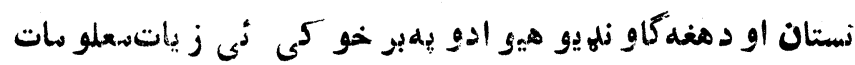
خهلو استخبار اتى لدار و ته و سبارل .الكساندر بر نس دبر تانوى

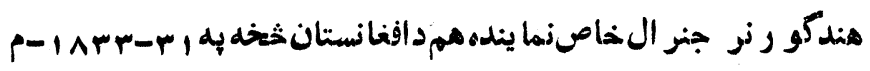

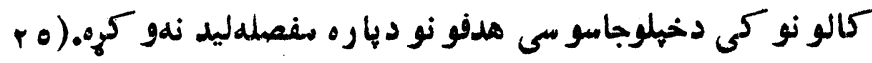
بار كز

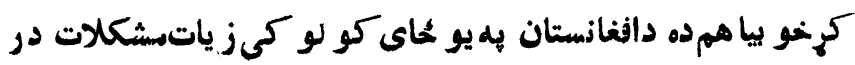
لو دلسدو ز ى كاسر انبههر اتكى-بار كزئ كند هار ى ور

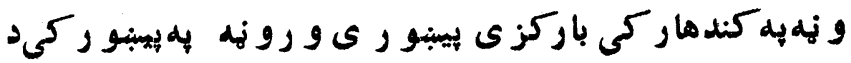

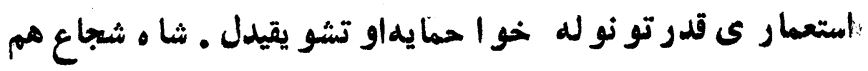

Afghanistan past and Present, $p 100$.

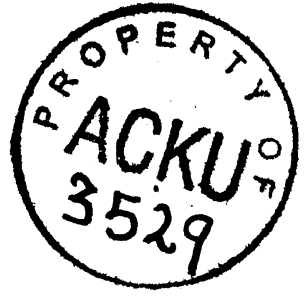


د مباداو رمحى ديار مبلدلو ديانه كى دبر تانيهاستعمار رى قدر تلد

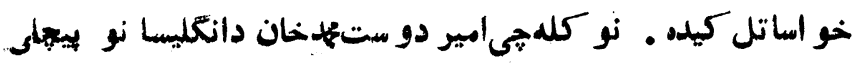

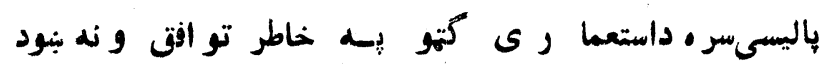

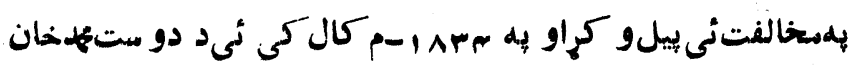

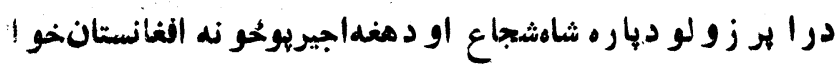

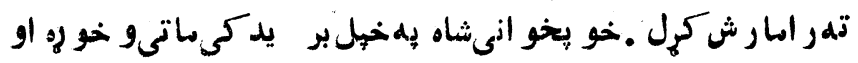

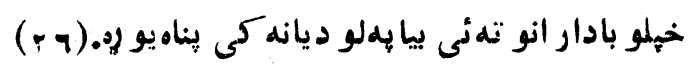

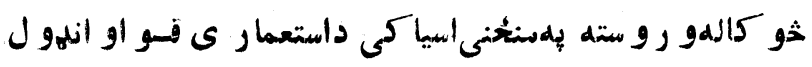

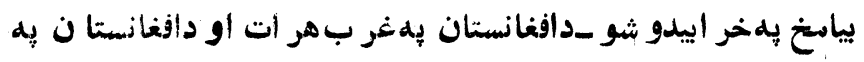

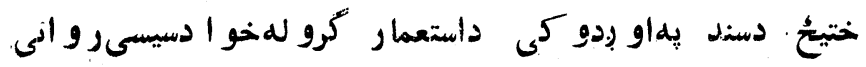

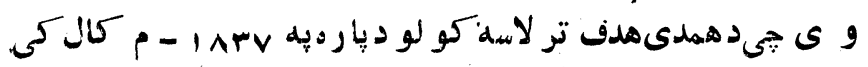

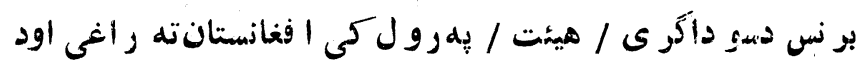

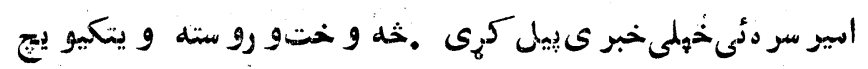

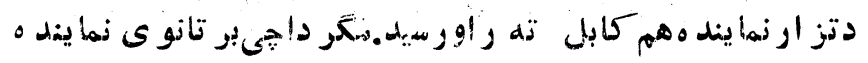

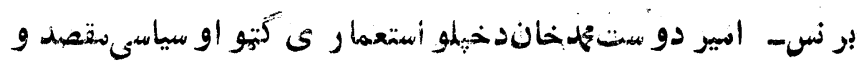

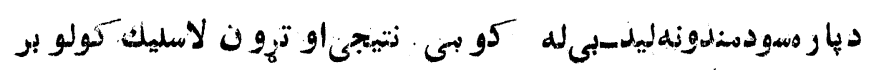

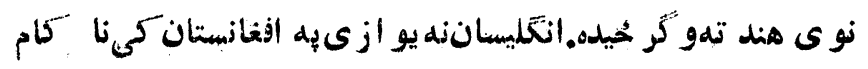

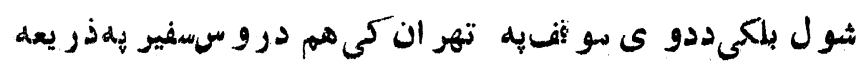

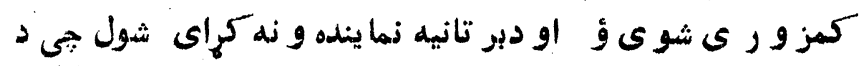

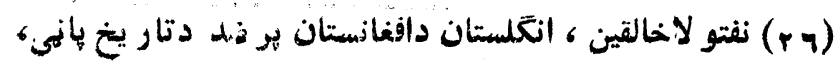

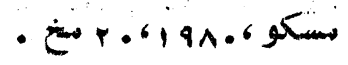




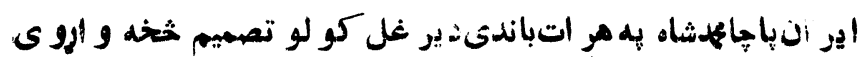

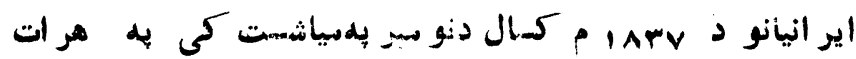

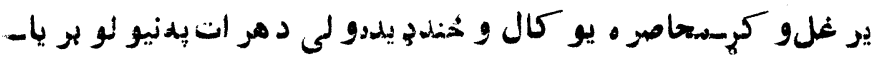

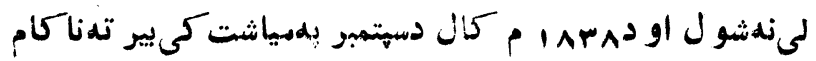

$$
\text { اير انتهو كر خيدل . (rv) }
$$

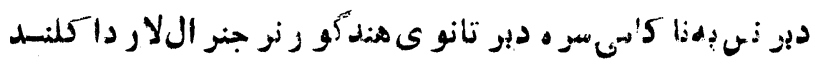
او دده سشاو ر ين دىنتيجى ته و رسيدلي جي دادير دو ستهمخان

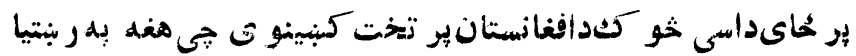

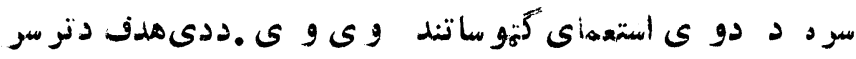

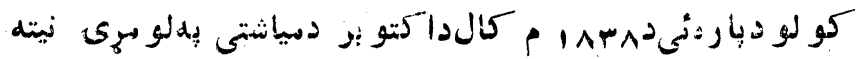

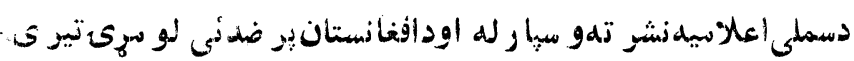

$$
(r \wedge) \cdot r^{5}
$$

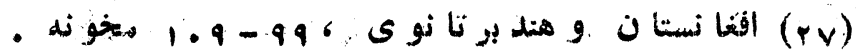

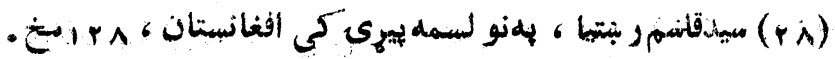




\section{دويمفصل:}

الف:د افغاناونكليس د لوسئى جكاهى بهوخت كى دافغا نستانسيا سىوضعه:

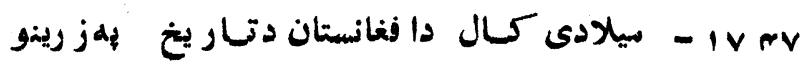

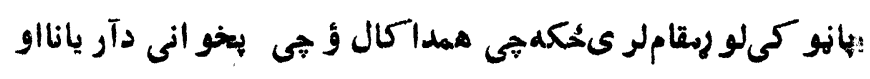

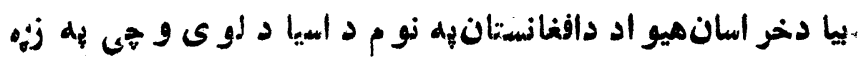

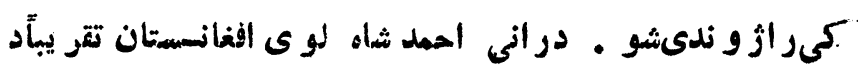

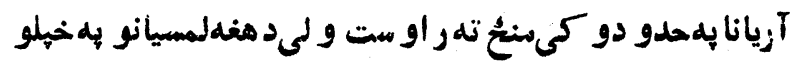

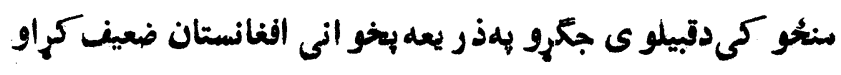

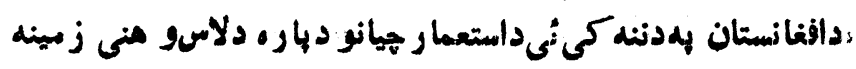




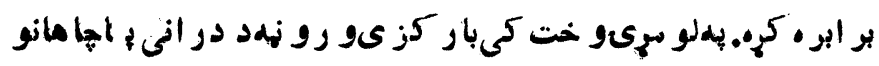

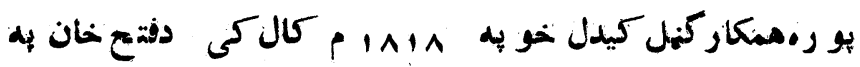

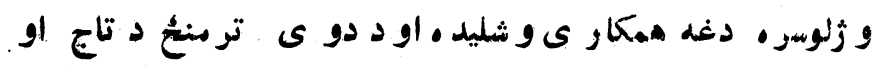

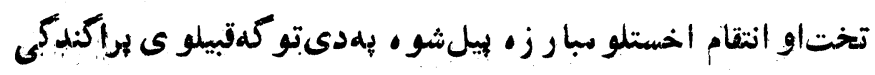

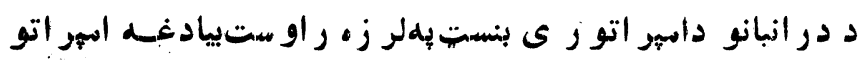

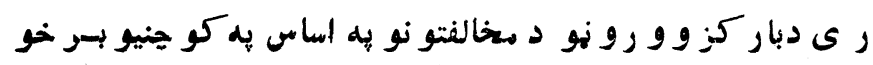

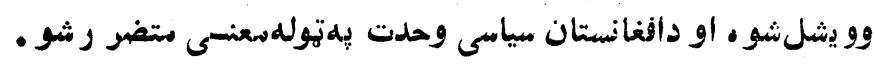

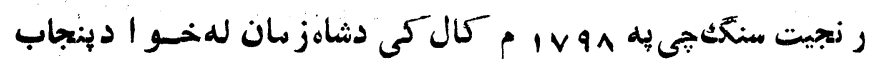

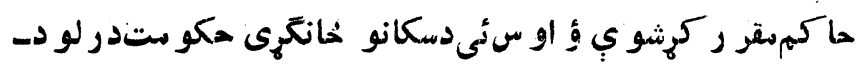

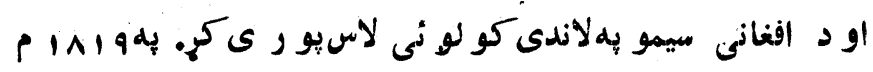

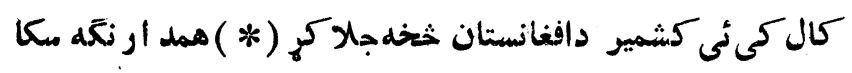

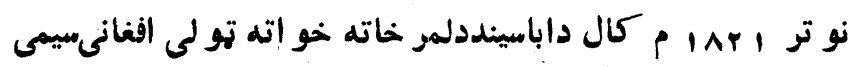

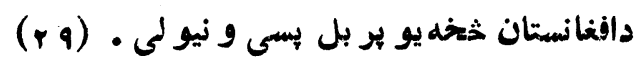

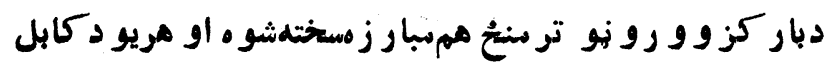

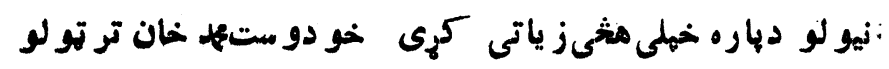

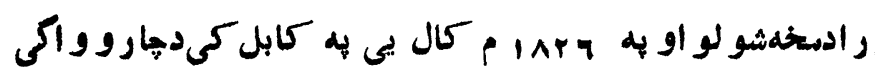

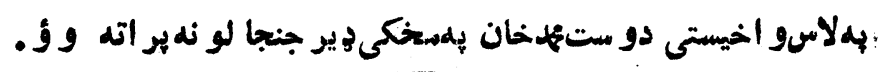

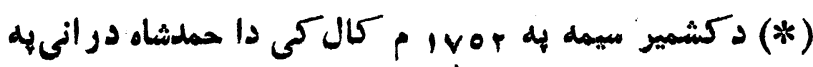

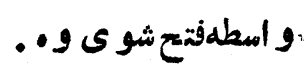

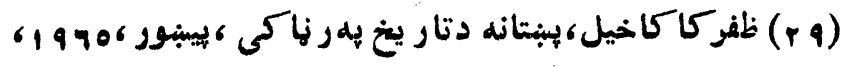

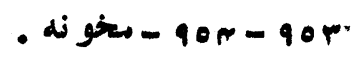


مدوو ز ى كامر ان به هر ات كى حكو متتدر لو د كند هاز دبار كز و كندهار ى و رونو كندلخان ـ شـير دل خـان - رمهدل

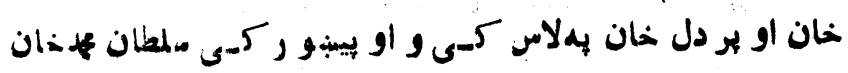

$$
\text { هكو مت كاو •. (r.) (r) }
$$

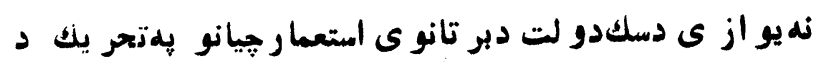

الفغانستانخخه دسيمو بهشكو لو بيل كرى و ؤ بنكى اير انيانو مم د د تز ار بهتشو يقد هر ات دجلاكو لو هخى د درلو دى لكه ئى بيه

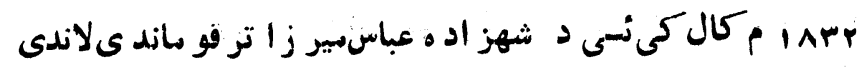

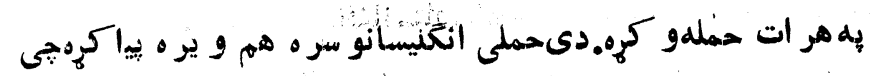

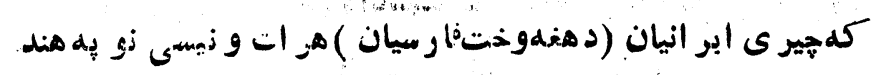

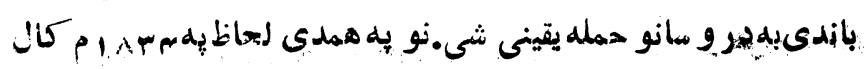

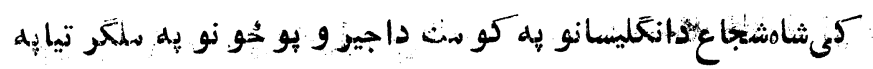

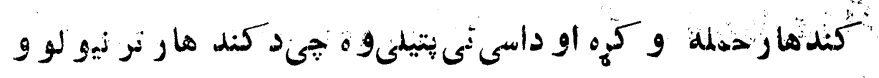
روستهد كابل به لوريو ديخ و لاريشى.و لى دو ستهمخان كنده هارى

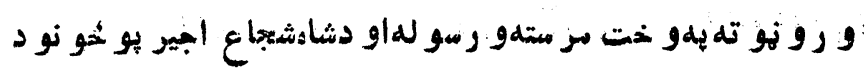

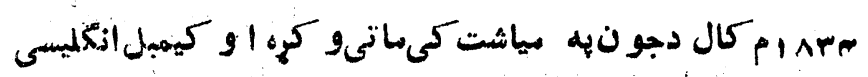

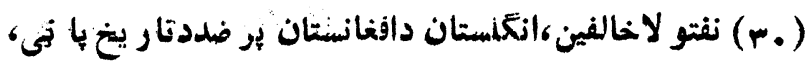




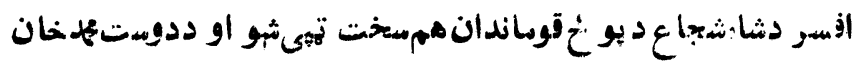

$$
\text { له لهو ا: نيول شو • (r) }
$$

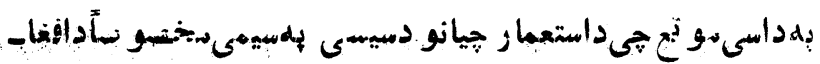

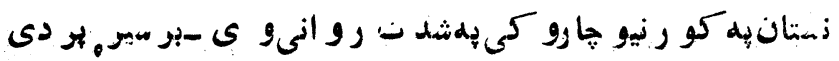

جىشانشجائ او خنار هـ. دو لـن بو كند هار او هو ات حملى و كرى

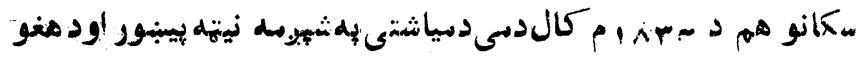

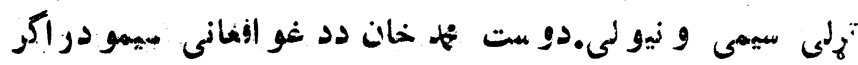

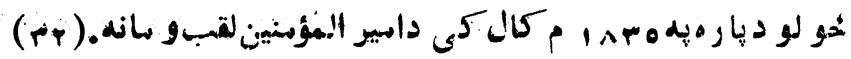

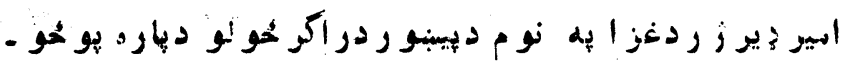

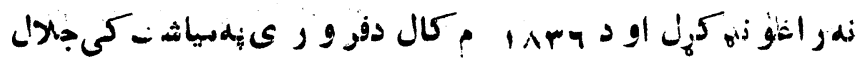

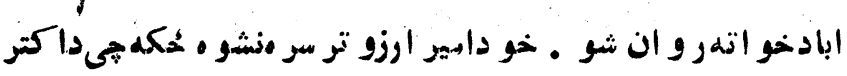

أنها

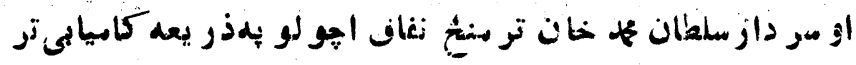

$$
\text { لاس }
$$

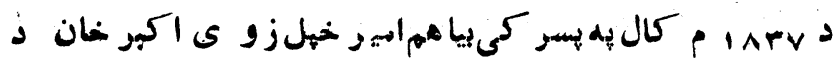

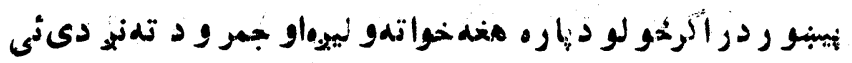

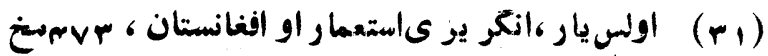

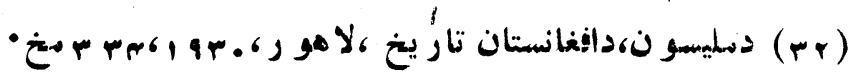

(بr) 
مكانو تمستختهاتىوركيه او دسكانو ستر جنر ال هر سنكَك و و زل ل.

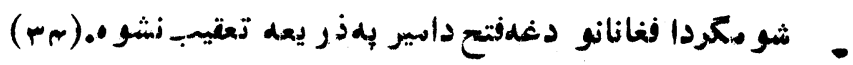

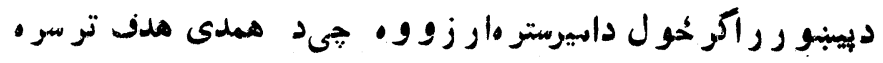

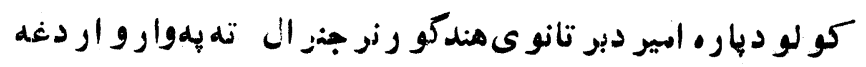

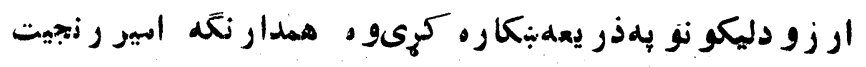

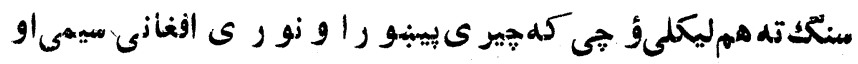

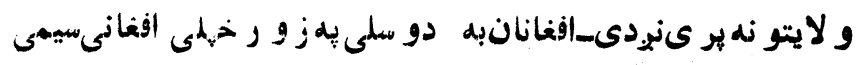
اير ته و نيسى • (ro)

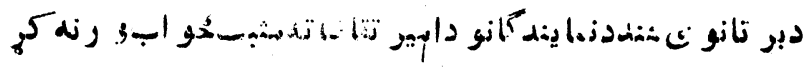

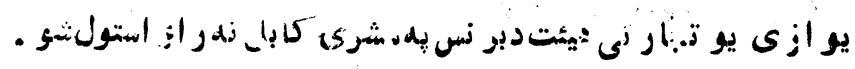
ازكنيسانو له يو ىخو ا دسكانو سر ؛ د دوستى ترو فندر لو داوسكانو

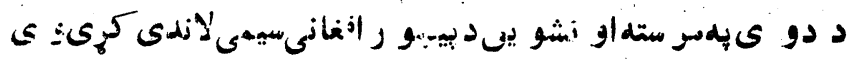

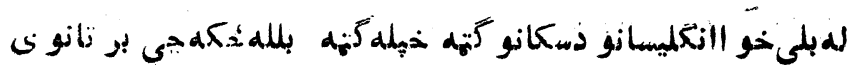

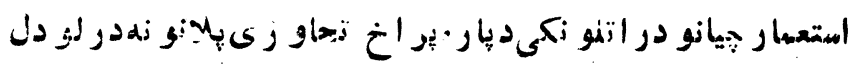

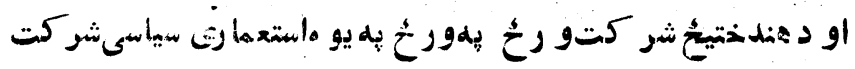

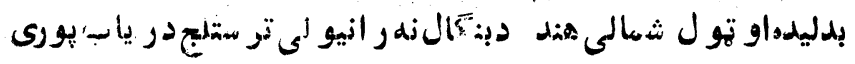
(كار)

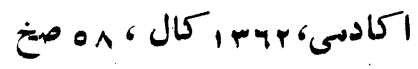

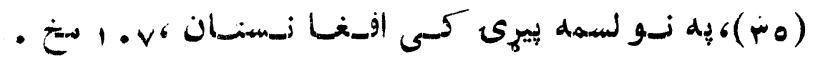
- r. - 


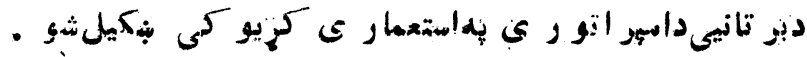

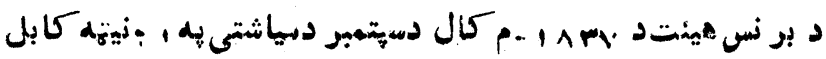

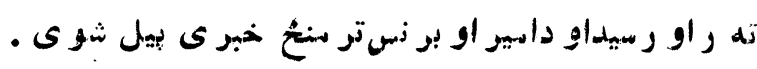

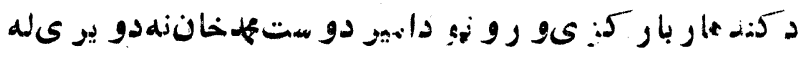

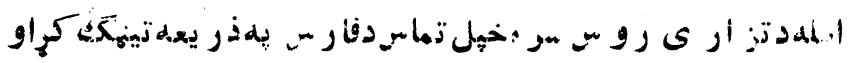

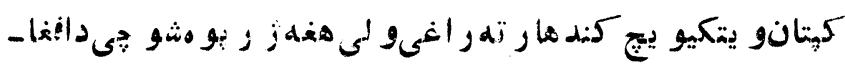

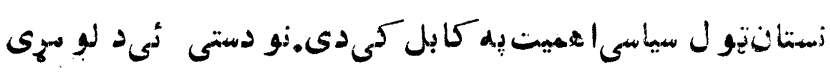

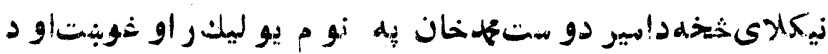

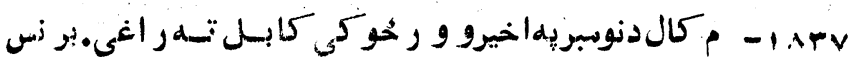

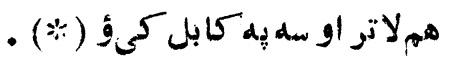

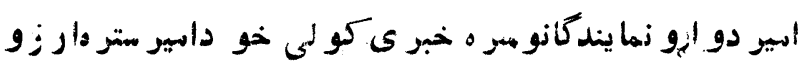

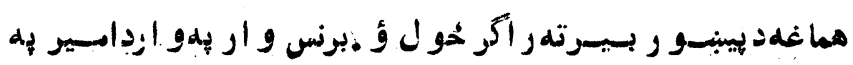

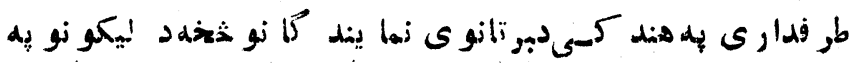
ذريعهداميودىتناضاتهدسثبت خو ابوو ركو لو هيله كرىو ث.دكر

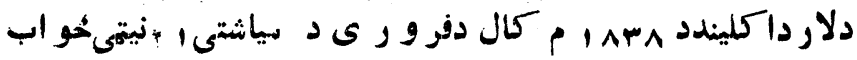
د دو ستمخهانتيو لو سطالبا تو او تضتقاضاو ته ر دخو اب و و ايه. (ri)

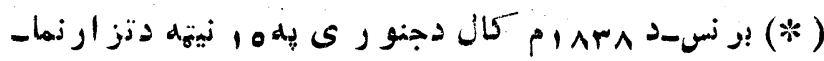

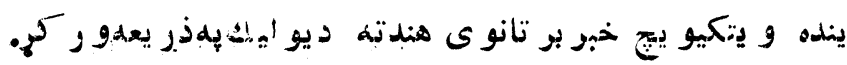

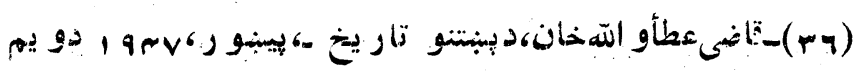
- جلد ، 


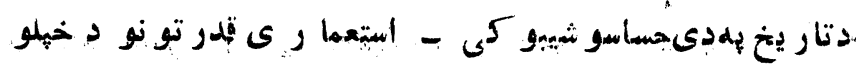
خمككو دير اخولواو دنو رو استعما رو لو دياره بِه جنتكتياسزه دد و رو ستهذباتىاو كو حنيو هيو ادو بهدننه كى لاسو هـنه كوله او

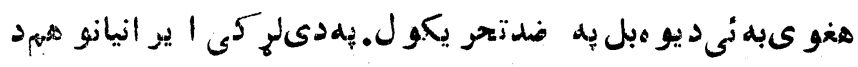

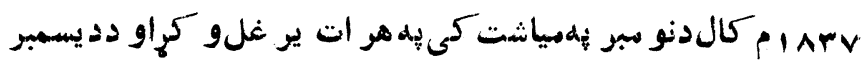

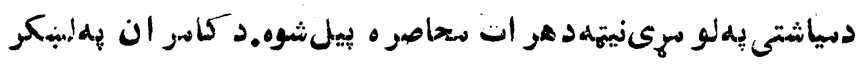

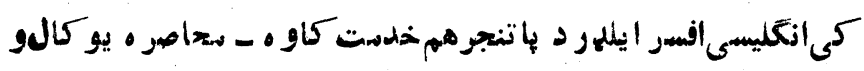

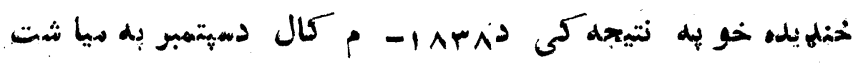

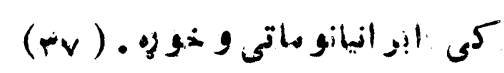

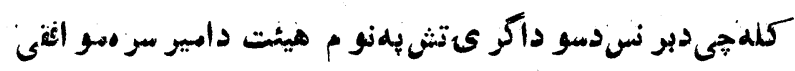

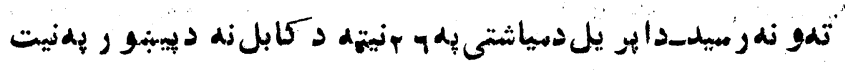
رو ان شو او دلار ى خُخهنى يه سمله كى دبر تانوى هندكو رنب

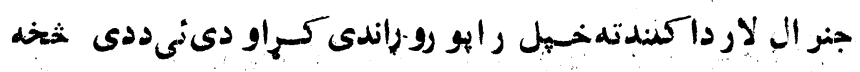

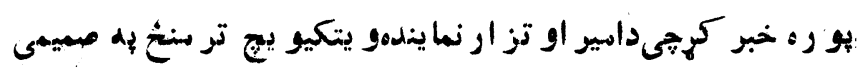

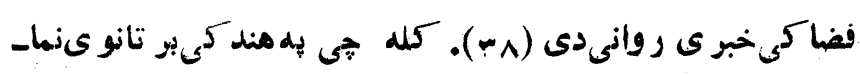

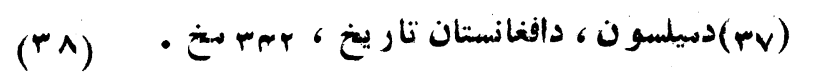
Arthur Swinson, North West Frontier, London 1967, P 38.

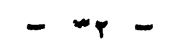




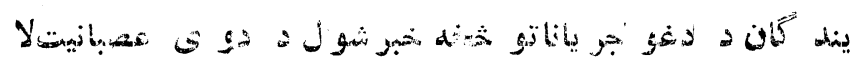

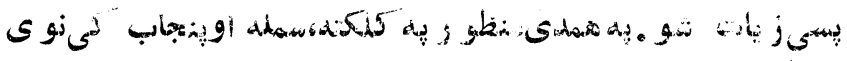

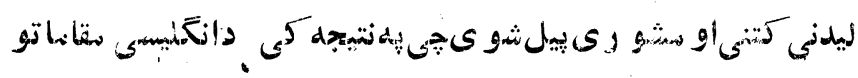
نتيجهَ'

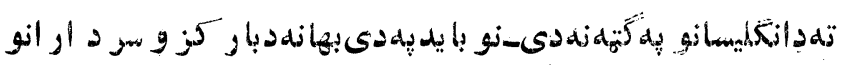
سر هخبل عنلخ إقو شكول لشى أو دبر تانوى هيندد بو لو أؤسر حلد و نو

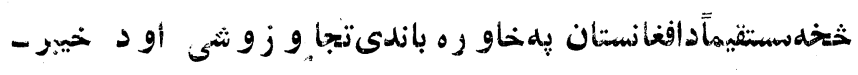

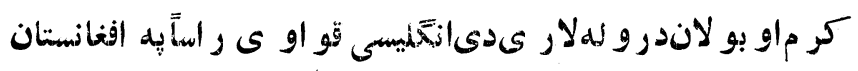
باندى يه تيو.ى لاسبو ر ى كرى أو دبار كز و سو دار أنو زما مد

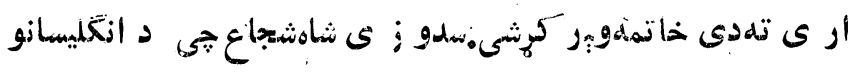

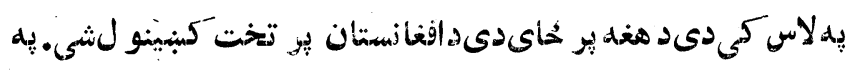

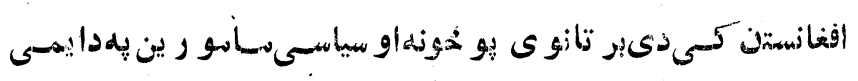

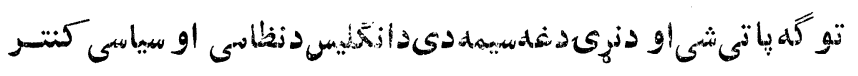

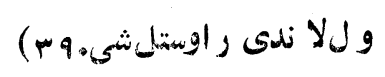

. digis 


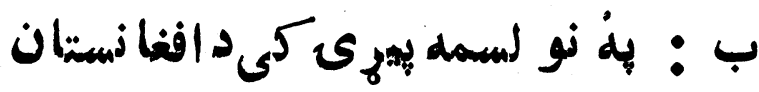

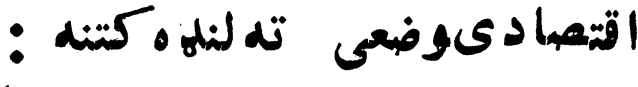

يلهنو لسمهبيرى كسى افغانستان يوه فيو هالى،نيمهفيو هالى او ماقبل

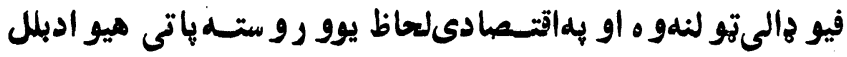
كيده.د.مفيصدو ثخه ز ياتنفو سيه كر منهاو مالدار ىمشغول

$$
\text { وؤ (. (r). }
$$

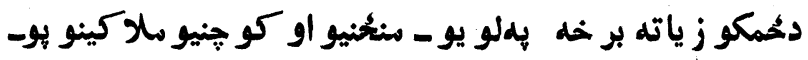

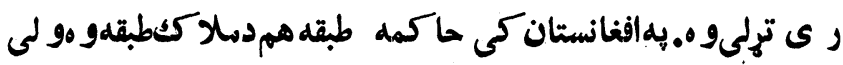

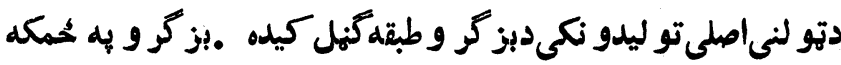

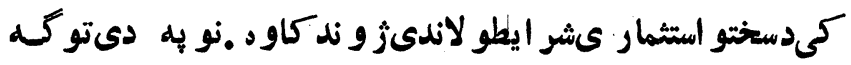

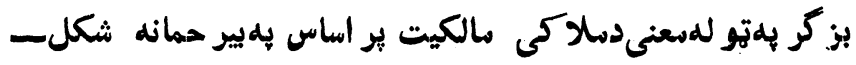

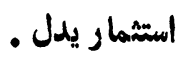

(. م) ام-كى بهكو لين، تصو يو اقتصادى وسياسى افغانستان، تاشكندة

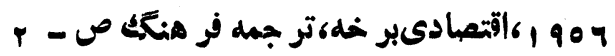
- re - 


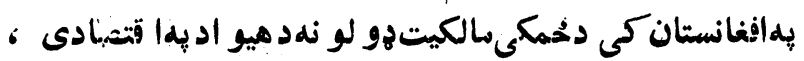

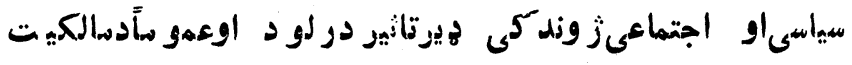

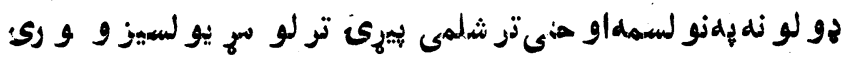

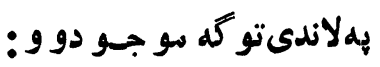

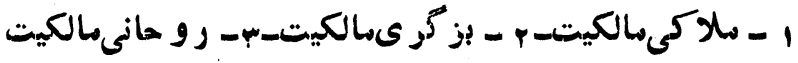

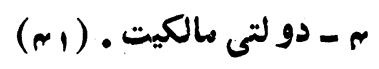

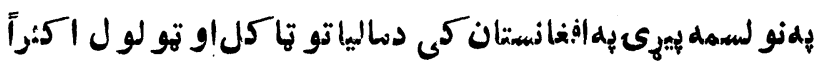

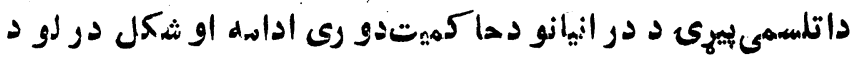

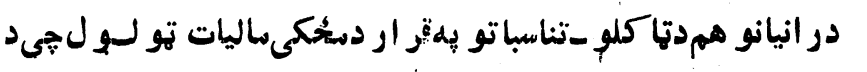

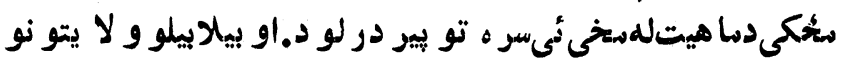

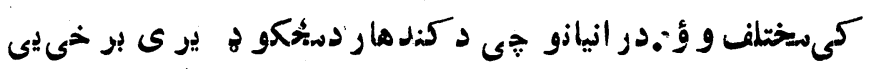
دولتته دعسكرى خدست يه.قابل كى بيهخيل لاس كى نيو لى و.ى مالياتنهو ركول لغغلز يو يو از ى يلهلبوه أنهازه ما ليات و ركول تاجكانو تر هغd ز زيات ماليات تاديه كول ، دكشمير و لايت

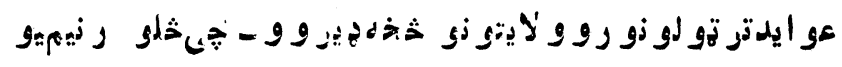

$$
\text { رو بيو تهر بسيدل ـ (rم) }
$$

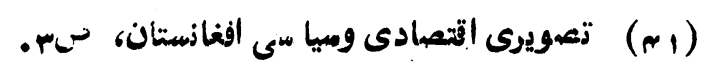

• 


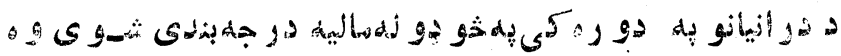

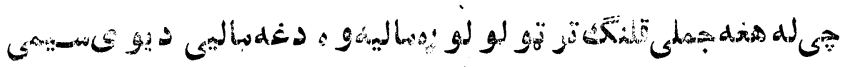

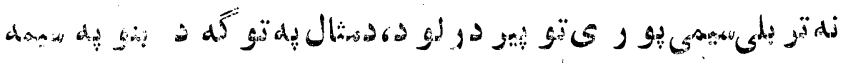

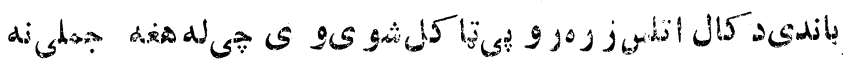

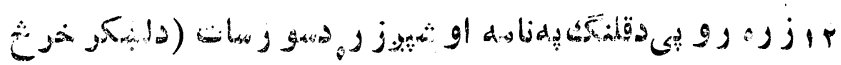

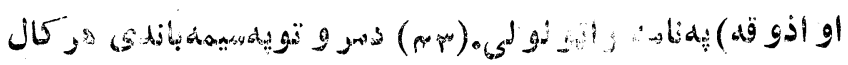

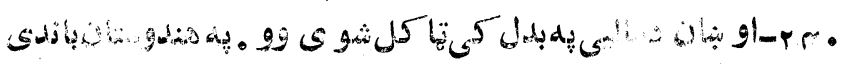

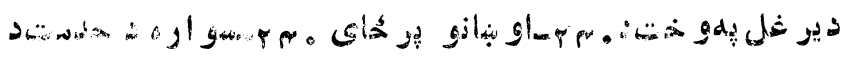

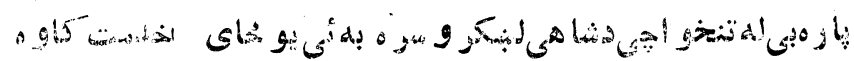

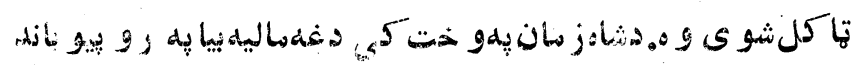

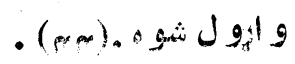

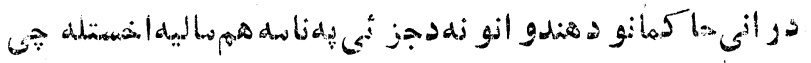

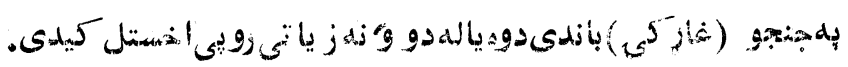

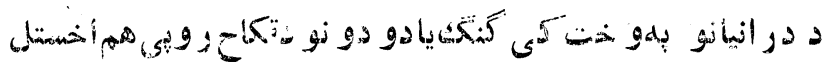
ثوى

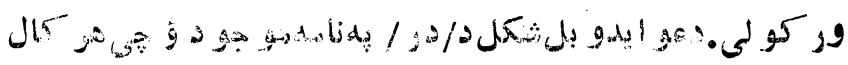

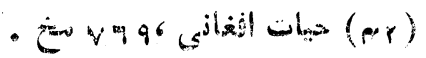

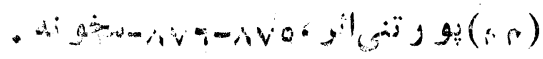

$$
\begin{aligned}
& \text { - } \\
& \text { - rq - }
\end{aligned}
$$




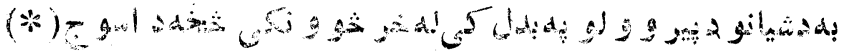

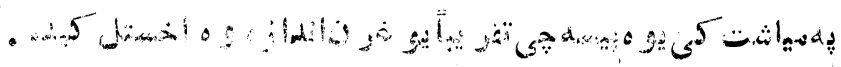

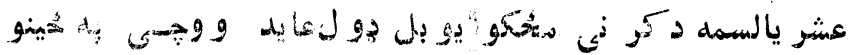

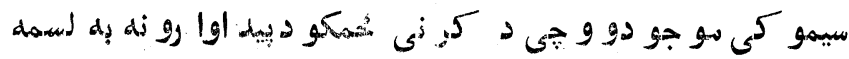

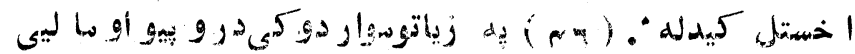

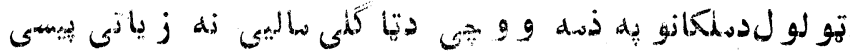

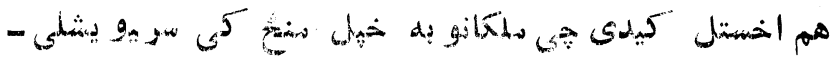

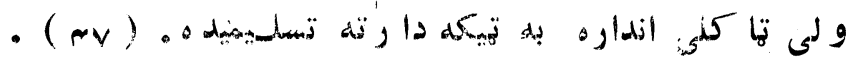

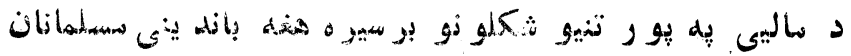

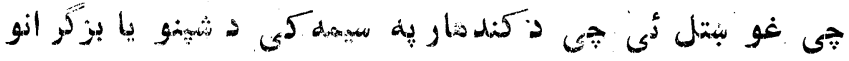
به تو

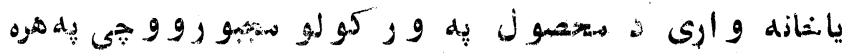

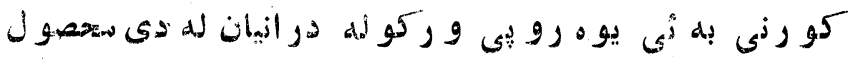

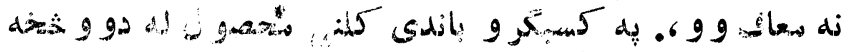

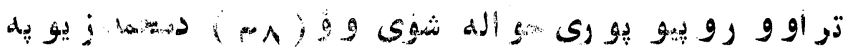

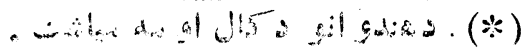

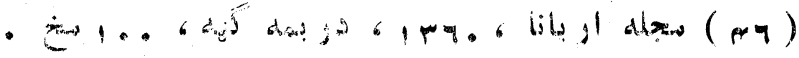

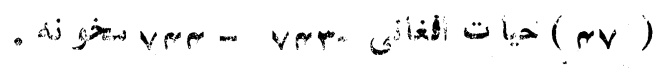

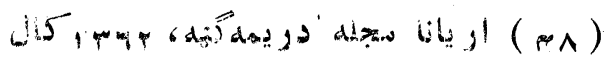


دو روكى د افغانستا ن شتمن ولايتو نه دداخلى متخا لفتونو

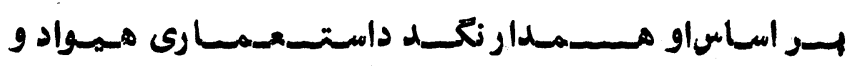

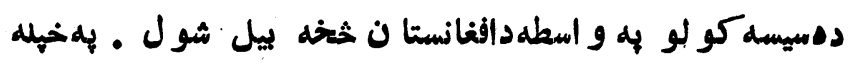
ازغانستان هم به مياسى لحاظ به ورو وا حد و ونو وو يشل

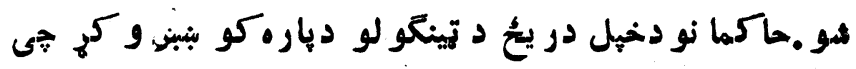

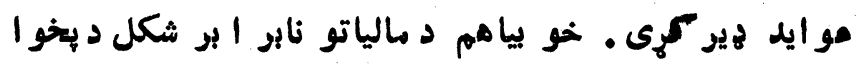

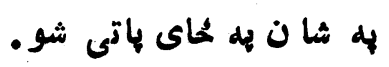

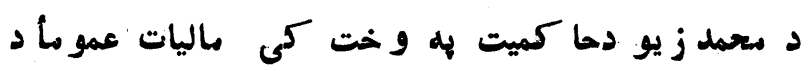
او بوله كر اره جى كمكى نوىخهو بيدلى يادهغو ئايو نود اوسيد

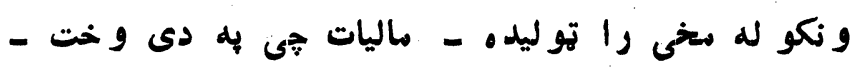

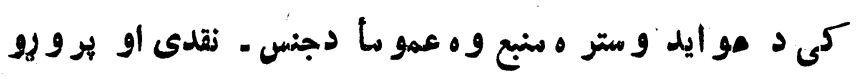

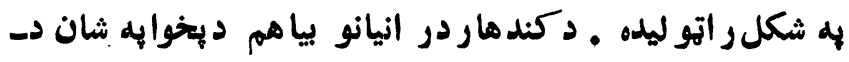

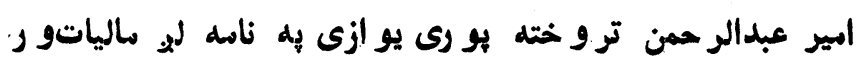

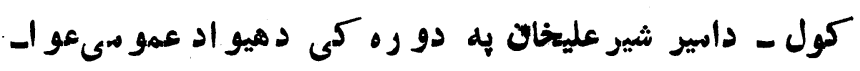
يد زيات شول او به مالياتى سيستم كى اصلا حات منئ ته راغلل او به كممكه باندى ما ليات هـ يو شول جیى دغه مالياتد

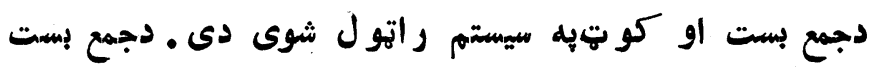
لا جمع بندى د مالياتو هغلتاكلى دقدارؤ جى بله يوى سيمى

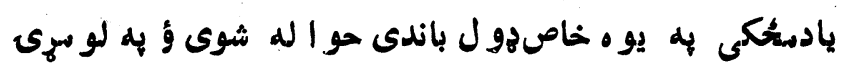
وخت كسى به جنس توليسد ل ـ خــو به ليسر و او نار امسـو - rᄉ - 
ميمو كى به هيرو حالاتو كىد هغو دتحصيل مشكلات ددى-

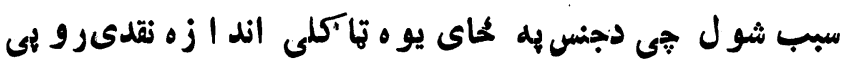
و اخلى دغه رو بيو اندار هله يوى سميى نه تر بلى سيمى بو رى

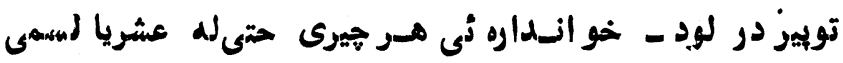

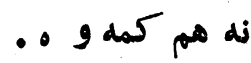

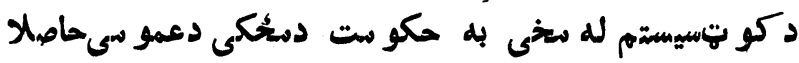

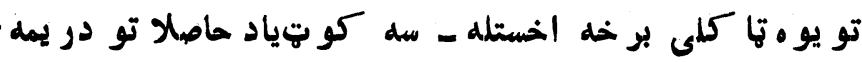

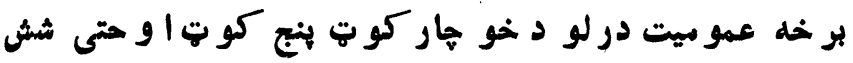

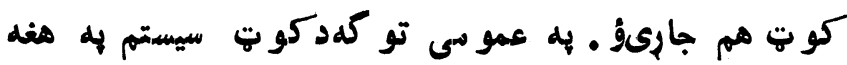

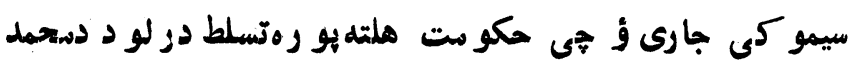
ز يو به دو ره كى هم ددر انيانو دوخت ملاكى ما لكيت لهيت

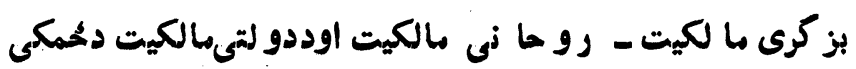
دما لكيت عمدهشكلو نهو و. ددو لتى ياسر كارى حمككو بر خهد افغانستانهيه تو و سيمو كى يو شان نهو د دجلال آباد به سيمه كى دد و لتى كمكوحاهي تو نهدوه دو يمه يا نيمانى اخستله ـ به غز نى كى لهى ددو لتى مهمكو

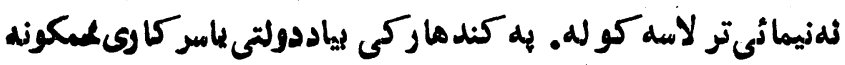

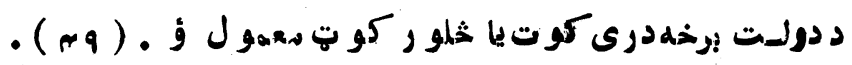

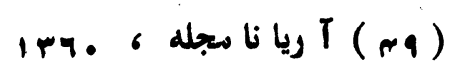

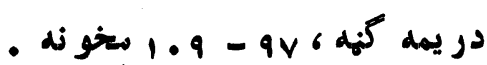

$$
\begin{aligned}
& \text { - rq - }
\end{aligned}
$$




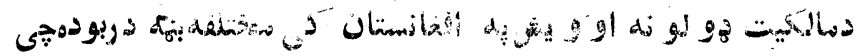

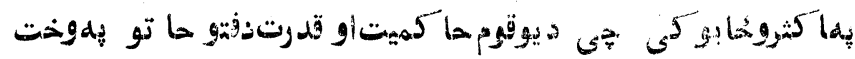

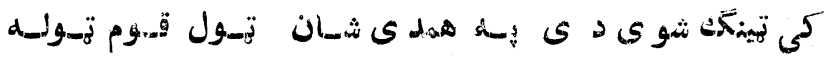

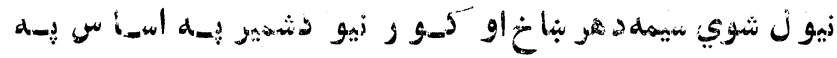

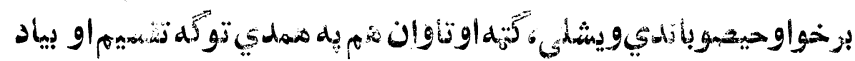

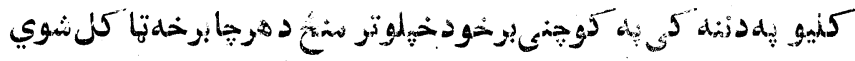

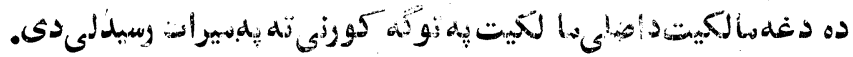

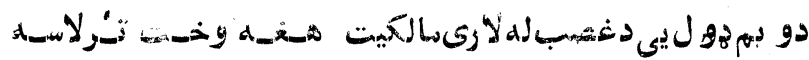

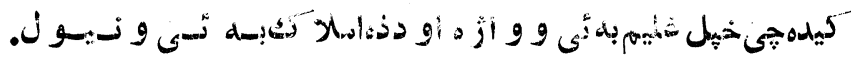

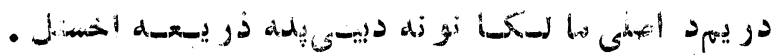

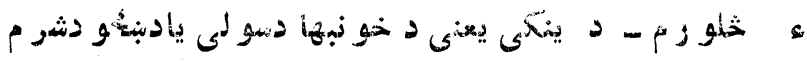
يلهبلد .

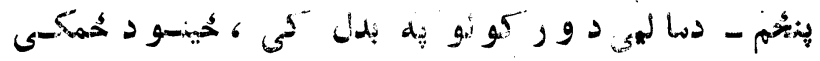

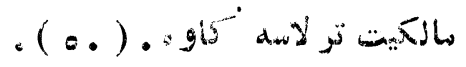

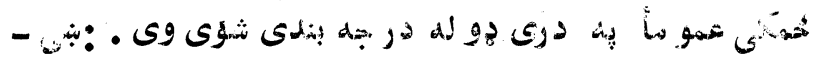

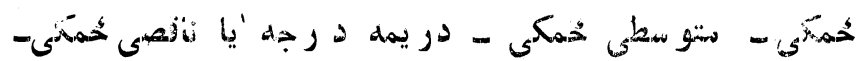

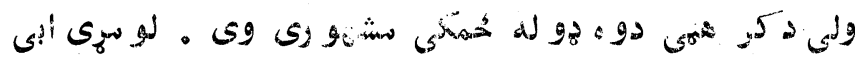

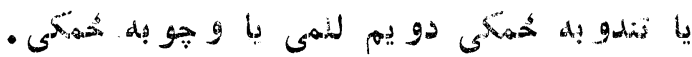

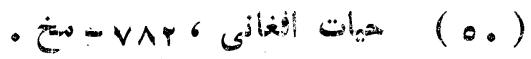




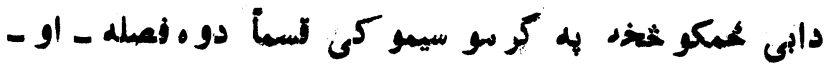

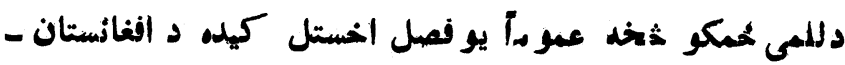

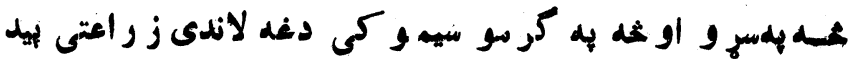
وار عمده عاملا ت وو: ل

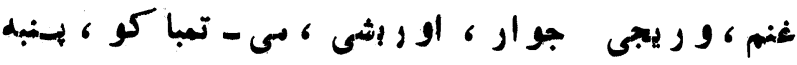

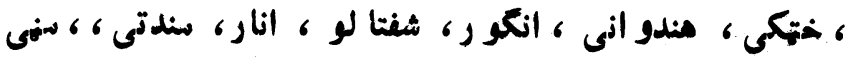

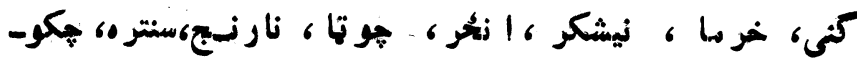
تره، كيله ، ليمو ، ام ، هار ميغز ، ناكك ، توت ، لبلو ، تيلى

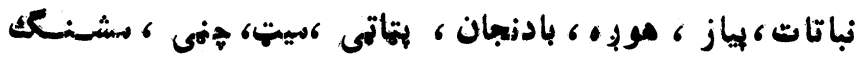
كو ر كمن، ،مترر ، بادر نك، كدو ،توي ،ز رد كى ، شو تله ، ر-

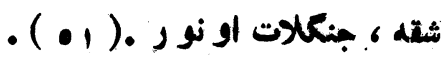

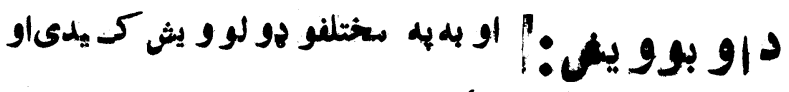

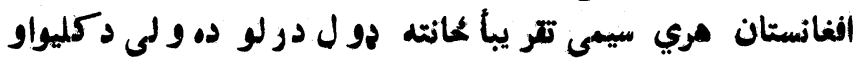

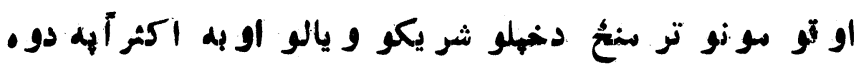
هوله و يشل كيدلى :

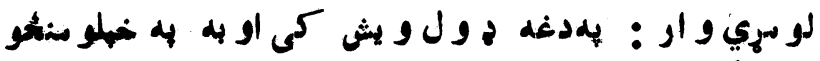

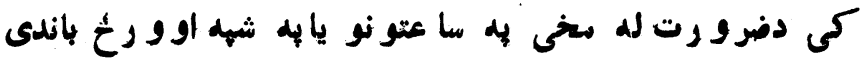

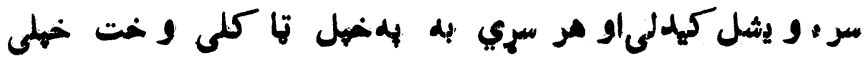

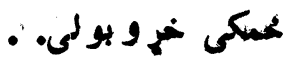

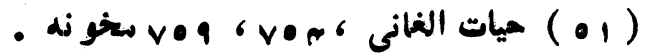


دو يم : به سشتر كمه و ياله كى يوإلركى تهه ده اولم كله

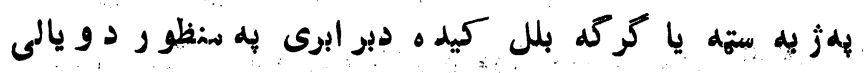

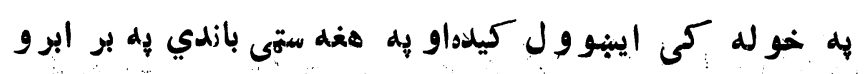

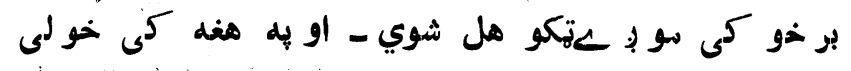

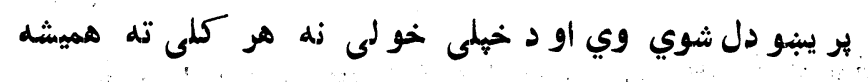

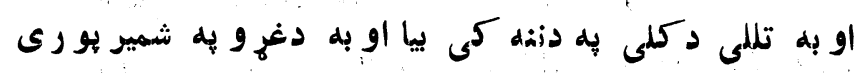

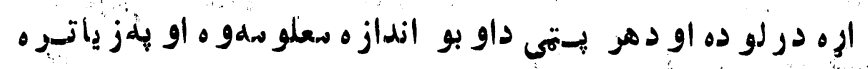

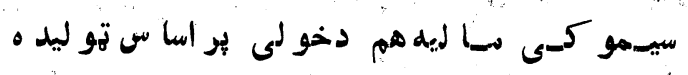

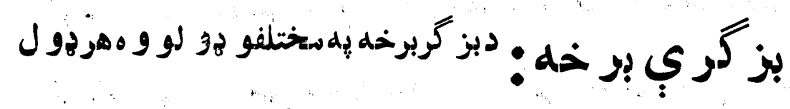

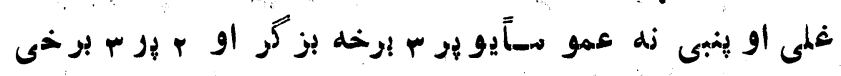

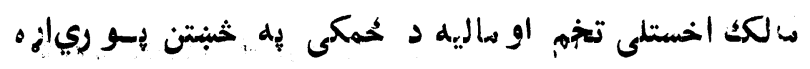

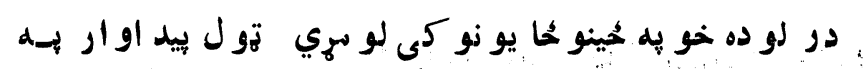

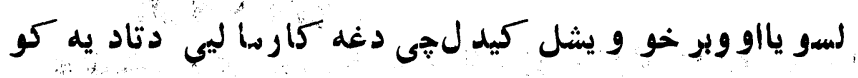
. لـو ديساره تيوسر هكيده .

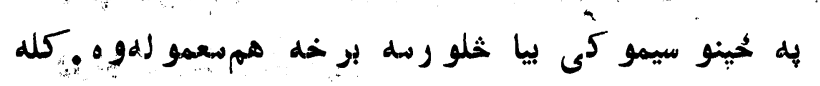

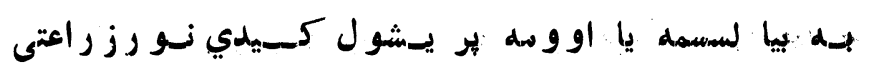

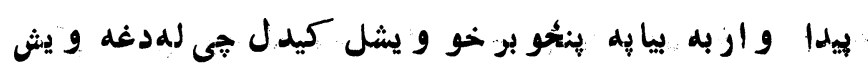

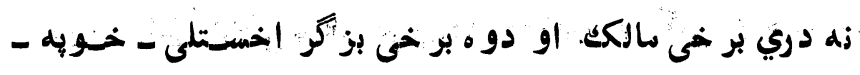

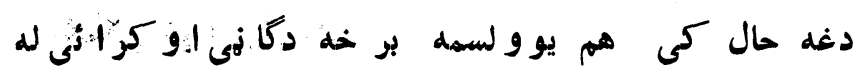

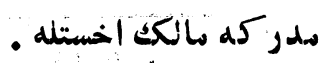




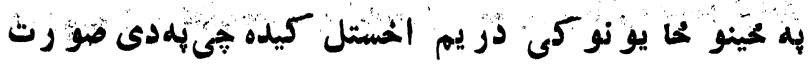

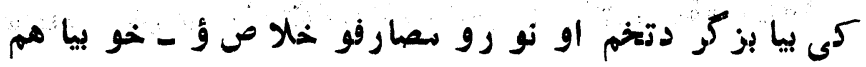

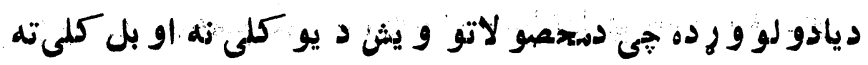

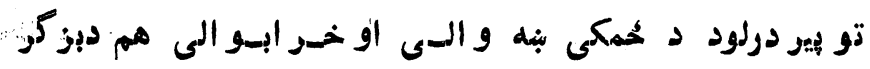

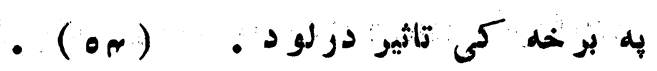

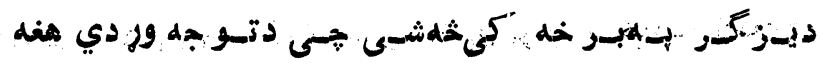

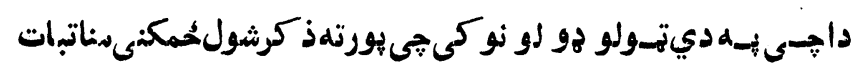

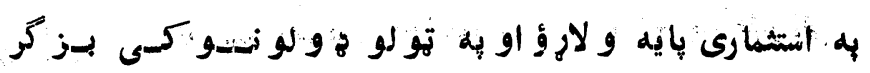

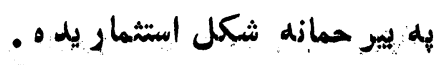

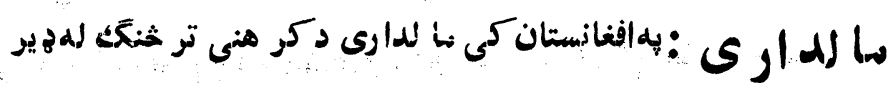
بخو ا خخه معبموله و ماو دافغانستان بلهتولو سيمو كى با لد -

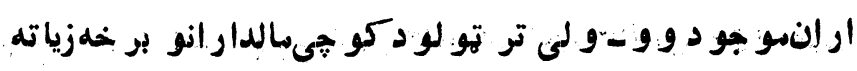

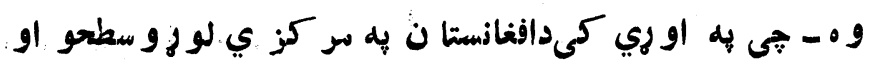

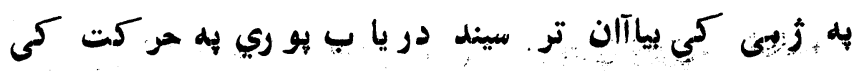

$$
\text { و و.). }
$$

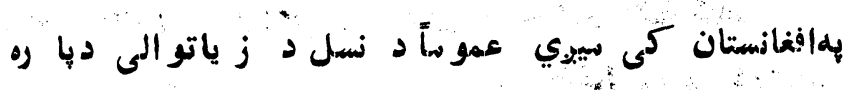

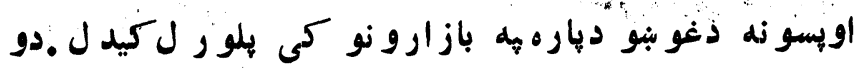

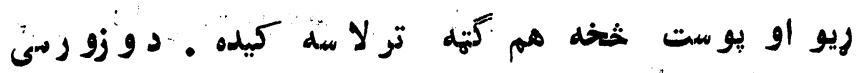

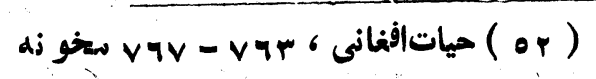

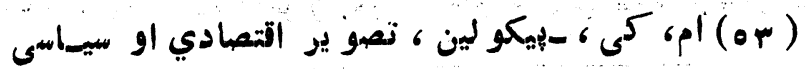

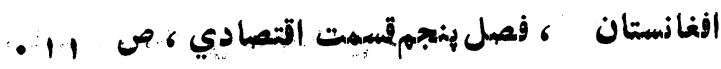

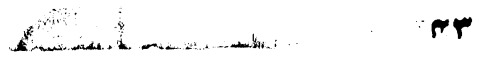




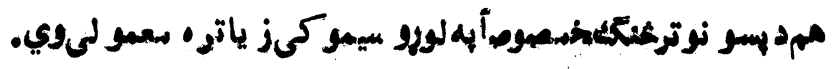

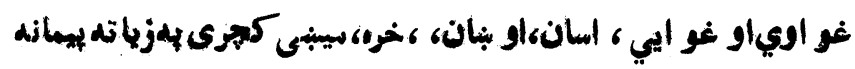

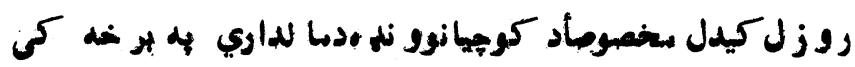

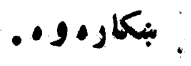

بهافغانستان كى دمالداري عمده نهصولات وري،يو ستكى،غورى

غو نبي، شدي، بنير ، كر ت او دمنوي نور مسمصسو لاتو و

$$
\text { ( ( or) }
$$

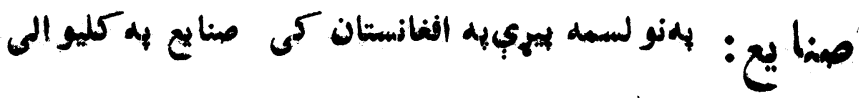
•خانكى هو لمعمول و وجى دطبيعى التعباد ضر و ريسامانثىتيارو. و باو دكليو يوز يات تعداداو سيدو نكى به خانكى فايعو بو خت

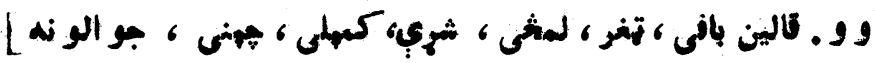

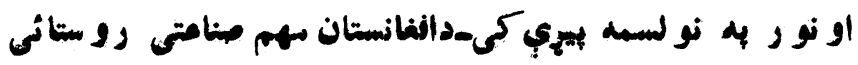
منايع بلل كبدل.

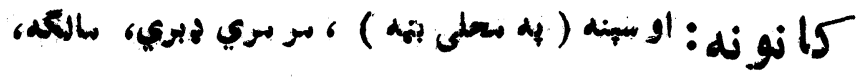
كر يهه احجار او نو رجى به محلى توكه توي كته كيده .

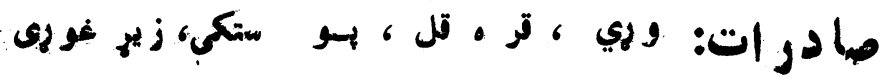

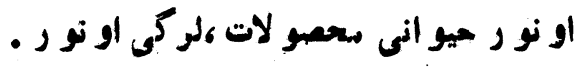

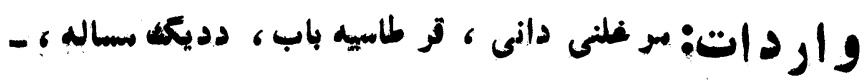
مالكد ، نيل ـ تيل، كو ركدن ، شكوه، بهنى باب اونو ر .

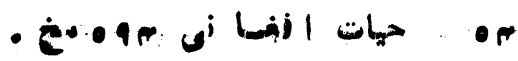
- re - 
دو ارداتو ز ياتو هبر خه سينسمين تو كر ان ، و ر يبنمين تو كر ان

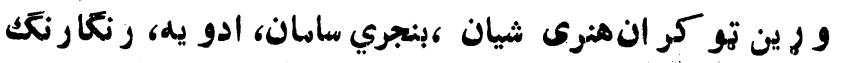

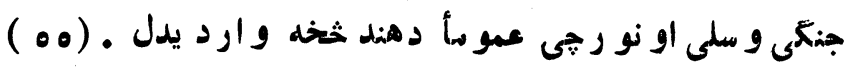

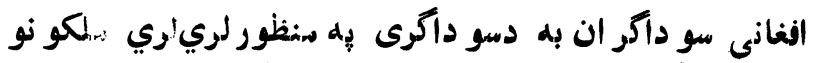

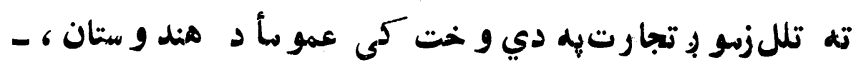
روس، اير ان ( د هغd وخت فارس ) تر كستان ، جين ، تبت ـ

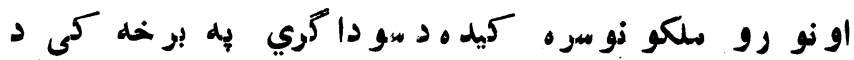

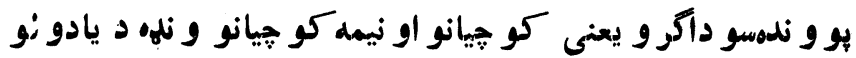

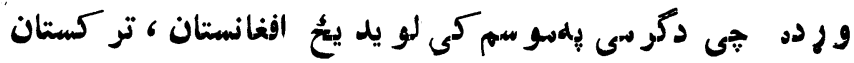

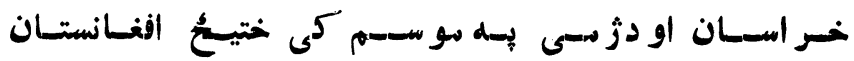

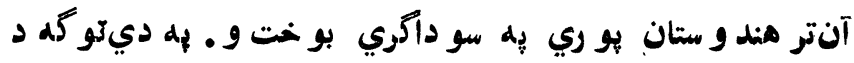

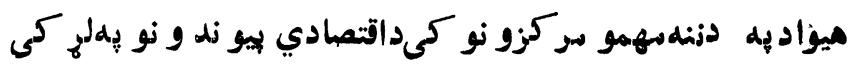

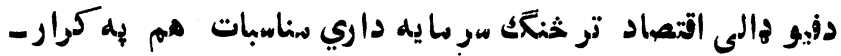

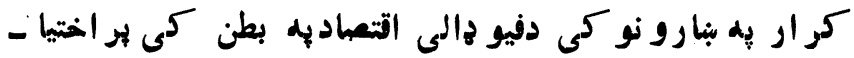

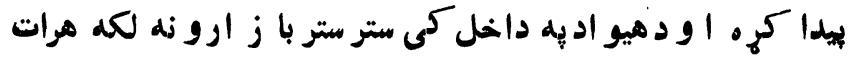

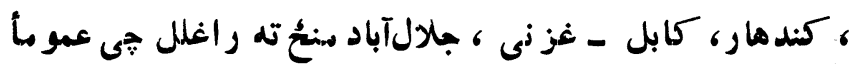

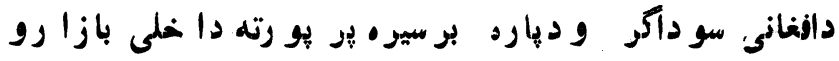

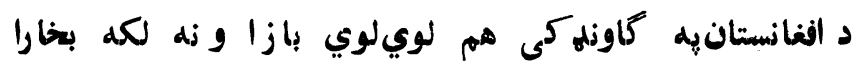

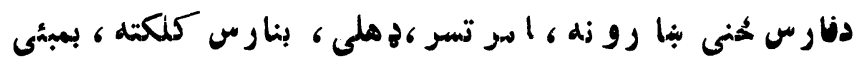
6ملتان ،لاهور، كو إجى، اونهيندي اونورعمده مركزوزهبلل كيدل .

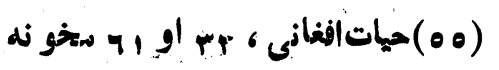

$$
\begin{aligned}
& \text { - mo- }
\end{aligned}
$$




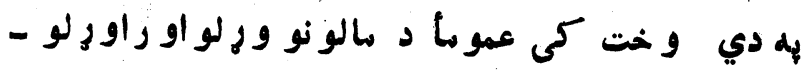

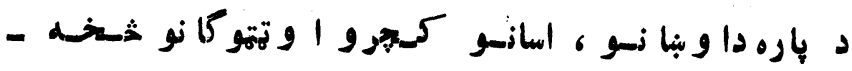

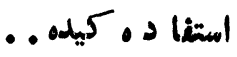

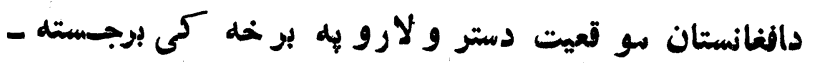

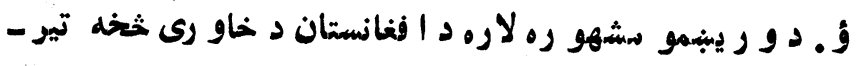

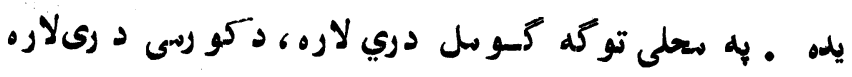

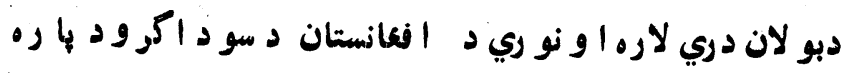

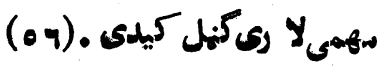

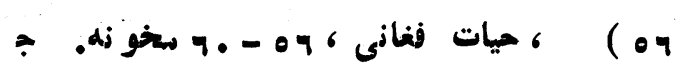

$\times 4-$ 


\section{دريمفصل}

الف:د افغاناوسكس دو لتو نو كشمكث .

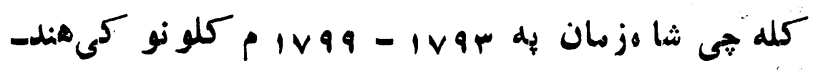

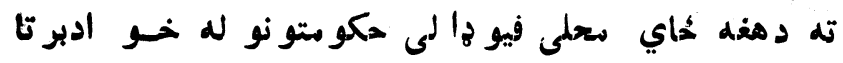

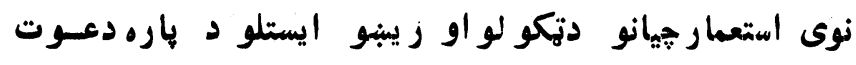

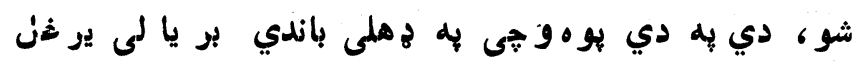

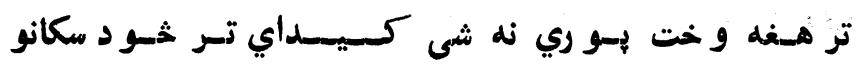

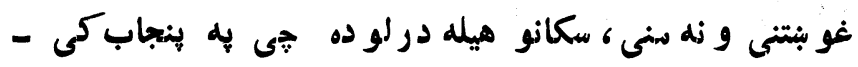

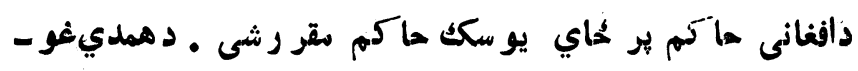

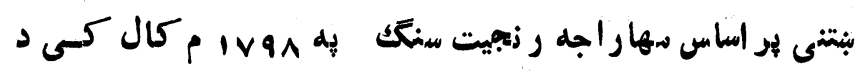

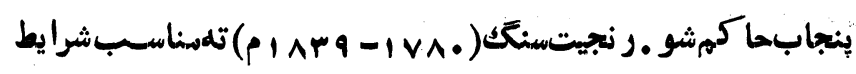

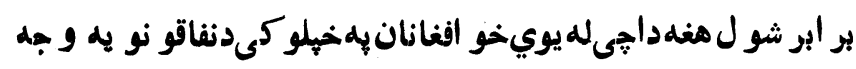

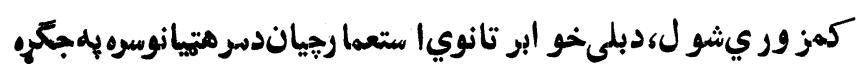


كى وو رنجيت سنكك ثز رو كره اي شول جهى لو سري دافغانانو -

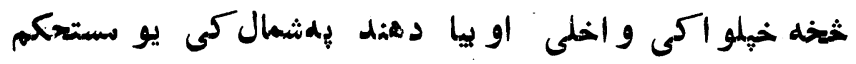

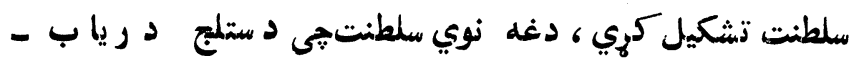

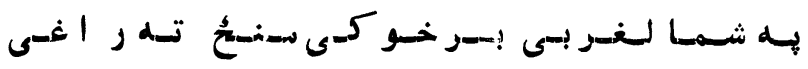

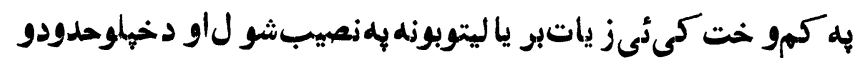

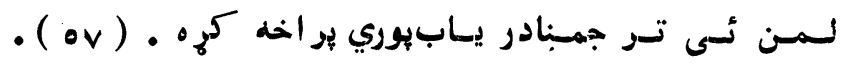

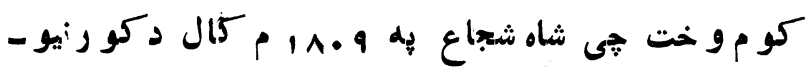

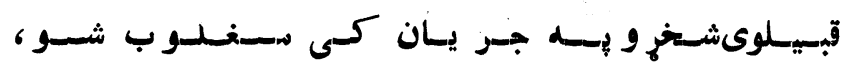

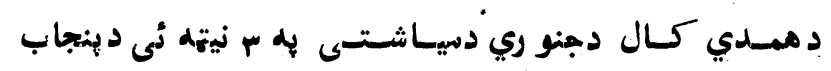

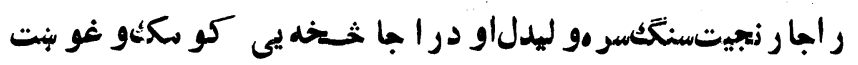

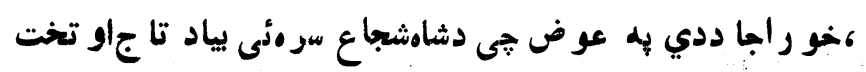

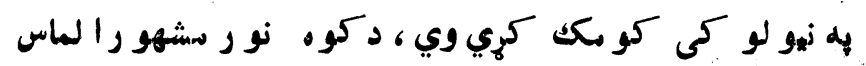

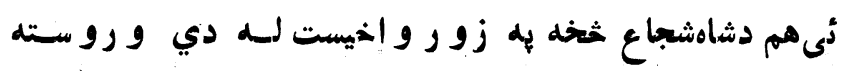

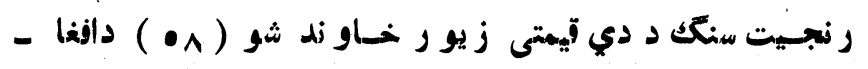

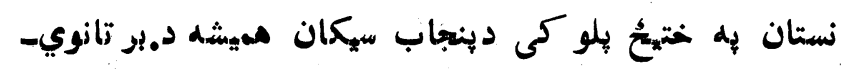

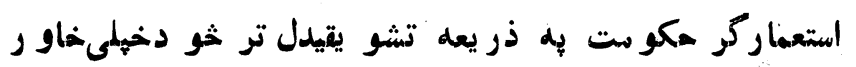

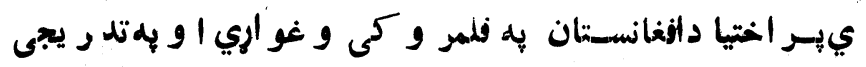

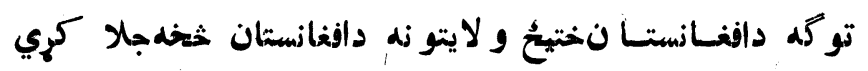

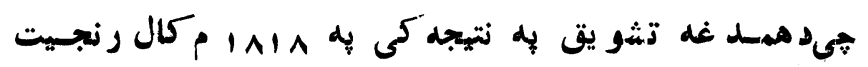

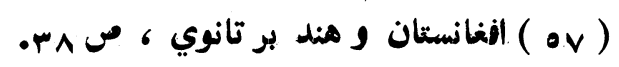

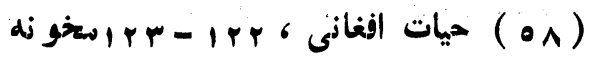




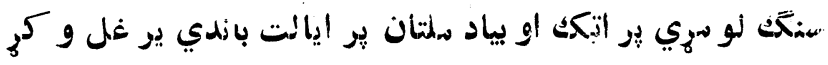

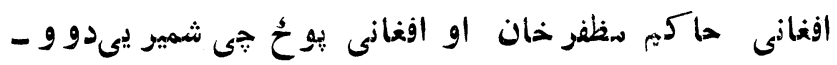

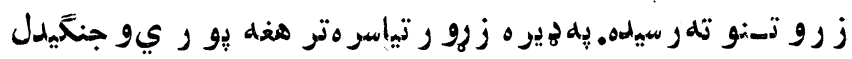

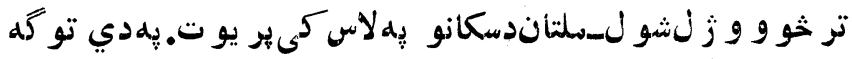

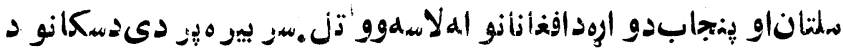

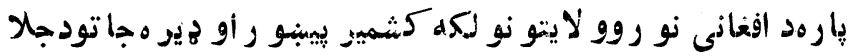

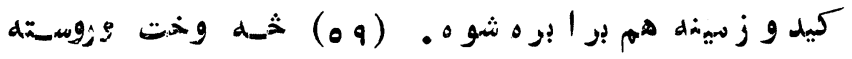

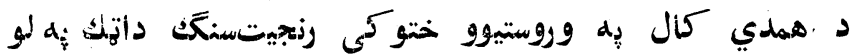

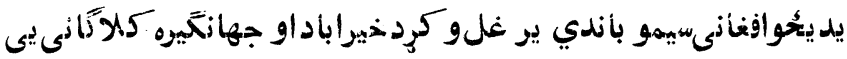

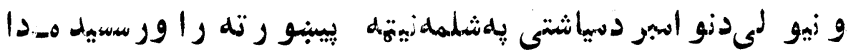

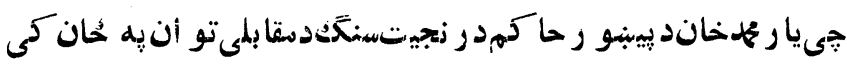

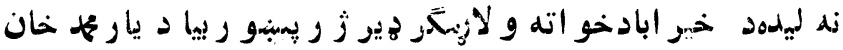

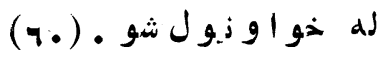

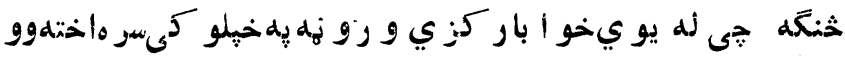
د بلىخو اسدو ز ي شاه شجاع همد تاج او تخت دبيو تهلاسته را

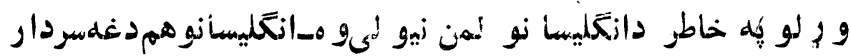
د .

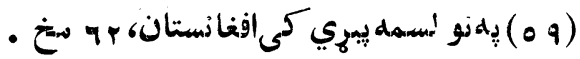

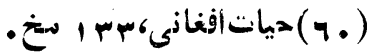




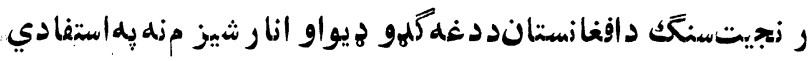

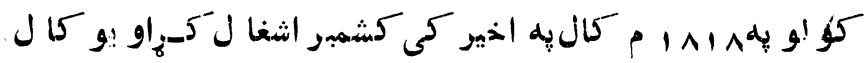

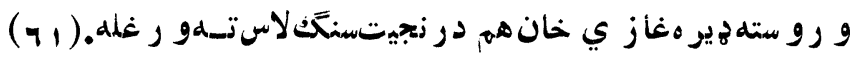

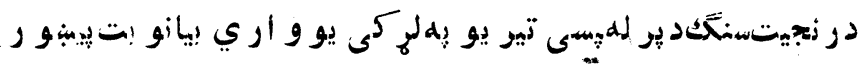
تلهو رسيدياز محمخاند يبينور حكمر ان دكابل خخخه كو ملثو غو نبت

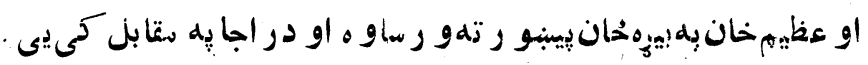

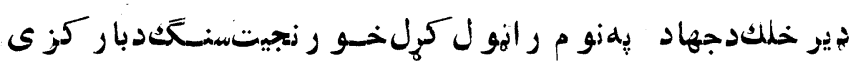
و رو نو تر دنئ بهنفاف أجو نو بو يالىشو باركز ي إيبنو ريو رو نزه

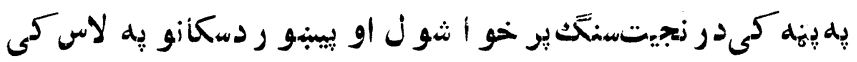

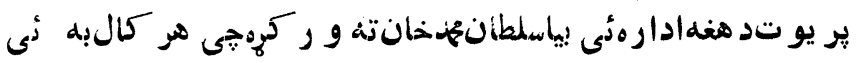
دبنجابسكانو دو لتتهماليه و ر كو له ـ ( ب بـ ).

s:

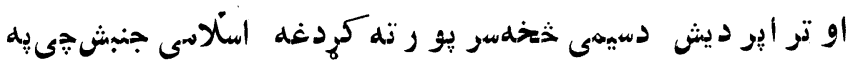

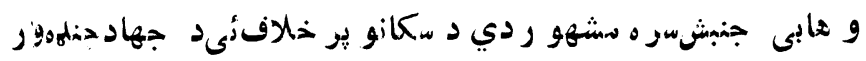
بو له، بيبنو ر او دهغله بناو خو اسيهى يى بيادسكانو خخهاز ادي كري

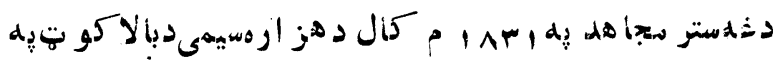

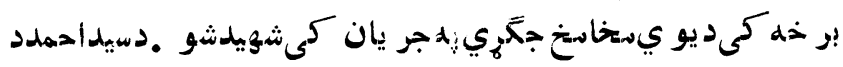

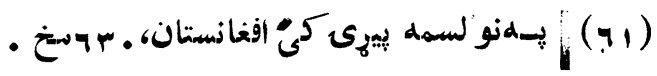

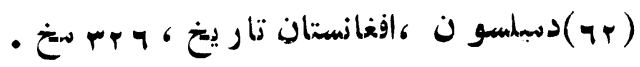




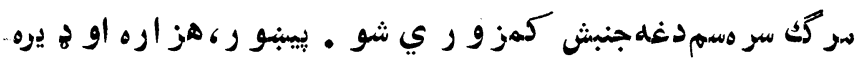

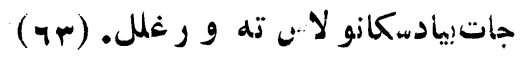

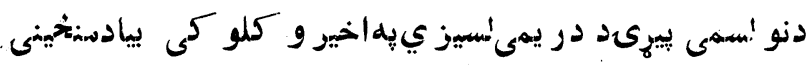

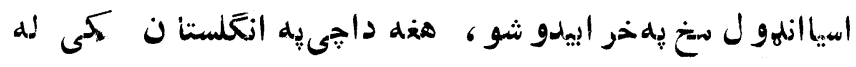

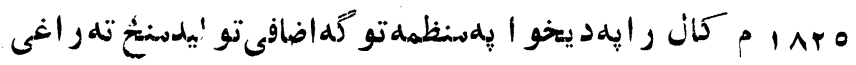

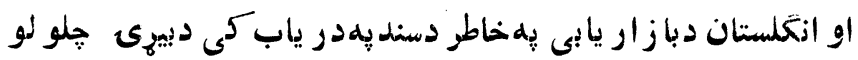

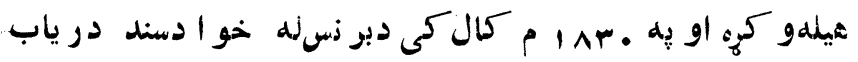

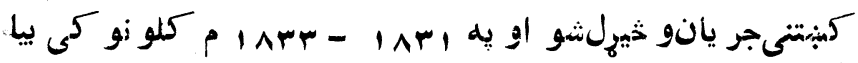

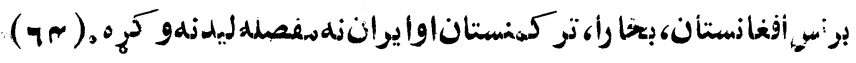

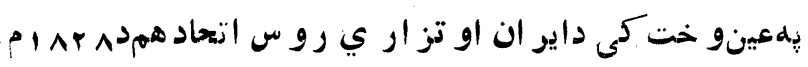

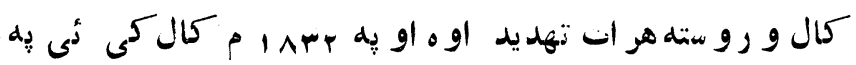

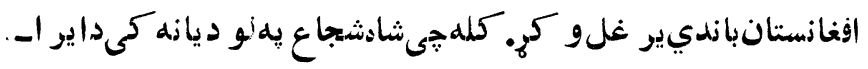

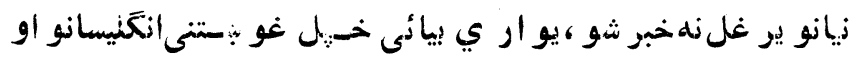

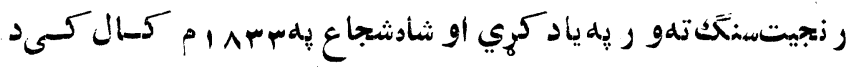

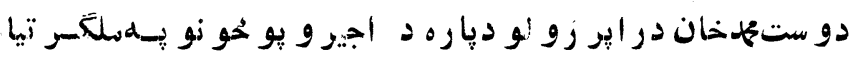

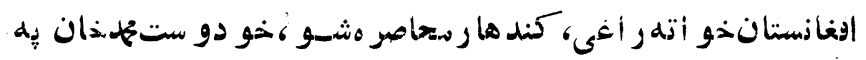

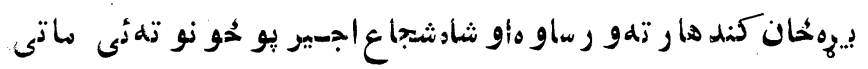

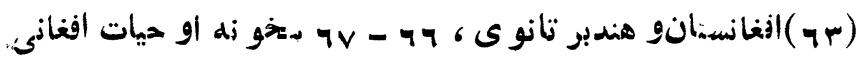
س

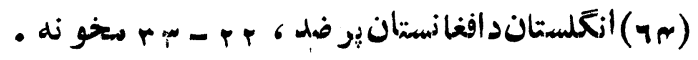




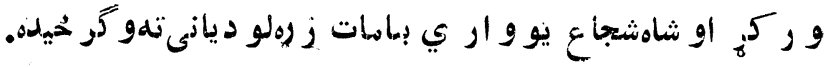

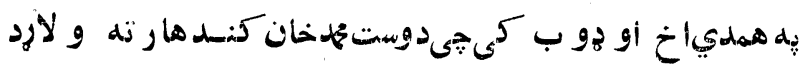

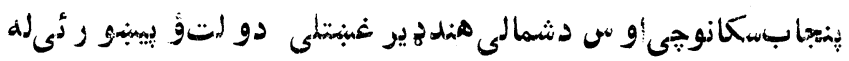

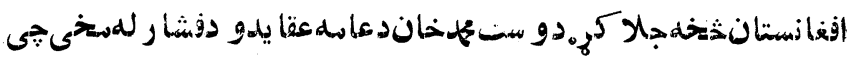

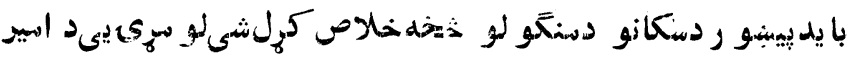

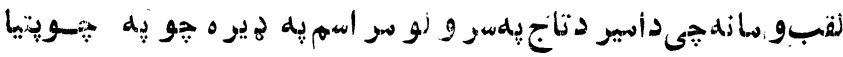

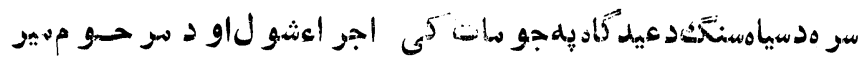
و اهظد زو ي بِهذر يعلد در أنى احمهشان دتاجبو شىيه بيرو ويد

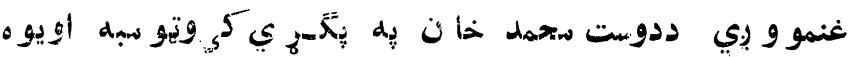
اندازه نوى بيسسى جیى دده بِلنو م ضر بشوي وي بـهدو ستهيحمد خانبائدي و ش.ند ل شوي حاضر ينو جى شمبر نى انيبر و و ت-بيعت

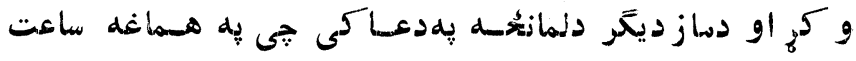

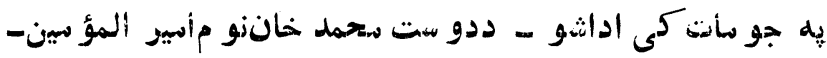

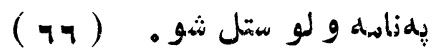

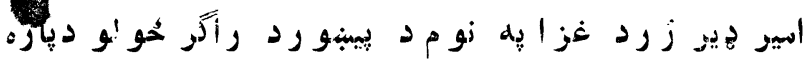

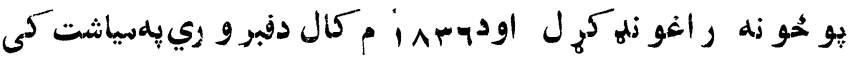

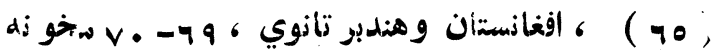

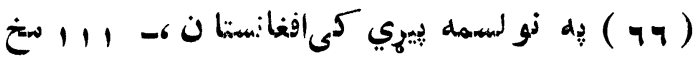


جلال آباد خو اته رو ان ثو. ادير دكابل زه دخيل حر كت -

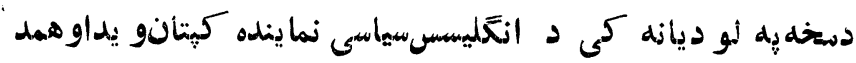

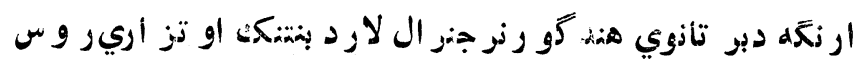

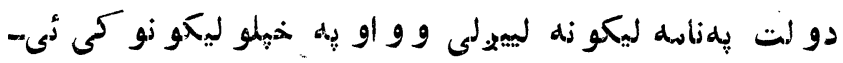

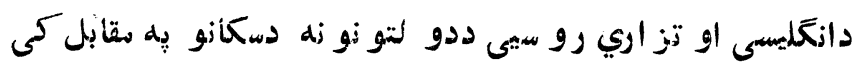

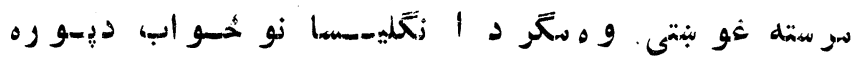

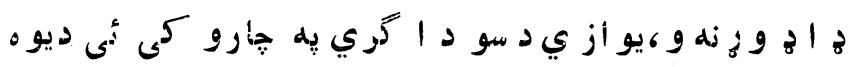

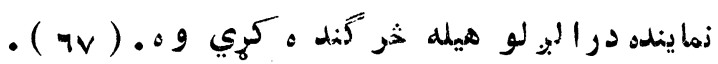

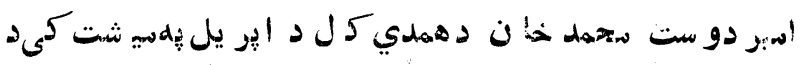

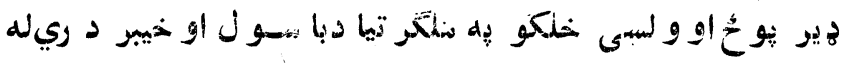

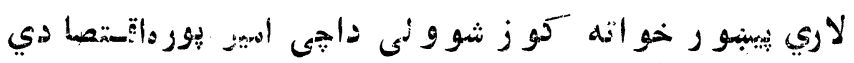

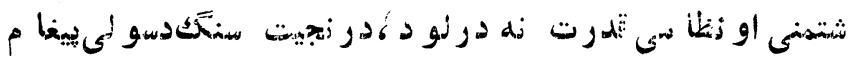

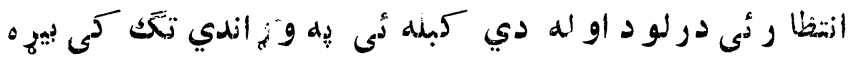

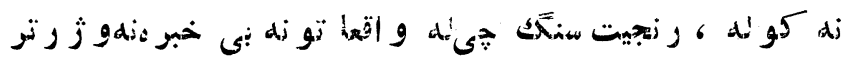

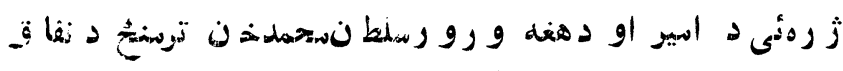

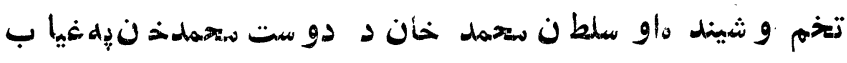

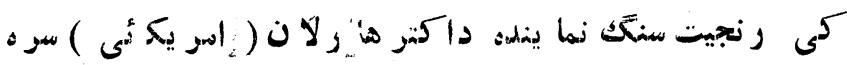

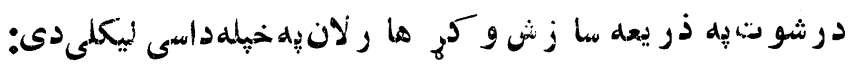

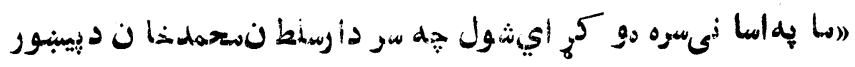

Afghanistan, past and present, Moscow, 1982 P. 100 


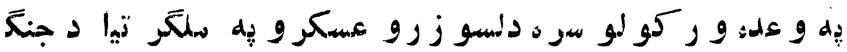

$$
\text { ... ( }
$$

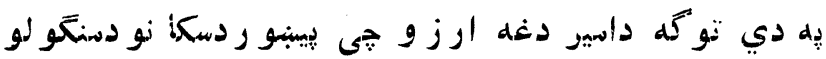

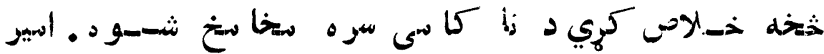

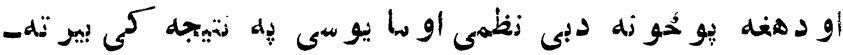
لمو دزي جلالآبا د او بيا كَ بل خوانه رواوكر حيدل .

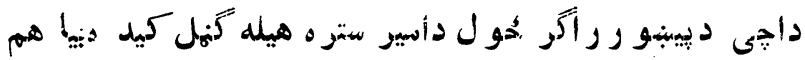
البير

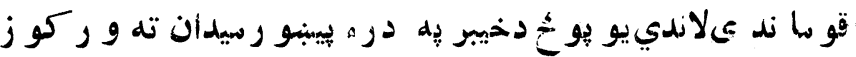

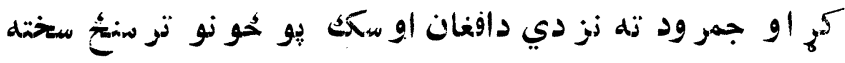
جَّره بيبنه شو ه سكانو سختلة سأتى و خو هه او ددوي ستر جنر ال

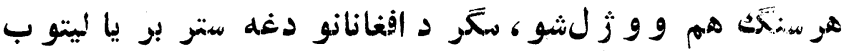

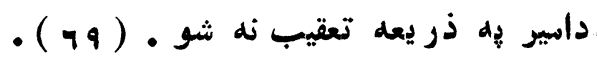

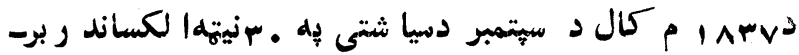

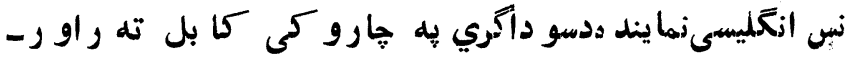

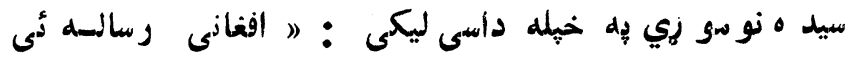

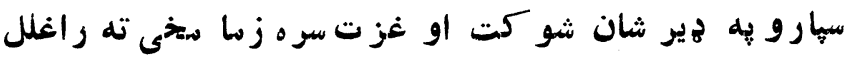
جى د امير صاحب دزوي اكبر خان به قو ما ند هكى و و هغd

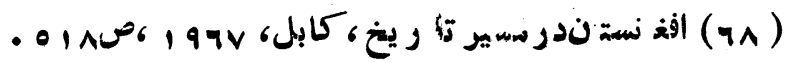

Louis Dupree, Afghanistan, P 363. 


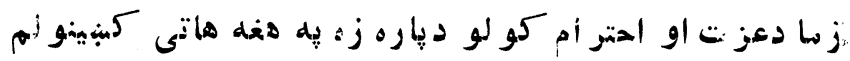

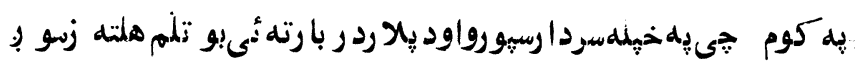

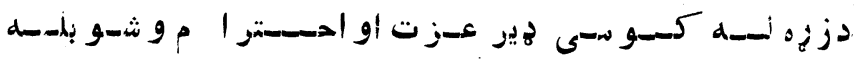

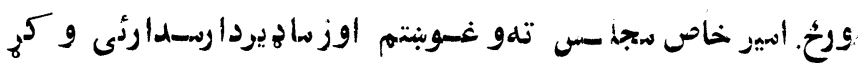

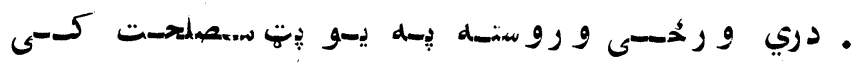

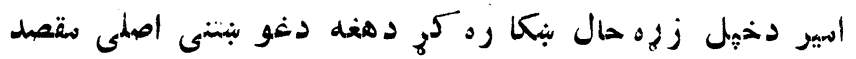

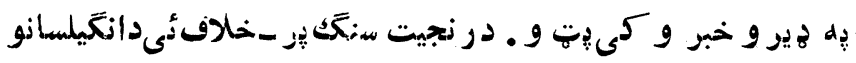

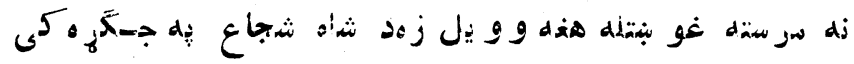

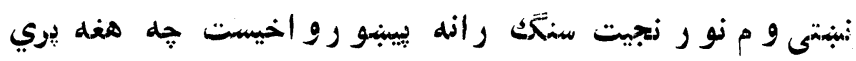

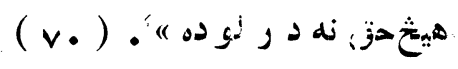

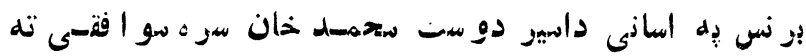

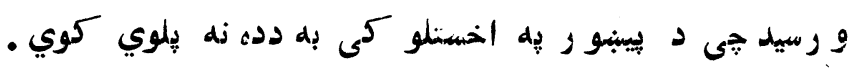

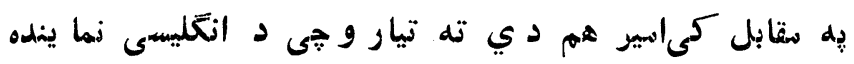

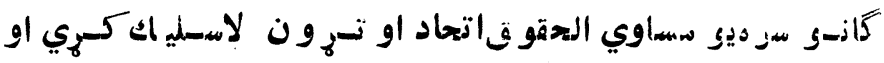
افغانستا ن تمه د اثتخليسى ما لو نو دو ارد ولو د بارهمرسته و كري نو.مو ج ي د سو افقى د لا سليك دا جازيديار ه لند ناو كلكتى و اكمينو ته ستركى يه لارثه وه ثله وخت ورو سته دبر

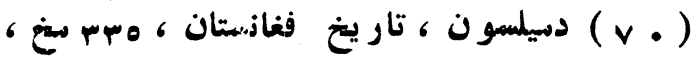




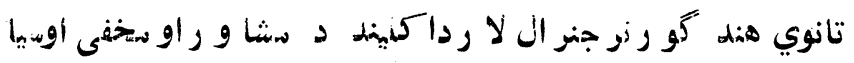

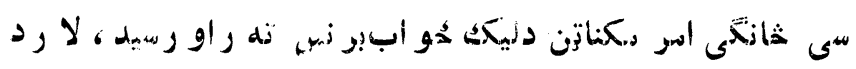

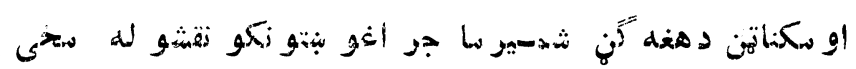

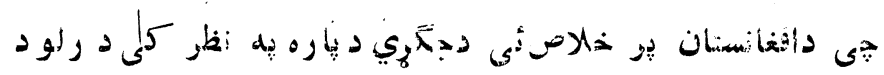

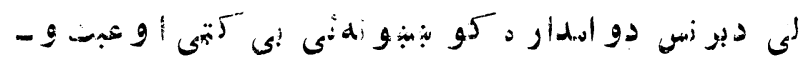

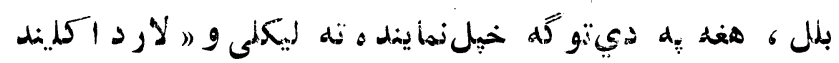

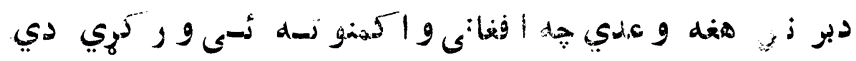

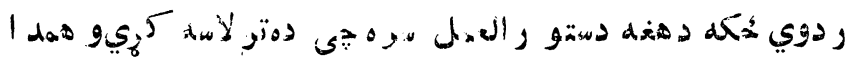

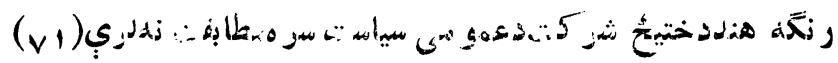

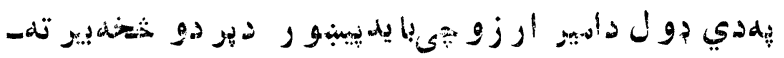

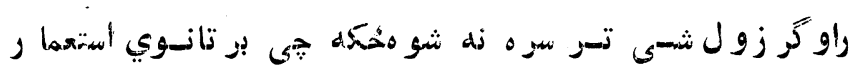

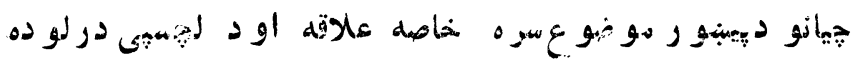
، هغه به دي شان و. جى د لندن او كلكتى و اكمنو د ينّجاب

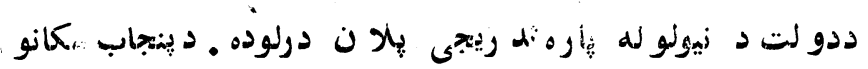

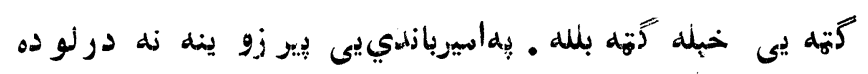

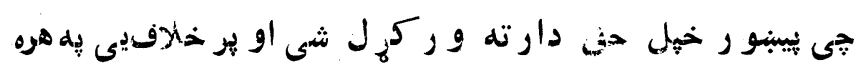

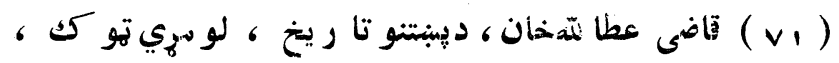

$$
\text { كابل ، }
$$




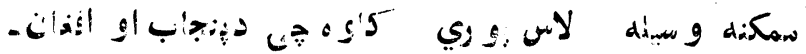

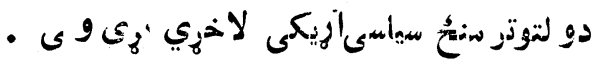

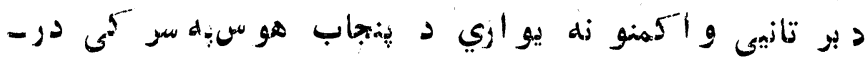

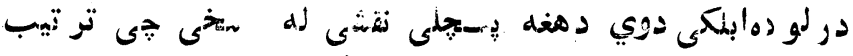

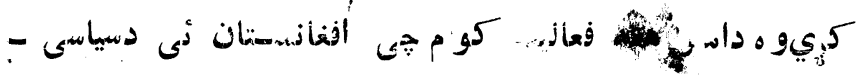

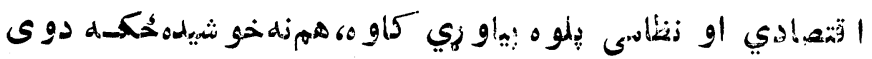

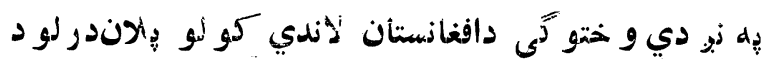

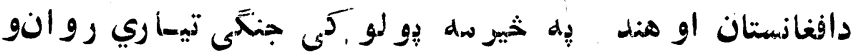

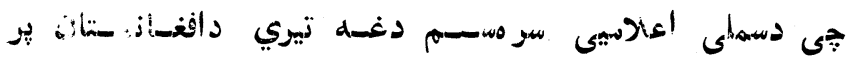

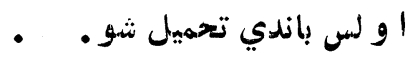

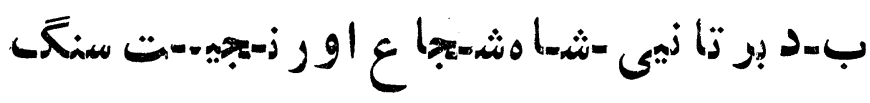

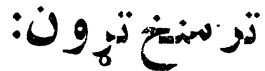

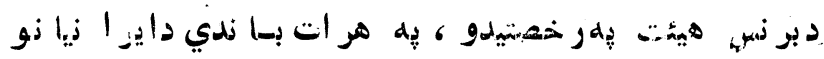

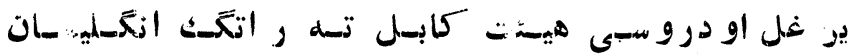

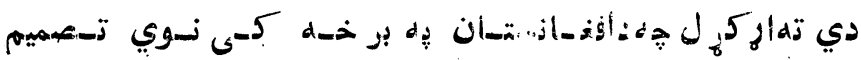

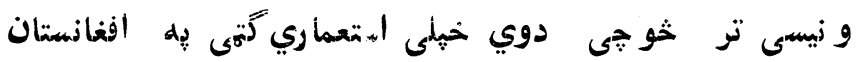

او يه سيمه كى و ساتلاي شى .

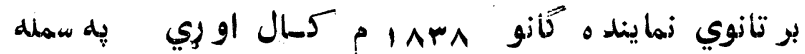

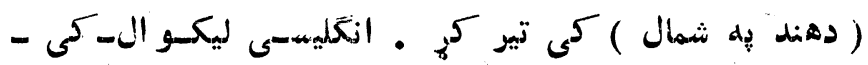

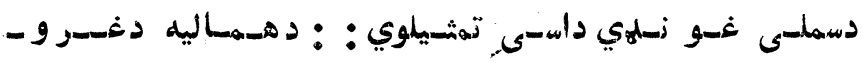




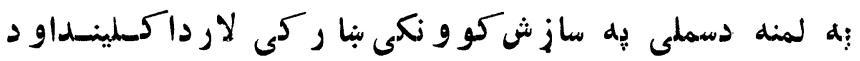

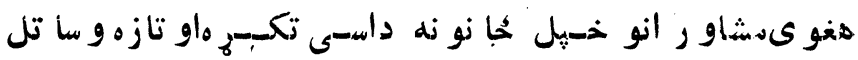

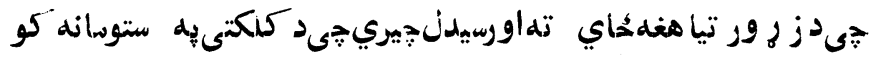

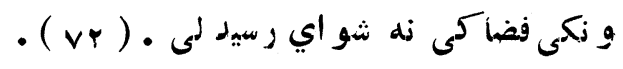

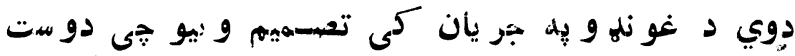

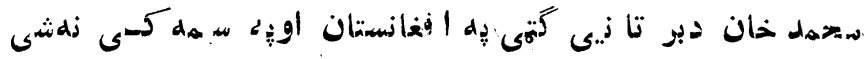
ساتلاى نو دده بِرحاي بايد دأسى خو كف انت-خاب او ير تنخت

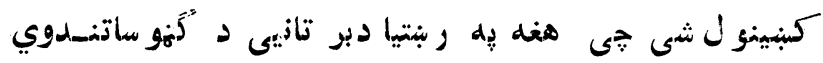

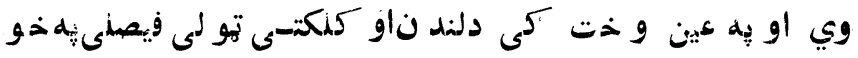

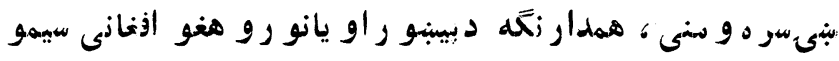

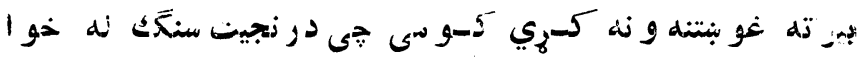
نيو لشوي،دي ـ البتهل د دي شر ايطو سوه هويو مو افتخى او سنا سب

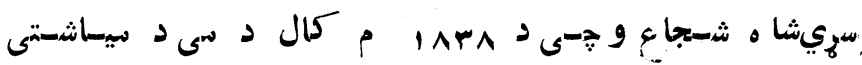

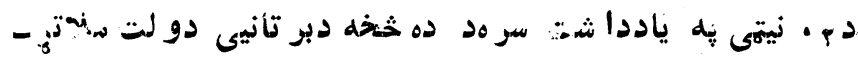

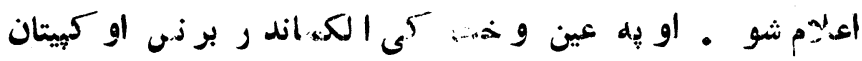

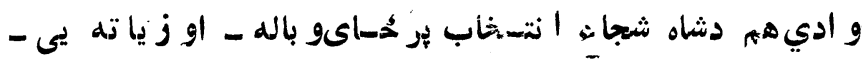

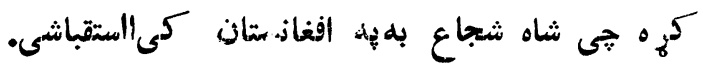

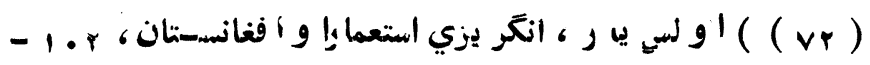

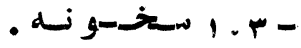




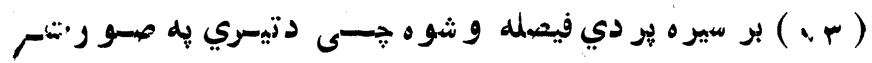

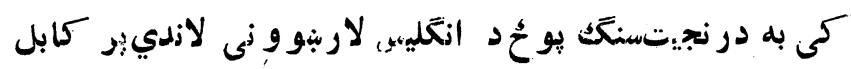
ير غل كوي او دهمكاري يه خاطر بلدشاه شنجاع تو قو ساندي-

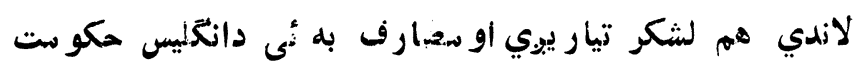

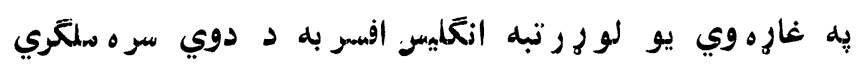

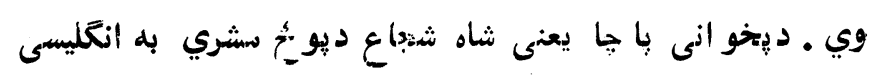

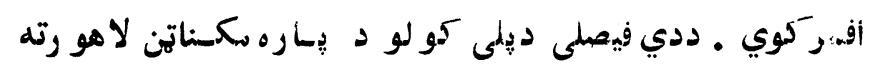

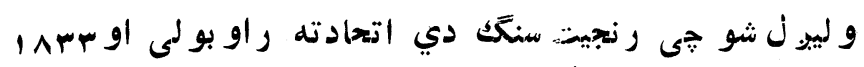

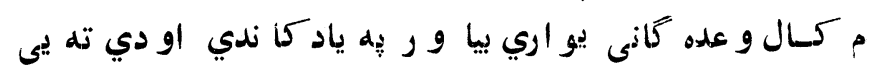

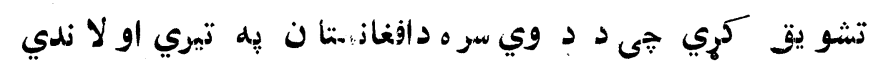

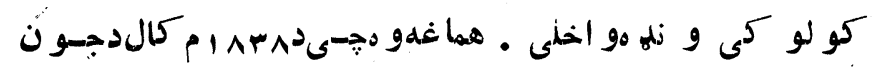

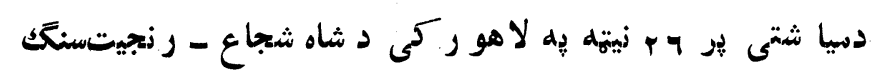
او بر تانيى تر سنغ دري الخيز تي و ن يه م 1 مادوكى لاسليسك

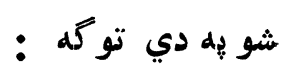
1 - شاه شجاع دخهل خحان خهلو و ار ثانو اوخبلو جانيشينا-

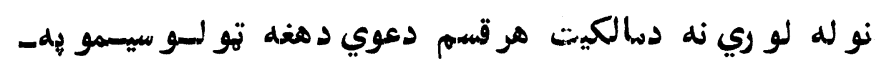

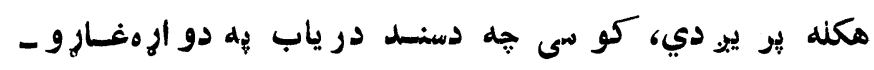

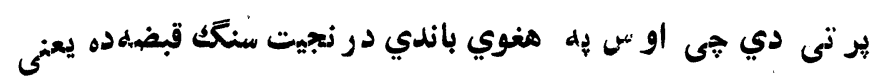

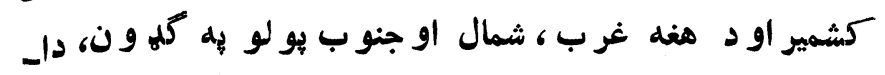

افغانستان و هند بر تانوي ، ص 11 ( Vr) 


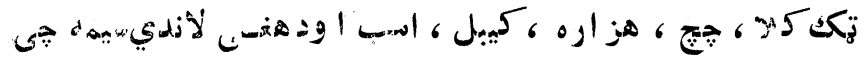

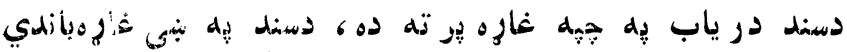

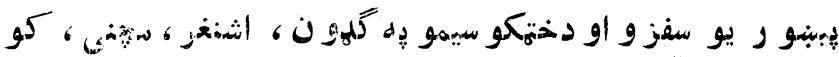

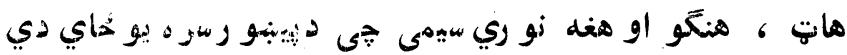

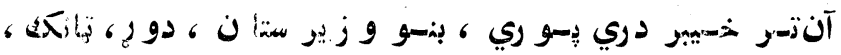

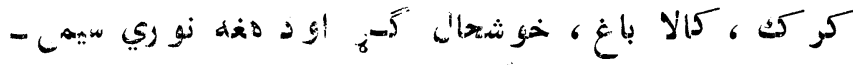

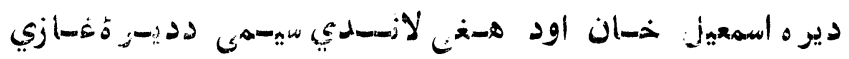

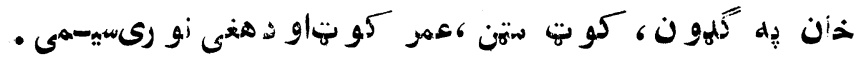

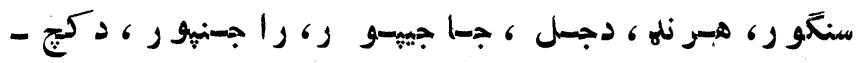

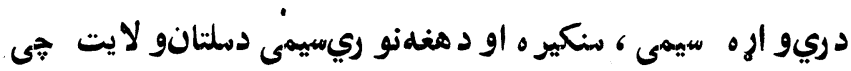

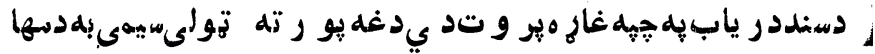

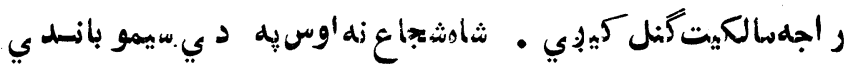
خله تعلقلوي او نهبلئىر اتلو نكى كىو لري ـ دابهد دههار اجهاو د هغله

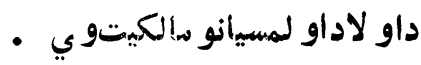

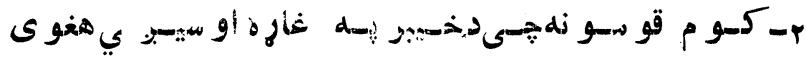

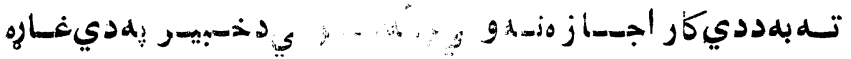

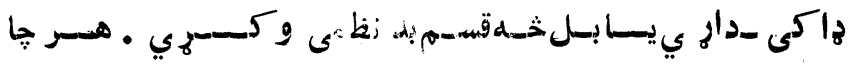

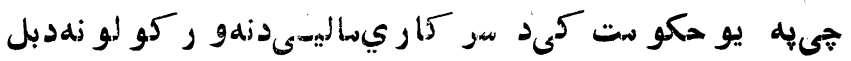

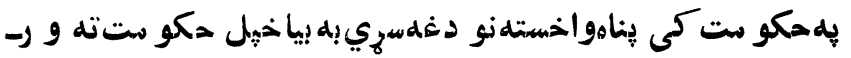

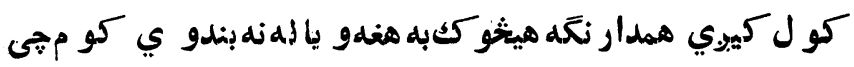




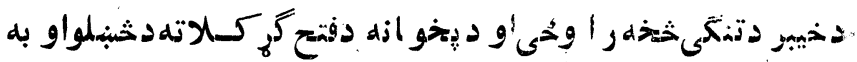

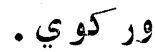

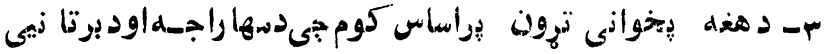

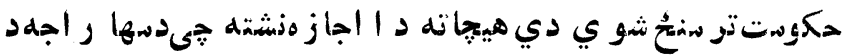

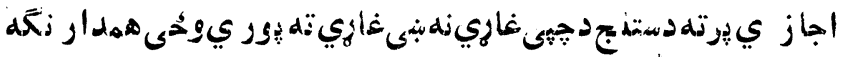

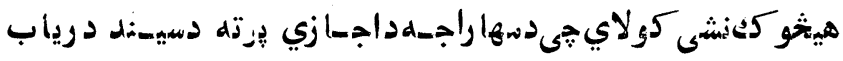

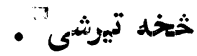

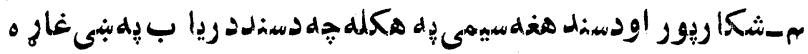
يرتهد م هر هغdجا يز ه او سناسبه: فيصلهجى دسر كلادويلهاوسهار اجه

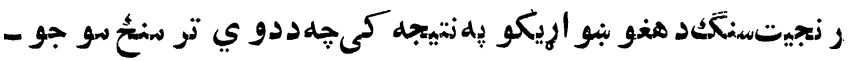
دي دى .و شو مـشاهته به هغdفيصلمهنظظو ره او دهنلو ورو ي .

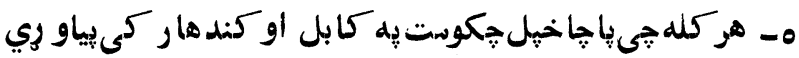
كرينو هغdبه هر كال سهار ا جهته دنهلانديشيان را ليبوي:هـ

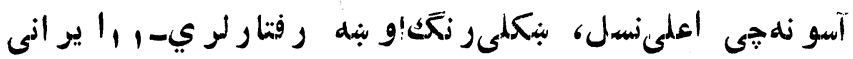

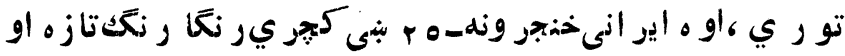
و جیى نيو يسو دي يأسشكىخو ابره اوخو ندو رختكى (دابلتو ل كال ر الييول كيري).داشييانبلد كابلد در يابلهلار ي يبينو ر تهر را ـ

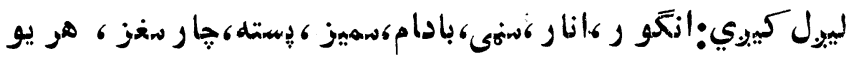

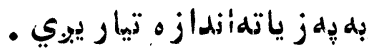

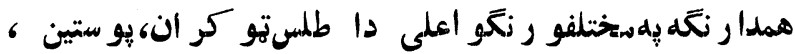
كمتخاب، جىدسر و او سبينو ز رو كار بر ي شو ي و ي،اير انىغلى، 


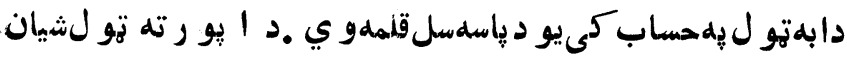
به باجֶا هر كال سهار اجهتهر استو ي .

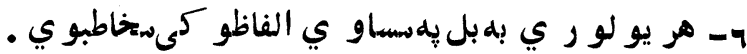

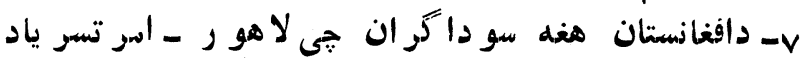

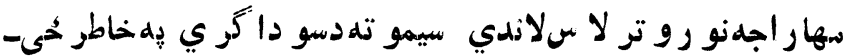

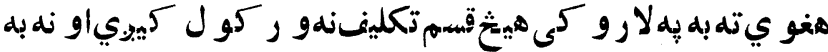

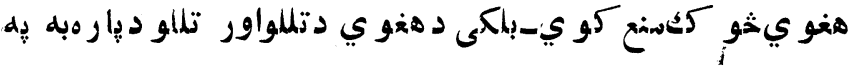
جدي تو گهاسانتياو ي بر ابر يوي..هار اجهو عد هكو يجى هغهبه هم يهدي تو كلهدا فغانستنان هيو اد سر ه خهل جلنهاو رو يلهسا تى.

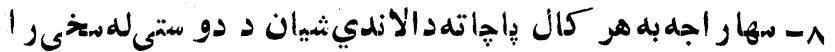

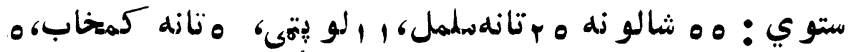

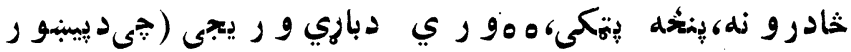
ميخصو ص ييداو ار دي )

ه - كdجيو ي دسهار اجه كو م افسز داسو نو يادبل كو مشسى

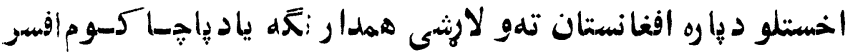

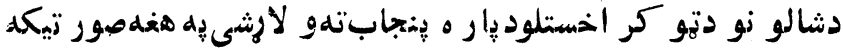

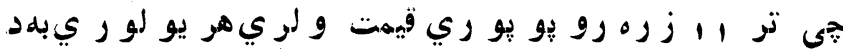

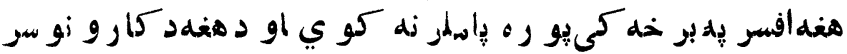

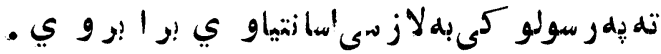




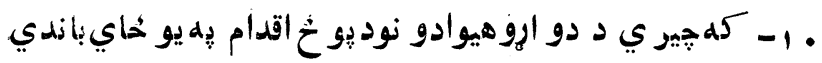

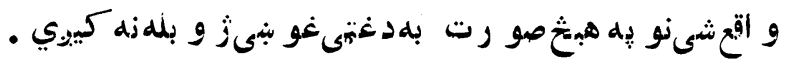

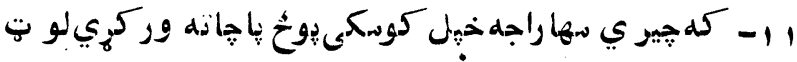

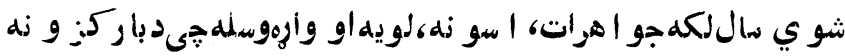

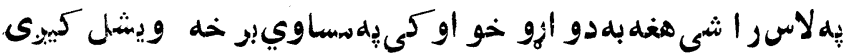

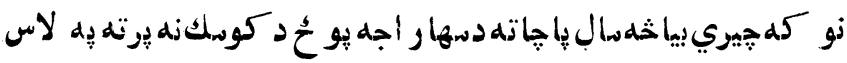

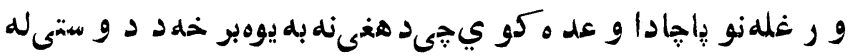

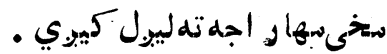

r ا - دو اله ه لو ر ي بله ههيشه يوبل تهخبل سفيراند سندو نو او تحفو سره ليبزي •

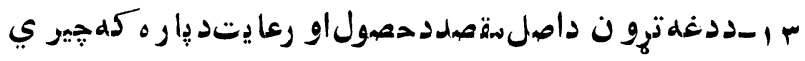

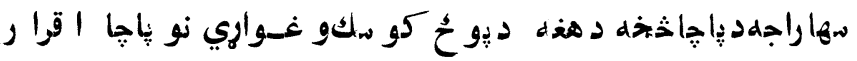
كو يجىز هبهدإيو حُ دخبل يو لو ي افسر دقو ماندي لاندي هغه

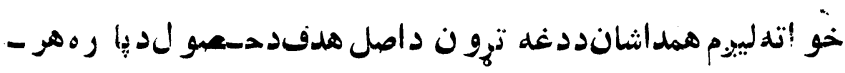

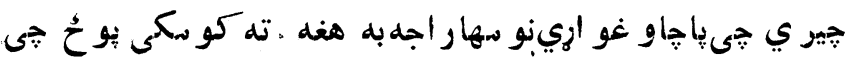

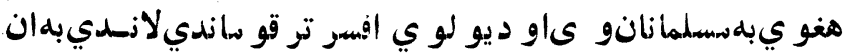

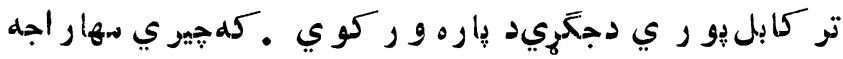

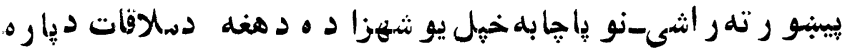

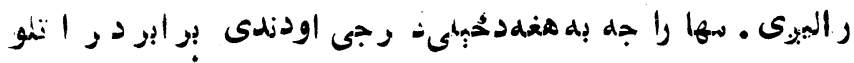
ا ود رخصتيد و به وخت كىبنهعزت كوى . . 


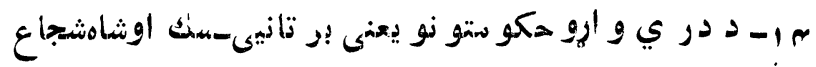
دو ستانبهدو ستان او دينهنان بهديو بل دبنهنان أو إوي .

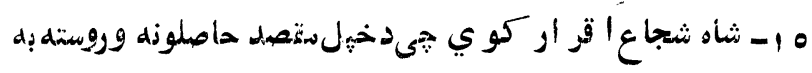

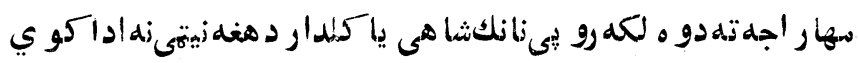

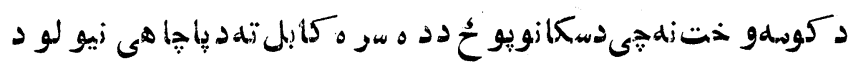

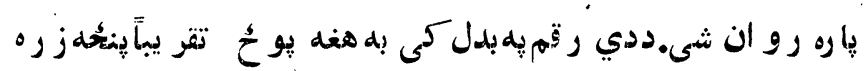

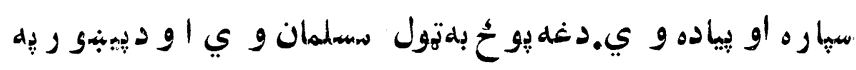

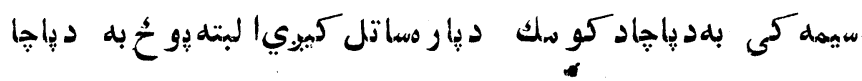

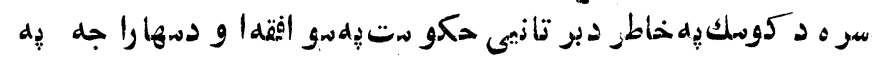

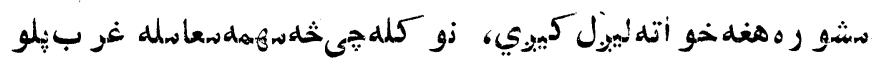

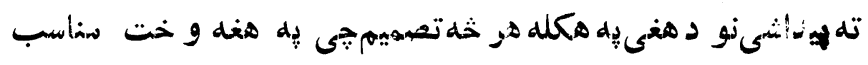
و ي د بز تانيىاوسك حكو متو نه بلى عهلى كوى ي . كلهبير ي

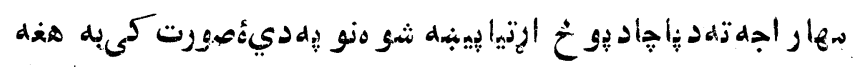

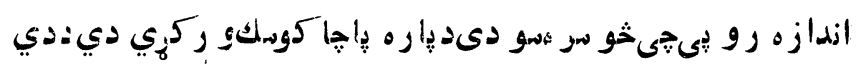

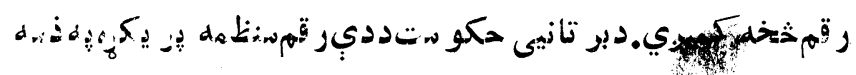

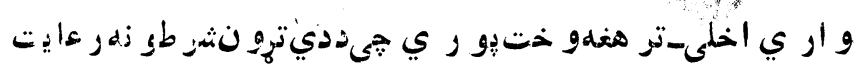
او ساتسل ك-ميوي .

19

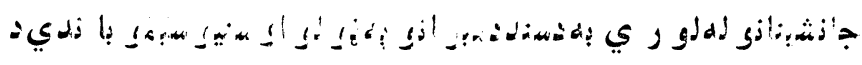

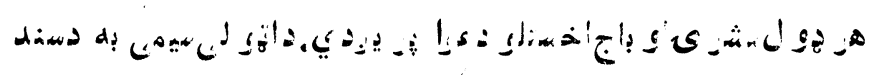

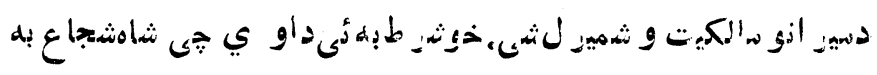




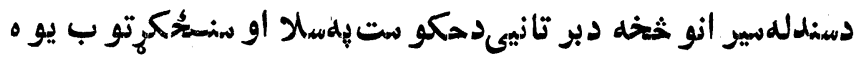

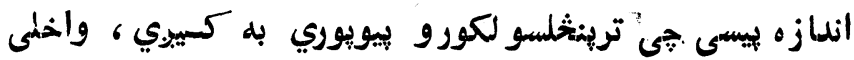
او هغdبd مهار اجهر نجيتسمغكتهور كوي ـ كلهجى داييسىو ركرا ي شو ينو د سبر ا م كال دمارج د د ا نيتهىتو و نخلو رمه ماده سنسو خُنهل كيبي.او دسهار اجهاو دسندسيو انو تر منئ بسه د.

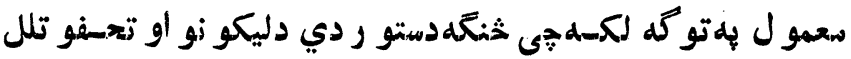

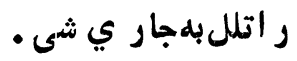

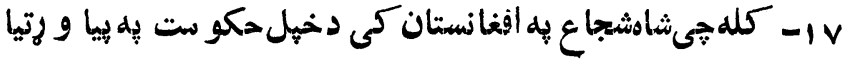
بريالىشىنو هغdبلد هر ات بهحكومت باندي يو غل نه كويا ونه

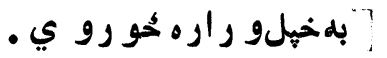
^ ا سشاهشجاع دخهلمحان دخهلووارثانو اودخهلوجانشينانودلوري

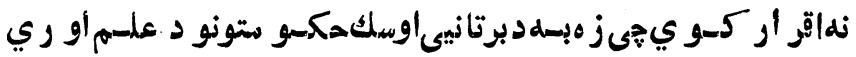
او سنظو ر ي بر تهبل كو م حكو ستسز هترو ن نه كو م او زه بلدد هر هغلحكو ستسقابله كو م خيى يلزو ر باندي د بر تانيىا و ياسك برحكو مت باندي يو غل كو ي .در ي واره حكو متو نهيعهنى بر تانيه6مهار اجه ر نجيت سنغك اوشاه شجاع دترو ن له بو ر تهشر طو نو باندي متفقدي او يهخو بنى باندي ئى دنى • ديو ر تنيو ذكر شو و شرطو نو او مو ادو خخخه بله هيخكله انحر اف نه كيبرياو دا

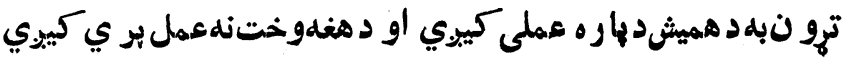




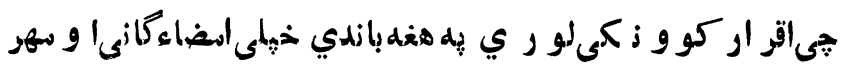

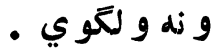

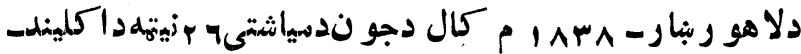

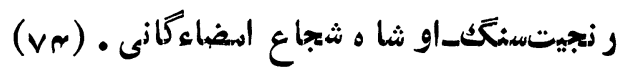

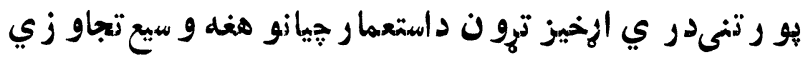

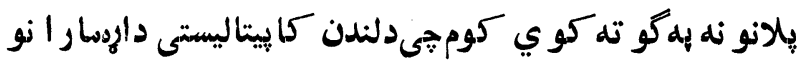

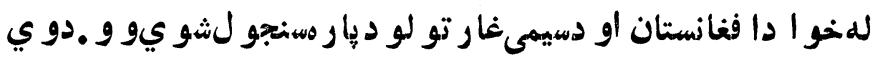

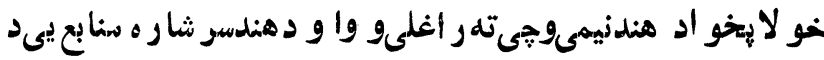
كلو نو كلو نو راهيسى ديهغار تكرا نه تو كه استثمارو ل . كال

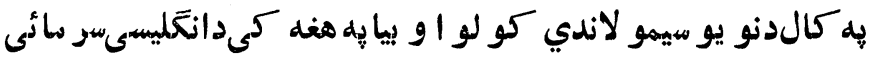

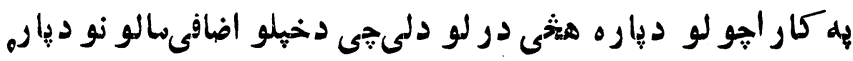
دخر خلاو بازارو نه بيداكريا و دنو رو الستثمارو لو ديار زمينه

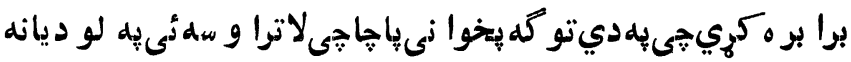

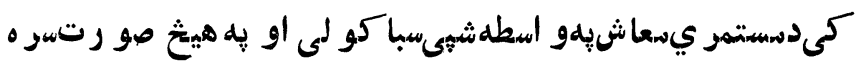

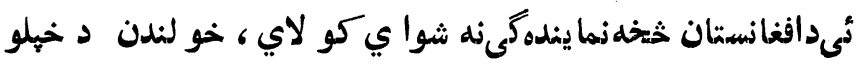

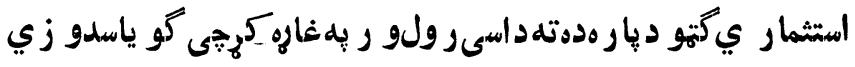

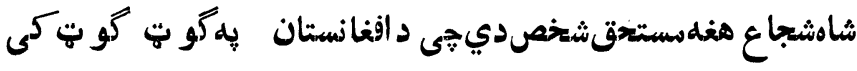

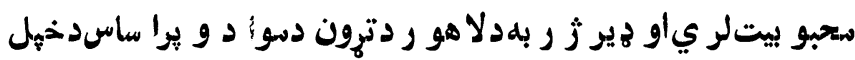
هلار نيكه به تخت كنينى .

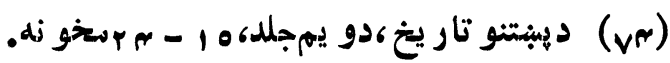




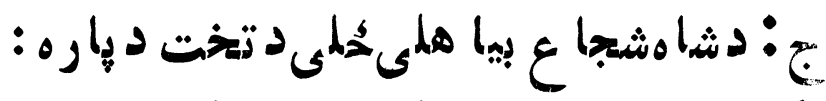

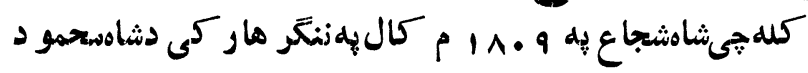

دلاسهماتىو خو رهنو دكندهار خوا ته و لاه او خلوربياشتىورو سته

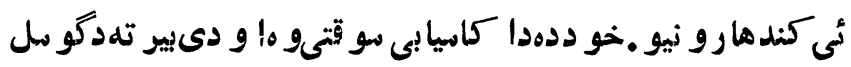

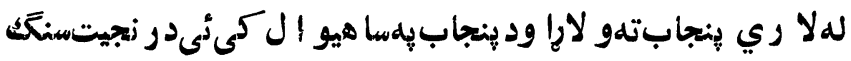

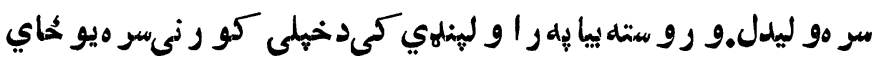

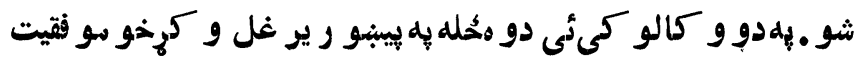

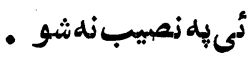

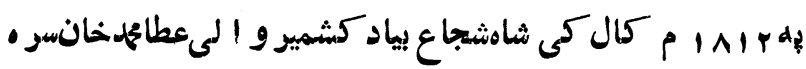

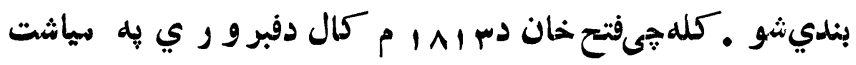

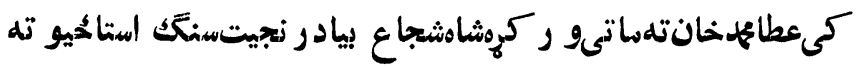

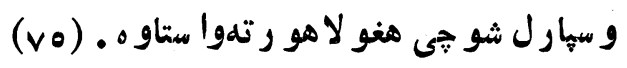

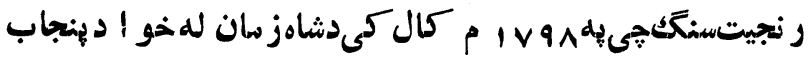

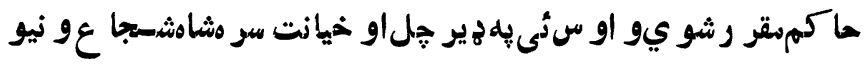

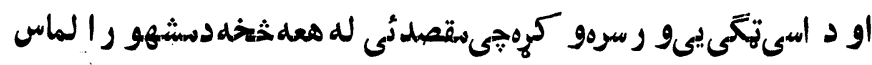

$$
\text { كو منو ر تر لاسه كول و و. (v ) }
$$

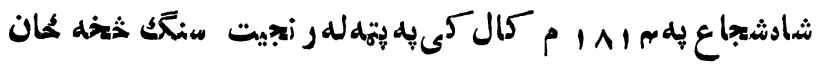

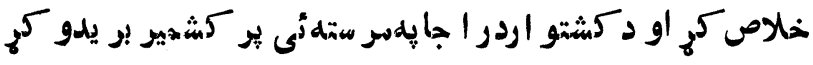

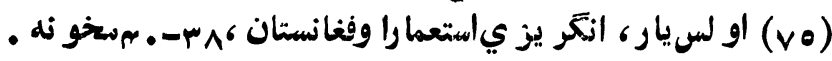

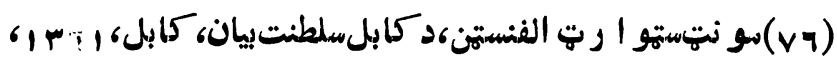

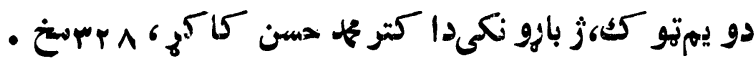




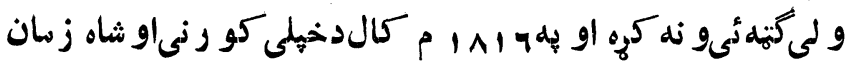

$$
\text { (vv). سو هيهلو ديانه كى يو محاي شو }
$$

يهمس 1 م كمال كي دشاهشجاع خو ب او خيال بياعملى جنبه هيها

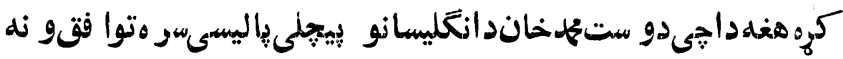

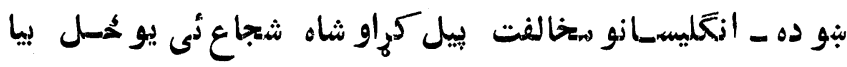
دأفغانستان نيولوته تشويق كراود أنكليسسياسيىنما ينده كيتانويدله خوا

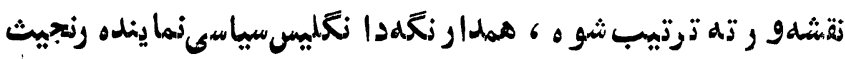

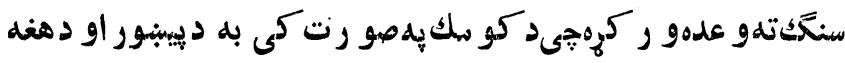
نو رو كاو نله يو سيمو مستمتحق شى. دسو قياتو نيصا رفيى دگورنر

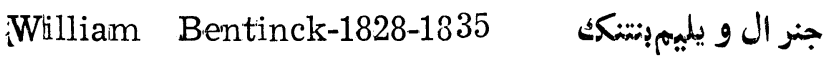

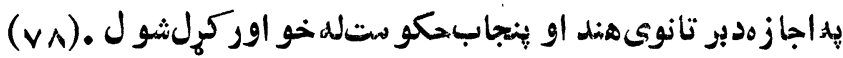

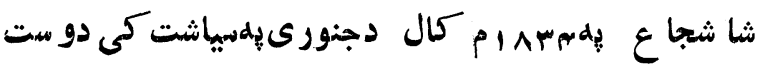

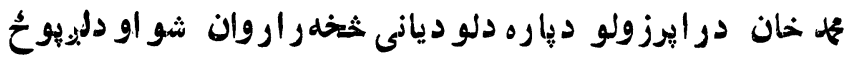
سو هداباسين خخله را بإوريوت او يهشكا ر يور كىئى د درا نى باجيا

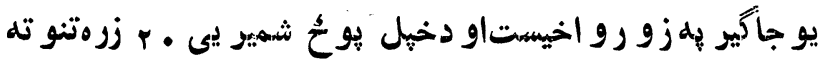

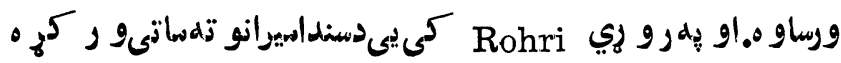

(VV) • • • • • (V^) 
او كندهار خوا ته راغى اود خوجك كو تلبهل درهكىيى كندلخان سات كي او كند هار ماحاصو ه شو .

دكنسدهار بار كزوورونهـود كـابل نسـهدخهـلر كشـريو رور

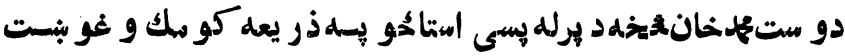

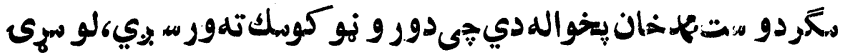
يه دانتليسانو نبضو نيواو خيل استأحى يىيهلو د يانه كسىدانكليسا-

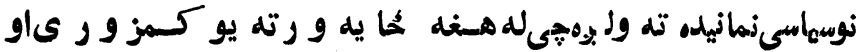

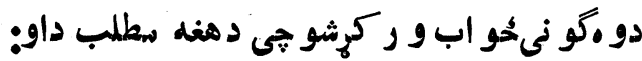

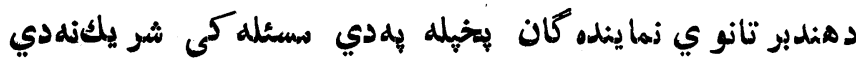

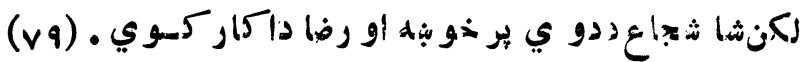

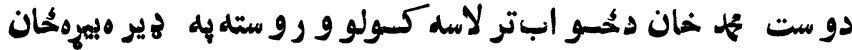

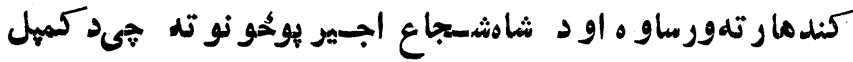
انتليسى افسسر تر قو مانديلاندي و و ماتى و ركرهاجير كمهل بندي

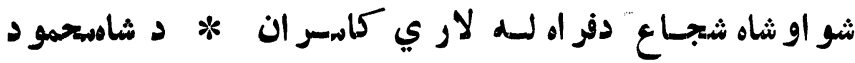

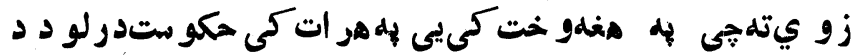
سر ستى به هيلمو لاريكتر هيو ز ربىله كو سىنتيجى اخستو ثخته دجو -

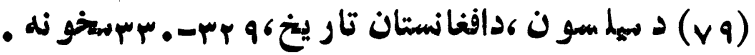

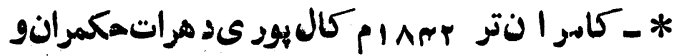




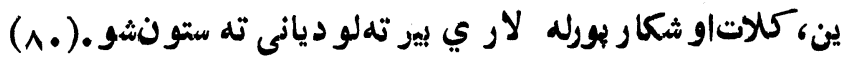

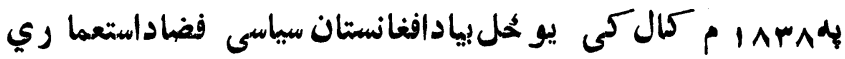

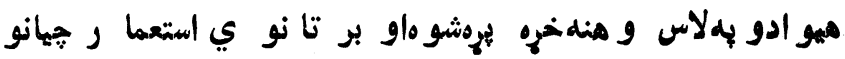

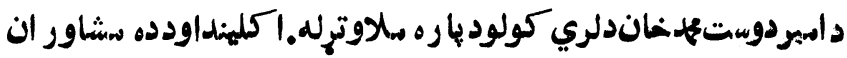

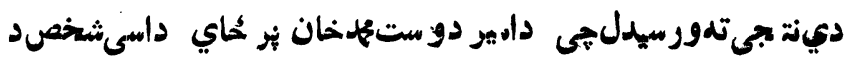
افغانستان ير تحتت كبنينو يجى هغه بهتول صداقت او فا د ار ي دد و ي دبلانو نو دعملى كولو سر د.و افقو ي اوبهعينموقع كى

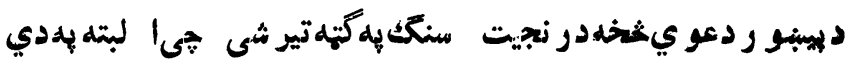
مناتو مو صو فسري هغdشاهنجاع و جى به لو ديانه كىو ر تلدداسى

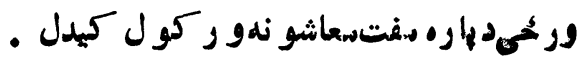

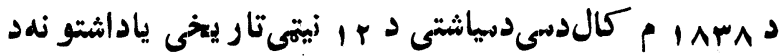

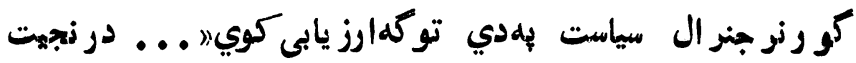

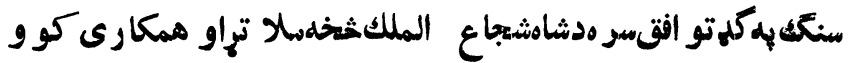

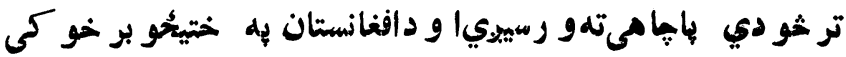

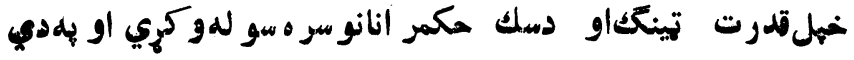

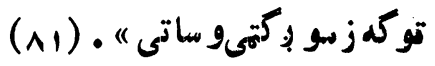

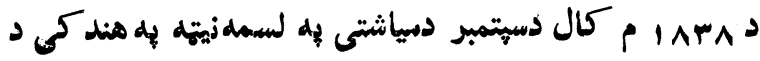
بر تانيى دلو او اعلىقو ماندان اسرصادر كُهيى د افغانستاندبار

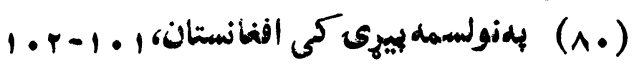
مانو نه .

(11) 


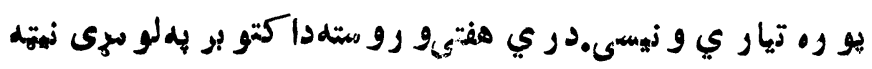

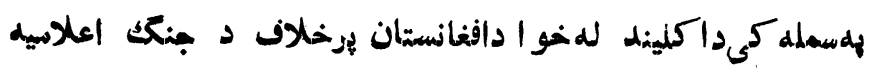

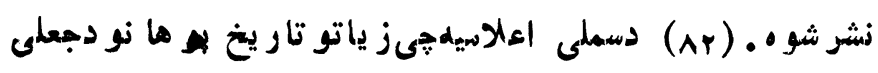

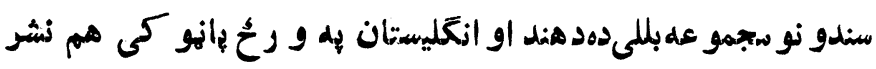

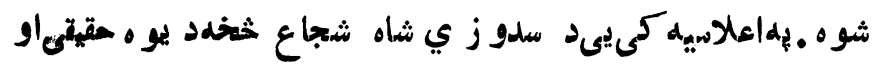

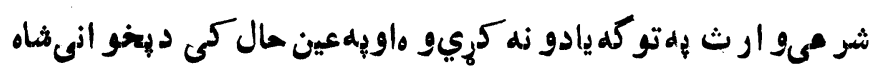

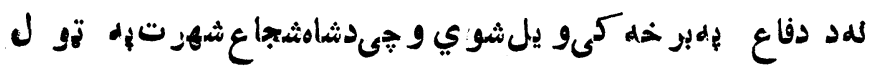

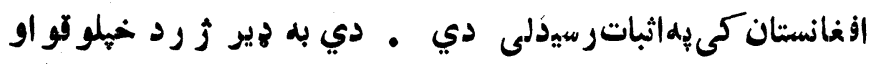

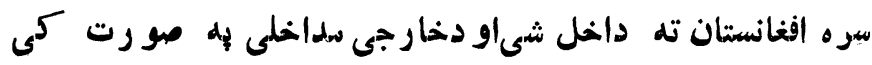

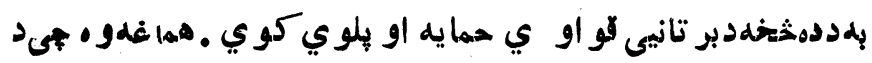

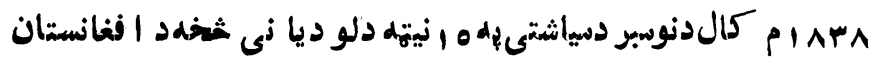

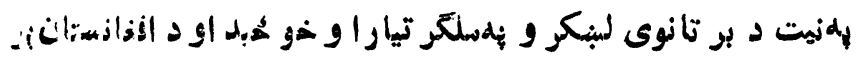

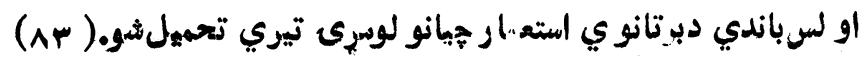

Arthur Swinson, North West Frontier, P 43. -(Ar)

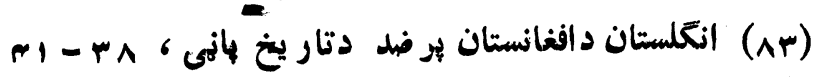
ميخو نه. 


\section{خلورم فصل}

الف : به هند كى بر تانوى استعهمار او د هغه تا ثير ات بر إ فغانستا ن :

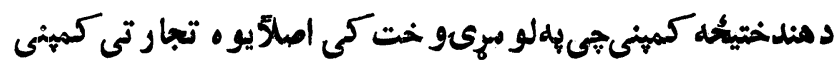

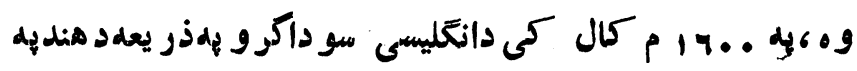

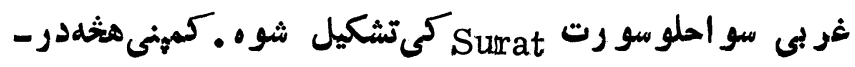

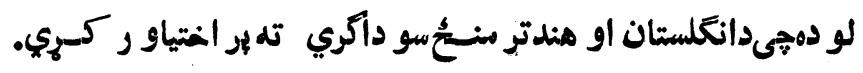

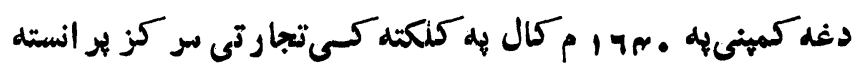

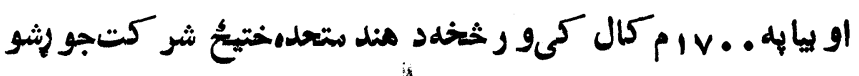

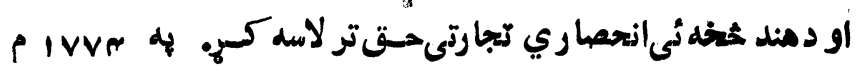

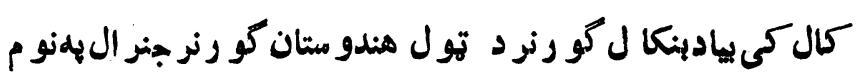

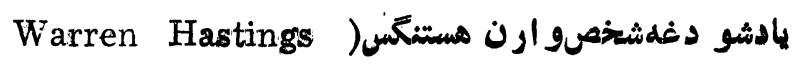

$$
. g(\text { inso-irve }
$$




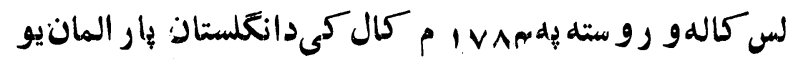

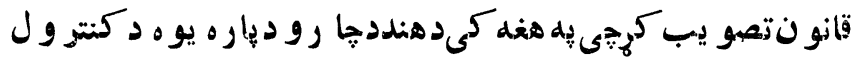

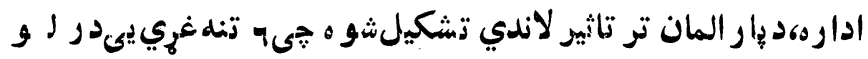

$$
\text { دل . (Ar) }
$$

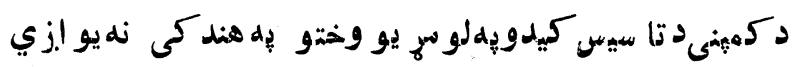
انعليساندسو جو دو و بالكى هغه هيو اد بِلساحلى بنار و نو كىىز ياتو ا رو بايىاستعدار كرو هيوادو امتياز ات ترلاسه كري و وه ـ خود هند

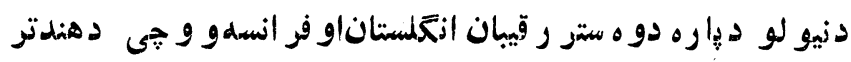

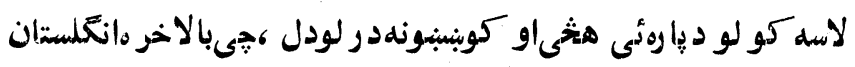

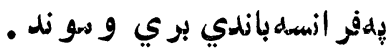

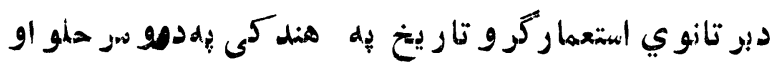

$$
\begin{aligned}
& \text { عصر و نو بانديو يشل كييري . }
\end{aligned}
$$

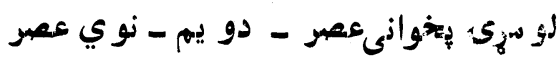

ديخو انى عصبو تار يخخى دو ره بإهدرو برخو و يشل كميون

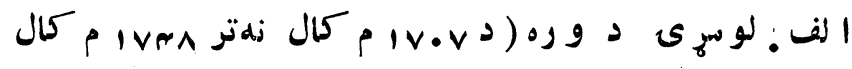

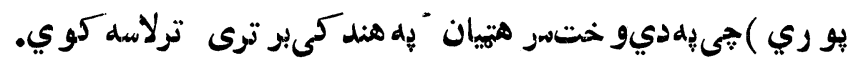

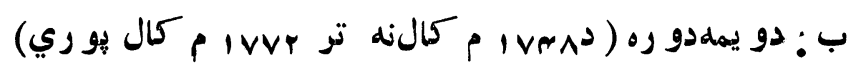
جىددو ي تها كنى بيز سختخو نه

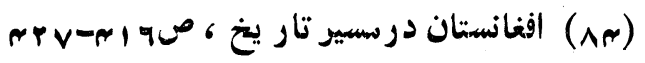

$$
\begin{aligned}
& \text { - vru }
\end{aligned}
$$




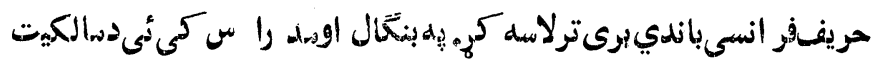
حق يبأسو نده ا ور ياستو نهيى تشكيل

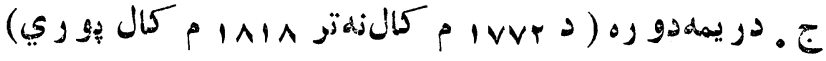

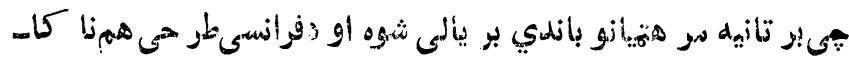

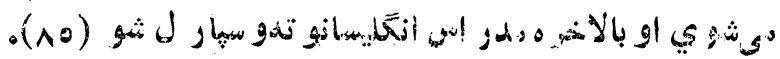

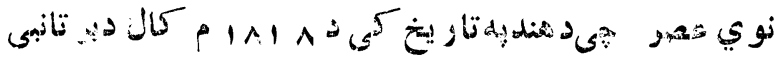

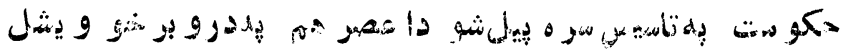

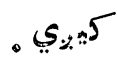

الف : لومئى

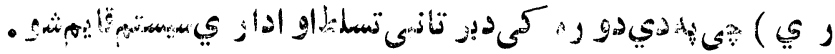

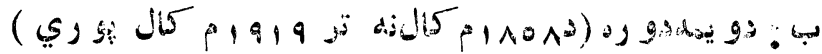

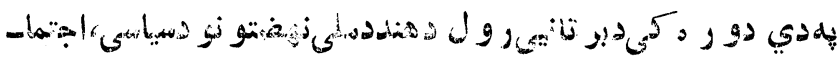

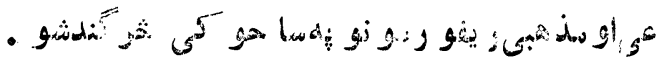
تح:

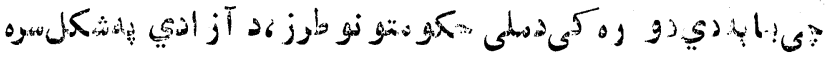
(19)

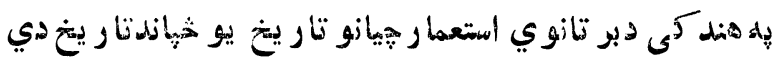

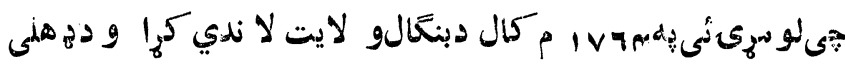

Macmillan, A short History of the Indian people, ; $\mathbf{c}$ ) Calcotta, 1969, P. 245.

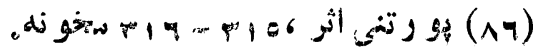




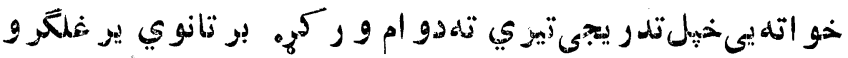

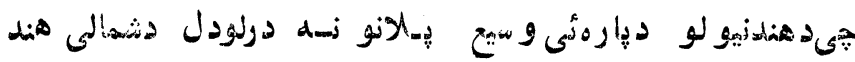

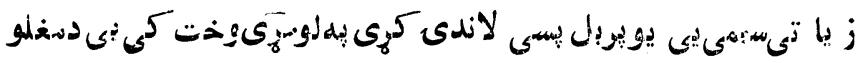

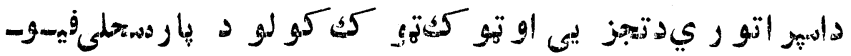

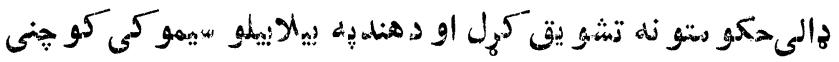

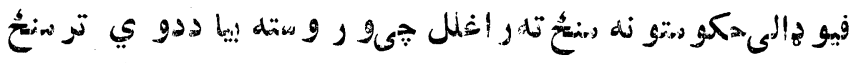

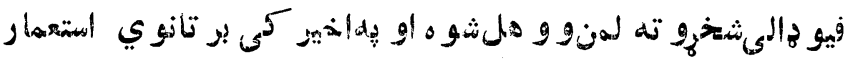

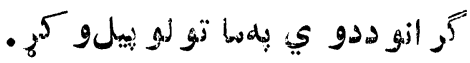

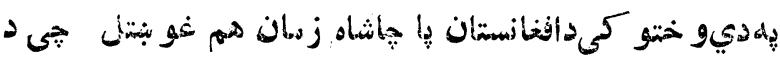

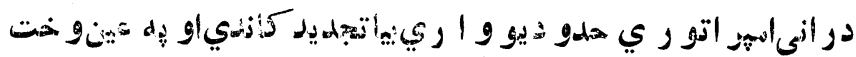

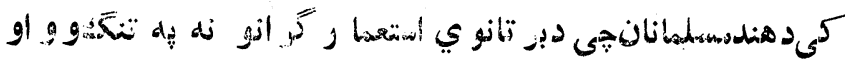

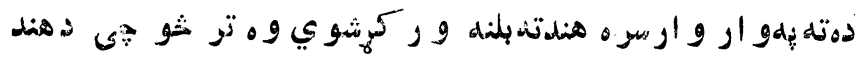

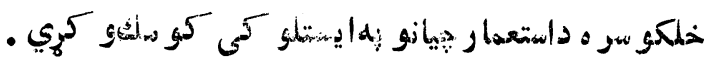

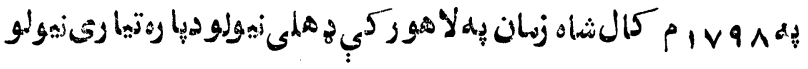

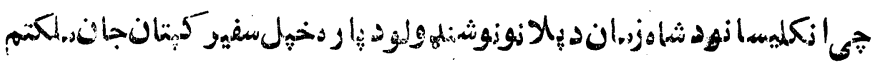

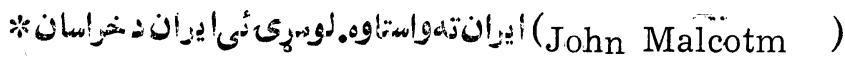

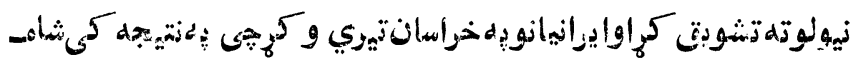

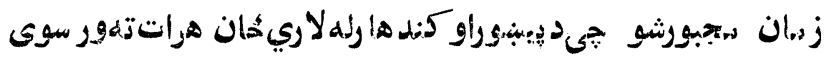

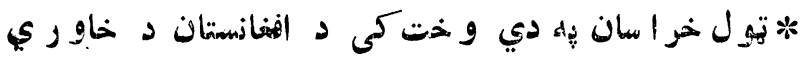

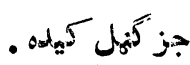




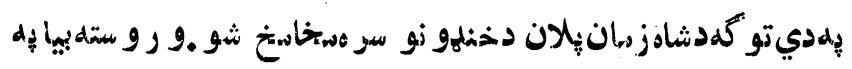

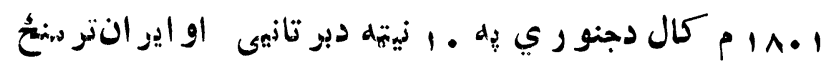
ترو ن لاسليكشو جهى بِهترون كى

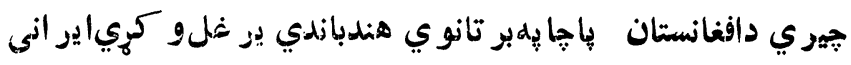

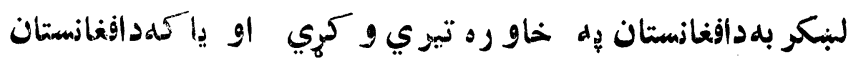

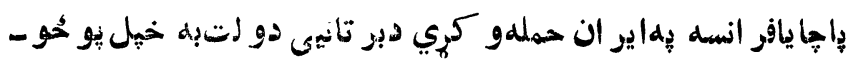

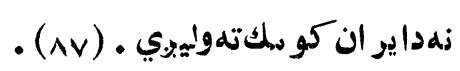

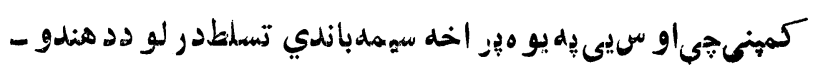

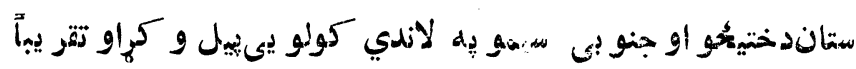

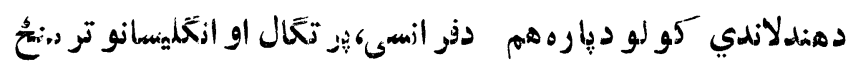

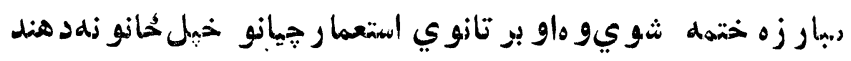

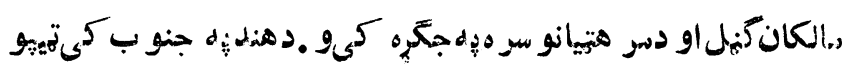

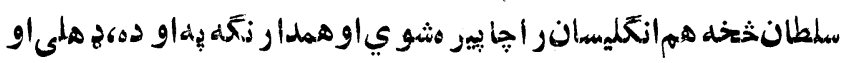

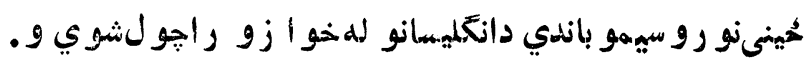

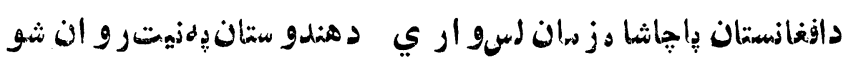

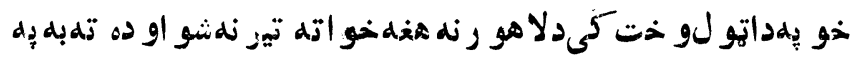

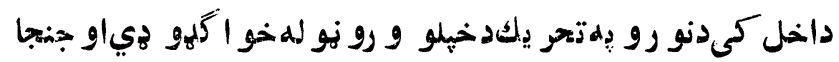

$$
\text { لو لو جيديدا كيدل . }
$$

(AV)

$$
\text { جلمدو م } 6 \text { س • } 1 \text { ميخ }
$$

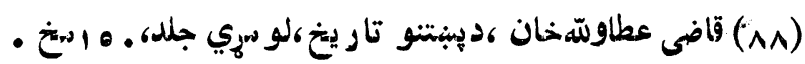


مند ه در انيانو د ادبي اتو ر بي بيلو خت كى د افغانستانيو آباد

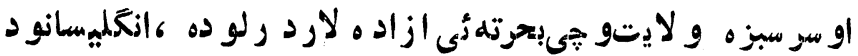

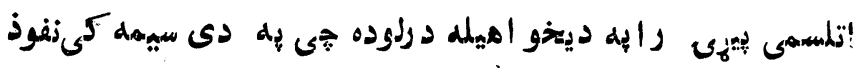

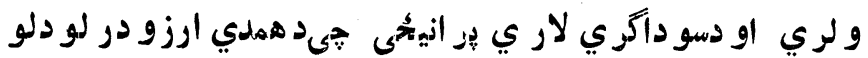

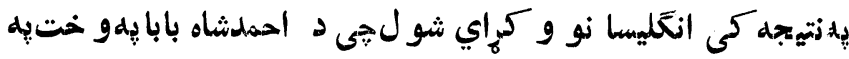

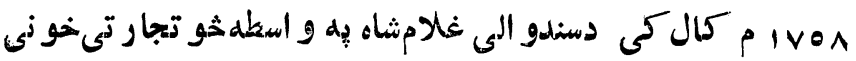

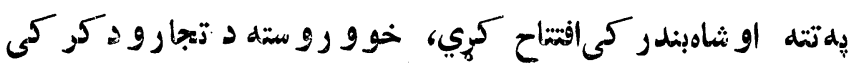

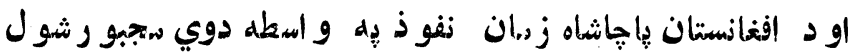

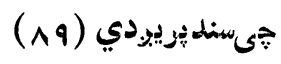

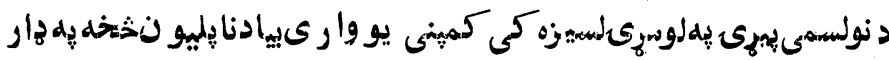

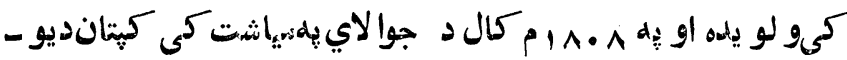
يلدستو ن- Davied Seton- دسنهدسو كز حيدر آبادتهو ليمبولشو

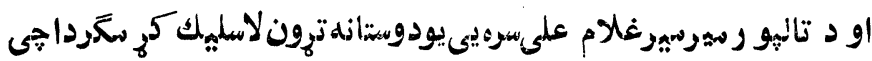

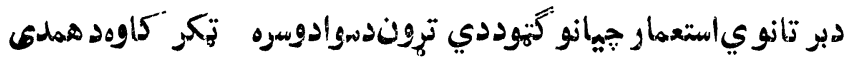

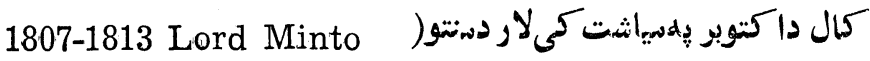
وكتيتاند يو يد ستو ندانهو ر يتنغوه ه

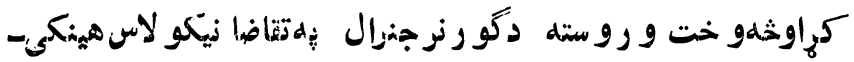

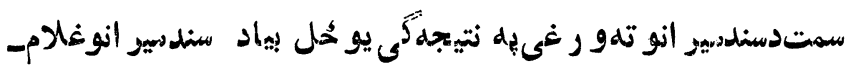

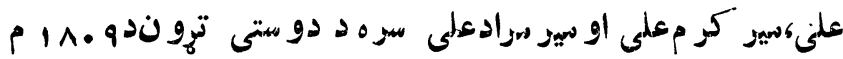

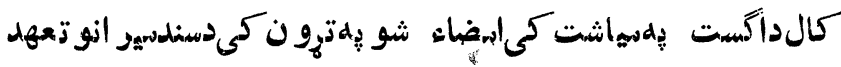

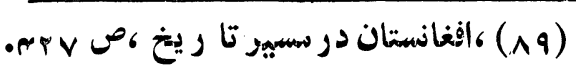




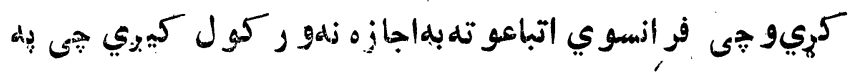

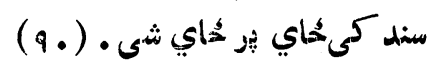

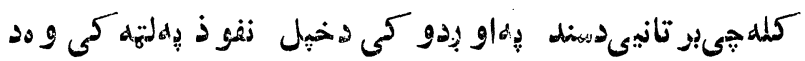

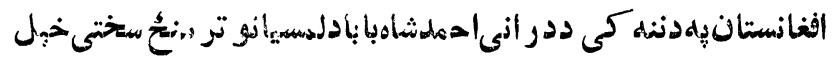

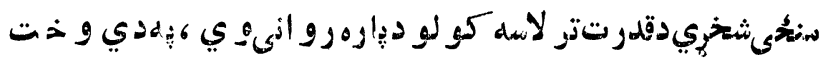

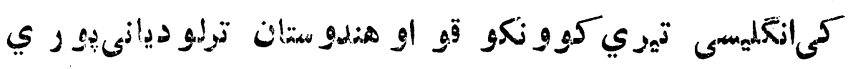

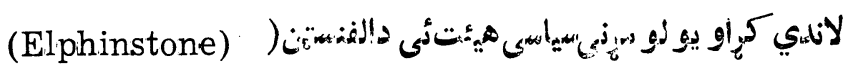

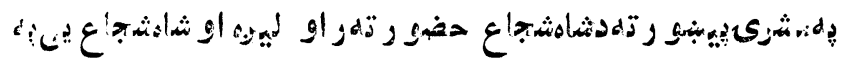

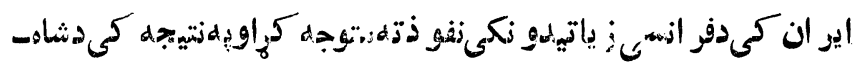

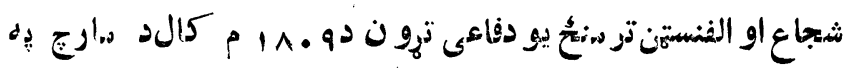

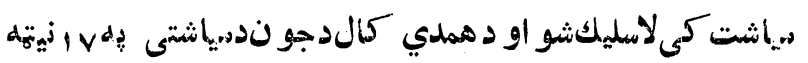

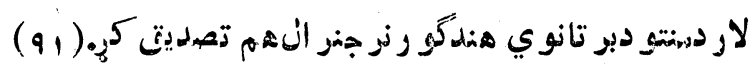

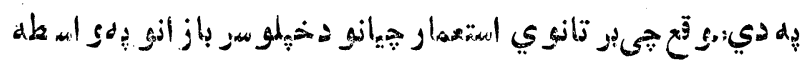

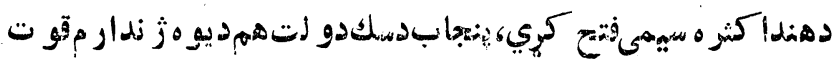

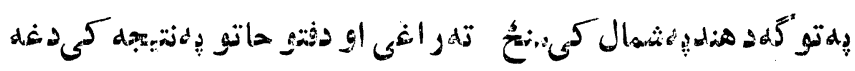

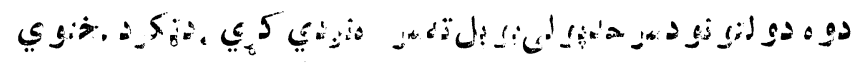

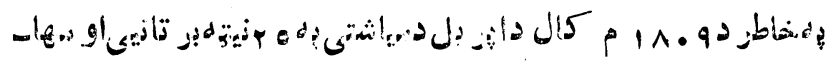

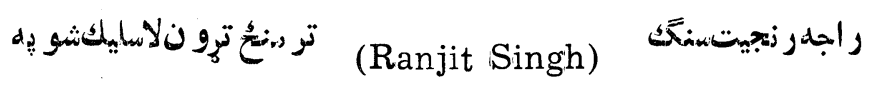

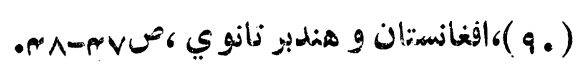

• 


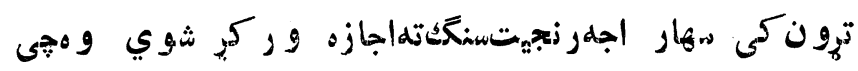

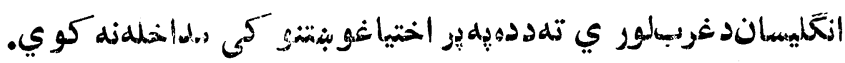

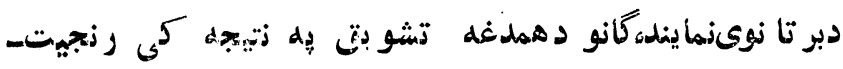

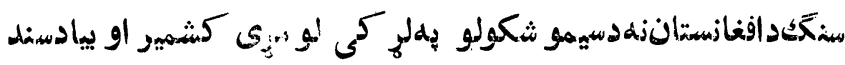

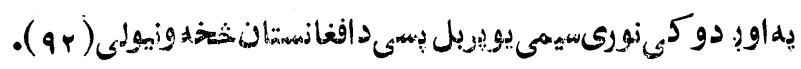
年

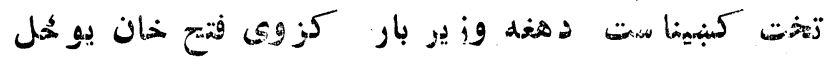

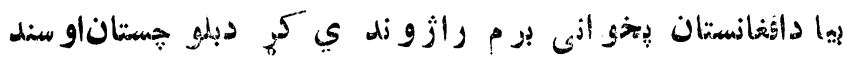

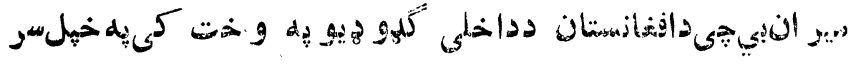

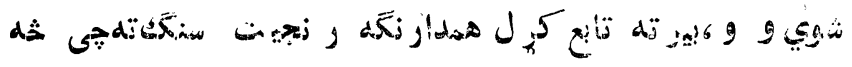

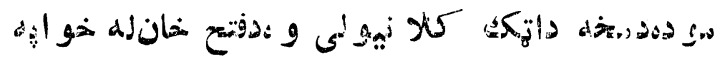

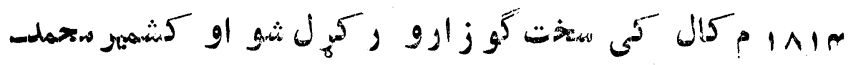

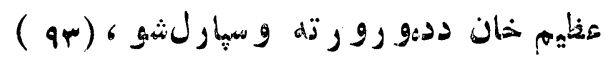

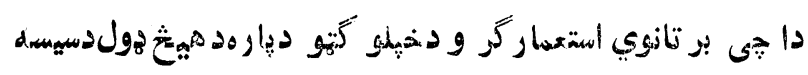

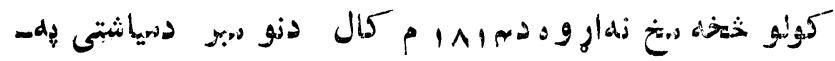

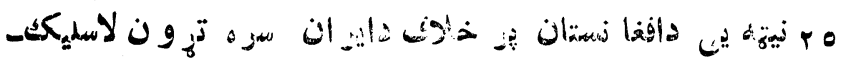

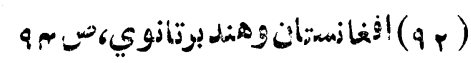

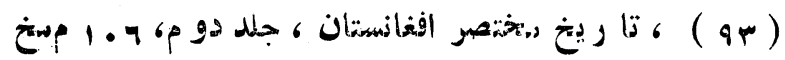




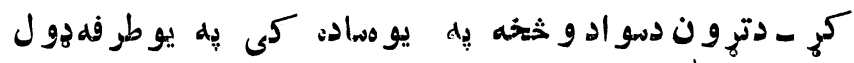

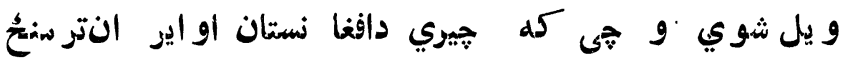

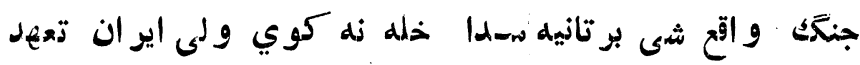

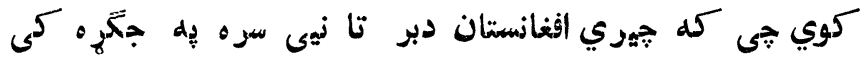

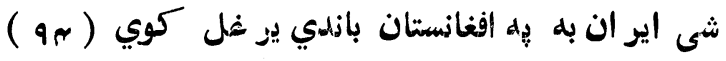

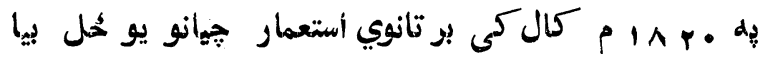

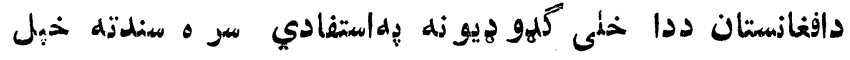

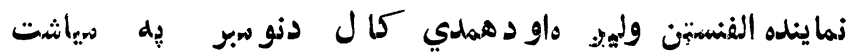

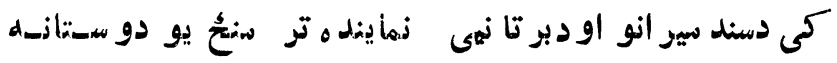

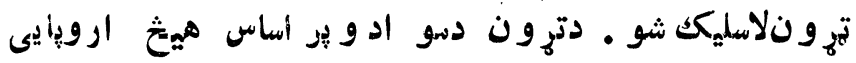

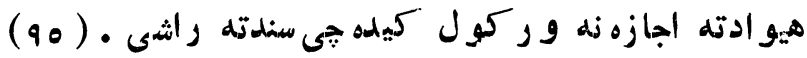

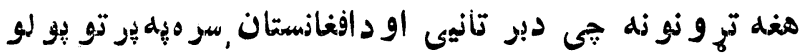

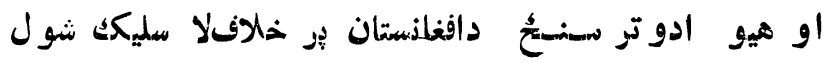

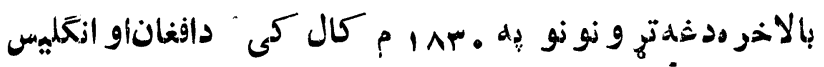

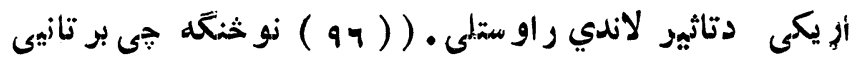
اخجل سو قنف هيه ايوانكى له لاسه ور كري و وكدوي خهبل

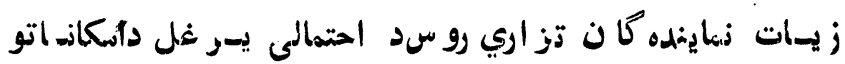

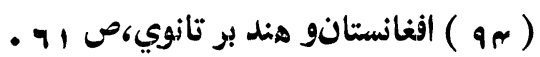

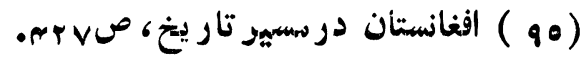

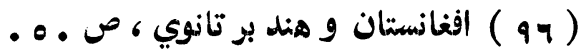




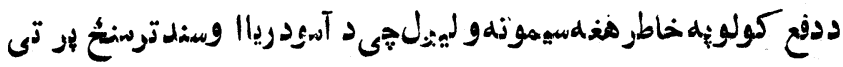

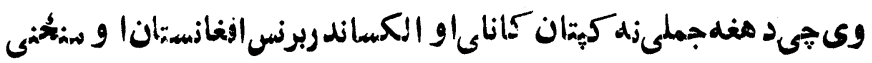

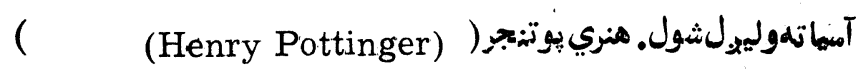

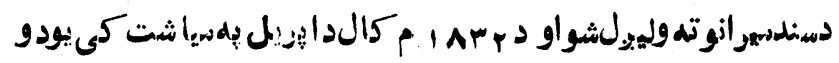

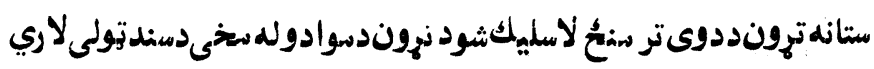

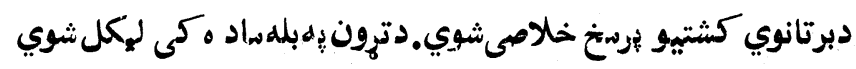

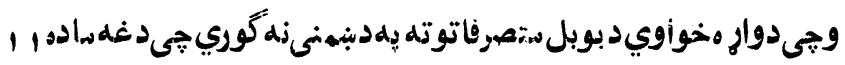

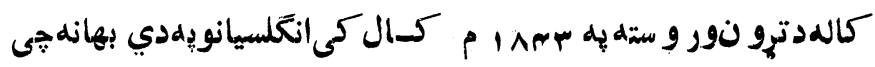

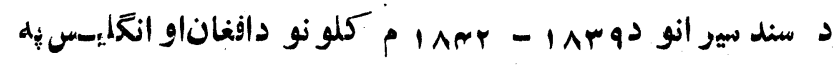

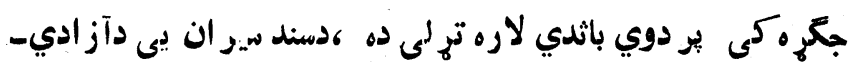

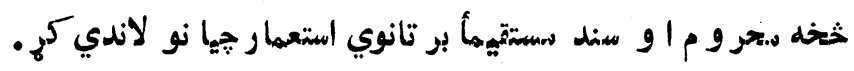
( qv )

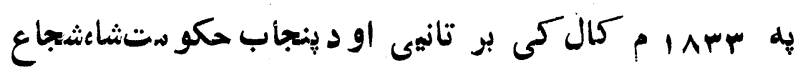

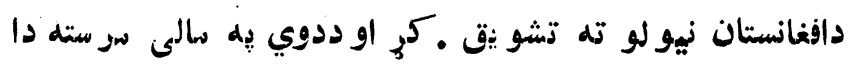

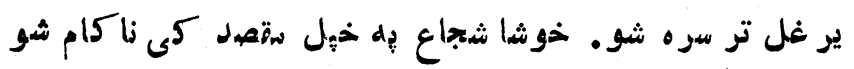
او د تشو يق كو ونكو هيلى هم د خاو رو سوه يو محاي شوي - ( १^)

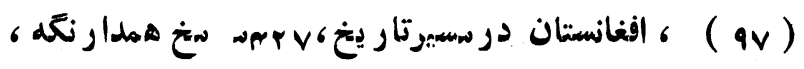

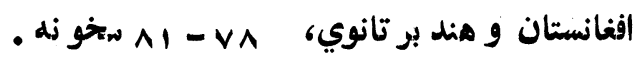

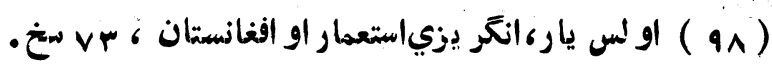




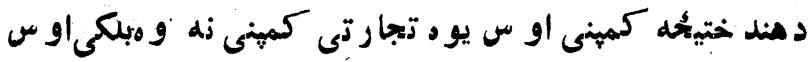

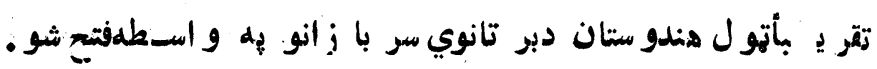

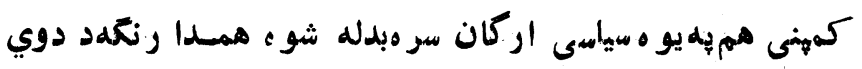

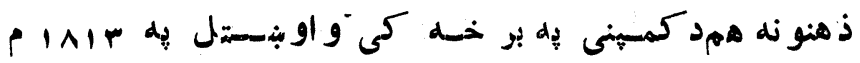

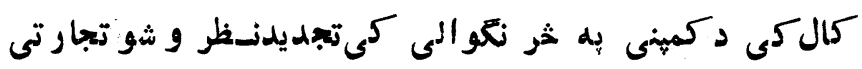

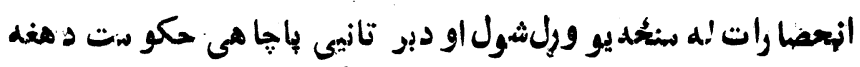
حاي و نسبسو . د سبر ا م كال دقانو ن له ديخى هند و ستان د يوه بر تانوي

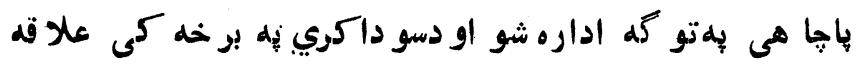

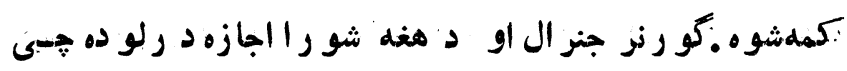

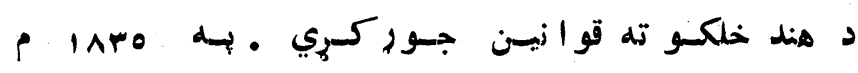

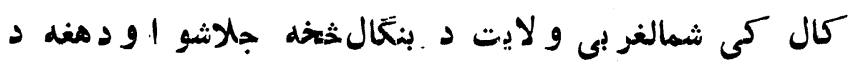
باره نايب المكو سه مقر ر شو. ( 9 و )

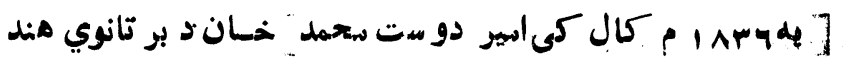

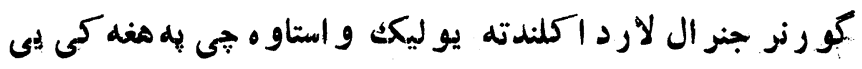

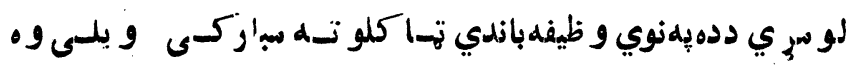

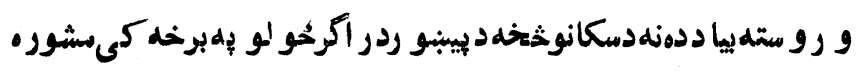

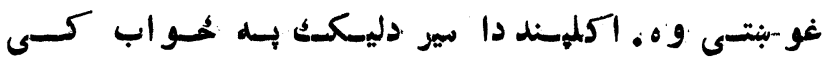

Macmillan, Ashort History of the Indian ( १ १) p. 316. people, 


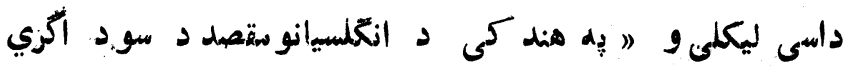

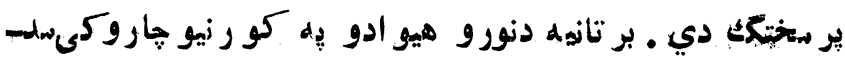

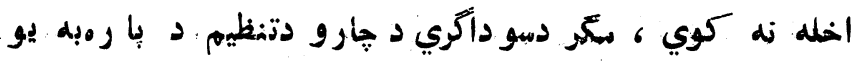

$$
\text { انغكليسى هيئت كابل ته و رشى • ( . ( ) }
$$

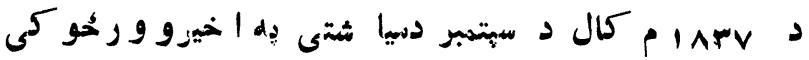

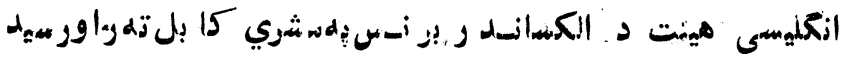

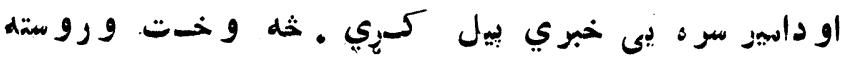

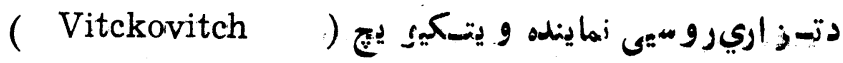
كسابسل تهله راغسى .وي-تكسيو يستع دكسا بهل

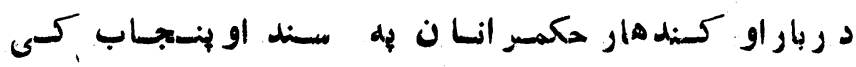

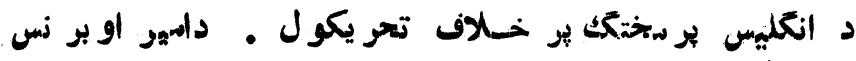

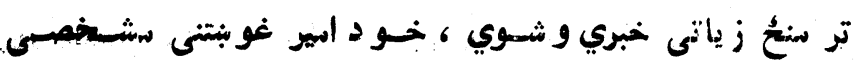

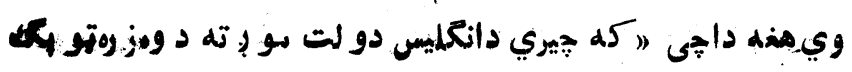

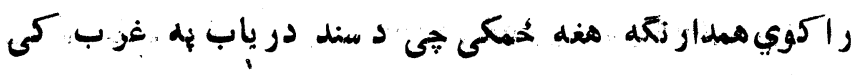

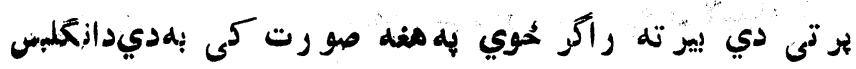

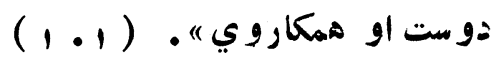

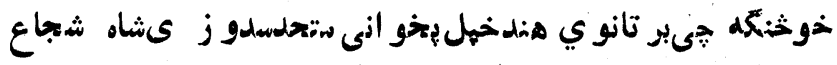

Gregorain, the Emergence ( $\ldots)$

of madern Afghanistan, P. 67

] 


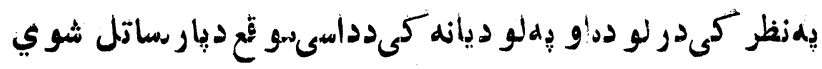

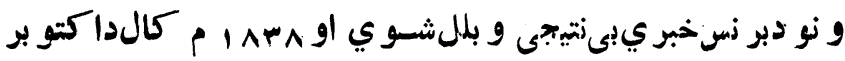

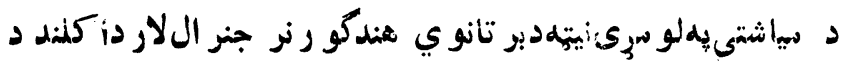

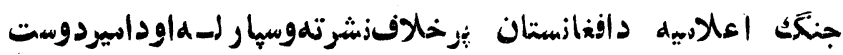

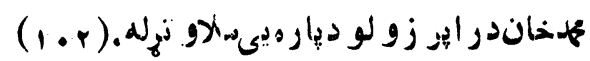

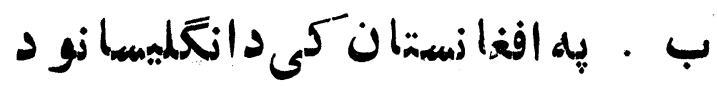

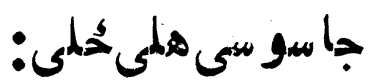

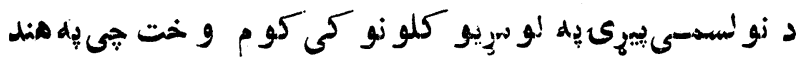

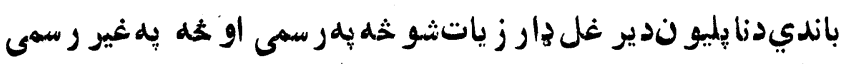

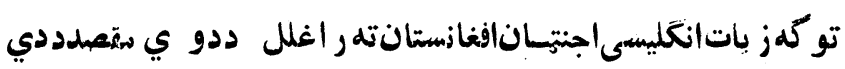

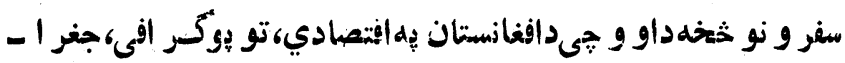

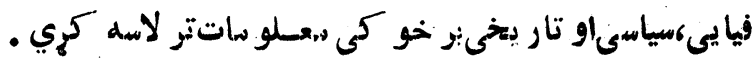

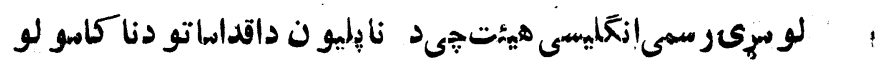

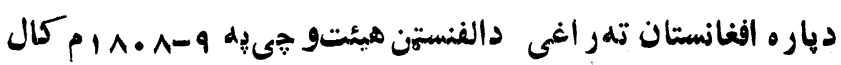

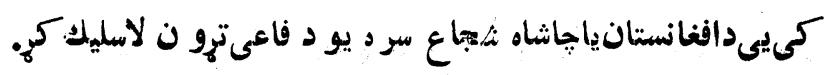
$(1 . r)$

دالفنستن سفر انَّايسانو ته ددي المكانات بر ابر كيرلخو دافغا-

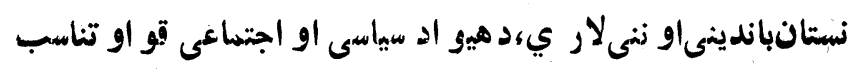

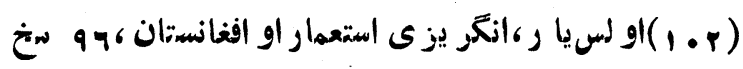
Gregorian, Emegence of Modern $\quad(1 \cdot r)$ Afghanistan, p. 67. 


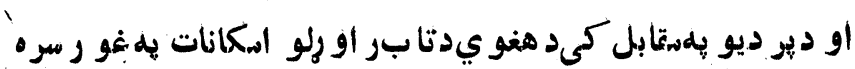

$$
\text { وثيري • (r. • (1) }
$$

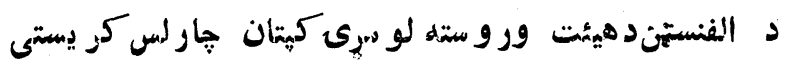

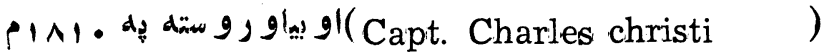

كال كى يو بلازمليسجى هنرى بو تنجر ( ) pottinger )

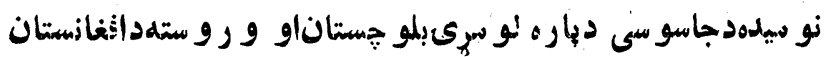

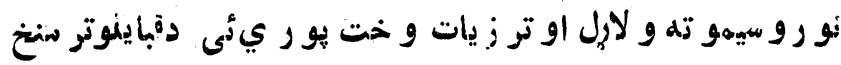

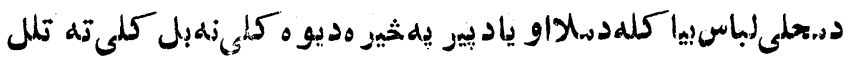

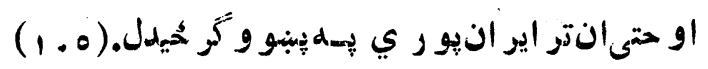

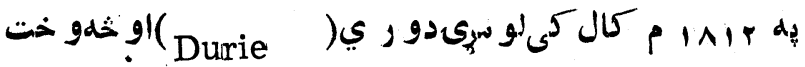

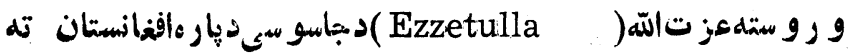

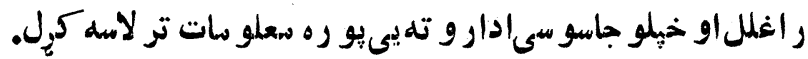

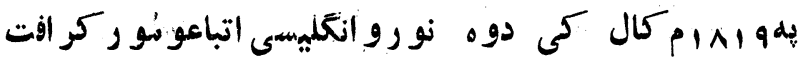

\section{( Trebeck \\ (اوتريبك) (Moor Craft )}

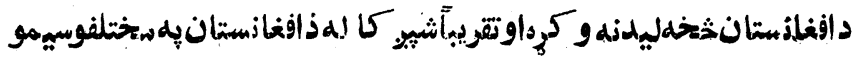

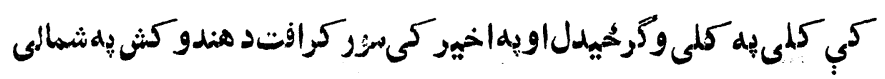

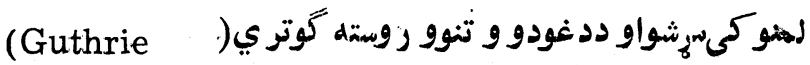

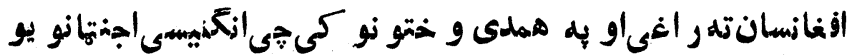

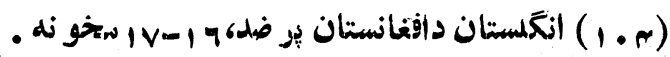

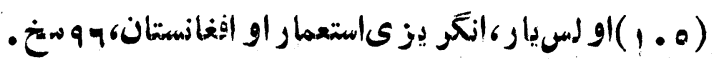




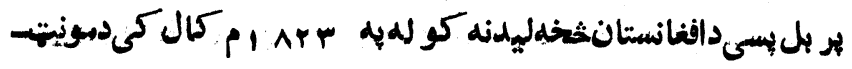

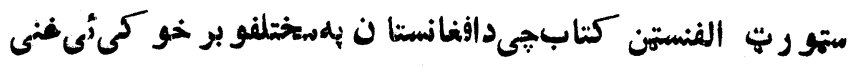

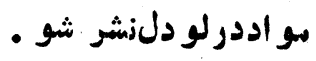

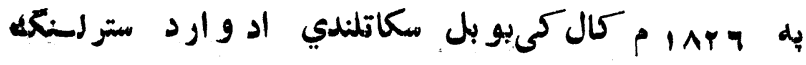
(د) Edward Stirling )

$$
\text { ) }
$$

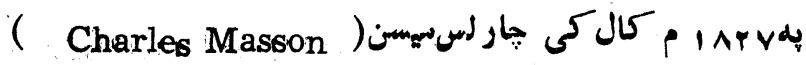

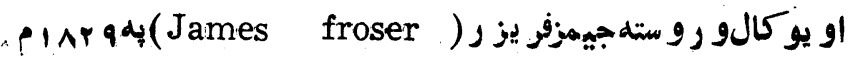

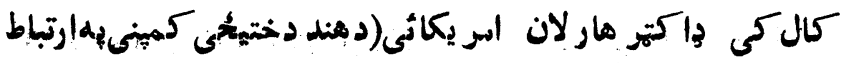

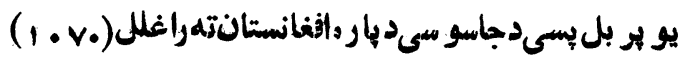

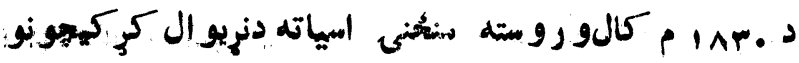

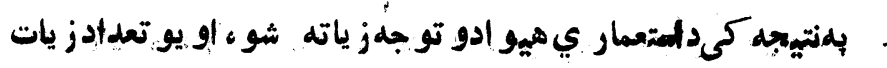

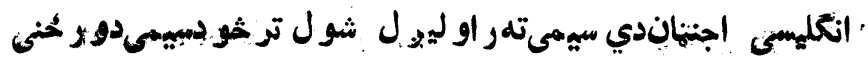

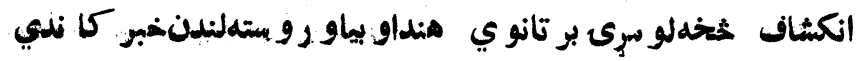

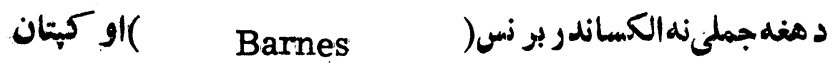
كانولى( Cannally ) افغانستاناو سنيخنى اسياتهمفر

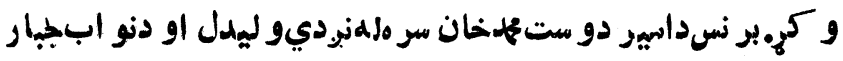

Arthur Swinson, North-West Frontier, p. 35.(1.7)

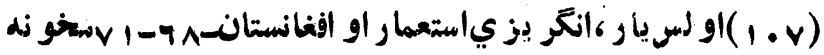




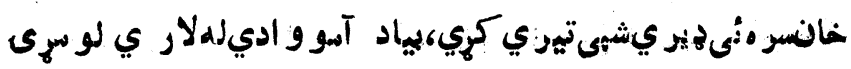

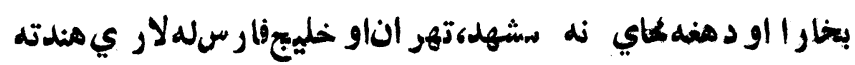

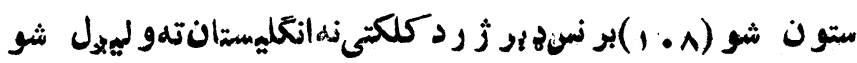

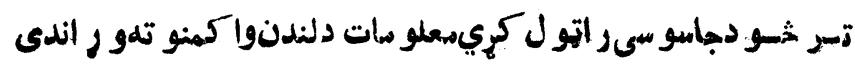

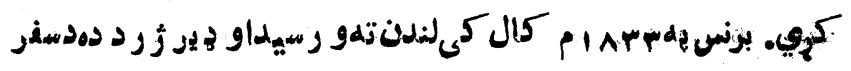

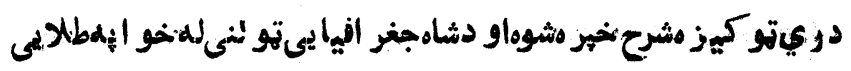

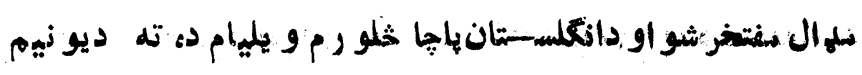

$$
\text { ساعتسجلس افتخار و رو بابنه ـ (q ـ 1 ) }
$$

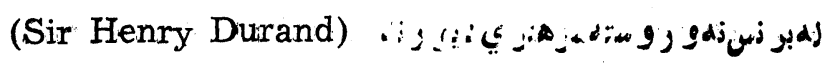

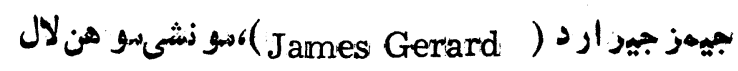
(Sangain (Munshi mohanlal )

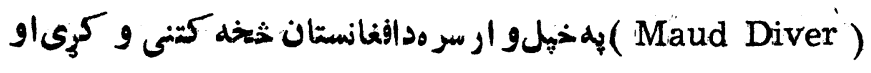

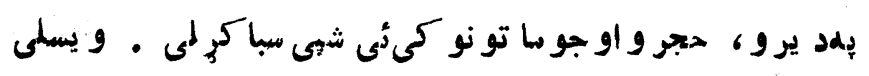
(Wisely )

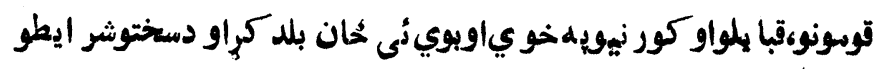

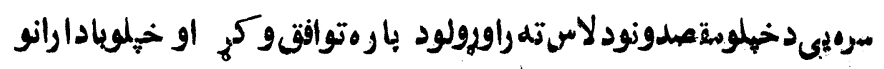

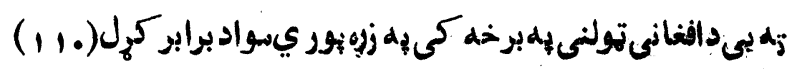

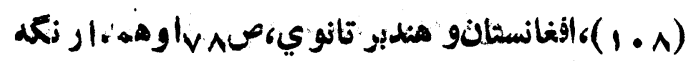

Nonth -West frontier P. 35

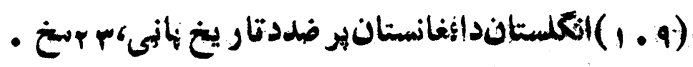

Arthur Swinson, North West frontier, p. 35. (11.) 
苂

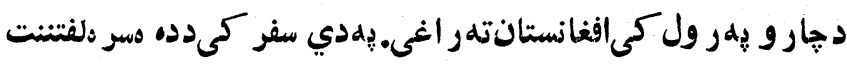

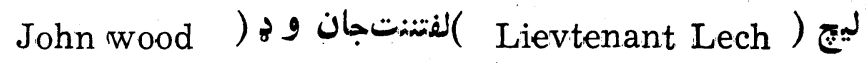

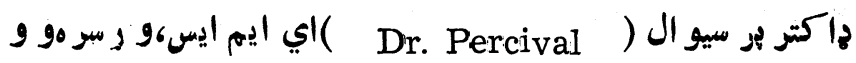

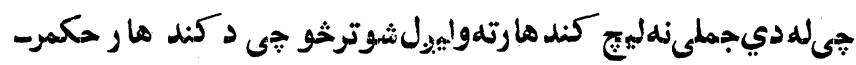

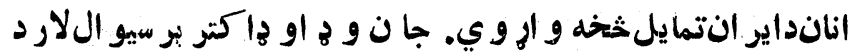

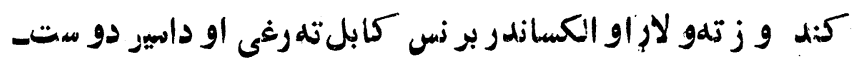

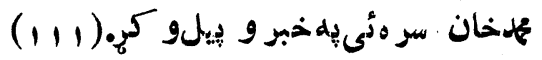

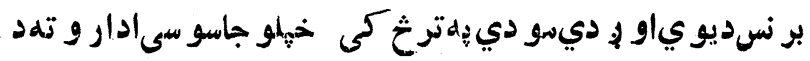

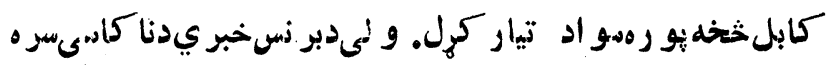

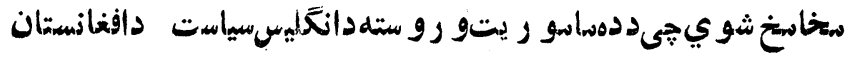

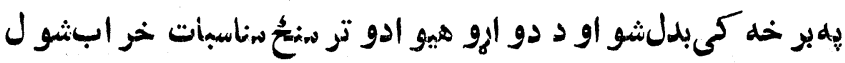

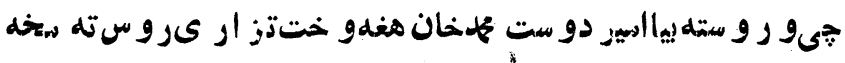

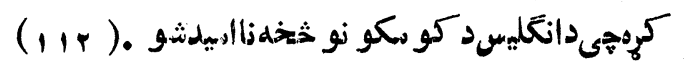

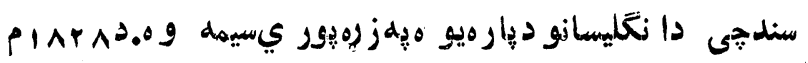

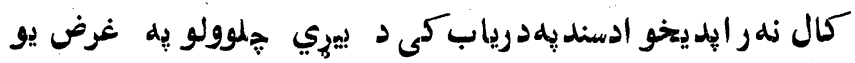

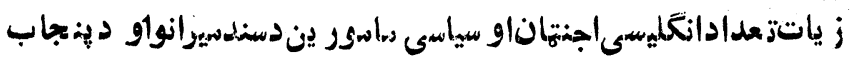

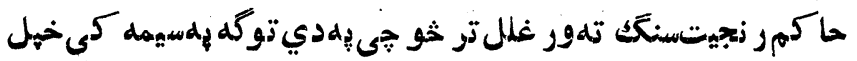
(111)

Gregorian the Emergence of Modrn Afghanistan,

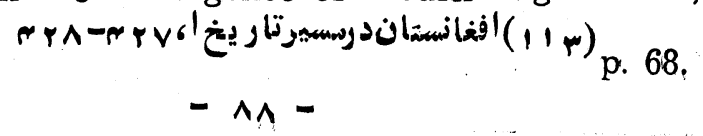




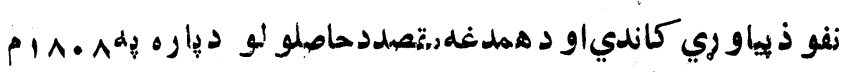

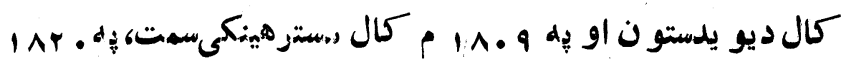

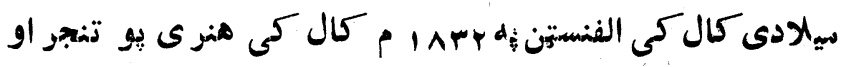

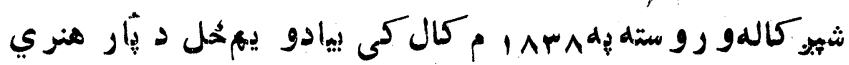

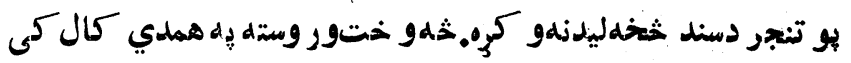

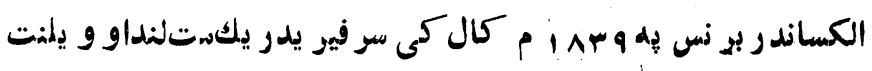
يو بر بل نسسىسندتمسفر و كر.)( 11 ) هو اتدافغانستان دخاوري نه بيليدو نكى جز ديا وبه موقتى

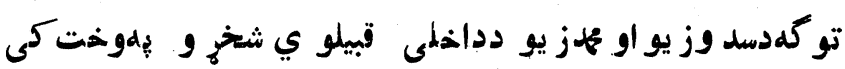

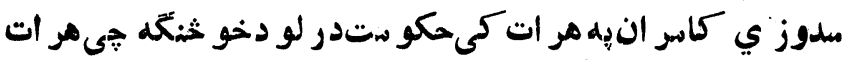

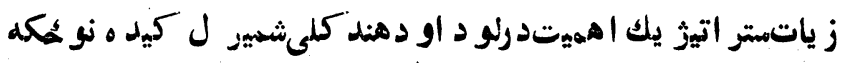

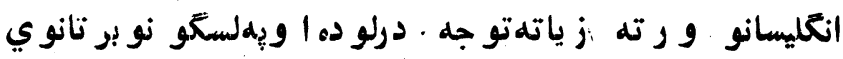
اجنتاناو كرحند و يان للدذغهحاي خخهاير ان تهاو يابرعكسله

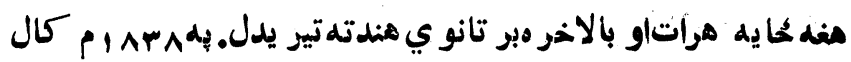

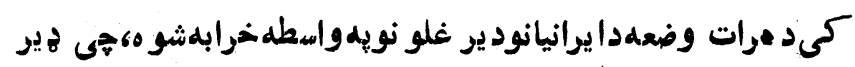
زر بر تانو ينما يندهكان دخيلو كتو ددفاع بِهخاطر خو كفدسياست

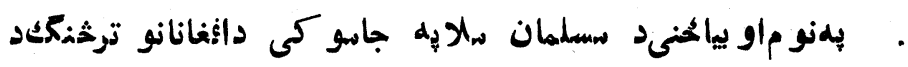

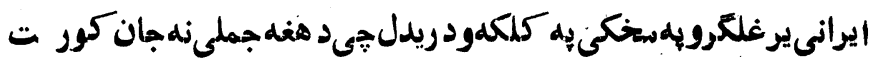

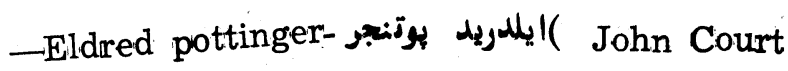

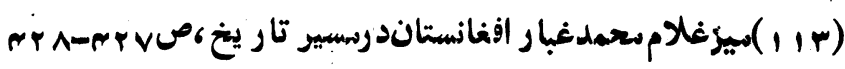

$$
-1^{9-}
$$




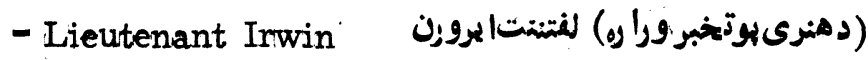

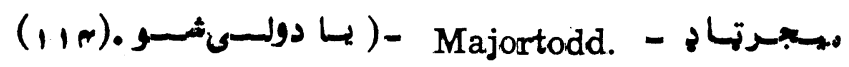

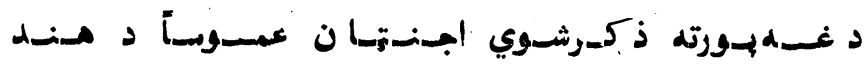

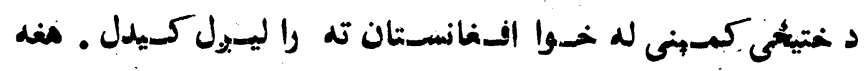

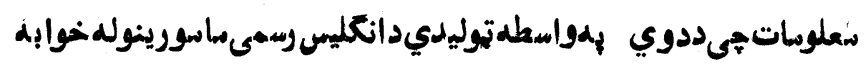

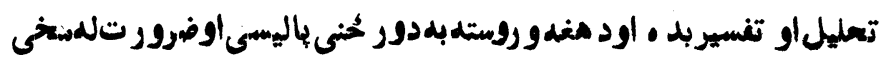

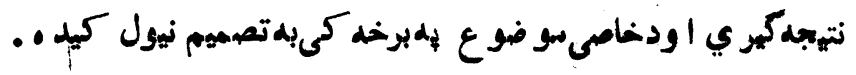

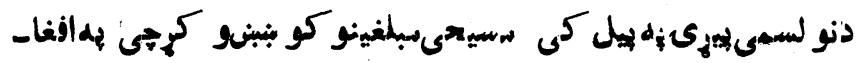

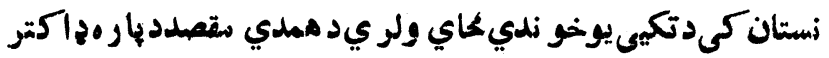
ليدن (Dr. Leyden) دكلكتى بهفو رتو يليم كاليمج كىدانجيل

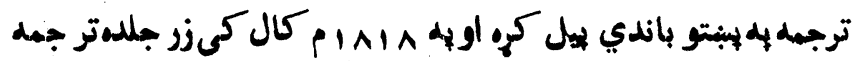

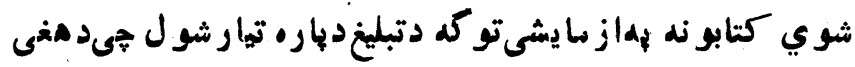
جملىنهخو جلده د مندلهلار ي دلو مانى سو داكر و بهذر يعهافغا-

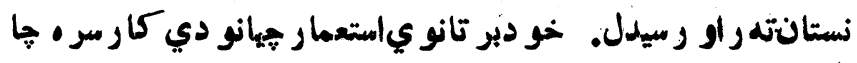

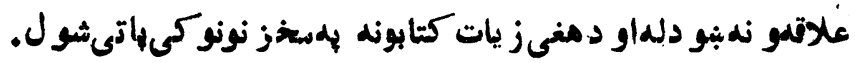

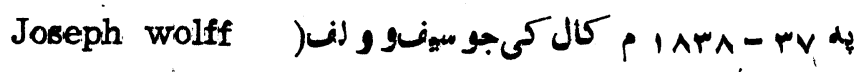

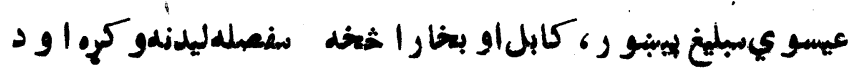

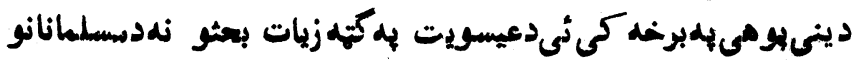

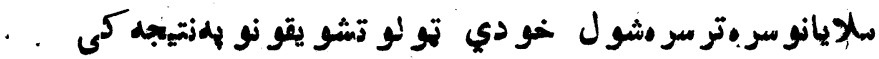

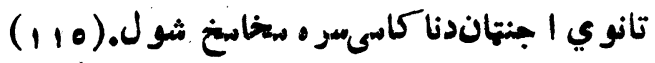

Emengence of Modern Gregorian, the (IIN

Afghanistan, P. 68.

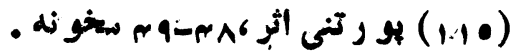

$\therefore \quad-9,-$ 


\section{بنئحم فصل}

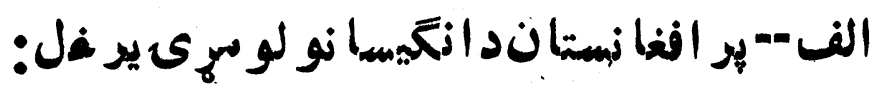

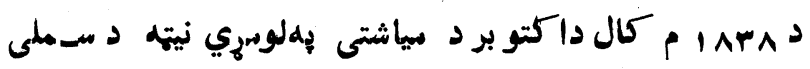

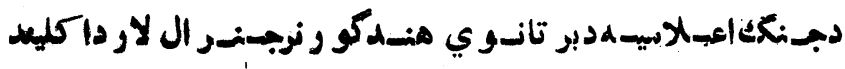

( q (Lard Auckland )

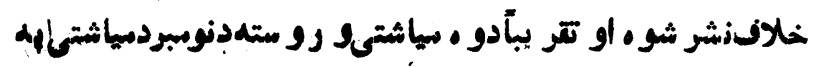

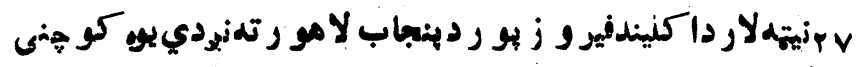

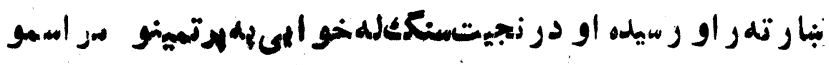

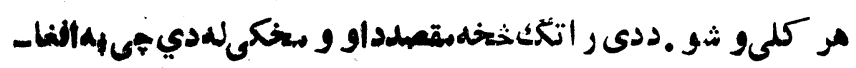

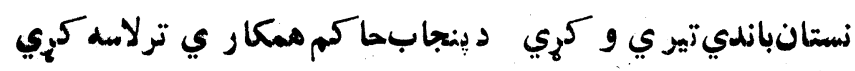

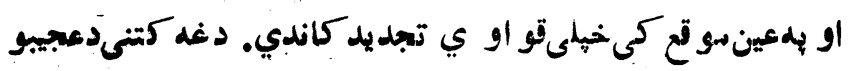

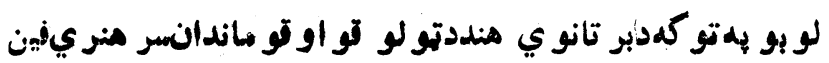

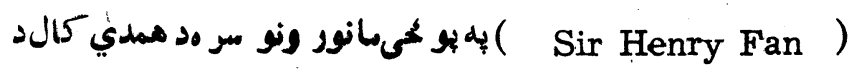

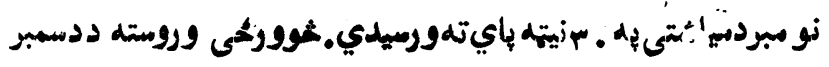

$+\quad-91-$ 


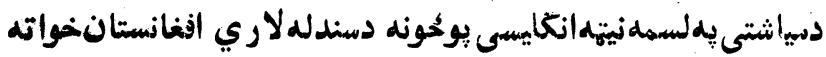

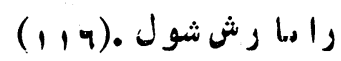

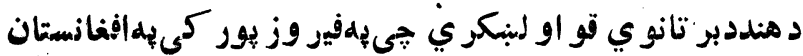

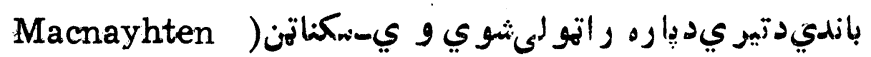

او بر نس( Burnes )يى دهياسىنما يندكانو إه توكة تاكل شوي

$$
\text { و و تر خو د سهو فــياتو ر هبر ي بــهنغاروو اخلى. }
$$

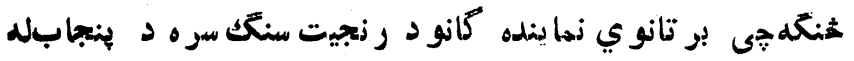

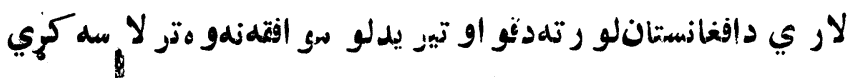

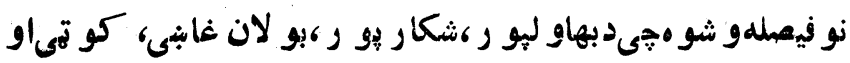
جمن لهلار ي لوسئى كند هار او بياو رو سته كابل دافغانستان

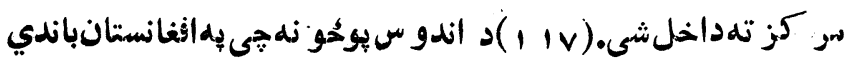
دتجاو ز او . باركز و و رو زود دتكولو او رابرزو نو دياروتيهار

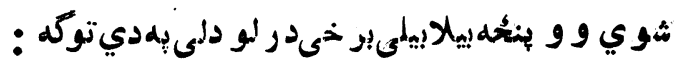
1 - دسنديو حُ جىدبنغال زهر اغلىو او دنيجر جنر السر ولو بهى Major General Sir Willoughbycotton كاتن

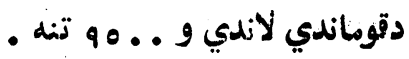

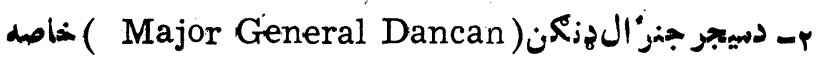

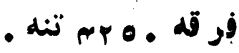

Arthur Swinson, North west frontier, p. 26, 32. (114)

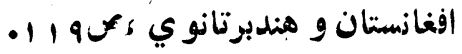
(i,v) $\therefore \quad-9 p-$ 


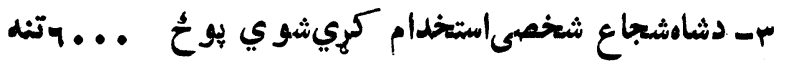

$$
\text { r- دبمبئى يوعُ دلفتنتتجنر ال سو جان كين( }
$$

الو مازدي ("Lieutean General Sir John keen )

$$
\text { . لازدي ... }
$$

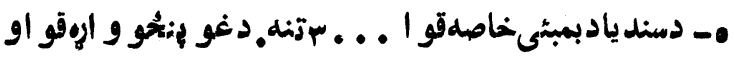

$$
\text { • • }
$$

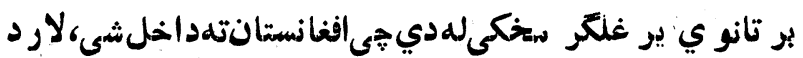

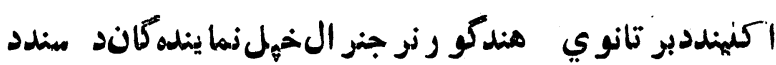

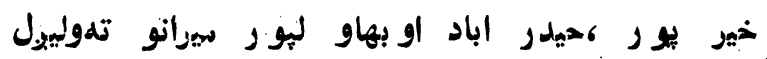

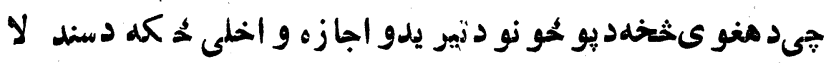

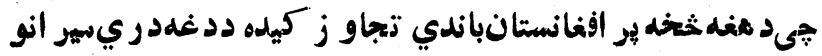

$$
\text { سيمو شخهلتير يده ـ (11) }
$$

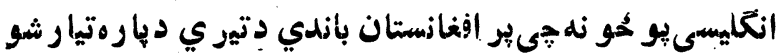

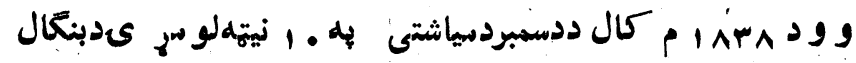

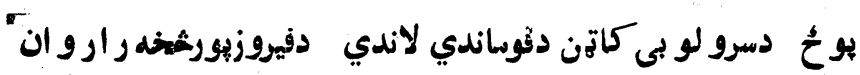

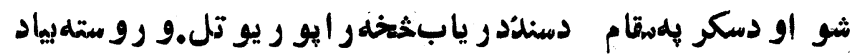

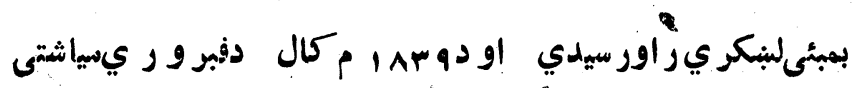

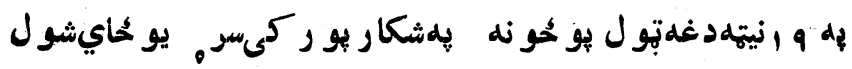

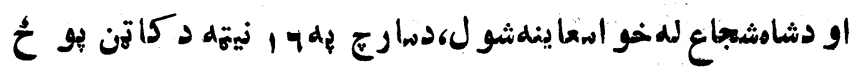

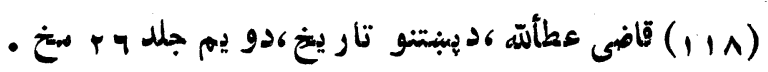


دكو تقلهلارهكىدبو لاندر ي تلر او رسيد او بهلاوه كمد

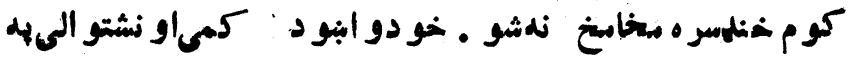

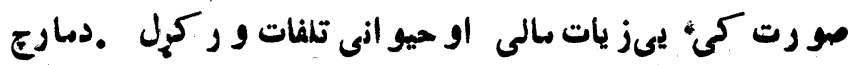

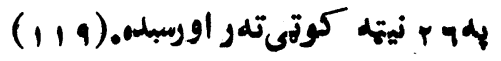

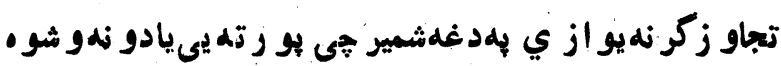

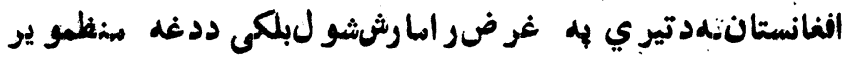
فلكر و جنكيالو تولكيو تر شاكنشمير كار كنان، كو هنىسو داكر

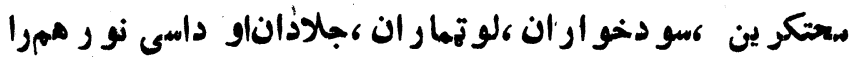

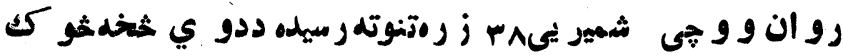

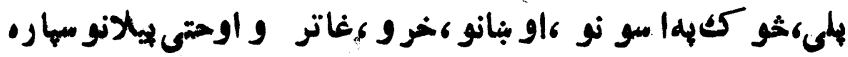

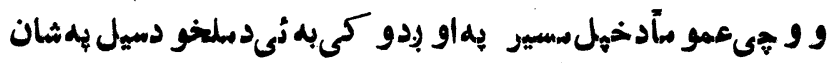

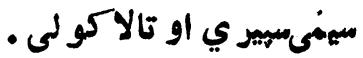
بر تانوي سياسى او زظامى ر مبر انو سو م ددي تهى دالفانستان

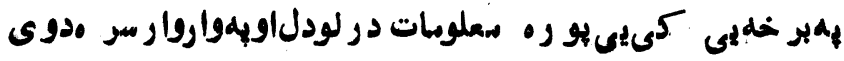

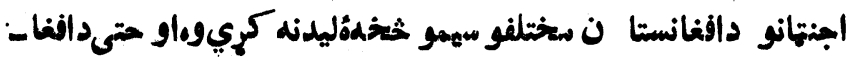

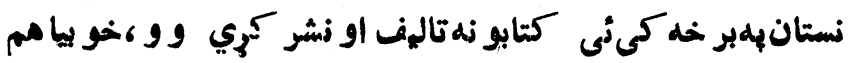

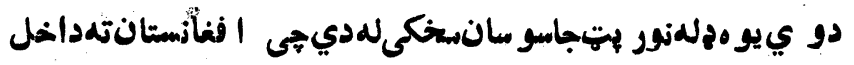

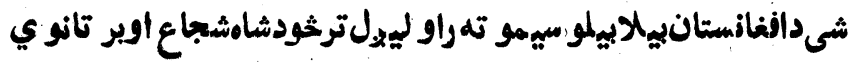

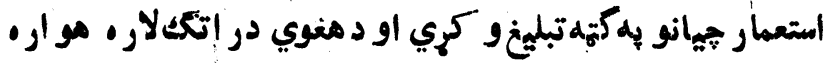

Arthur Swinson, North West frontier, P. 46-47. 
كوي. جهى هغو ي جملى زمهستر لار دتخار او بلخ ته، لفتنتتسيكسن

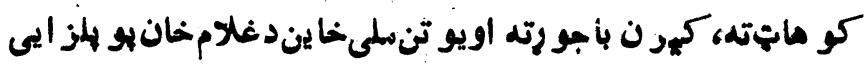

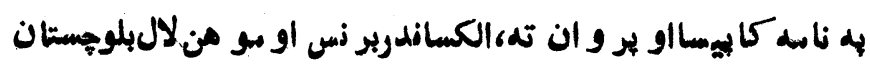

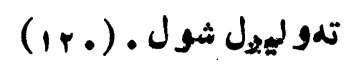

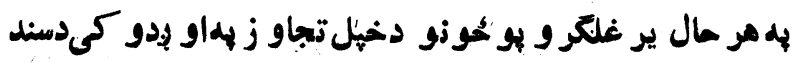

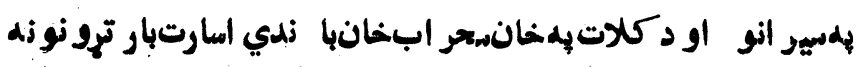

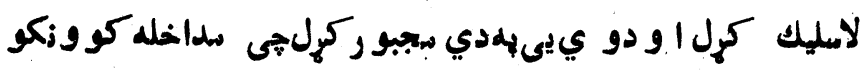

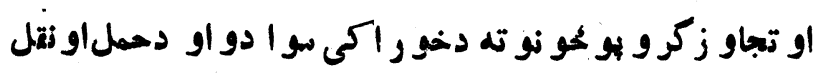

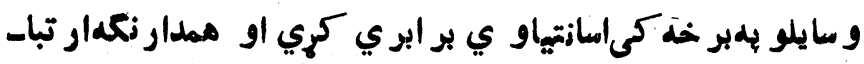

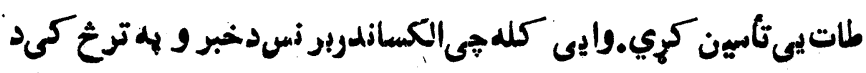

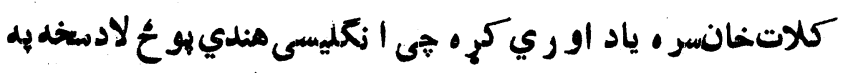

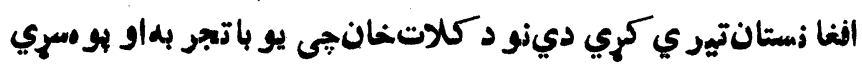

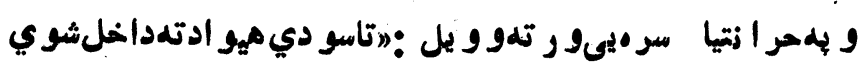

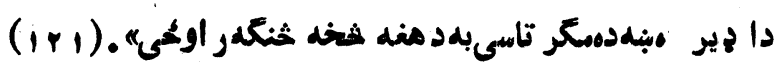

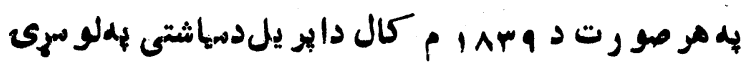

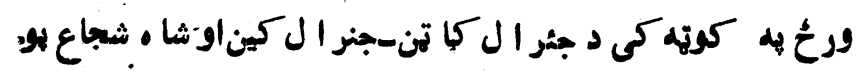

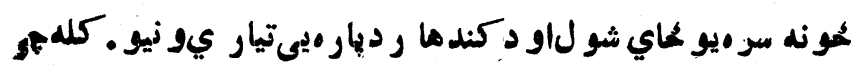

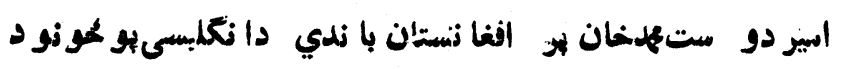

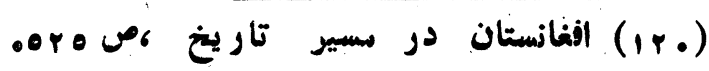

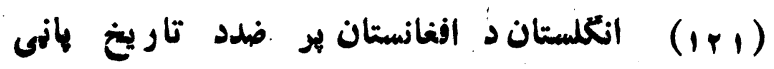
- غ八016 


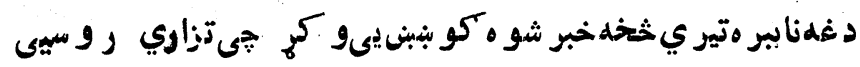

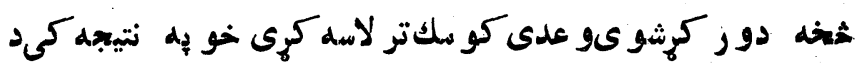
ده هغوكو م محأى و نه نيو ، او يهعينو خت كندلخان مهمداير ان

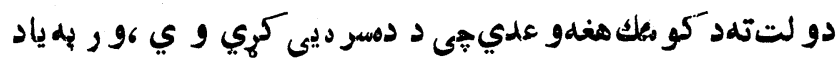

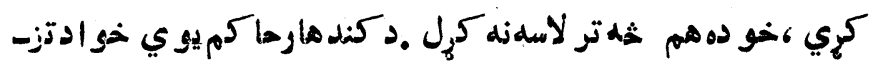
اري ر و سيىاو اير اندموستى دناا ديديميهسبباو دبلىخو اددبنهن داجنتانو دتبليغ بهو جهد د بنهن سوه مقابله ناسمكنهو كنهلهاو دفر اهاو

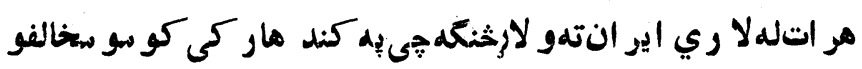
قُو او و و جو دنهدر لو د نو بر تانوي أشغالكوي قو او ي بـلهدي

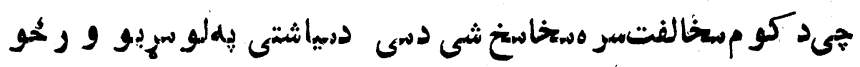

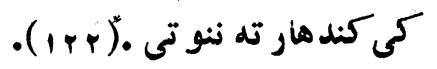

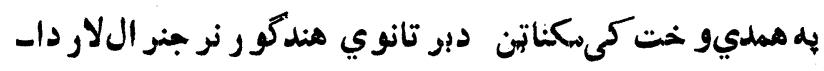
كليندتهاو هغd بيا بِهخيلو ار لندنته دافغانانو لهخو الد شاه شعاع

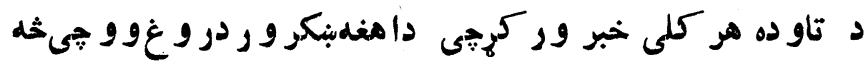

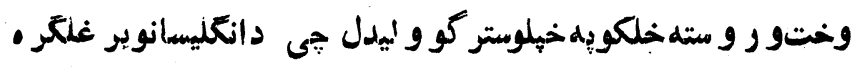

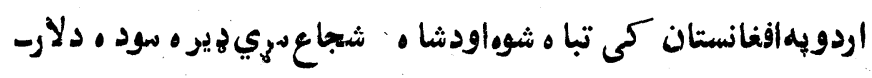

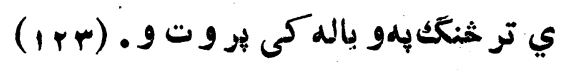

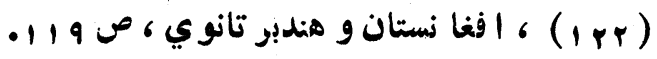

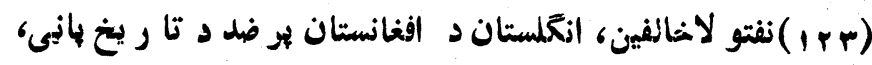

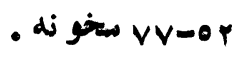




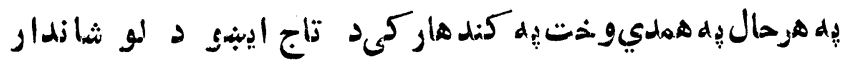

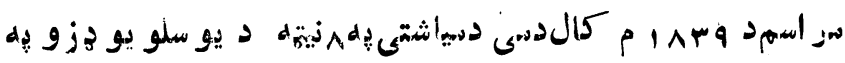

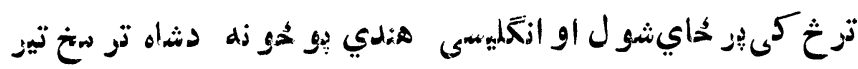

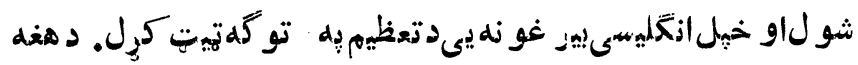

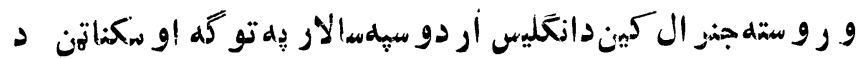

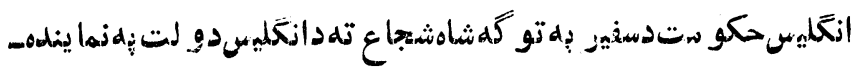

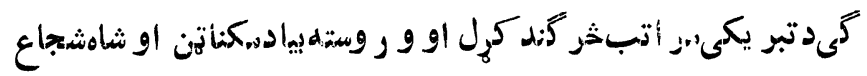

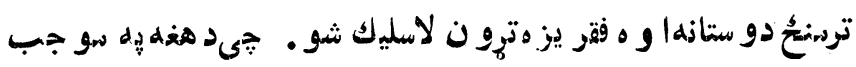

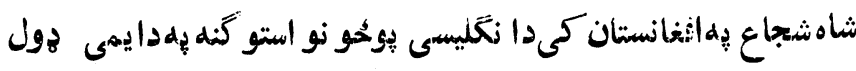

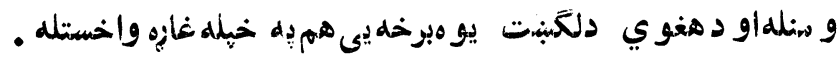

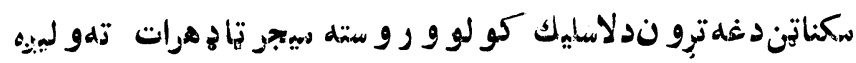

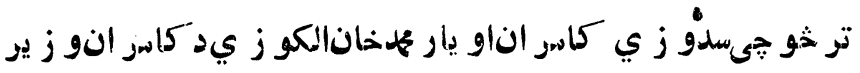

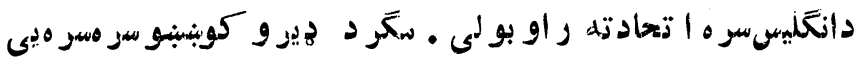

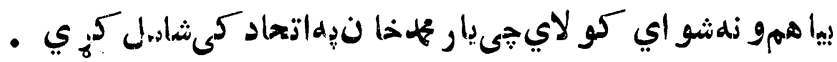

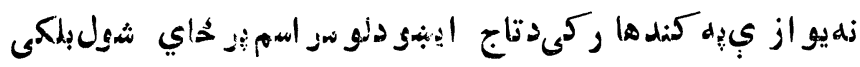

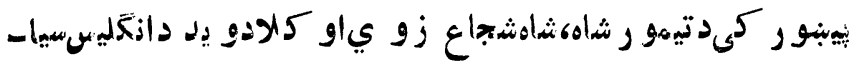

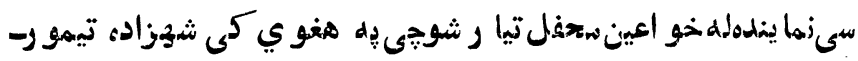

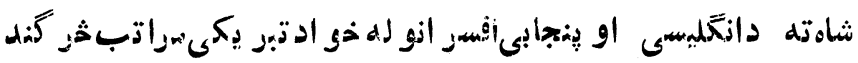

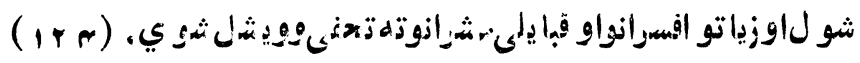

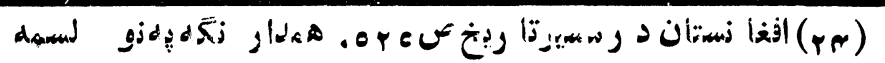

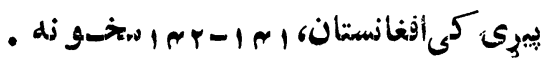


ب .. بر تانوي ير غلكَر انبه كند هار ـ غز نىاو كابل كى:

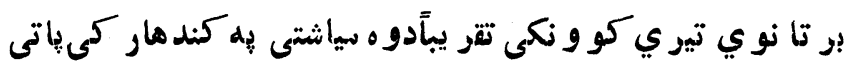

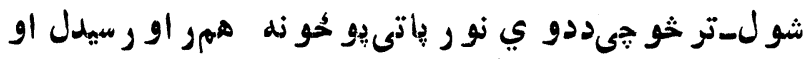

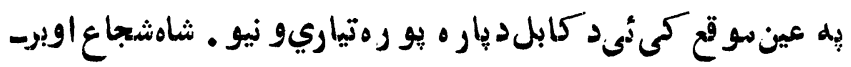

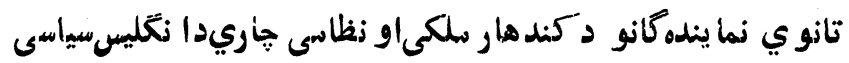

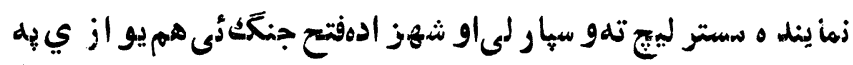

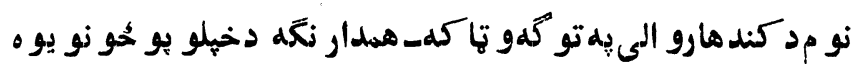

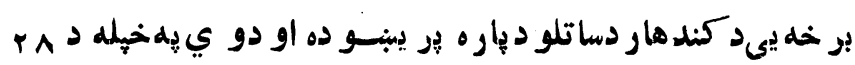

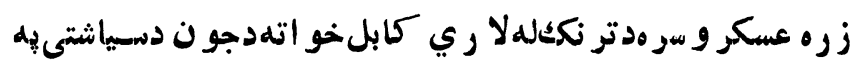

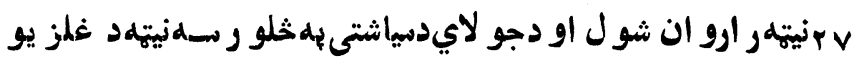

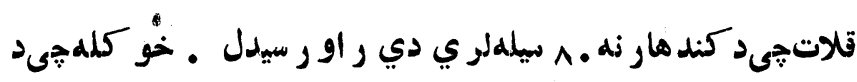

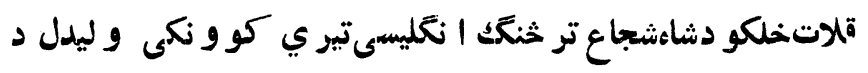

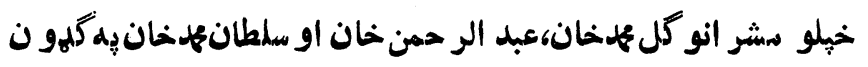

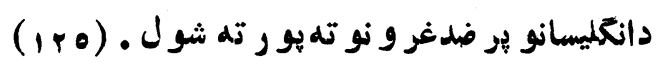

بر تانوي اشغالتخر د قلات تر نيو لوور و سته د غزنى بهلهور رارو ان شول ، خسو إهل لار و كسى د غلز يو ير غلسو نو برد و و ي با با ندي

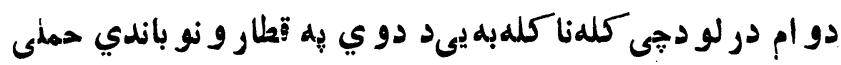

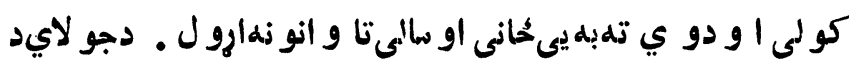

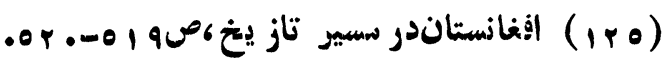




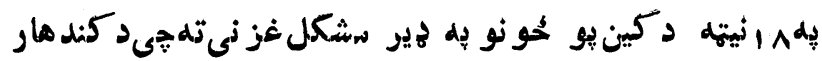

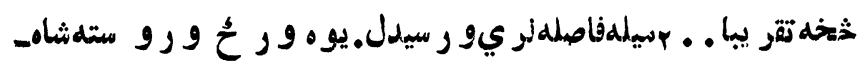

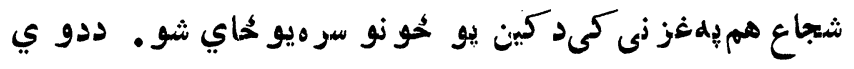

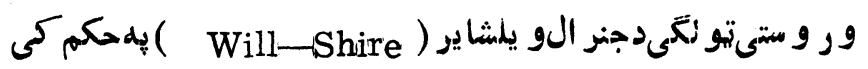

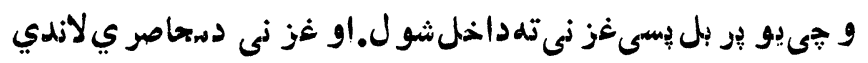

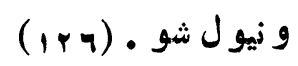

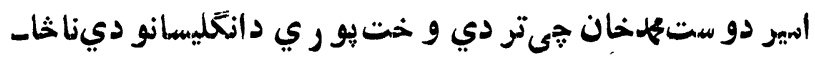

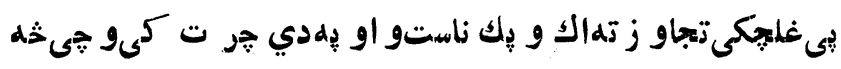

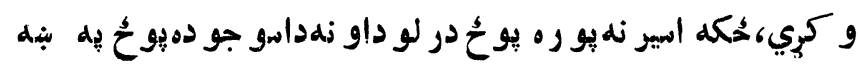

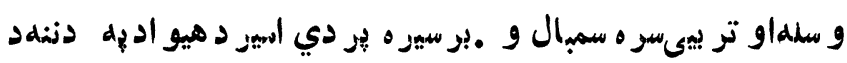

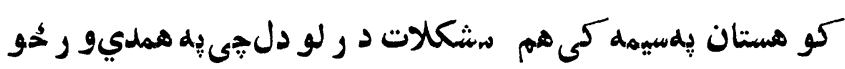
كى شير علىخاندخهيلو عسكر و سر ه هغلسيمى تهدشو ر ثيا نو دنّكو

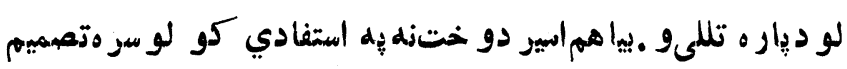

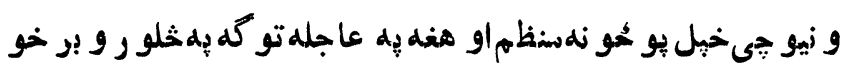

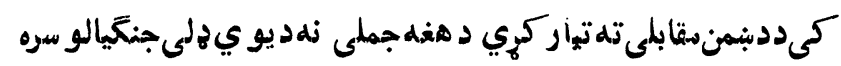
ؤىخيل زو ي أكبر خانختيكو بو لو خيبر د ريت له و ليبرهترخود

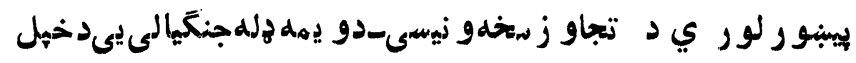
زو ي غلامحيدر خانتر قو ماندي لاندي غنز نى خو اته و استول لهاو

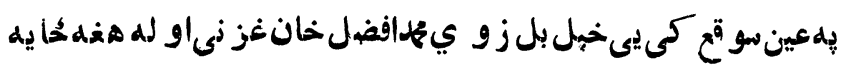

Arthur Swinson, North West Frontier, P. 48-49.(I I 


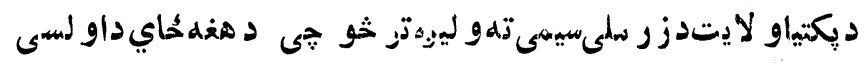

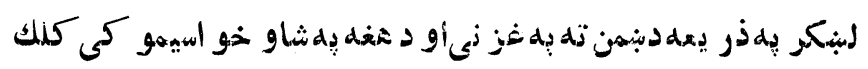

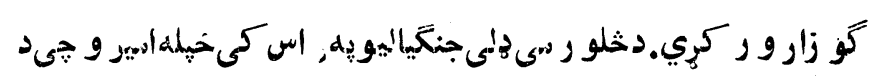

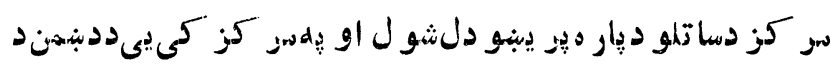

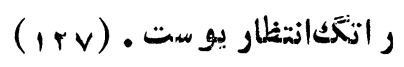

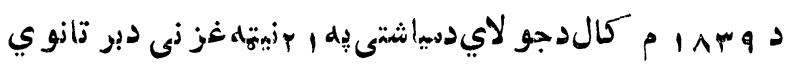

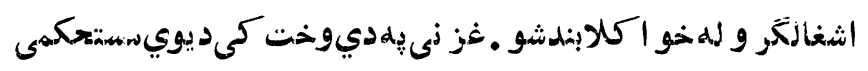

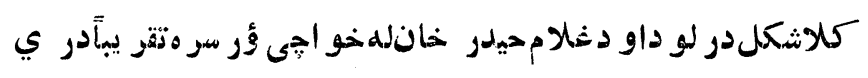

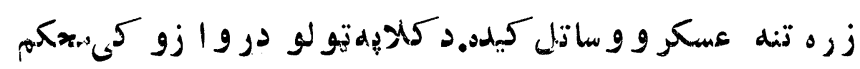

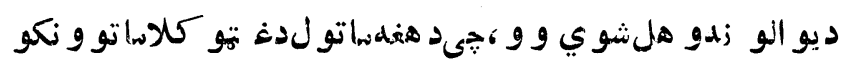
تو بو نو إزو تهاسكان زلهدرلو دده.يو أز ي دبنار كابلى دور و ازهدتكَك

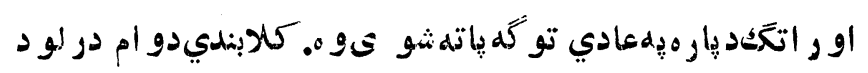

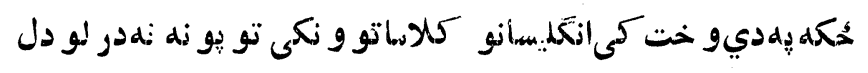

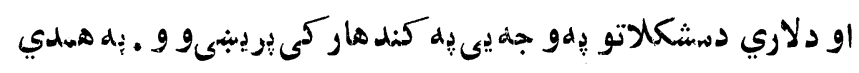

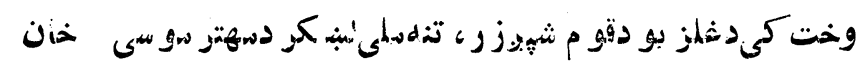

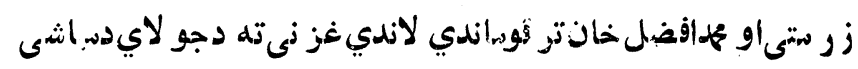

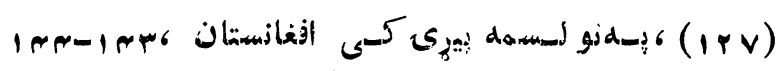

$$
\text { - di } \dot{ } \text {. }
$$

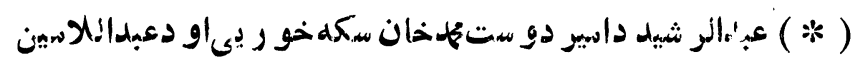
خان زو ي أو دانكَليسانو جيزه خور ر و . 


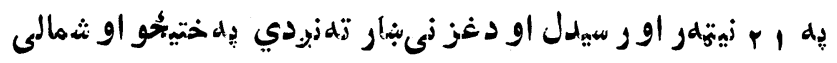

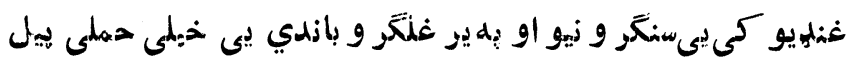
كري

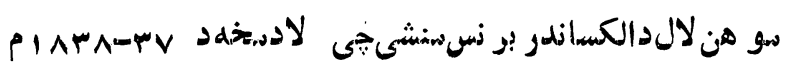

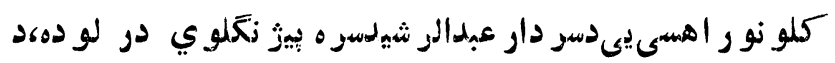

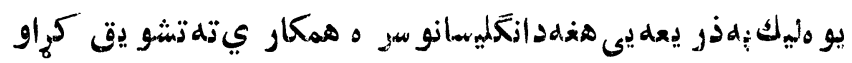

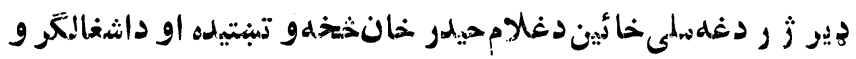

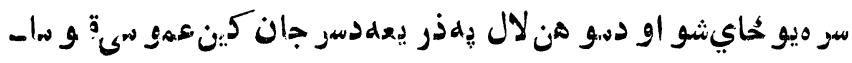

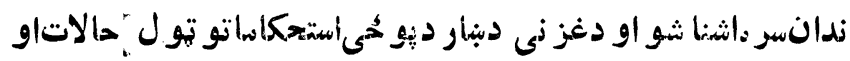

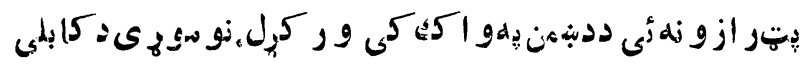

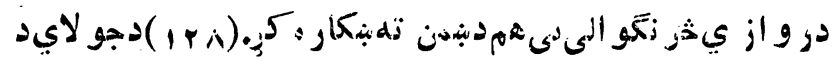

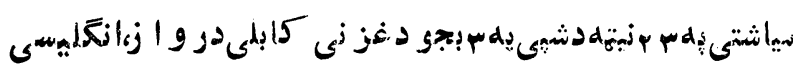

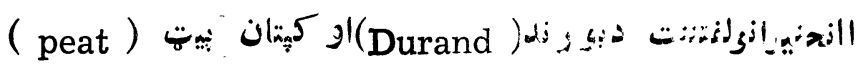

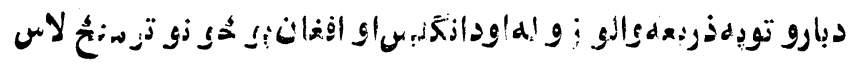

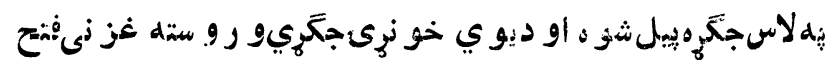

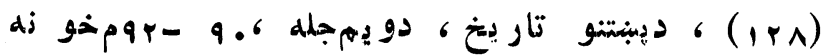

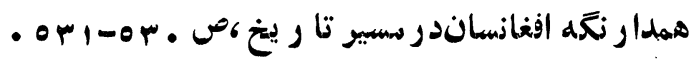




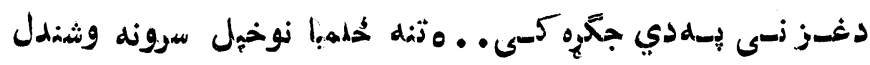

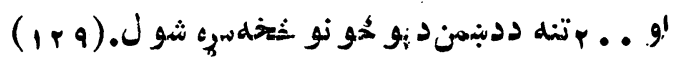

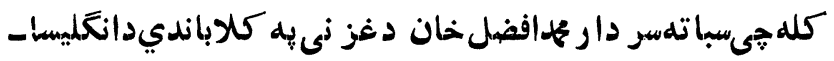

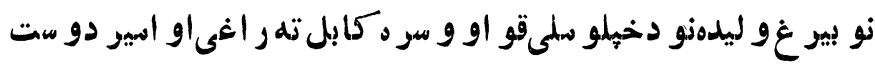

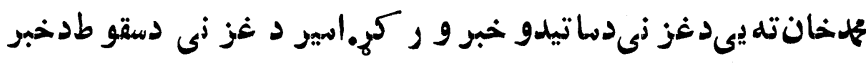

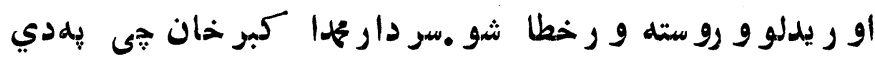

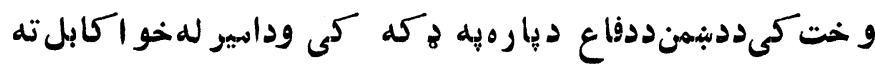

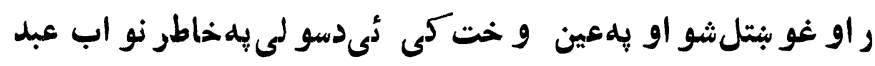

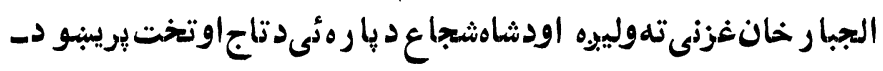

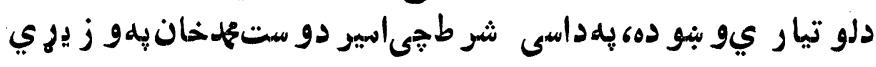

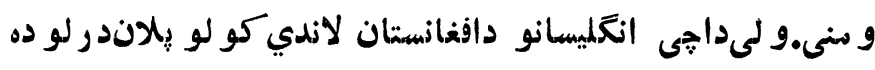

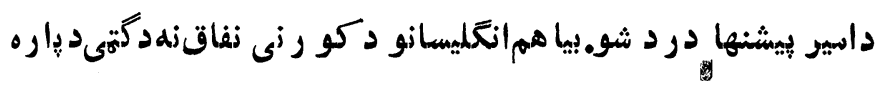

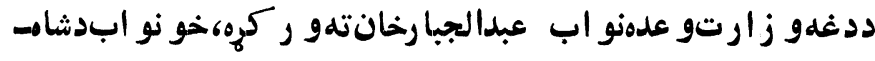

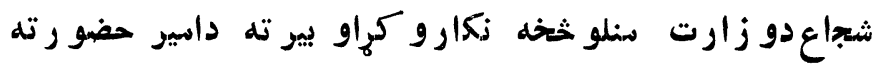

$$
\text { راغى. (rir) }
$$

اسير دو ستهم خان و رو سته تر ديجى و ضعيت يى بجو انىو ليده

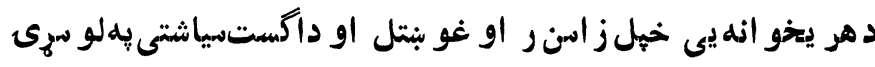

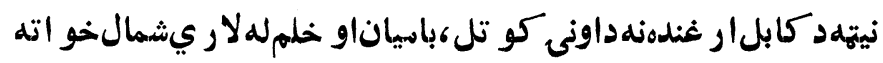
ته دبخار ا بهنيت رو ان شو •

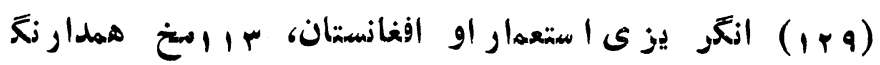
Arthur Swinson, North West Frontier, P 48.

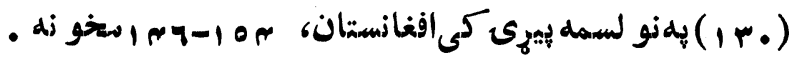




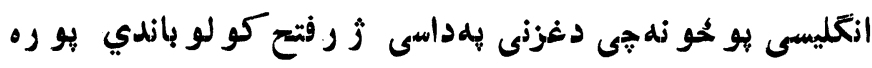
ز زو رشو ي و و دجو لاىددياشتى بيه ـ بنيتهدغز نى خخهد كابل يه لور رار و ان شو لبىلهدي جي بيهلار و كى دكو ممقاو متسر منخا

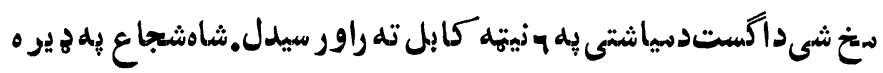

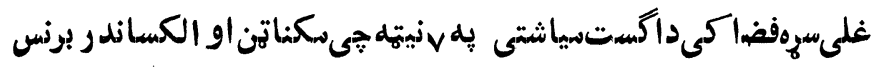
هم ور سو هنلكَر ي و و ددير شو كالو تبعيد و رو ستهبالاحصار ته

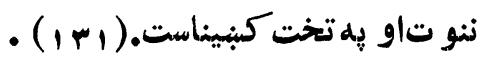

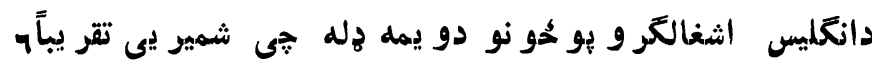
زرهتنو تهر سيدهد كيتانو يهاو شهز اده تيمو ر تر آو ماندى لاندي

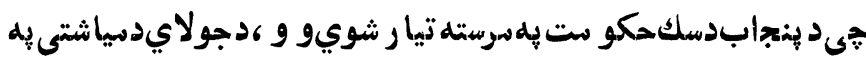

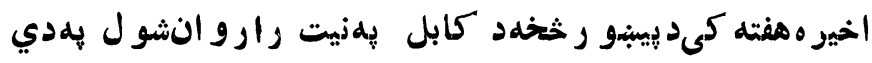

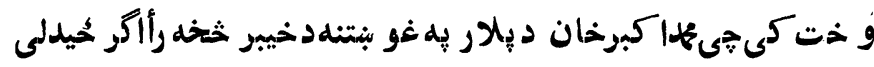

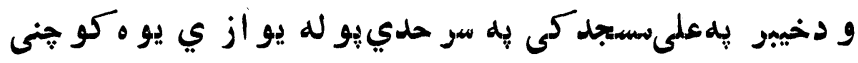
سر حدي قطعهمو جو دهو هجى دسر حدخخهل يیساتنه كو له.دجو لايد

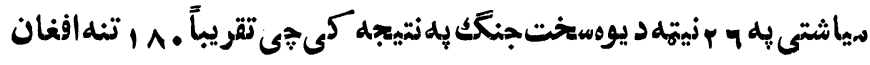

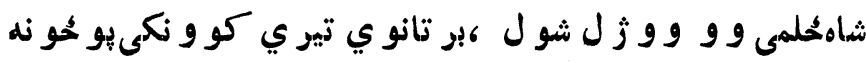

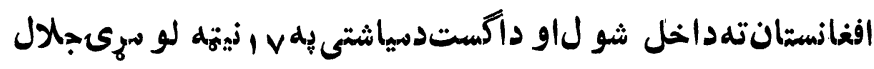
آبادتهاو د هغلحماينهدسيتمبردمياشتى يهم نيته كابل تهر او رسيدل

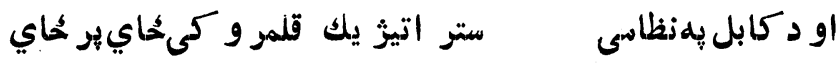

Louis Dupree, Afghanistan, P 378. 


$$
\text { شول . (imr) }
$$

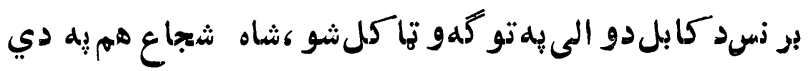

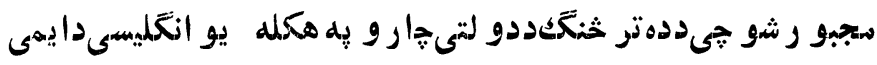

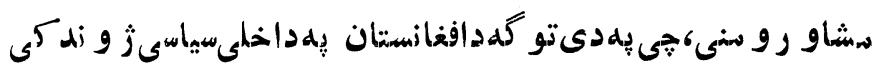
دتيو ي كو و نكو كنترول مايميده .

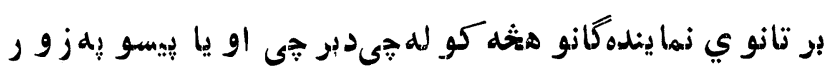

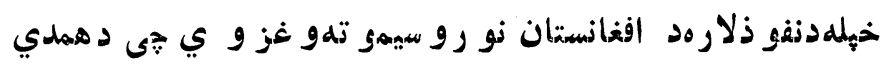

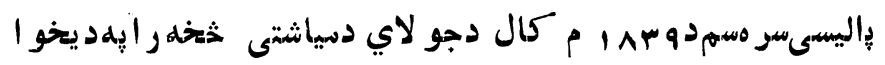

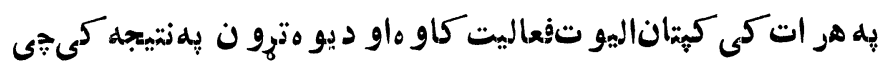

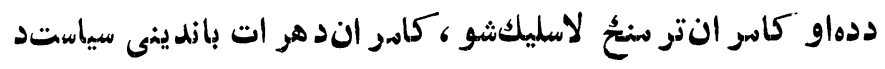

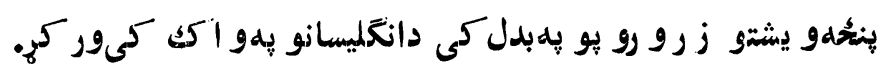
(ITr)

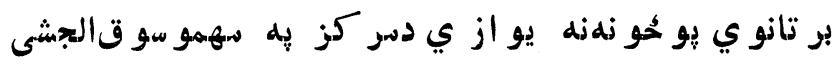

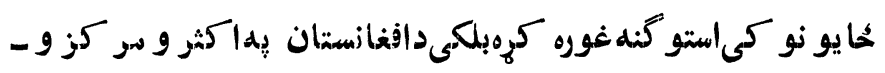

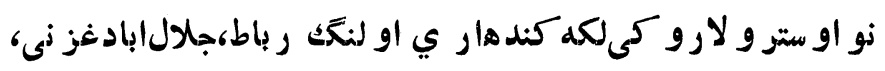

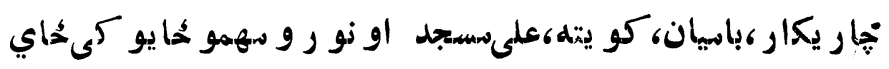

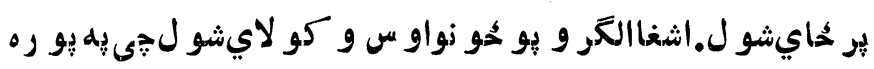

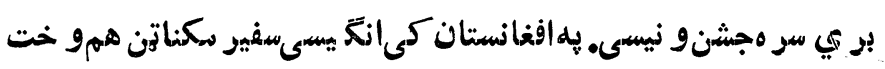

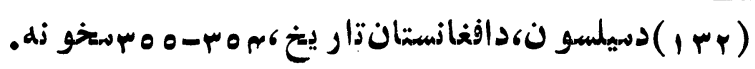

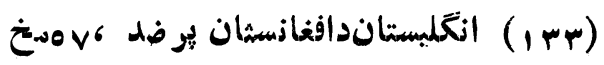


104 al

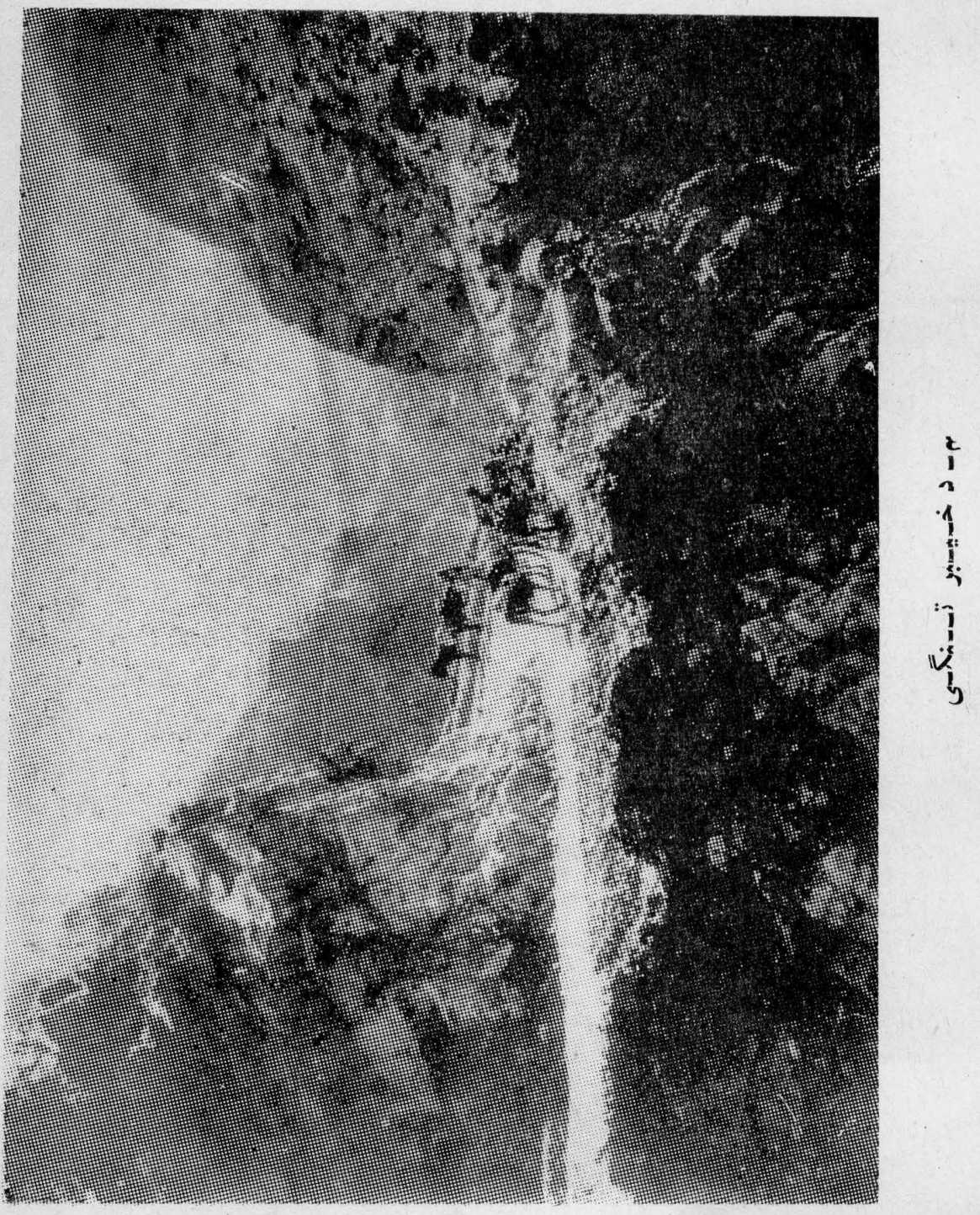


دهوختدبر تانو ي هند كو رنر جنر ال لار داكليندته او هغهبيا به

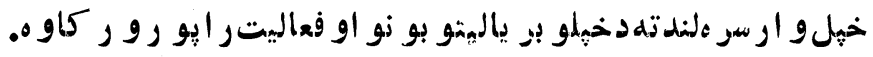

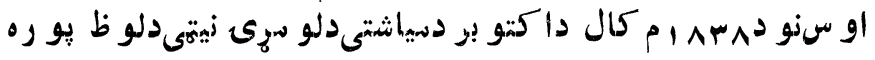
كو لو و خترانبرديشو ي و جيىلار د اكليندو يلىو :" كو مو خت

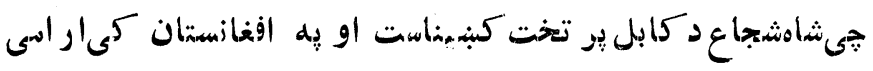

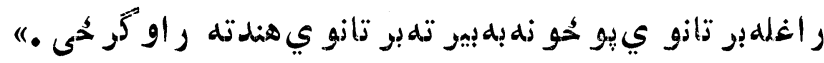

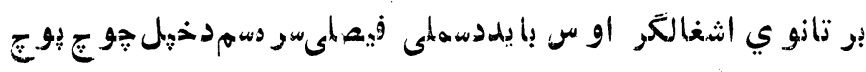

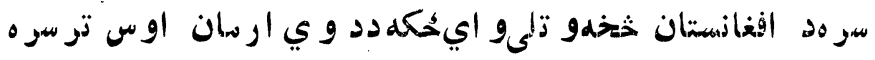
شو يو سلوزي شاهشجاع دانكليمانو نبودي دو ست اوسدكابل ير تتختناست و .دهند كَو رنو جنر ال لار دا كلينداو دكناتينددي

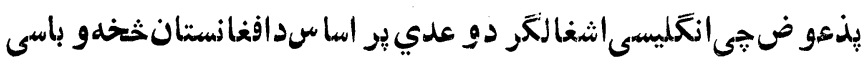

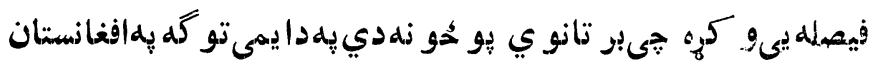

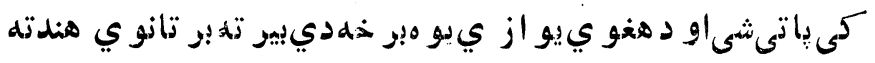

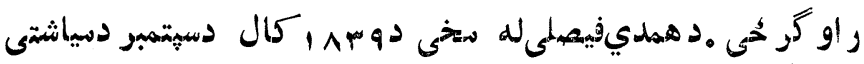

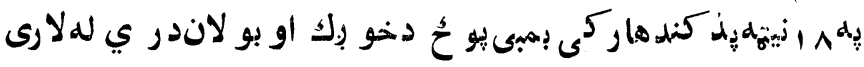

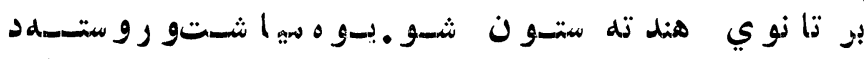
اكتو بر دسياشتى يه ه إنيتهد بمبئى بو خح يو هبلهبر خلدسو جان كين تر قو ماندي لانديدنيبو در ي لهلار ي حر كتو كراو يلهينسوقع كىيى

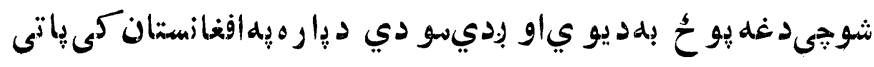


شى. همدار نَكَدسر جان كين يهعوض سيجر جنر ال سر و لو بى كاتن

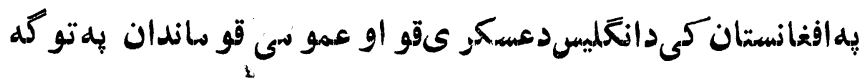

$$
\text { دقر رشو • (هrri) }
$$

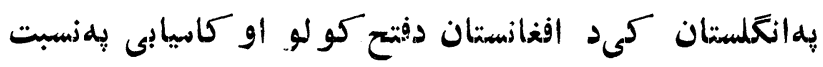

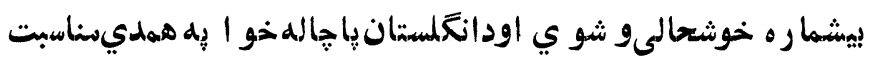

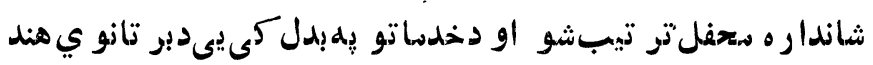

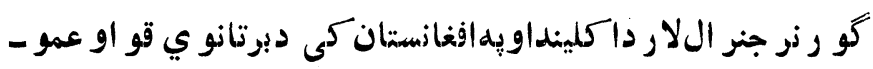

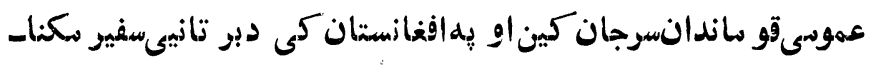

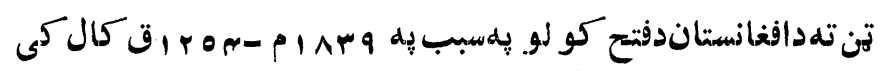

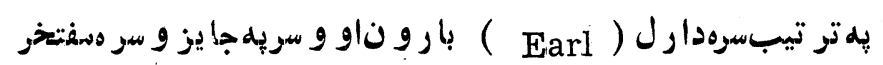

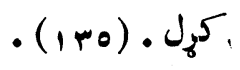

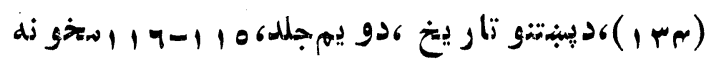

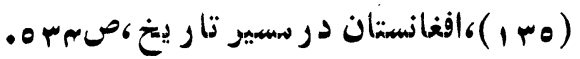




\section{شيرّمصل}

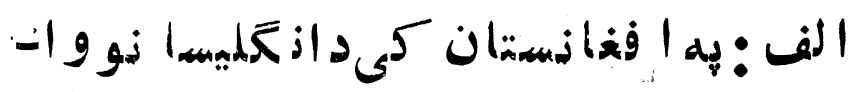
.05

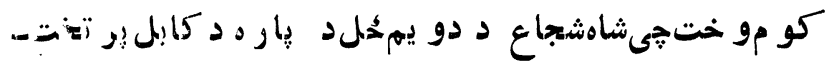

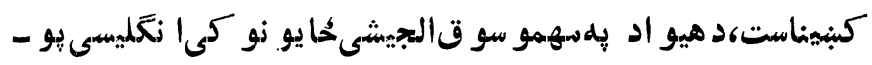

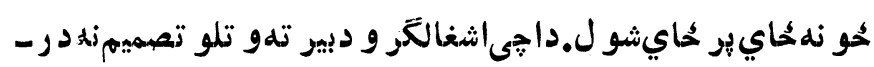

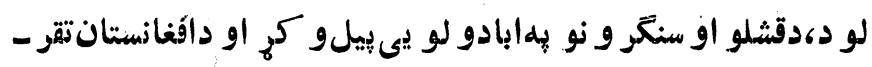

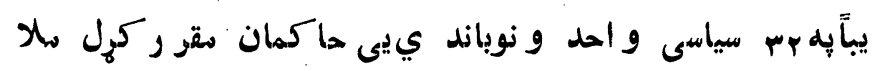

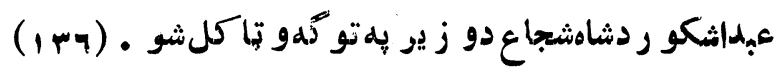

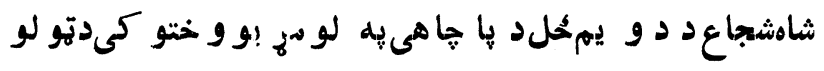

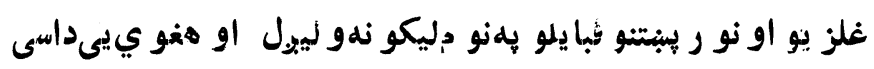

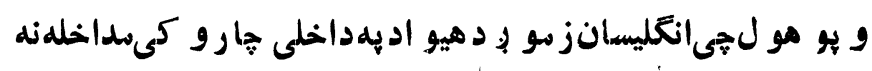

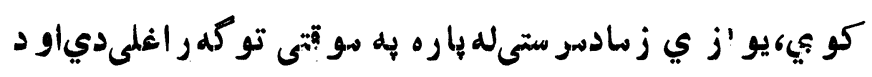

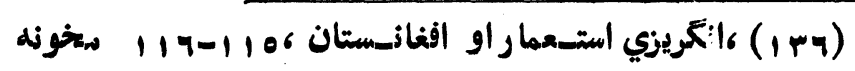




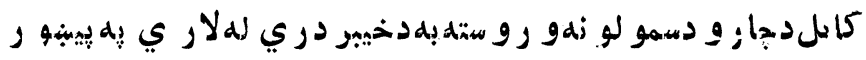

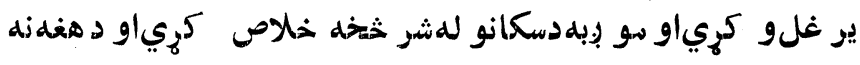

$$
\text { و رو سته إلهندو نثةانته و لارئى.(rv }
$$

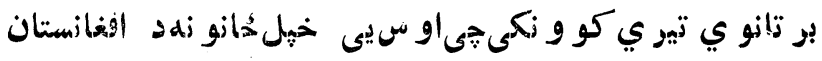
سالكان كنهل عملاً يى داوغانستان

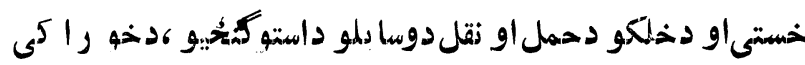
مو ادو او شخصى شتمنيو يهضبطو لو او لو توى لو يىلا س بو ر بيكي

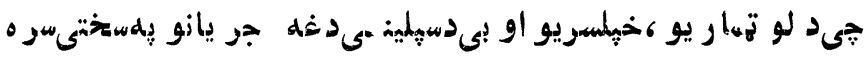

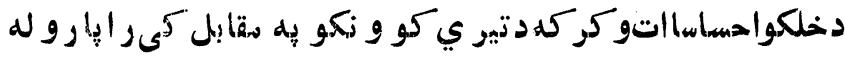

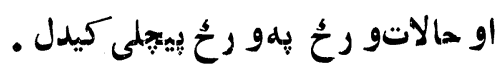

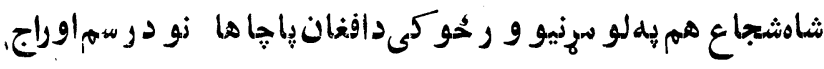

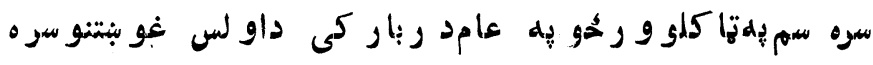

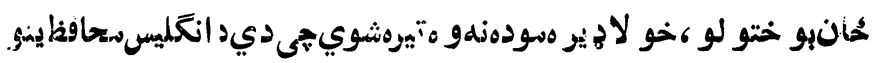
يلهذر يعdنحاصو هشو او دانَّليس افسر انو لهاجاز ي يو ته هيث افغان

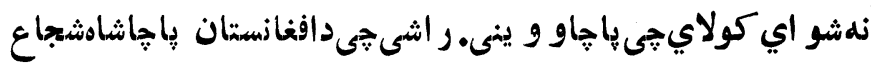

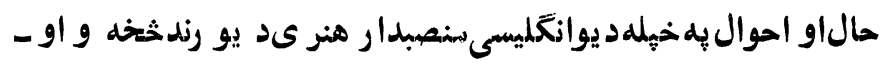

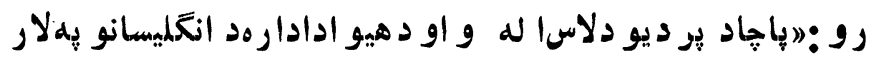

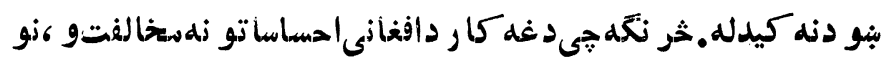
•

$$
-1 \cdot 1-
$$




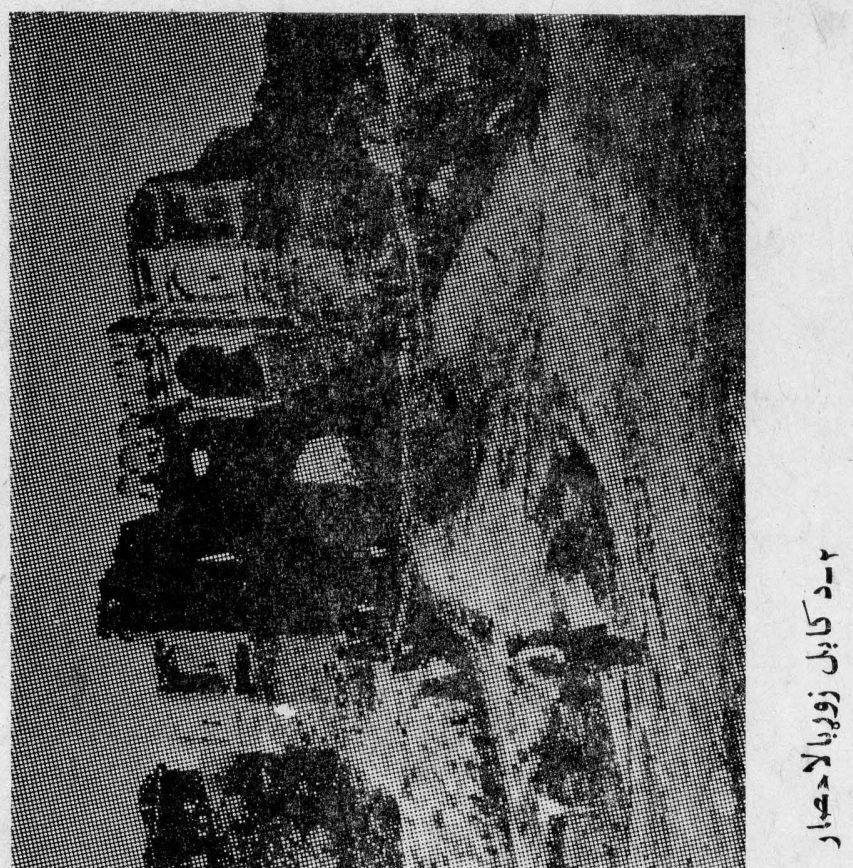




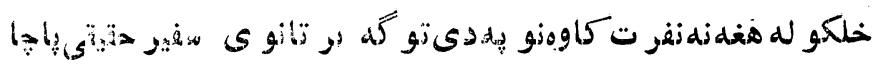

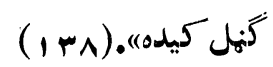

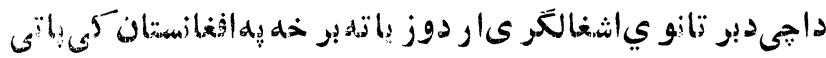

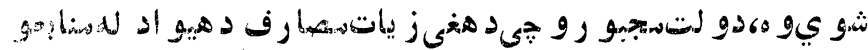

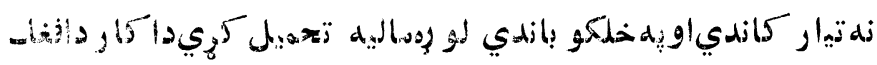

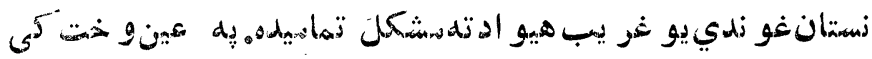

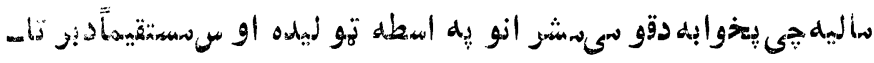

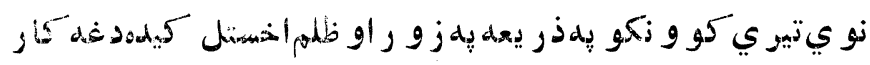

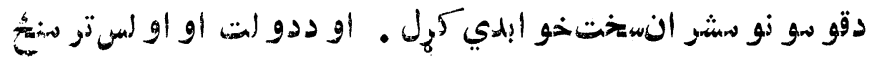

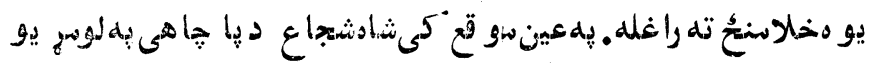

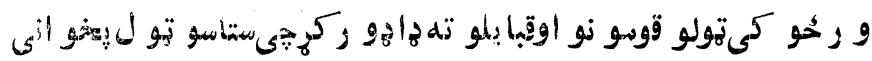

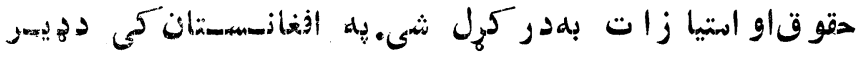

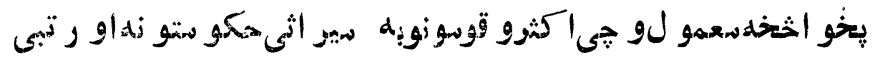

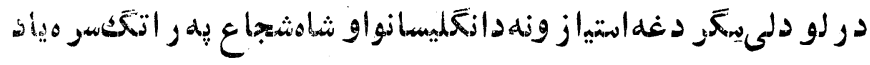

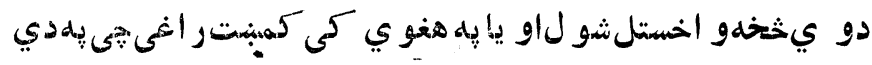

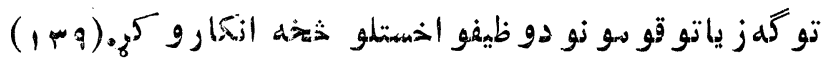

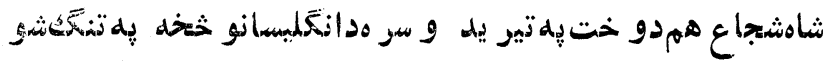

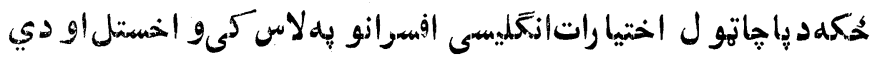

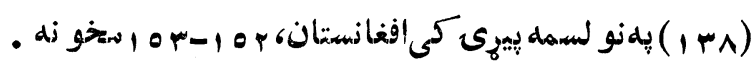

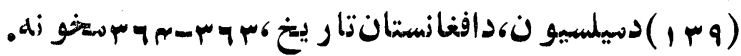




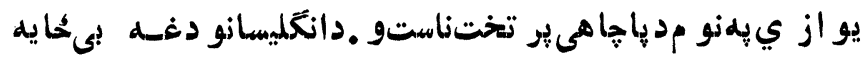

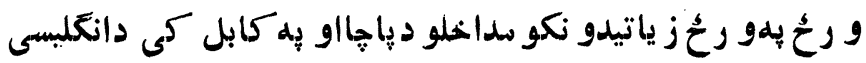

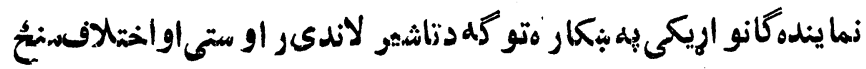
راغى.عاسو خلكو ته هماو سيله يو رهتو گهبنكار وشو هجى شاهشجاع

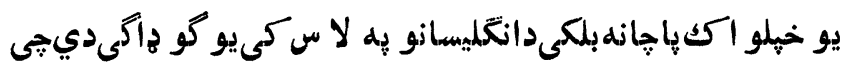

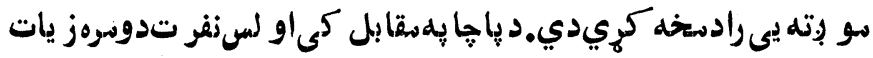
شو جى حتى دجاسع جووا تونواساسانوبه خطبه كى دشادشجاع نو ماخستل

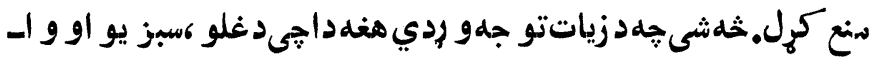

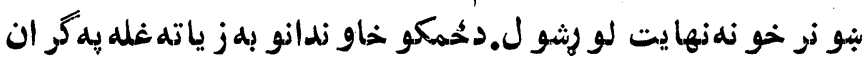

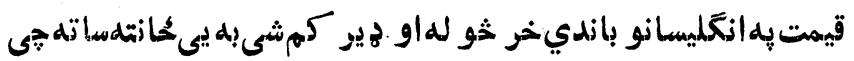

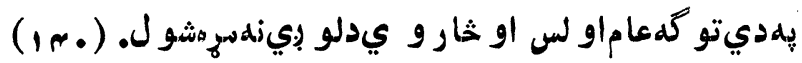

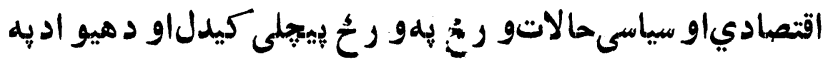

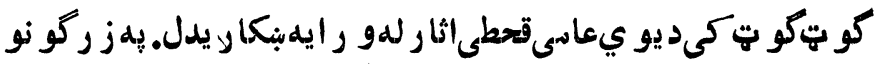

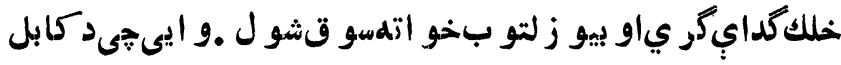

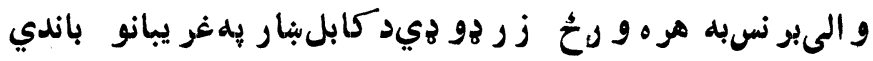
تقسيمو لى.البته داد هغى استثمار بو كتؤجهىبوتانو ي استعمار جـيانسو دافغانستان او لسته يهار دغانر او ريو .ملاعبدالشكو ردشادشجاع

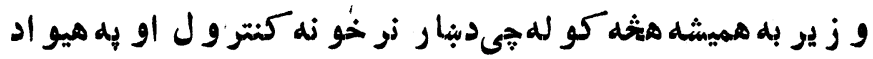

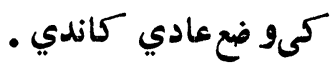

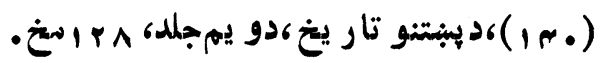




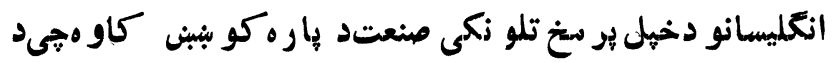

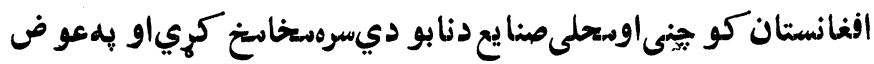

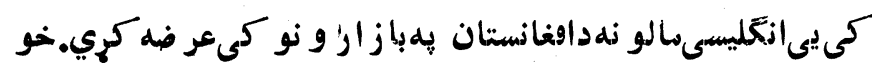

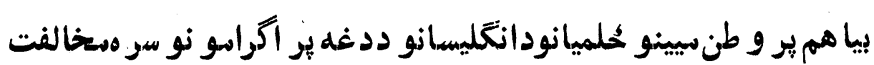

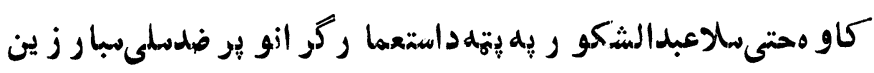

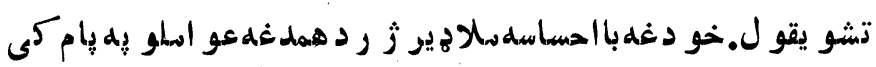

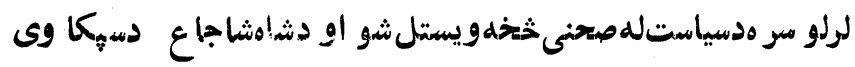

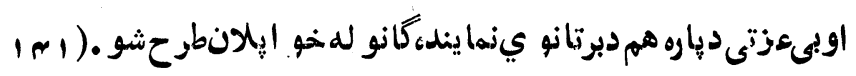

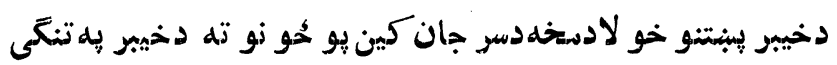

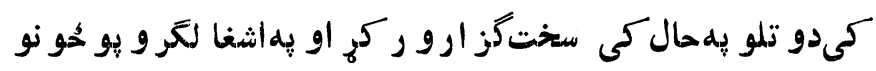

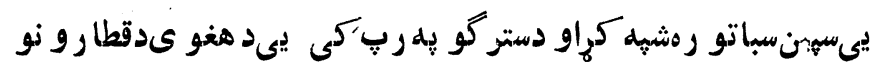

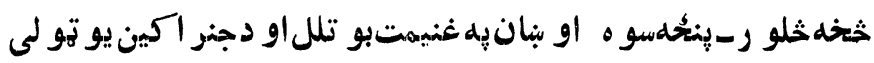

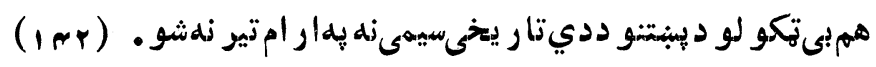

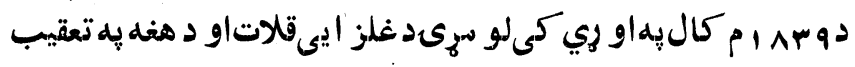

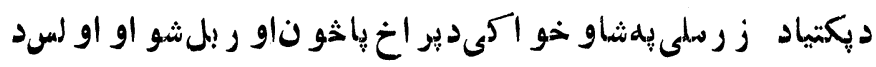

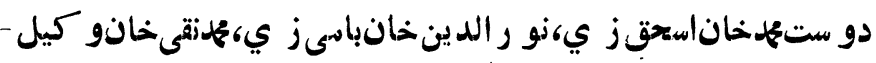
او مهتو سوسى خانغلز ي يلهسشر ىداثشغالَّر و بر ضدر ايو رتهشو جى هميشلبه يیى كابل او كندهار دتغكاو ر اتخكلار هتوهديدو له .

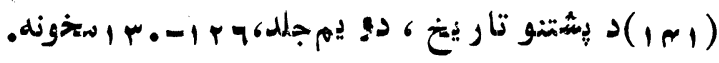

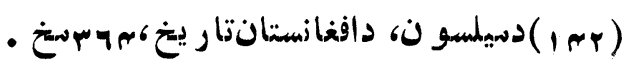

$$
\begin{aligned}
& -111=
\end{aligned}
$$




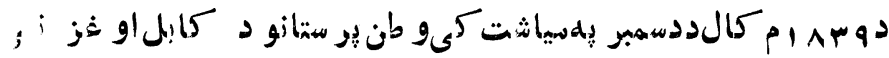

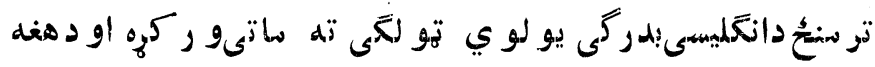

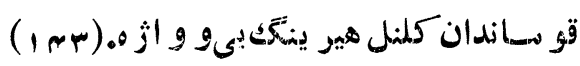

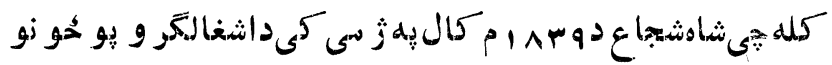

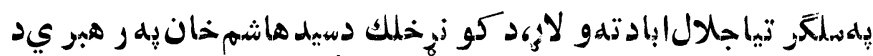

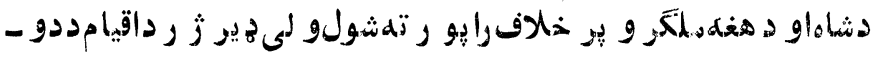

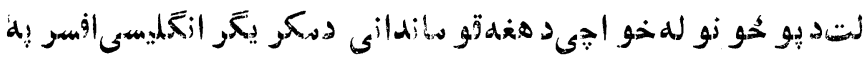

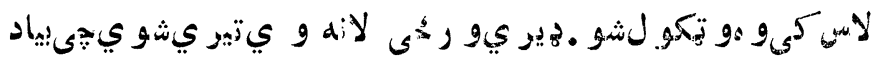

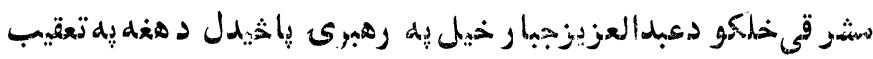

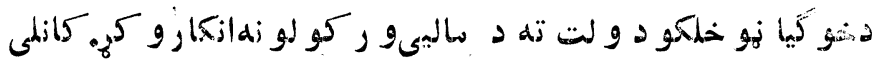

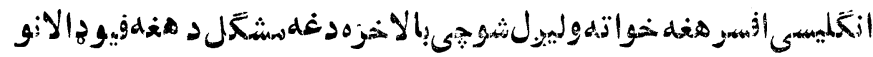

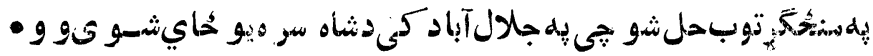

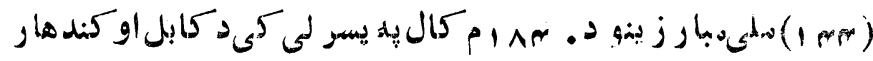

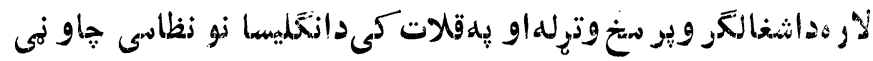

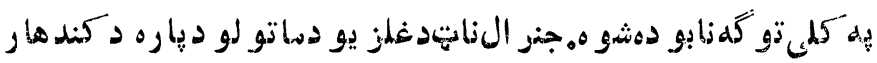

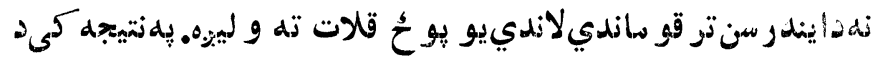

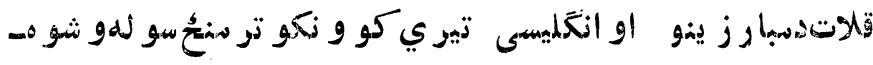

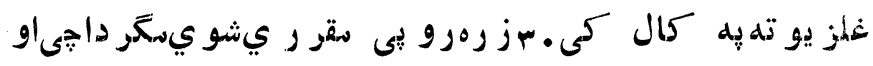

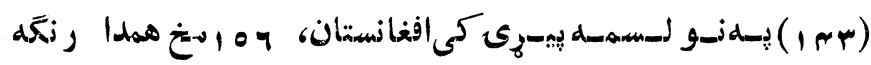
Afghanistan Past and present, P 102-103

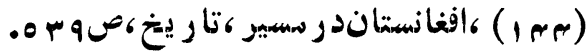


او لسداستعمار كر وُ بو خو. نو. بهمقابل كىنها يتتحو يك شو يو و د دو ي دأبلاناو هيخ همدناكاسى سر هديخاستخ شو ياو هير ز ربياد

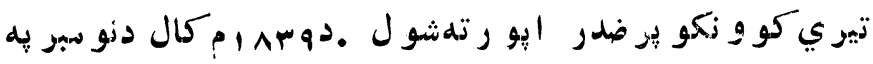

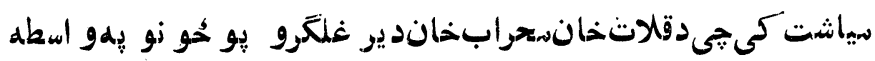

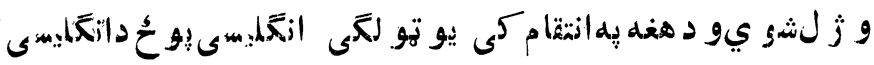

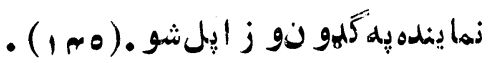

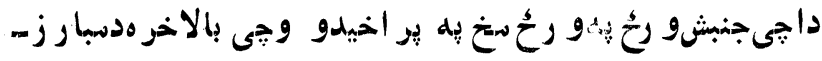

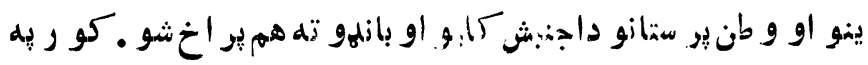

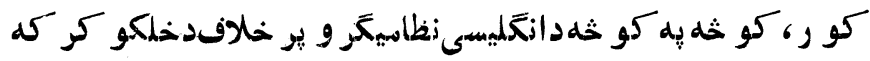

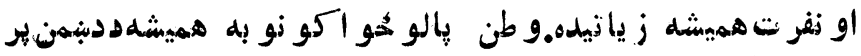
قشلو ،قطارو نو او كارو انو باند ي يز غلو ندكول او ددو ي يخدد

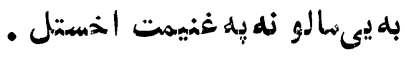

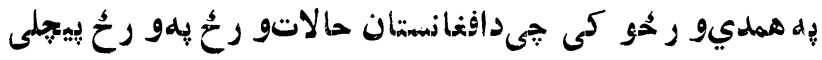

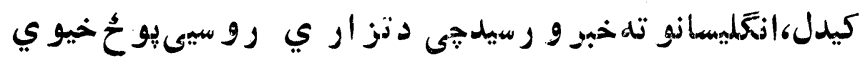

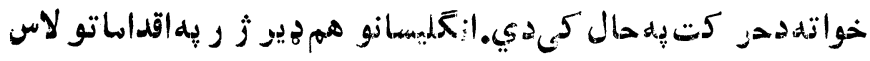

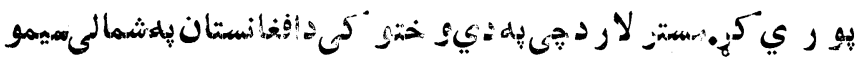

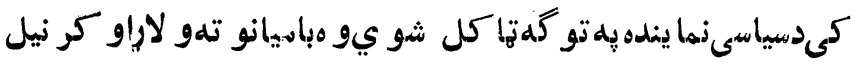

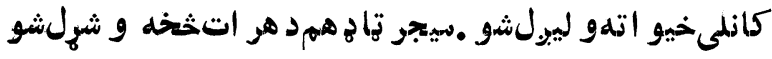

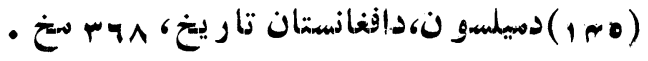


انغليسانو و زه كرايشو لجه يار مُخخانالمكو. زي سر هيو ترو نلا -

$$
\text { سليك كري. ( ه بـ 1) }
$$

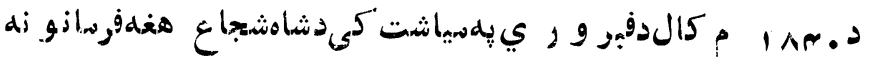

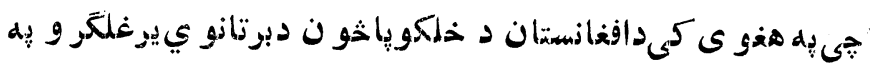

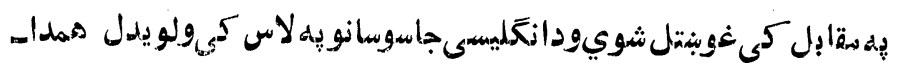

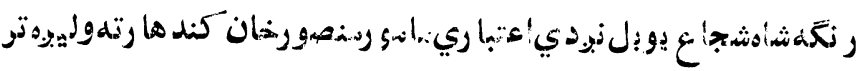

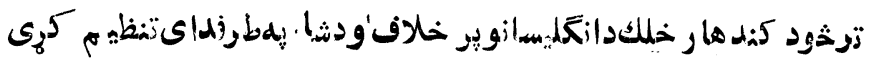

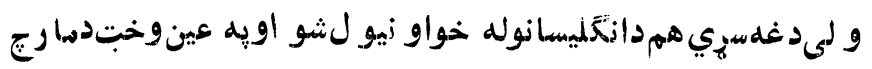

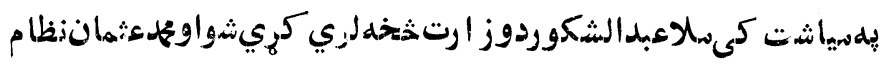

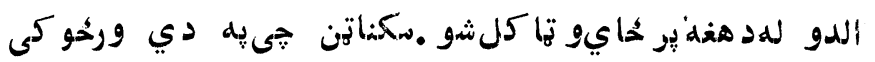

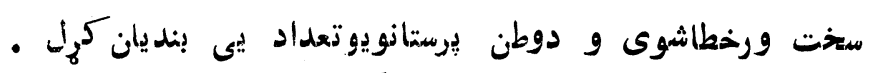

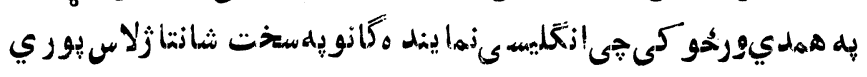

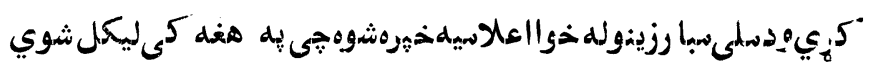

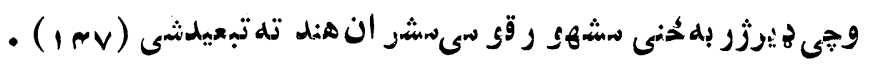

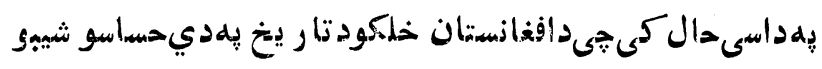

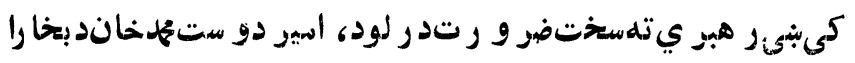

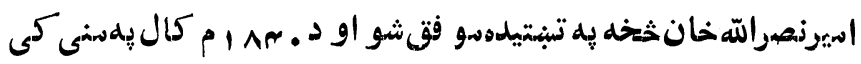

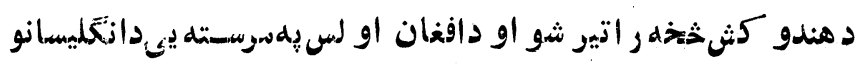

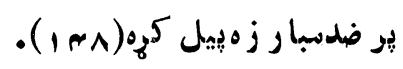

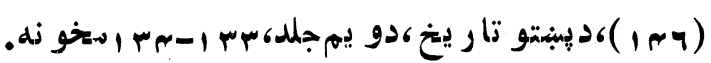

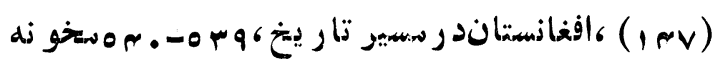

(48) W.K. Fraser Tytler, Afghanistan, P. 114. 
ب : د افغانا نو مقا ومت او د ادير دوست-

\section{متحمل خان تسميلميدلن:}

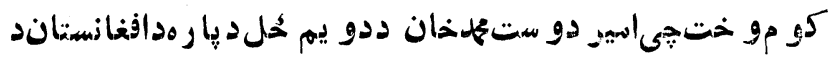

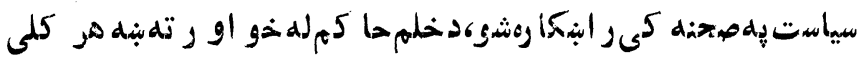

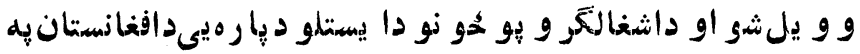

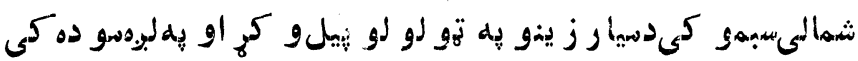

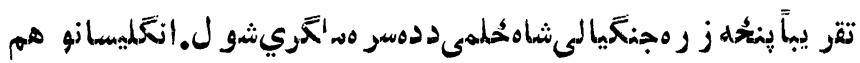

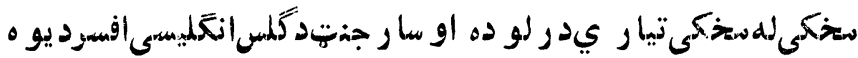

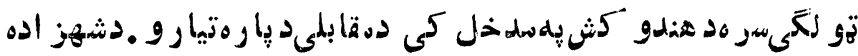

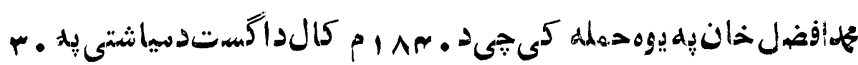

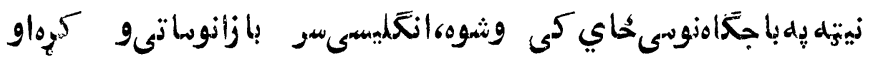

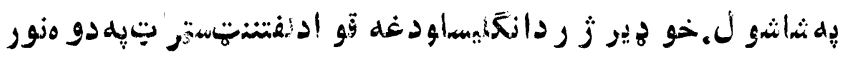

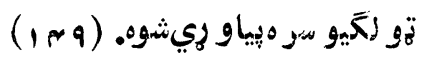

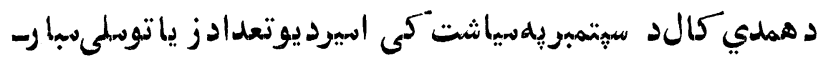

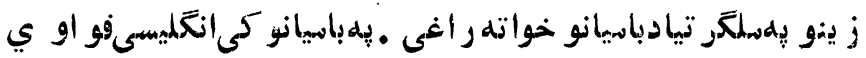

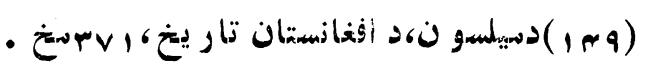




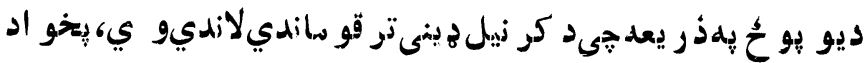

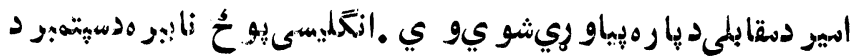

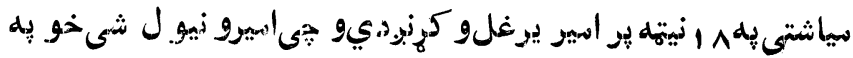

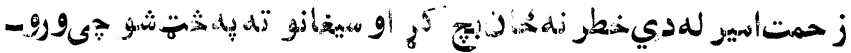

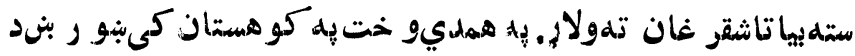

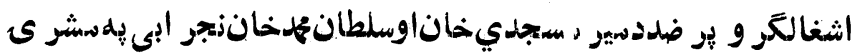
ر هبر.ي كيده.اسير هم دليكإه و اسطن كّى هستانتهدعوت شويو.

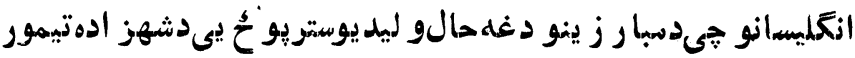
دشاهشجاعزو زوئاو جنو السيل( Gieneral Sale تر قو ماندي لاندي هغdخواتهو ليوبهاو سر بير ه بر دي بيدبنو رش كونكو دشر انو

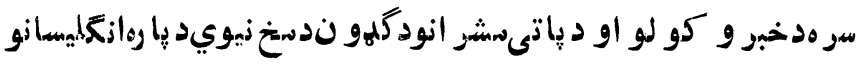

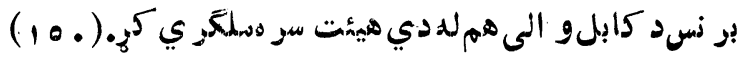

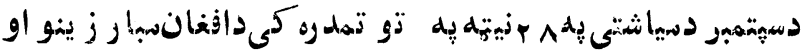

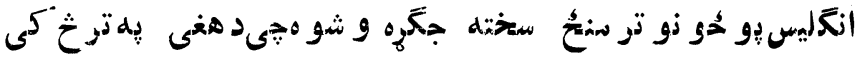
-

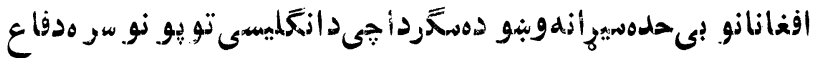

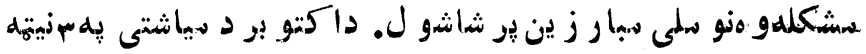

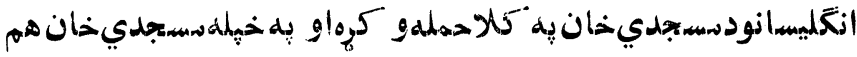

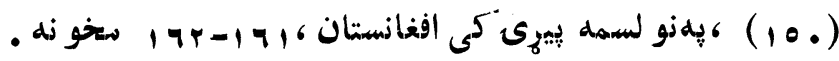




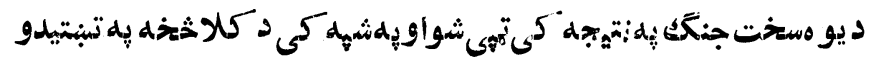

$$
\text { سر همو فقشو . (101) }
$$

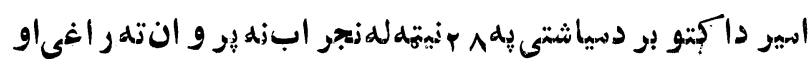

دجهاد بِّ نو مسر ثيىخلك راتو لو ل. بِه همديوخت كى يو تو لى افغاـ

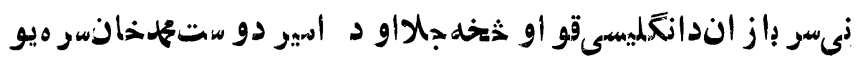

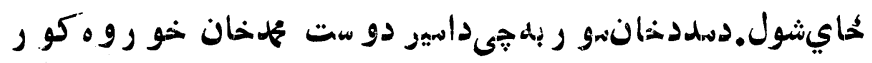

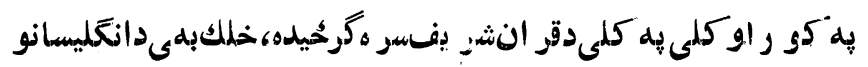

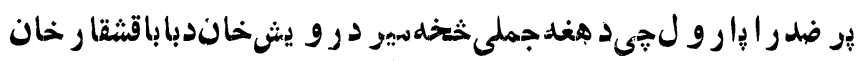

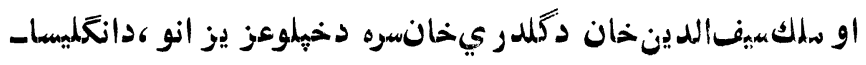

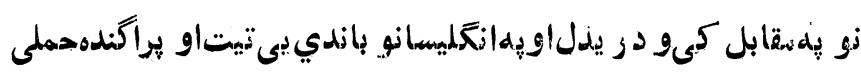

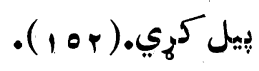

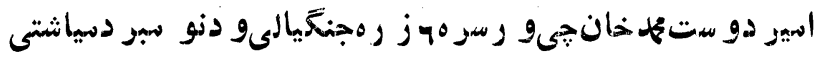

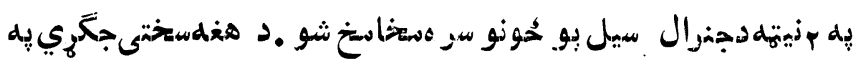

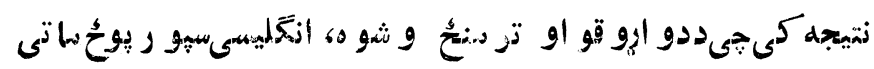

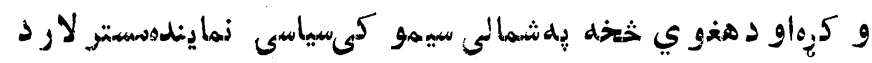

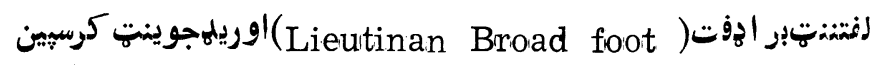

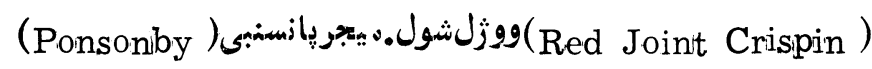
او ديجر فريزل (Major Fraqzer) ستخت تهيبان شو ل.دانغليسى

$$
\text { • }
$$

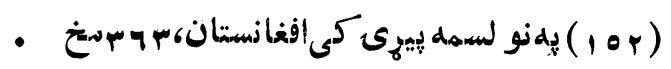




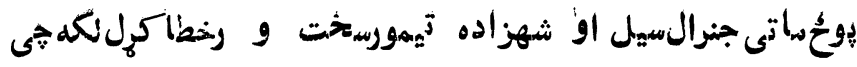

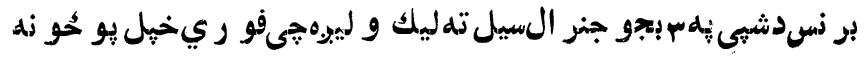

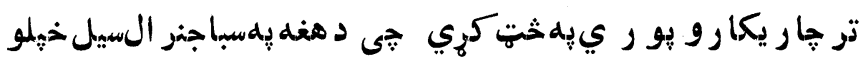

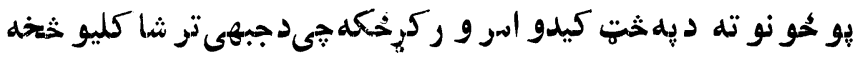

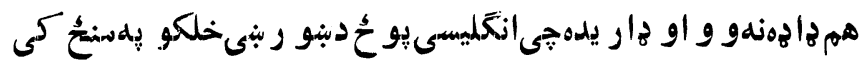

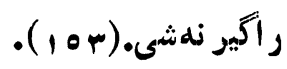

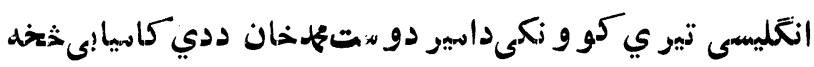

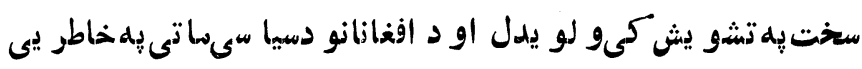

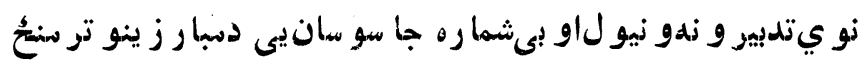

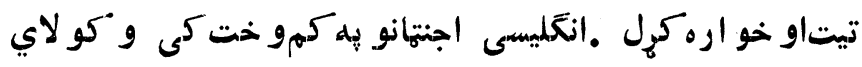

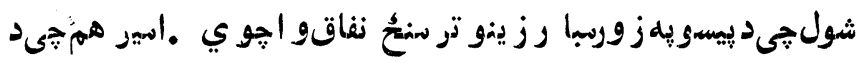

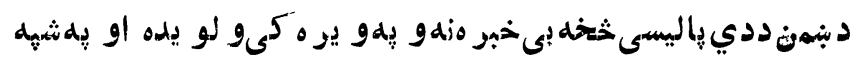

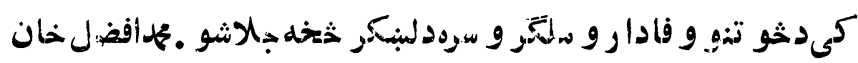

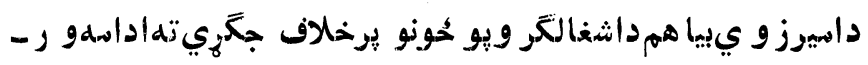

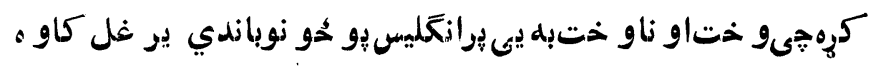
(104)

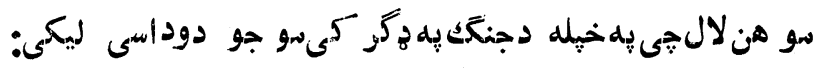

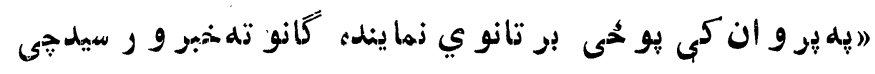

•

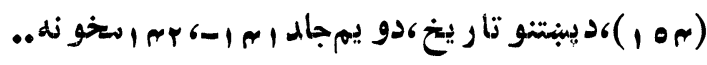




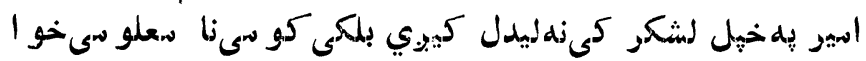

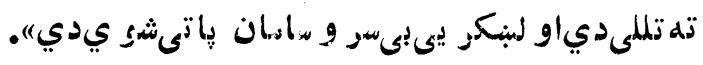

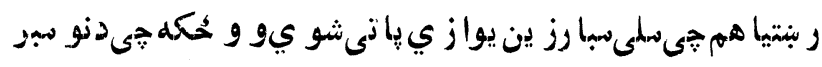

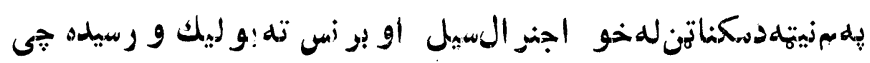

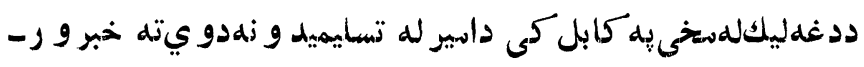

$$
\text { كريشوي و. (100) }
$$

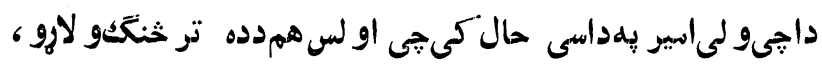

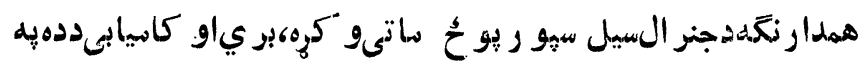

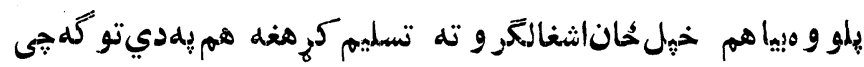

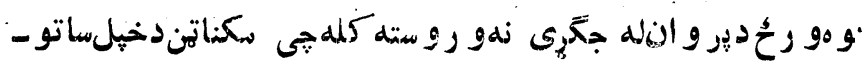

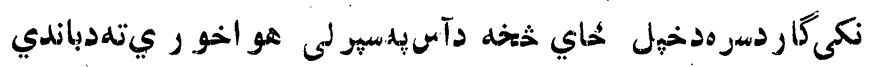

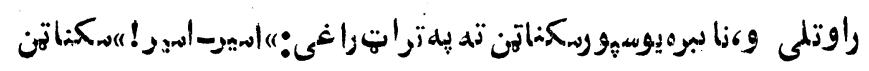

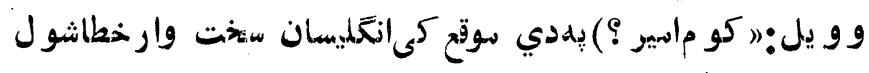

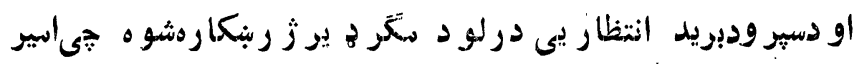

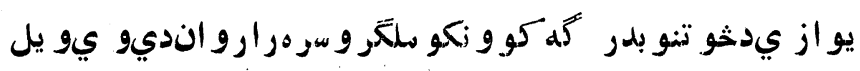

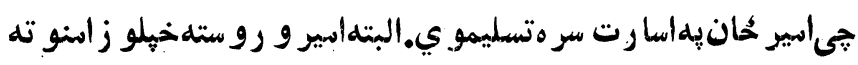

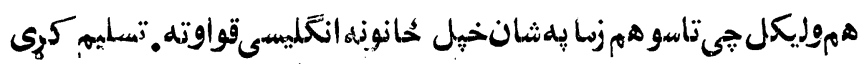

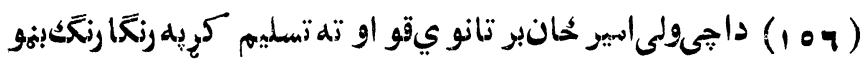

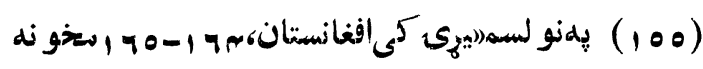

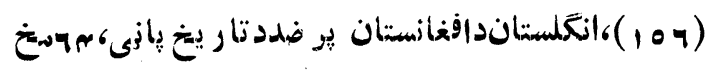




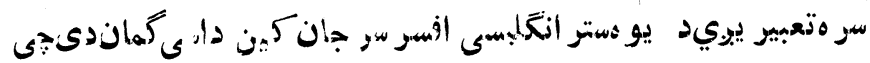

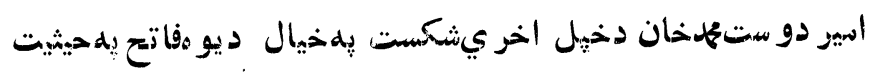

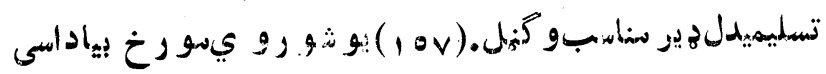

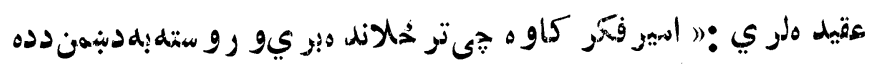

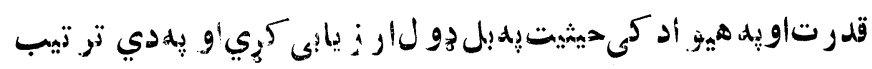

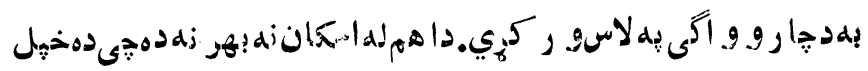

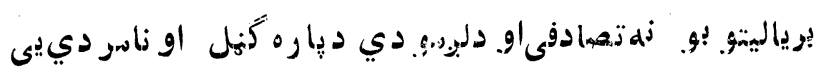

$$
(101) \cdot 110,89
$$

$$
\text { حينىنو. ونم. رخين داسى ليكى : }
$$

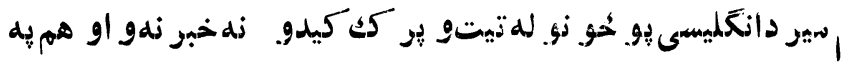

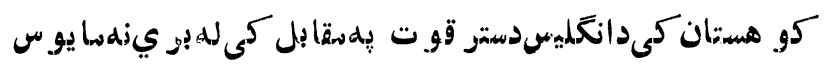

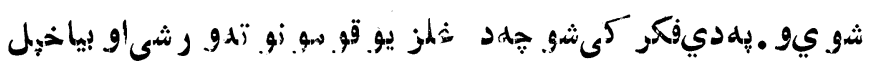

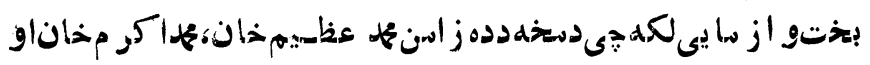

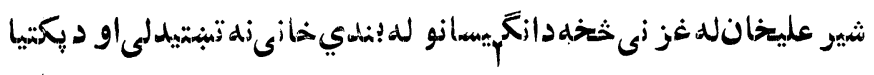

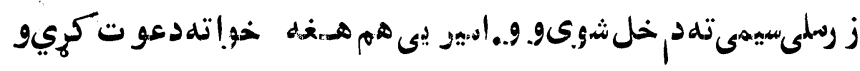

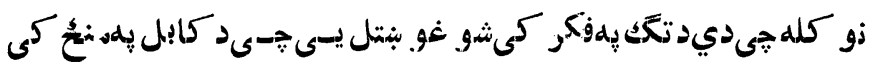
تيو شىاو لازميىو ليدل يىخو ككخـبر زه كري او يو أز يدجامو

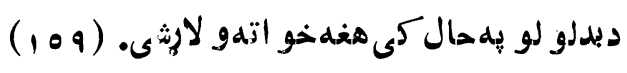

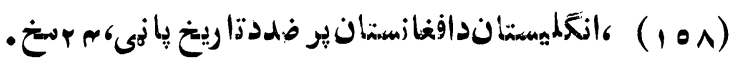

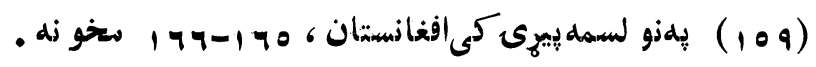




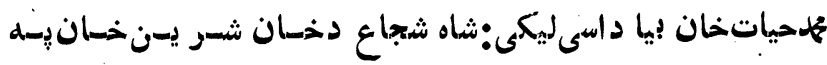

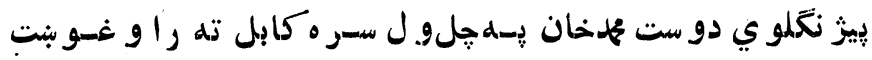

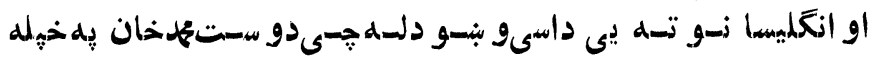

$$
\text { راغلى دي. ( • 19) }
$$

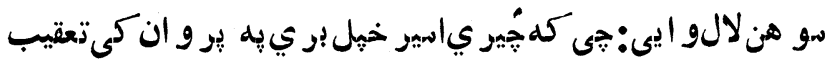

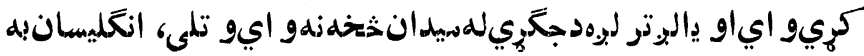

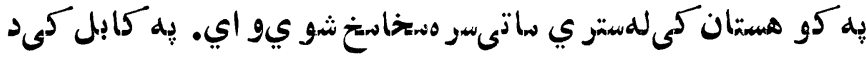

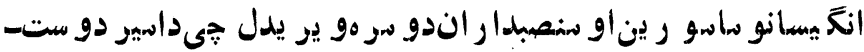

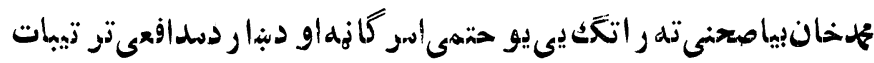

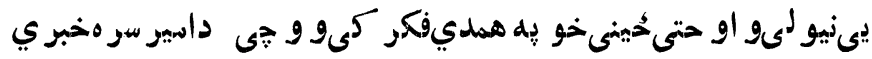

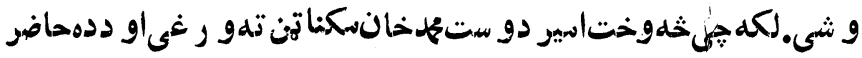
باشتهيىوو يل-و رتهو وايهجى اديو للهاسو هملاقات كو ي.نكناتن يه

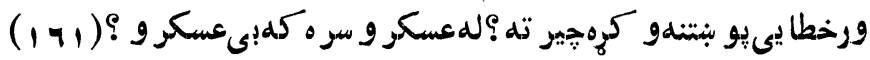

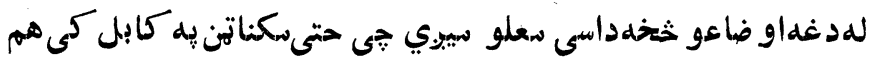
داسيربنكار يدل دنسلىبار ز ينهو او او لسسر هانتظار درولو د ـ

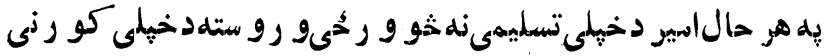

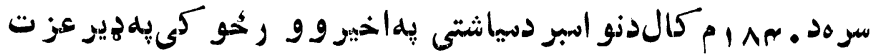

•

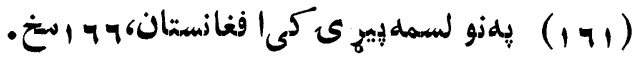


او احتر ام مر هد سرولو بى كاتن Sirwiloughby cotton)

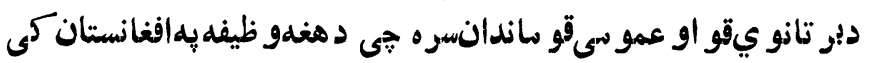

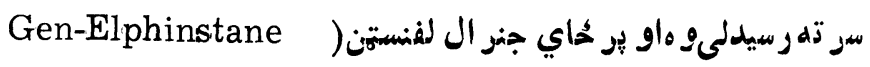
مقر رشو يو كلر تانو ي هندتهو لييلنشو.( به 1)

J.G. Eniot, The Frontier, London, 1968 P22, (162) 


\section{اووم فصل}

\section{الف:دافغانستة اندخمإكوملى ياخون}

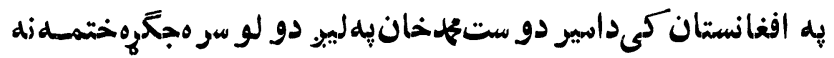

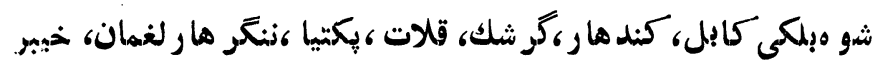

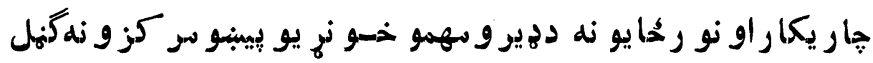
كيدل .

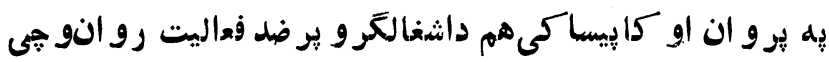

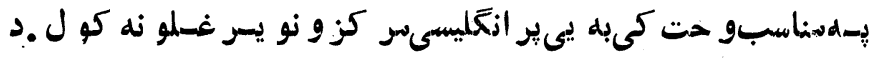

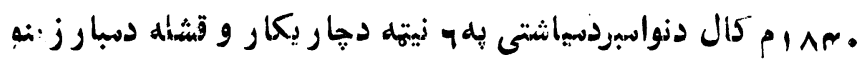

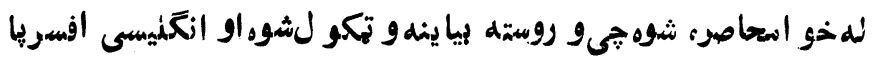

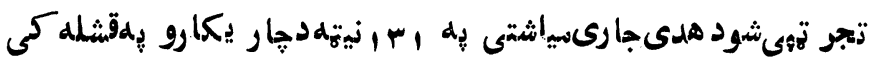

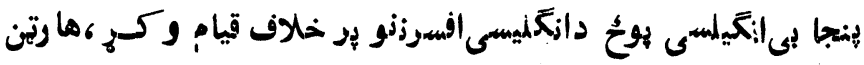




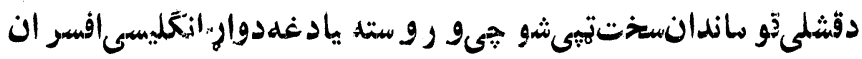

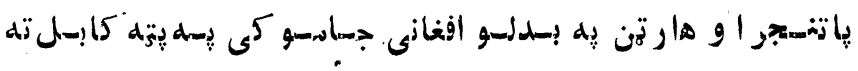

$$
\text { راغلاغل. (17r) }
$$

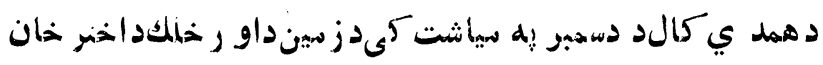

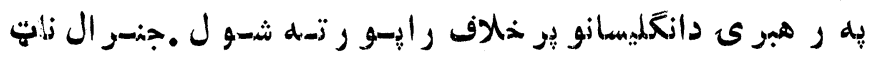

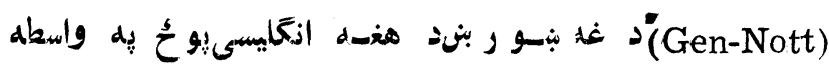

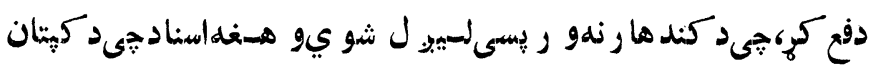
رالنسن (Capt-Rawlin son) انعَليسسى افسر لاستهو رغلى

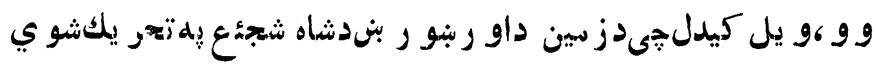
ديجىو رو سته بيادغه اسناد مكناتن ته ر او لييو ل شو ل .دكناتن هغه بياشاه شجاع تلو بنو. دل.( مه 1 )

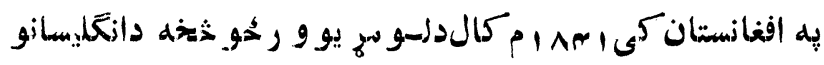

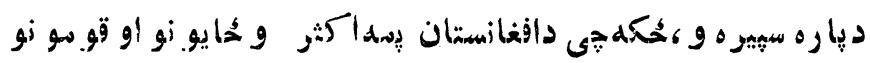
كى داشغالكر و بر ضدتيحر يـك او جنبش رو ان و .او د اسمه ا م كالد جنو ر ى يهنياشت كى افر يديقبا يل دانكليسانو يهمقابل كى رايو ر-

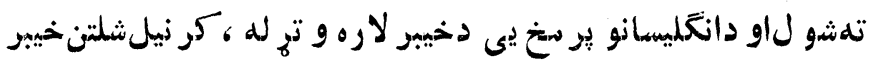

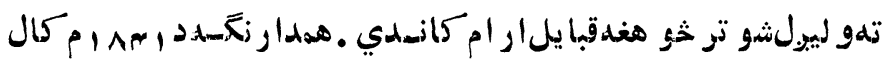

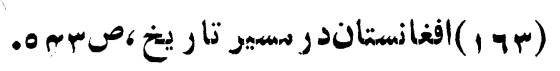

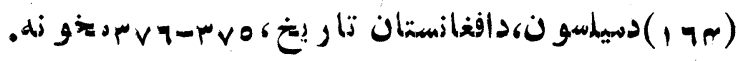




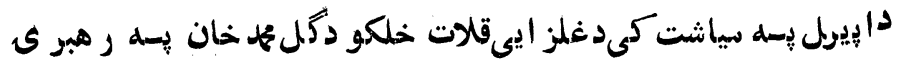

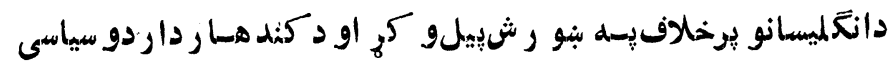
نما يندمسترليج دنظامى تفتيش مخخديى و نيو له خو و رو سته بياجنر ال

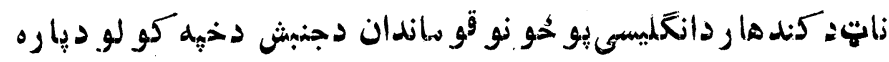

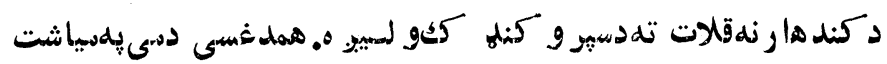

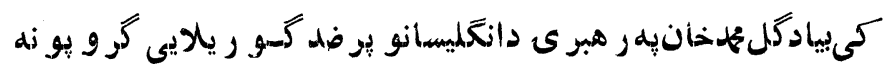

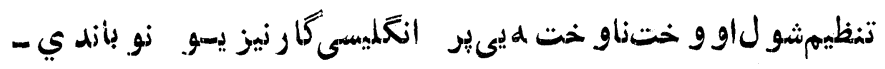
بريدونه كول ل.دافغانستانيهز يساتو برخو كى دانكلـيسانسو بر خلاف

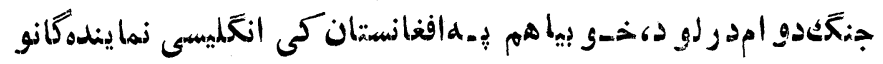

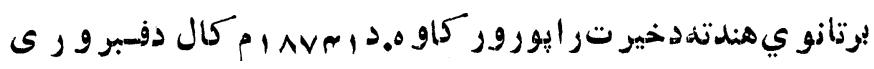

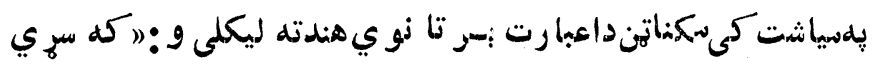

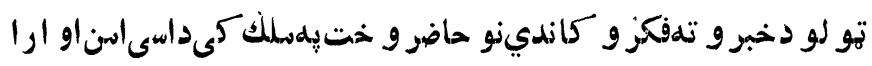

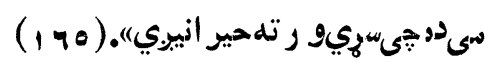

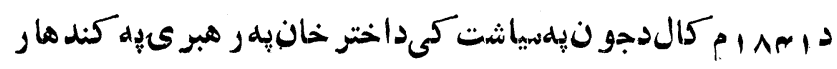

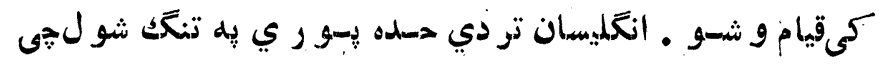

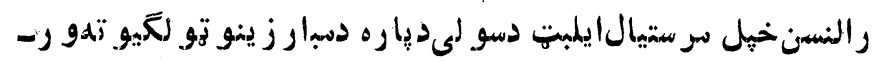

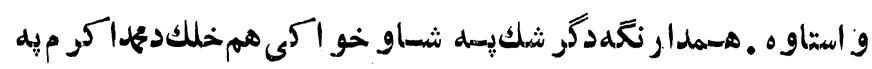

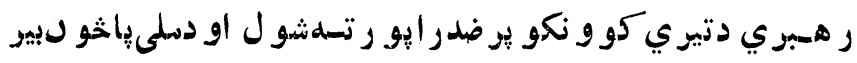

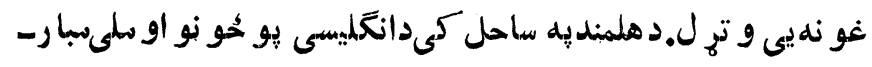

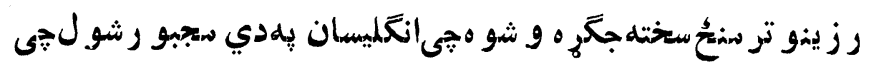

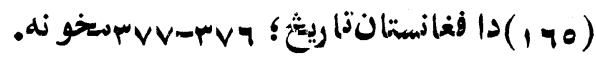


دكندهارنهنو ربو محو نهدشهز اده-صفدرتوقو ماندي لاندي هغd

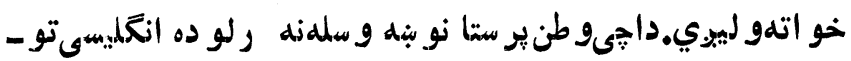

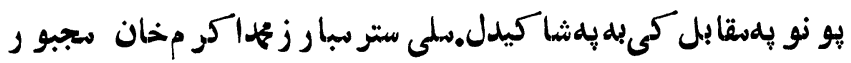

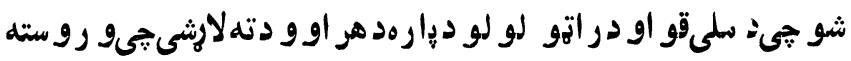

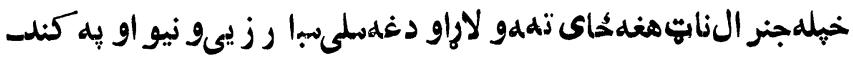

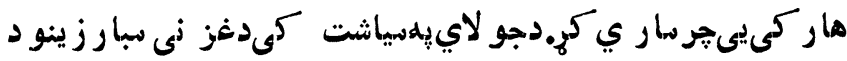

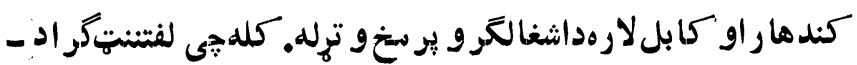

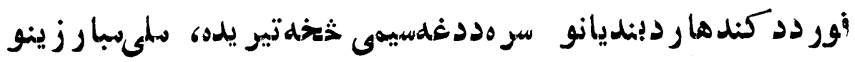

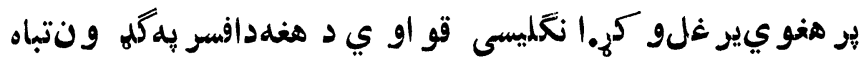

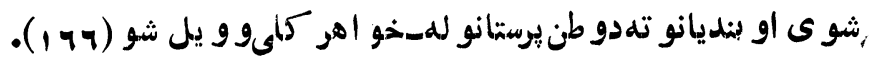
دحير انتيامحايخو دادي جيىدديحالاتوسودسره جيىد ا فغانستان

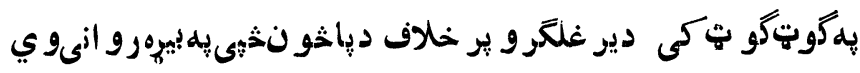

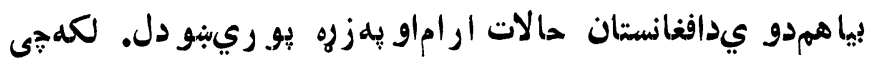

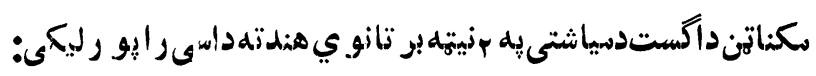

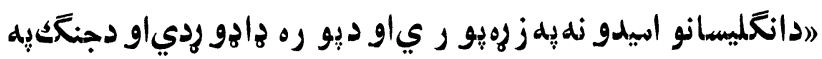
كو مساسانجىزمو بونسوه شتهدتو لمبلك بنهساتنهاو انتظام كيدايشى"

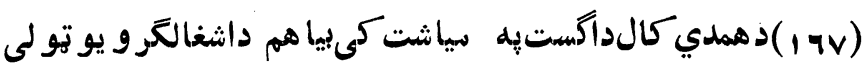

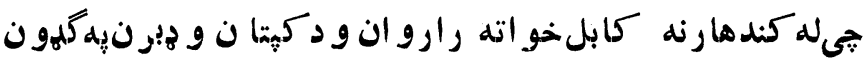

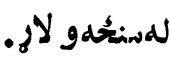

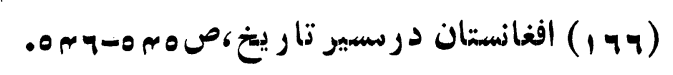

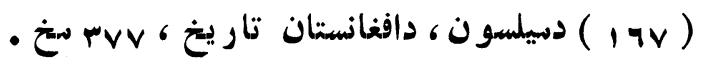


دِهه افغانستانكى انكليسى نماي-نده كانسو هميشه سعى درلو ده

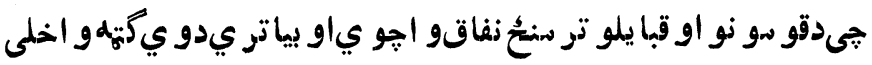

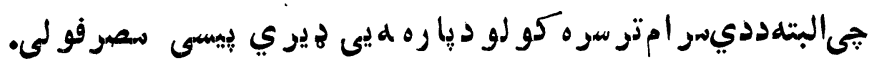

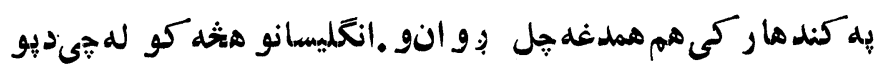

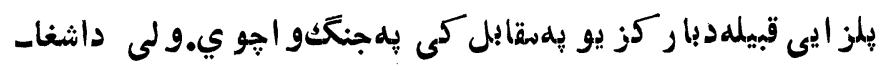

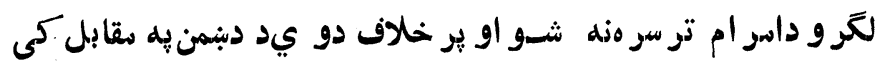

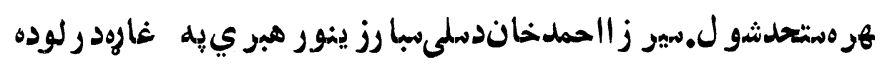

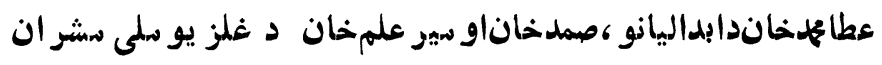

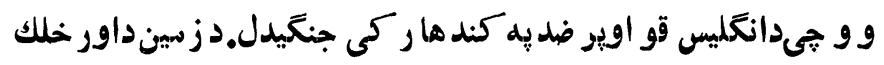

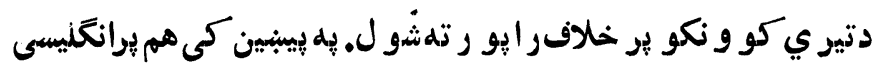

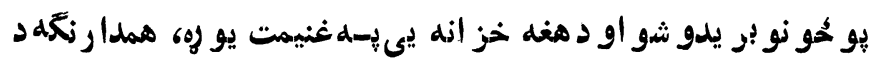

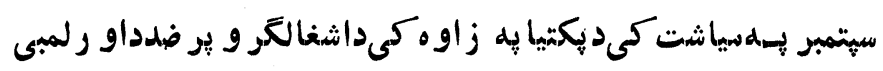

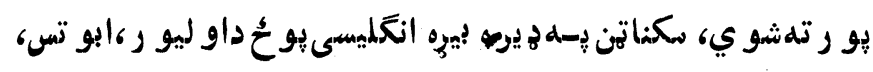

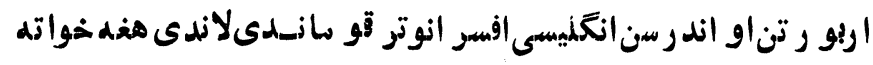

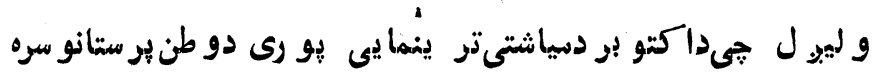

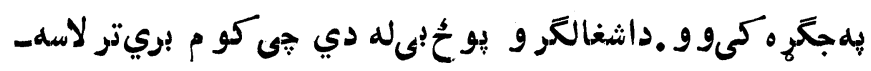

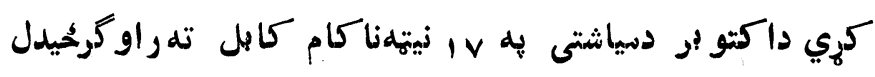

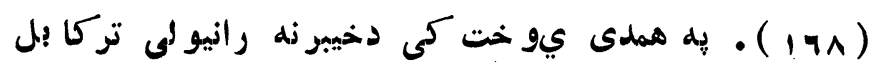

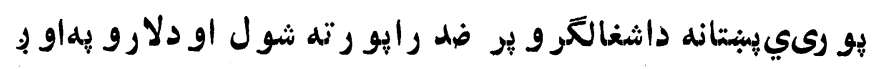

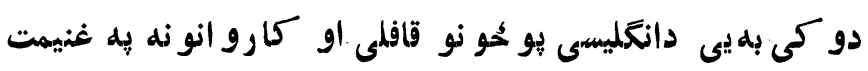

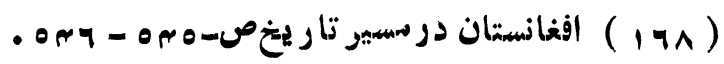




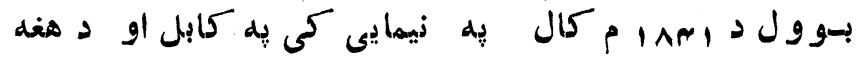

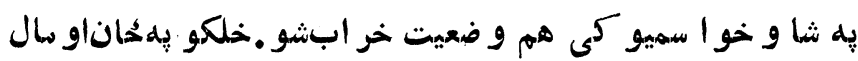

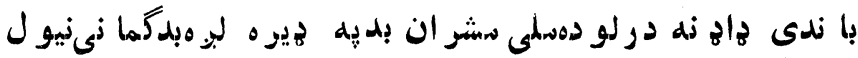

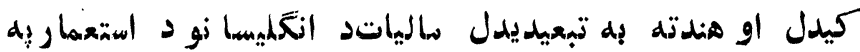

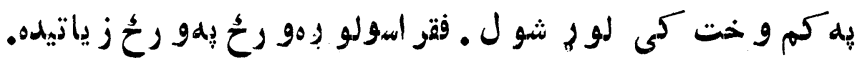

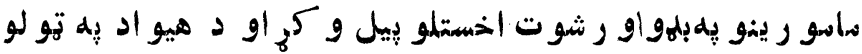
ساحو كى حالات ييجهلى كيد ل. سو هن لال د بونس سنشى جيى دجا

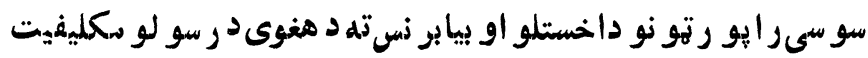

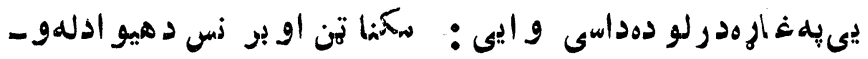
ضعيت خيخه بو ره خبو و و خو شتصى غر و ر همدارنكله ددويتر

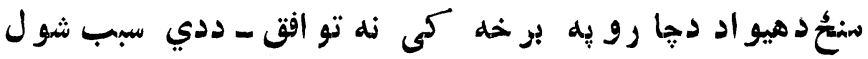

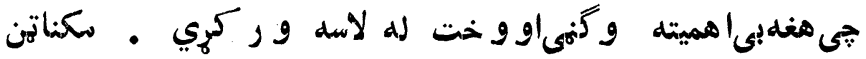

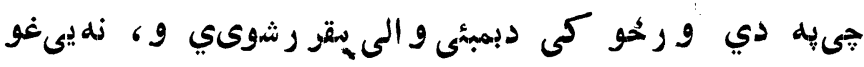

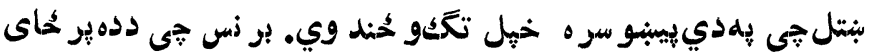
دخيلى مقو ريار زو لرله زهيى غو نبتل جیى تو خهلى سقر رى بو ري خdاقدام و كري • ( ه ه : ) )

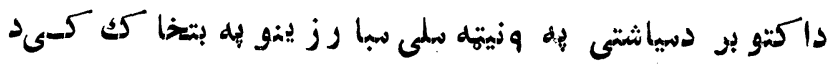

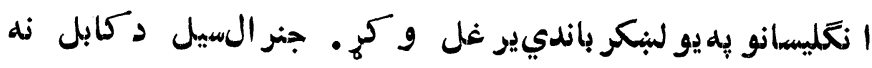
دسبارز ينو ددفع كولو دياره هغه خو اته و لأر پهه لارو كى دد

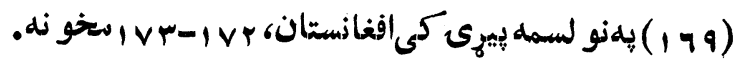




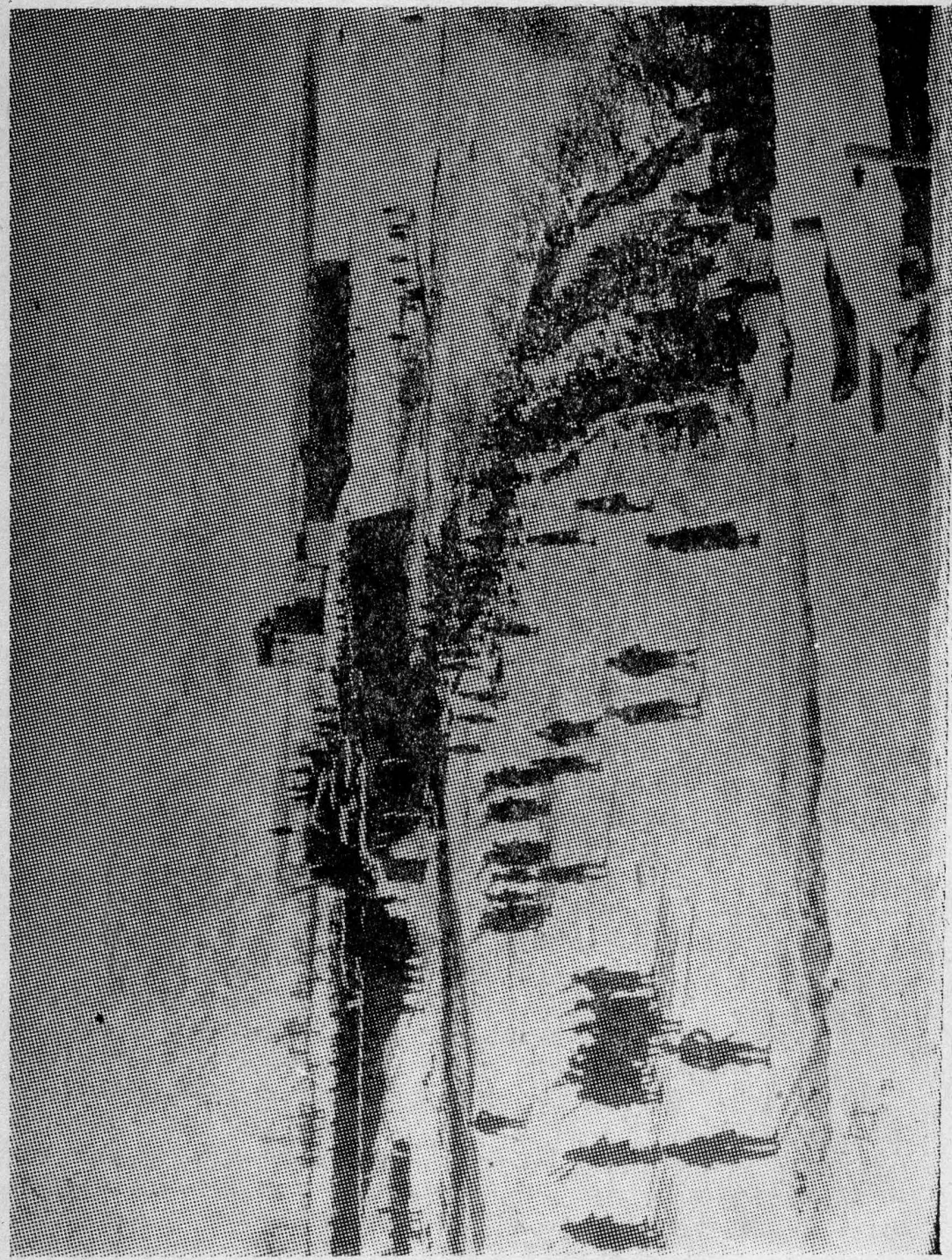

1 


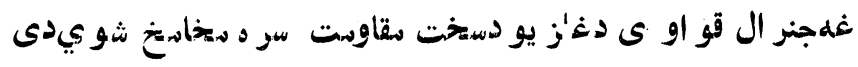

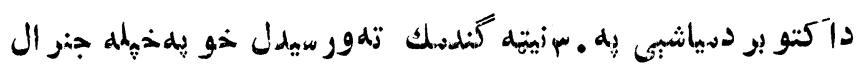

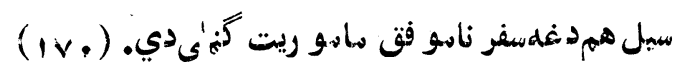

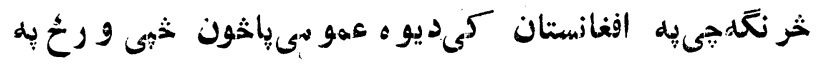

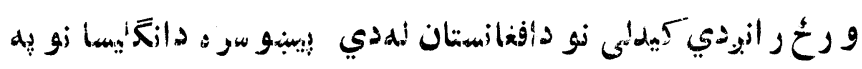

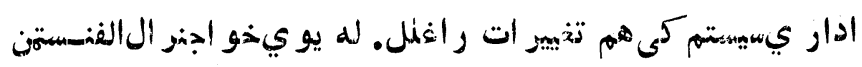

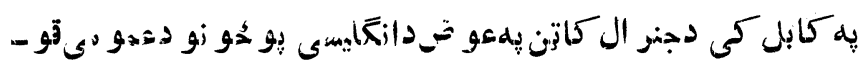

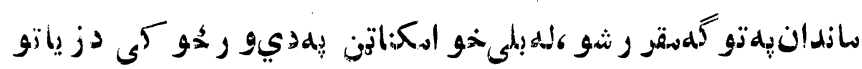

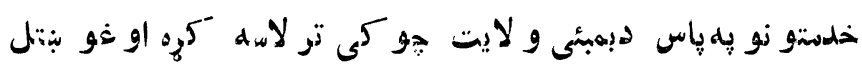

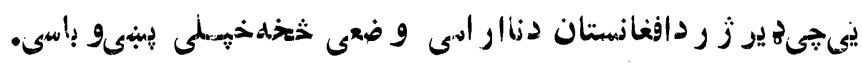

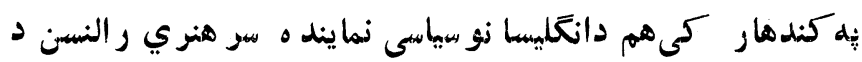

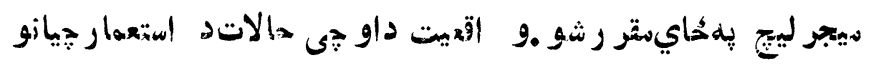

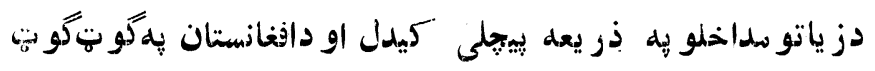

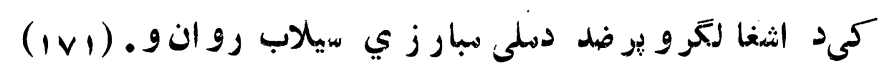

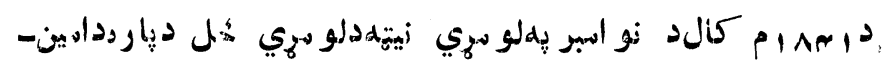

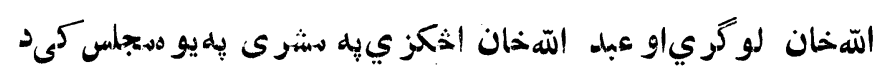

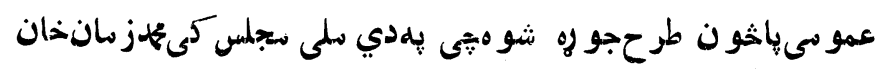

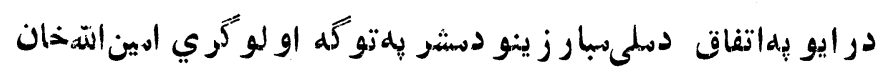

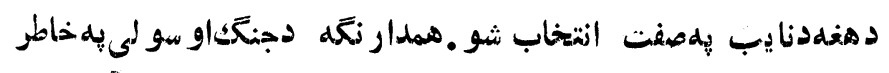

1-Louis Dupree, Afghanistan, P. 385. (IV.)

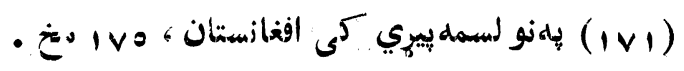


دو و لسي كميز هشو ر اتشكيل شوه هيد هغنه ادار هاو مركز يت.د

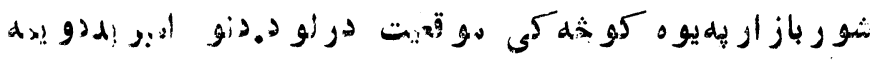

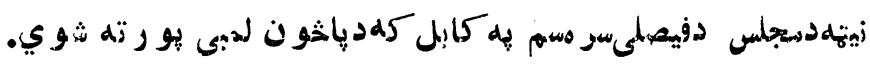

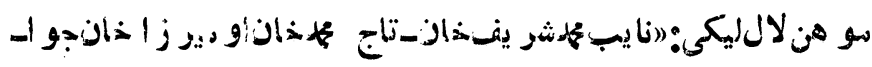

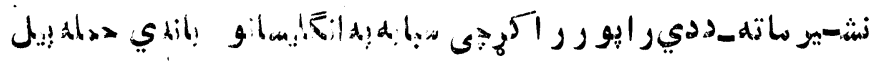

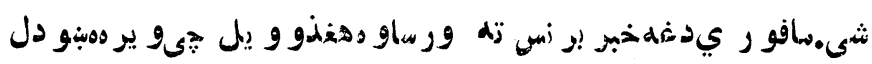

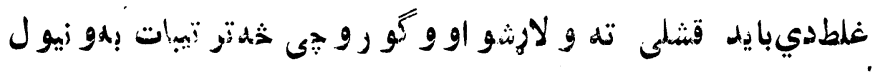

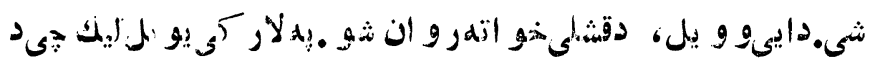

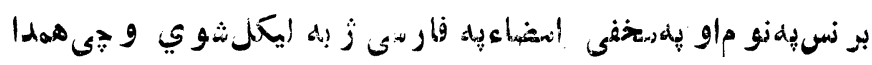

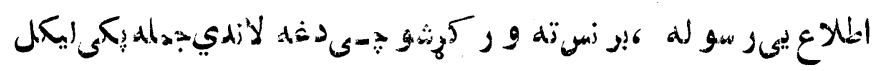

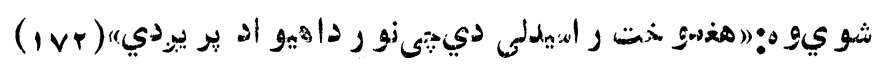

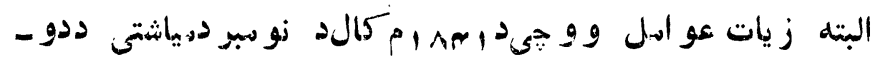

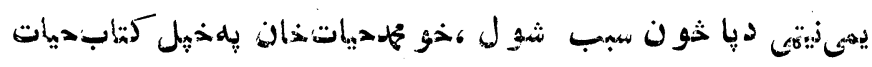

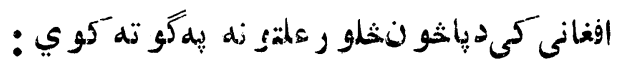

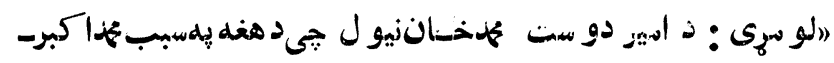

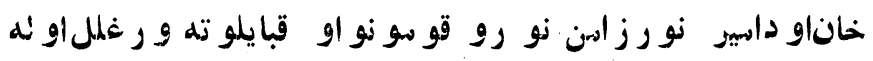

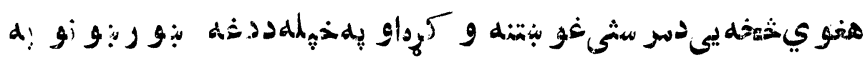
سز كىو دور يد ل .

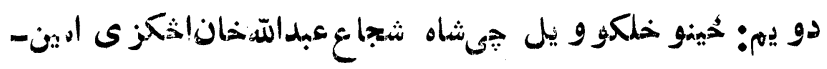

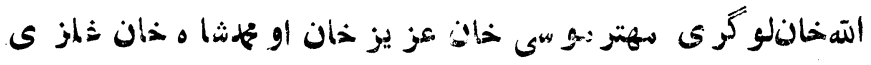

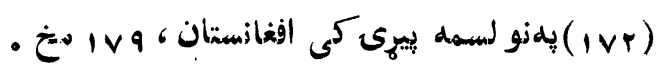




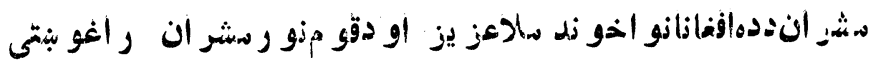

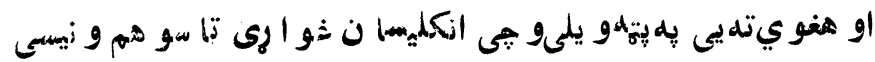

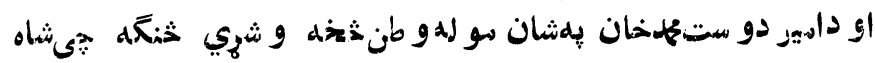

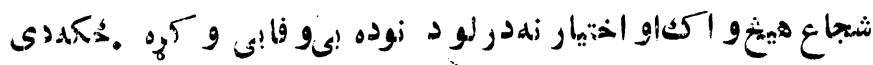

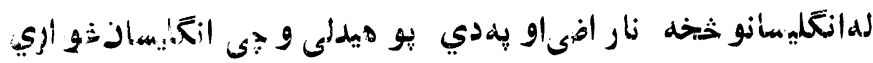

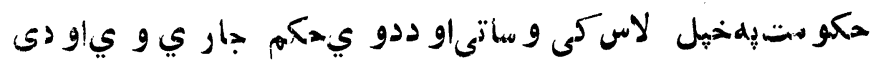
يو از يتثش يلنو م ياجٍاو ي .

در يم : حينو خو دنغ ضو خلكو د الدي تباليغ كاو هجيى ازخايسانو

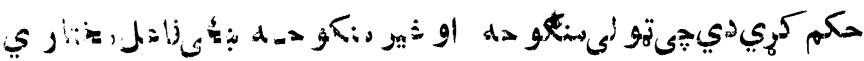

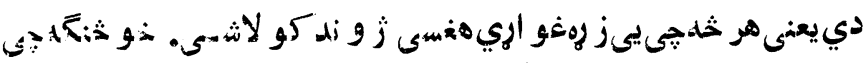

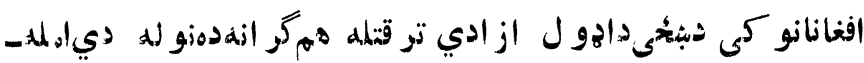

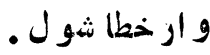

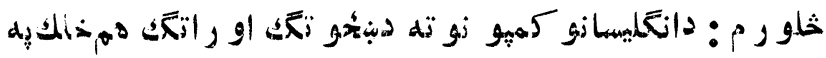

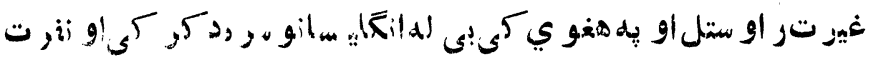
احسهاسر او يار اوه " • ( Ivr)

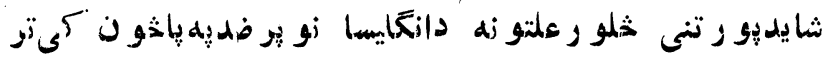

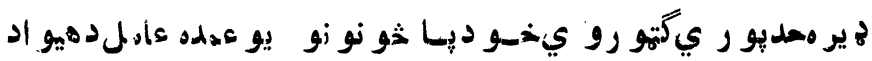
اقتصادي بنيهو هخكمانكليسانو يهديو خت كمى ير خلكو بانديلويز ساليات

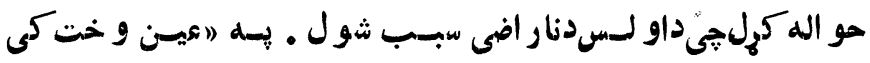

• d حيات|فغانى، ه ( IVr) 


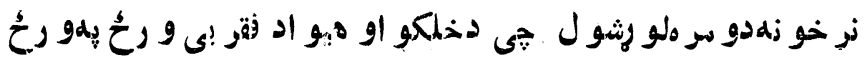

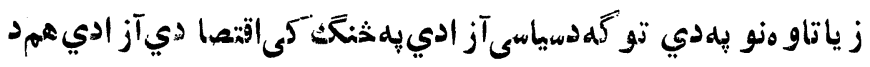

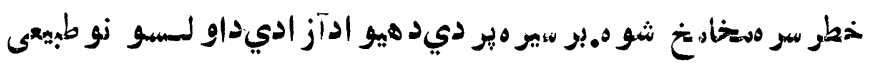

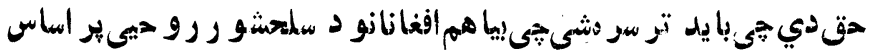

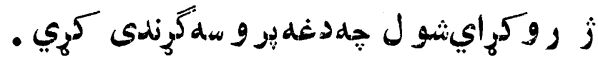

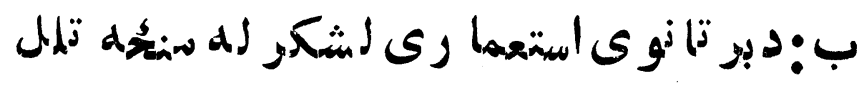

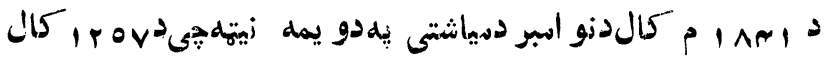

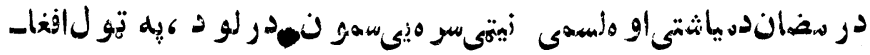

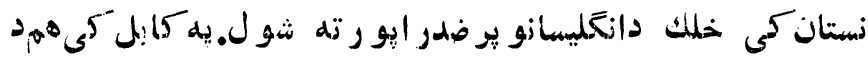

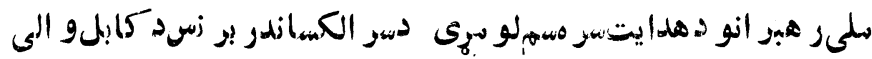

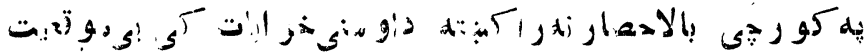

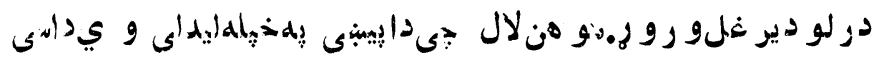

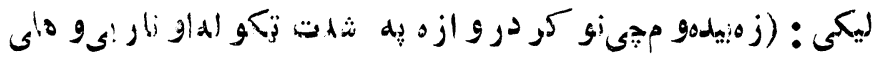

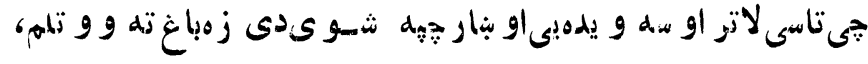

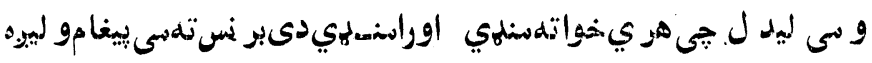

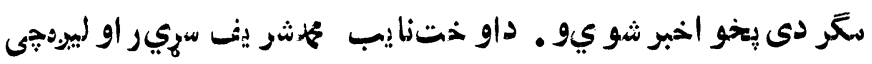

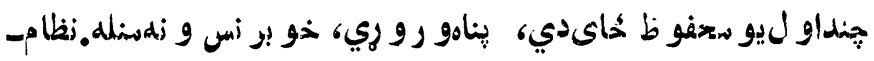

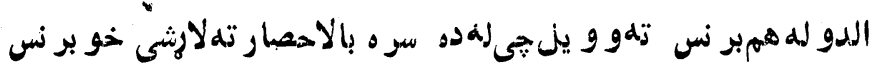

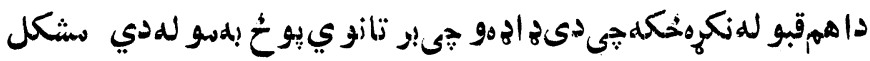




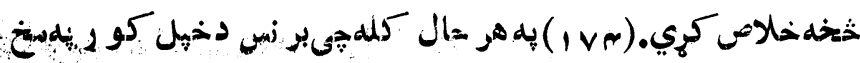

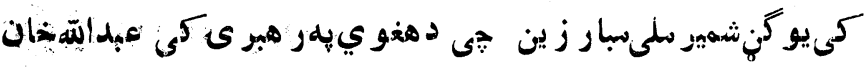

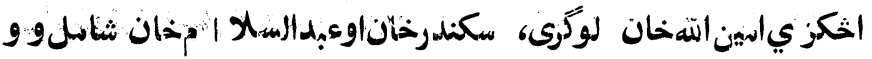

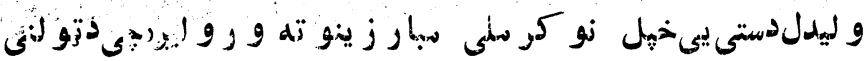

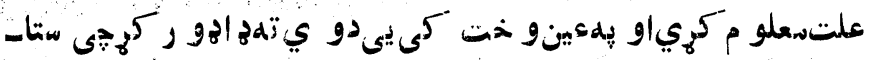

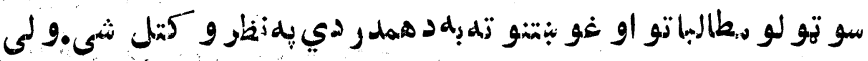

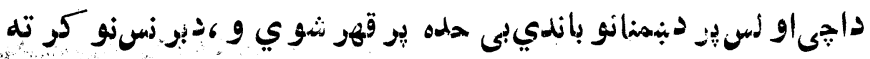

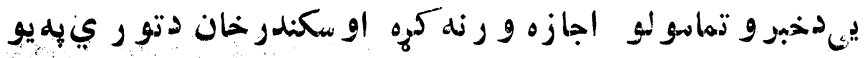

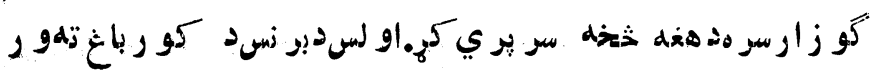

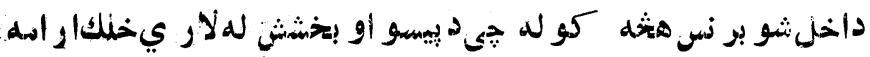

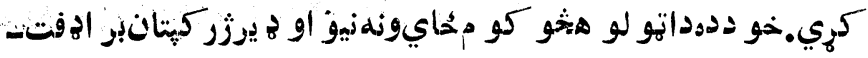

- Charles Burnes. - جأرلس بونس -Capt Broad foot. -

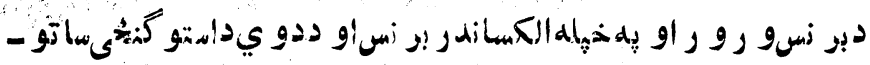

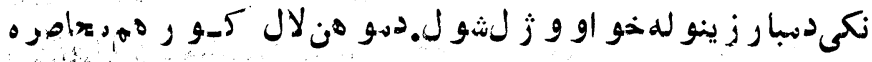

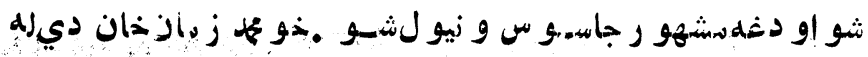

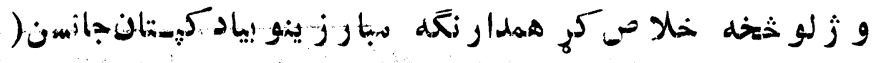
Capt - Johnson.

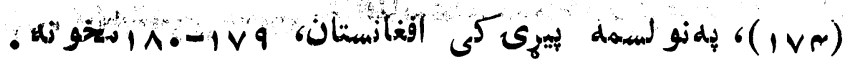


الفانانو بهنغ كى يىدنلاق او از ادي دروع و وز لودياره ذخيره

$$
\text { (ivo). }
$$

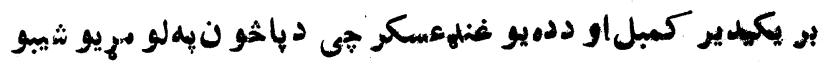

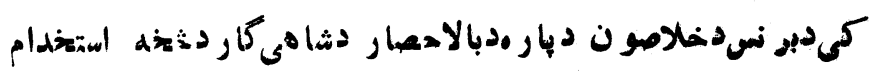

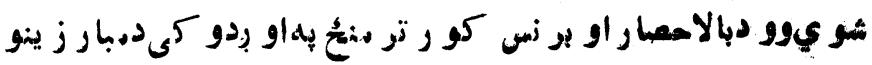
لهخو اتباهشول او دهنو يو سلهد مبار ز ينو بهلاس كيى بر يو يو ته.

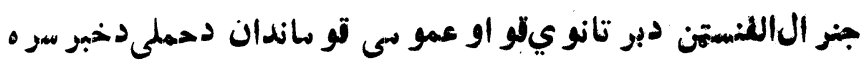

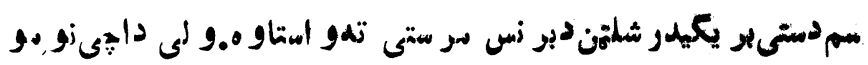

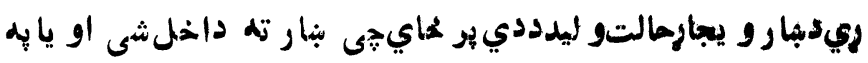

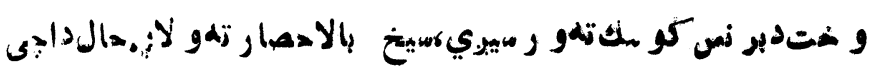

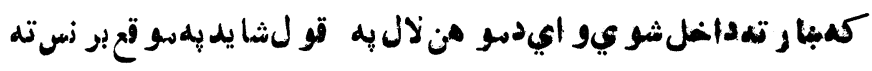

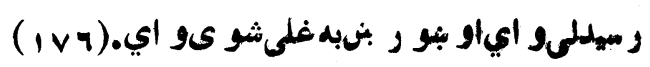

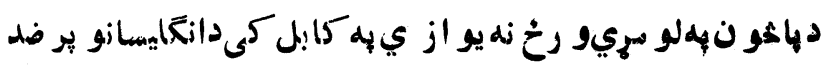

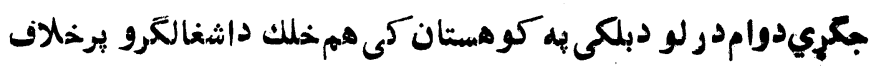

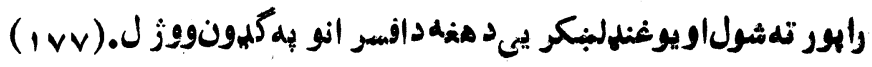

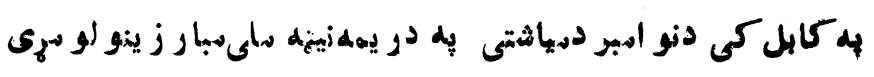

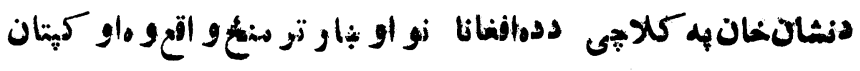

.

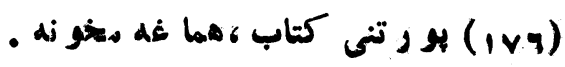
(IVV) . $-1 r m-$ 


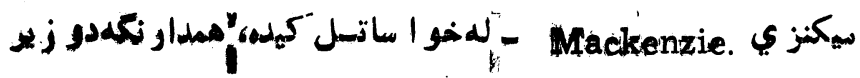

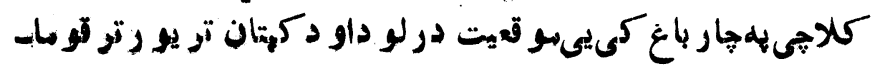

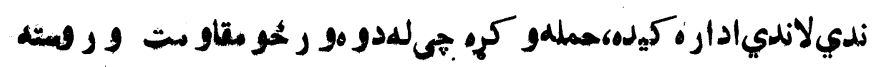

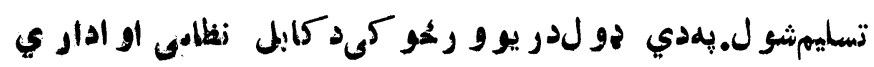

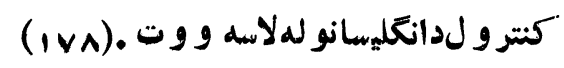

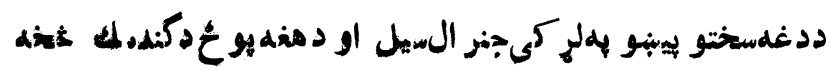
ر اوغو بنتل شو-به خو رد كابل كى انكليس لنهكر هم مركز ته راغى

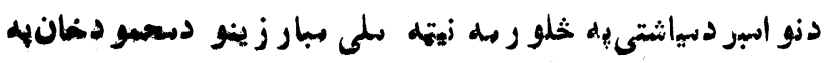

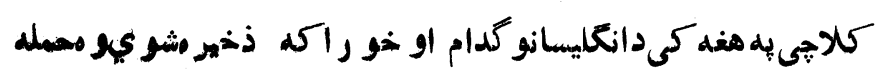

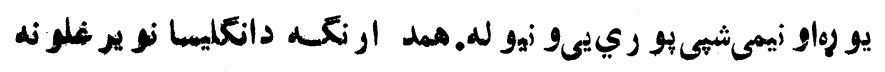

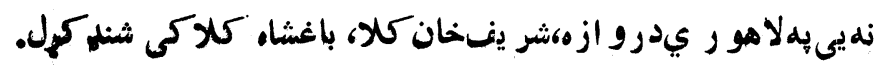

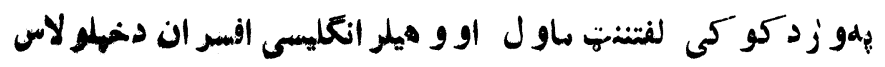

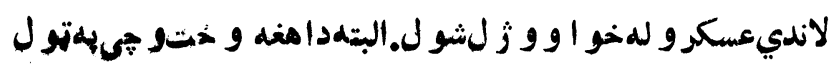

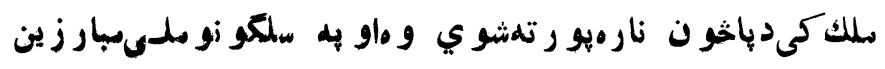

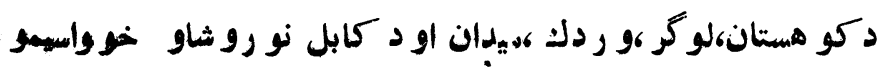

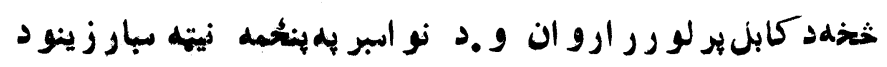

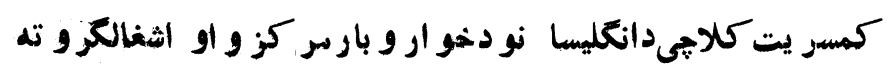

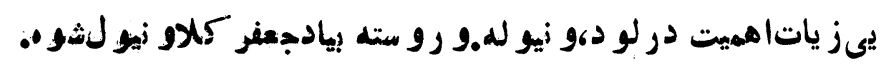

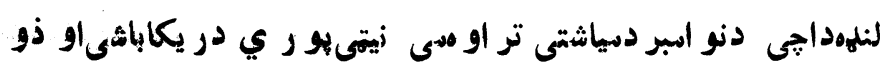

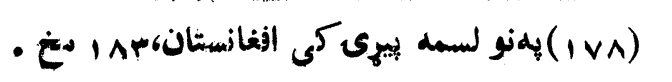




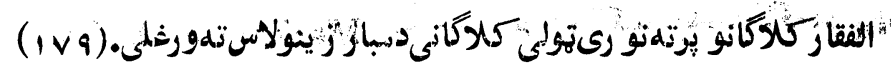

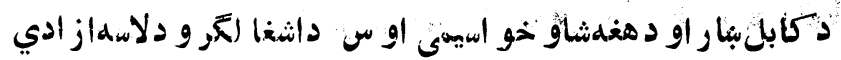

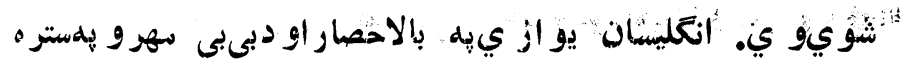

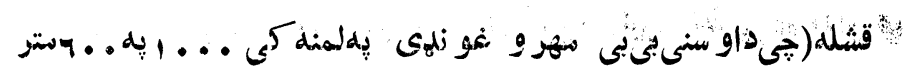

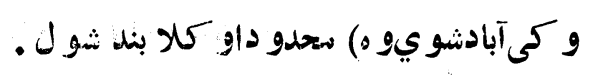

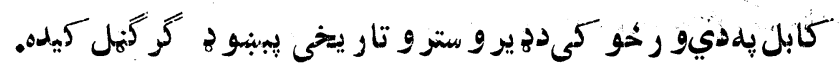

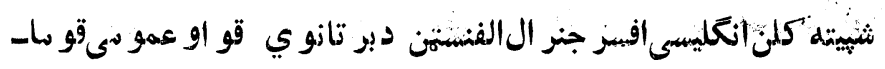

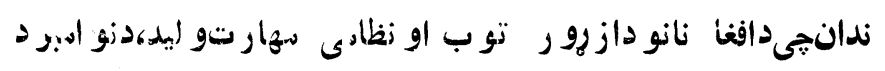

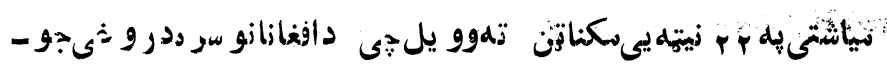

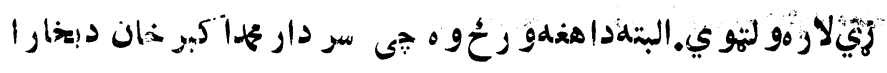

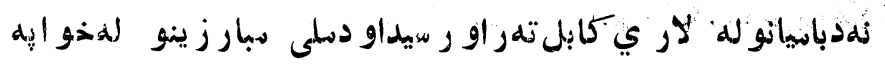

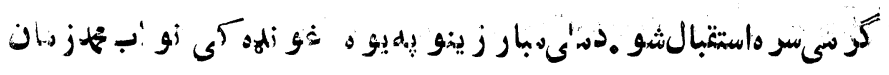

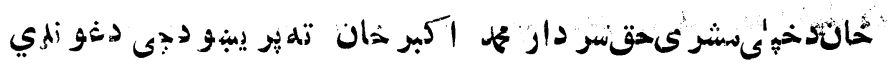

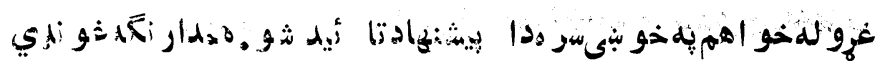

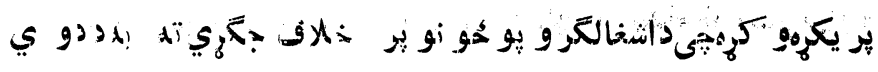

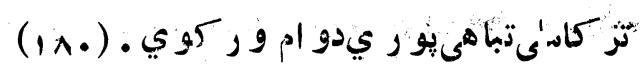

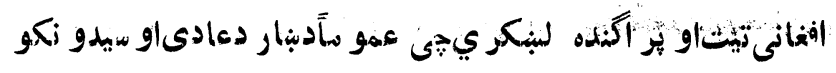

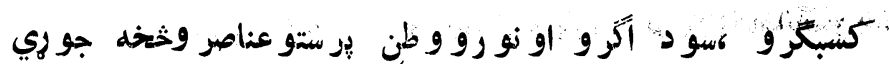

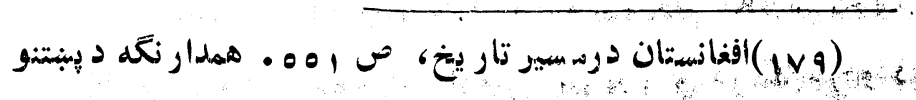

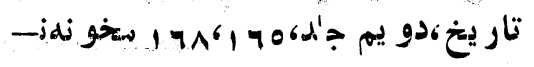

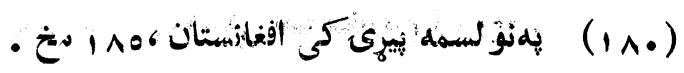

$$
\text { - ita - }
$$









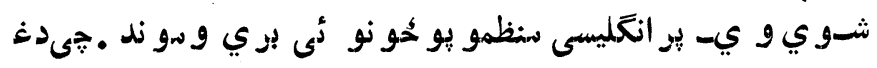

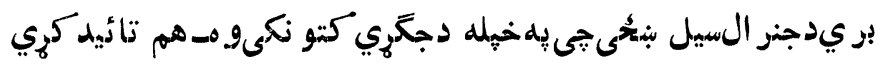

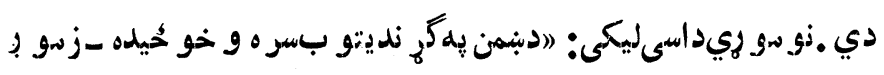

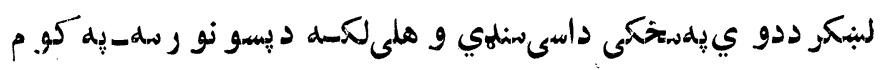

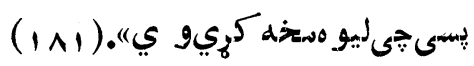

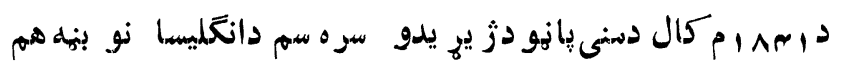

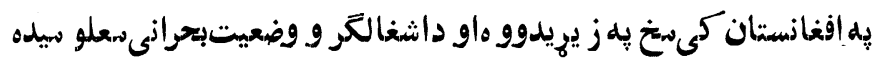

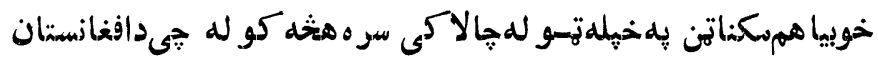
و ضعه نِيسيسو -رشو ت_نفاقاو ترو رلهللار ىسمهاو عادي كاندي.

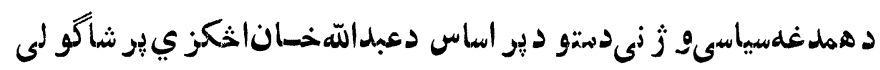

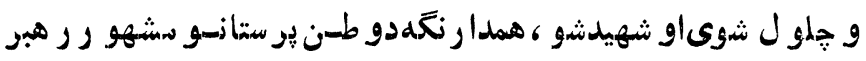

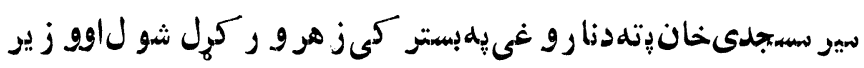

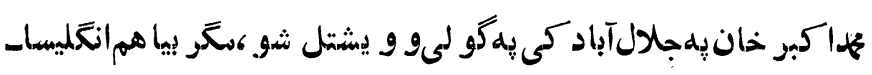

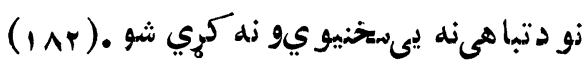

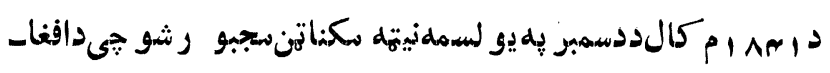

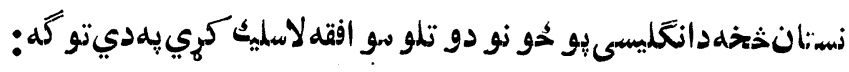

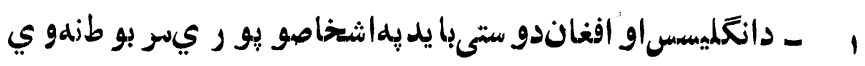

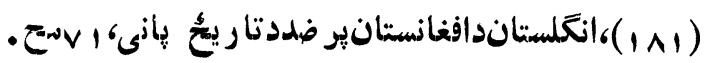

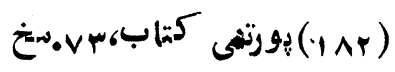

- ITV - 
لكهششاه شجاع جى دازكَلمسياذو دو ست او دافغانانو دبنبمندي-بلكىبا يد

$$
\text { دو لتىو ي . }
$$

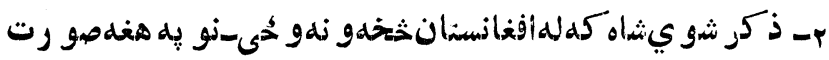

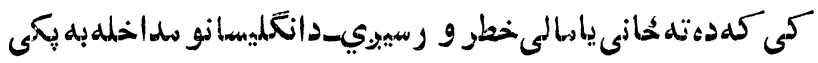

- زلم

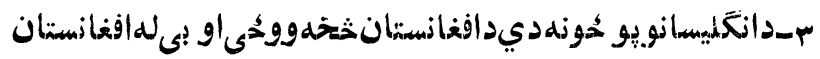
دحكو متلفخو اهشنه دي جيى هغلبه همد بر دي دبنمن ددفع كولو ديارووي - بيا افغانستان تهر انهشىاويه هغdصورت كىيى همبايد

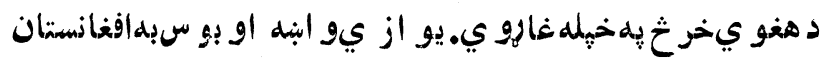
دنقدو بيسمو يه بدل كمى و ركوي .

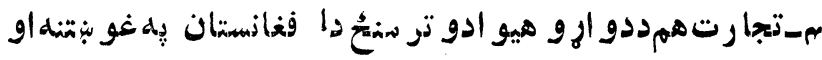

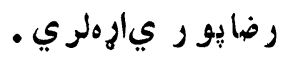

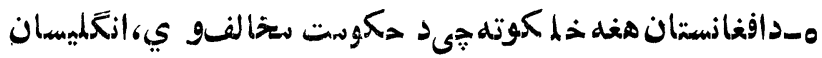
با يد هندته دداخليدو اجاز مور نه كري ـ همدا رنكانهعاشديور تهنه

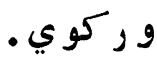

ه- كلنز ار ير و ساو يانو رهيو ادو نه دافغانستان لهلار ي يه

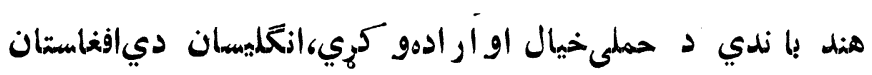

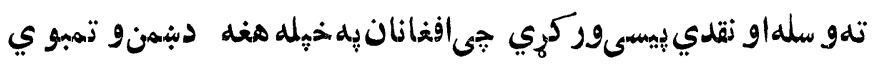

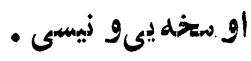




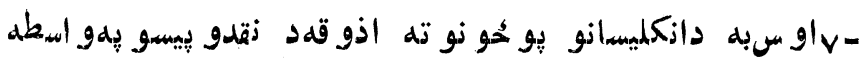

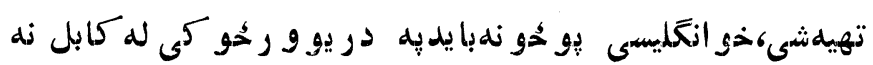

$$
\text { و و }
$$

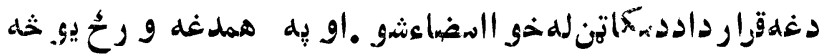

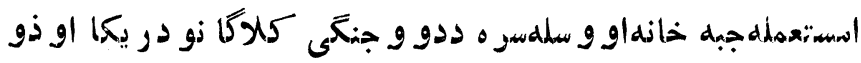

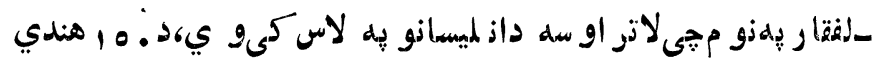

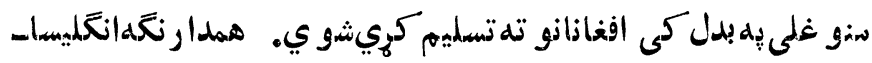

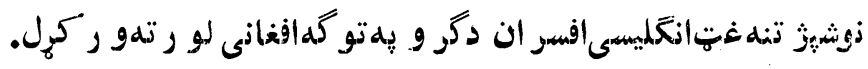

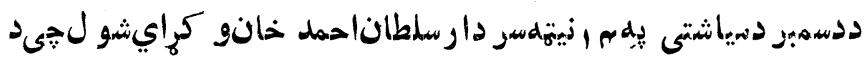

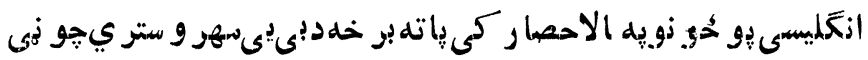

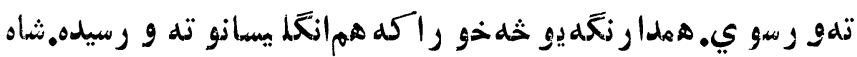

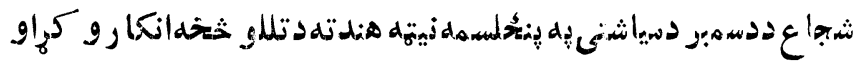

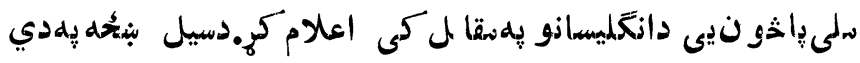
بو خه كى داسى ايى (اثشاهشجاع نه يو از ي انكليسما نو سو ههندتهتخك

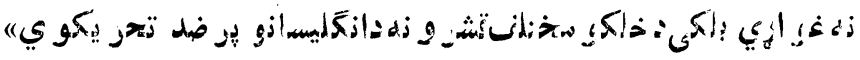

$$
(\operatorname{l\wedge c})
$$

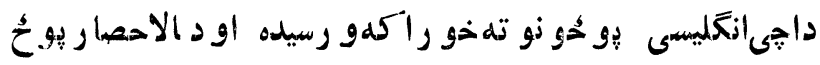

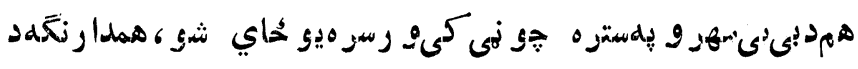

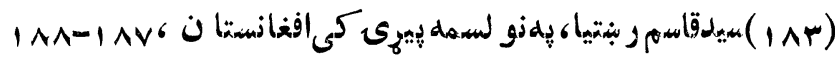

$$
\begin{aligned}
& \text { ن نيو نه }
\end{aligned}
$$

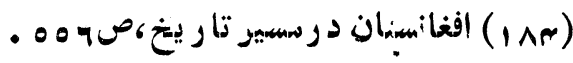

$$
\begin{aligned}
& -1149-
\end{aligned}
$$




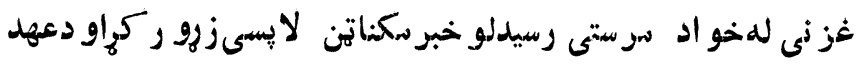

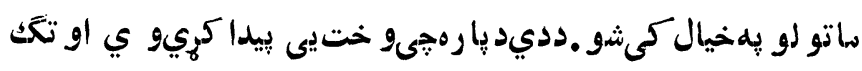

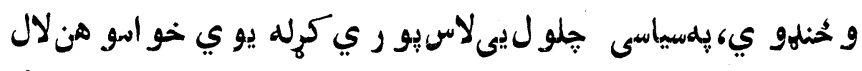

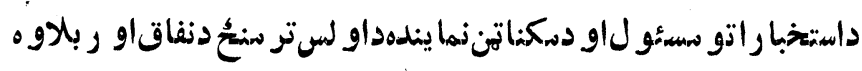

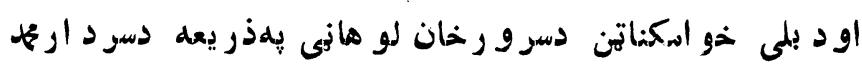

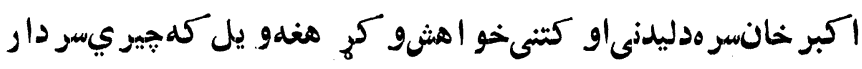
و غو اري و زارتـ حتىد افغانسينان سلطنت بلهو ر ته و ركرئى •

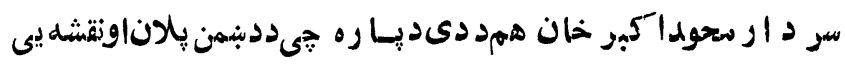

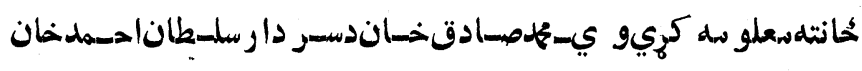

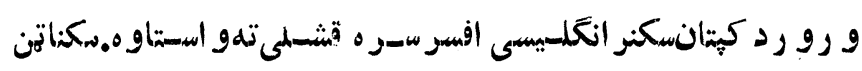

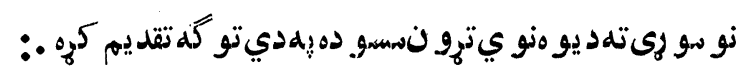

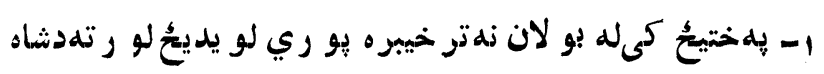

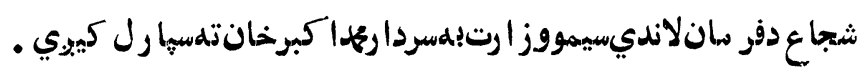

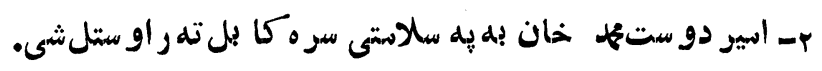

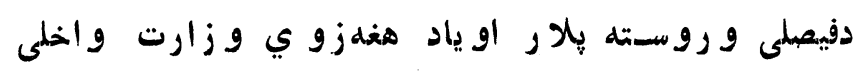

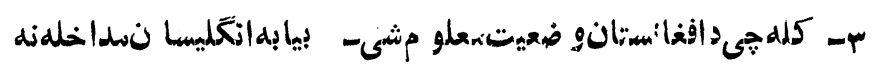
كو ي.

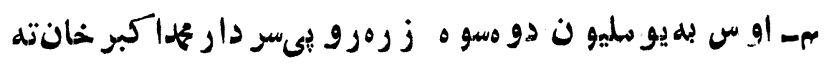

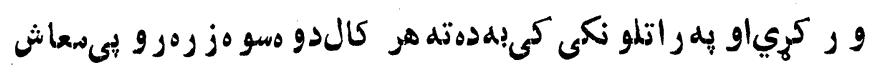
و ركول كييوي . 
هـ او لسديمها كبر خان او نايب السينالهخان لوكريو نيسىاو

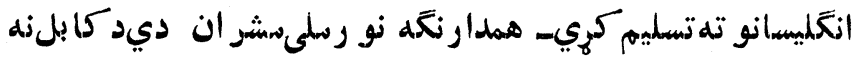

$$
\text { خو اروبو اره كريشى. (110) }
$$

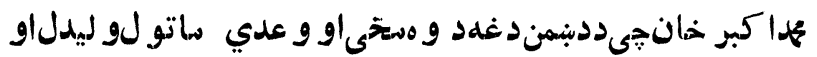

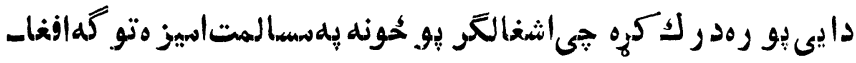

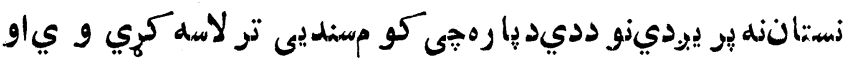

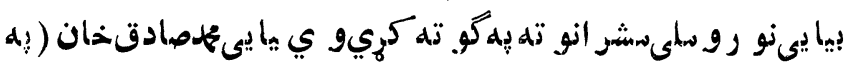

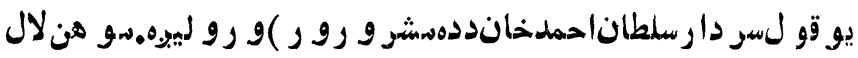

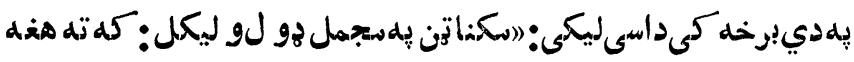

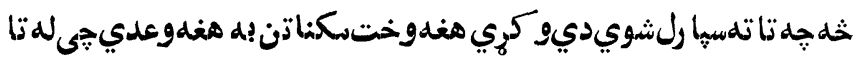

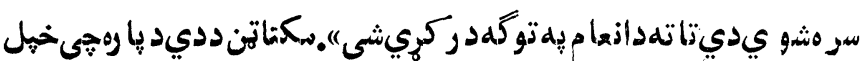

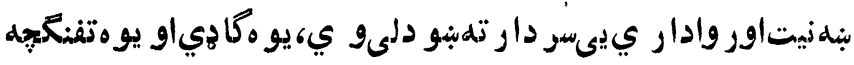

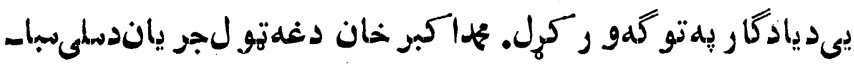

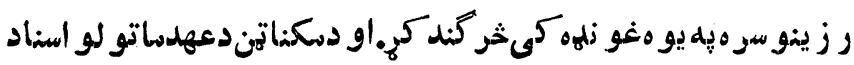

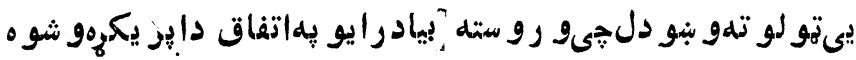

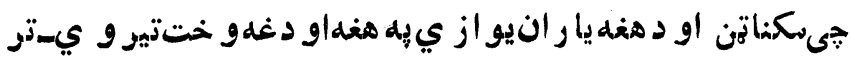
خو جىدجلال آداو غز نىنهو رتهسو سته ر او ر سييوياو سمر ?يوهيو -

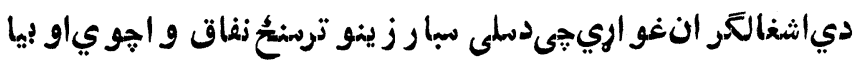

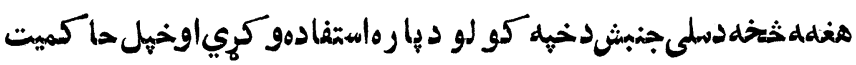

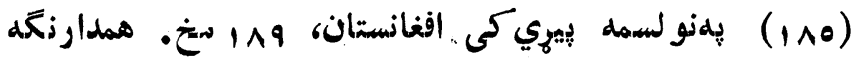

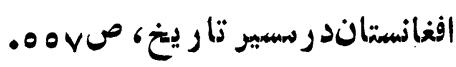




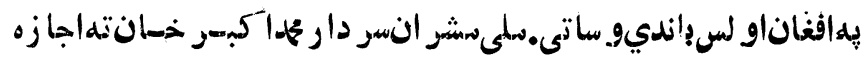

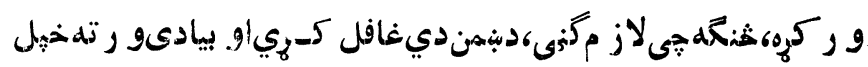

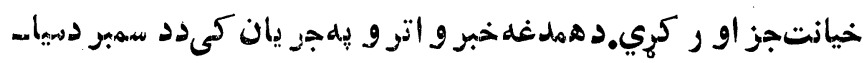

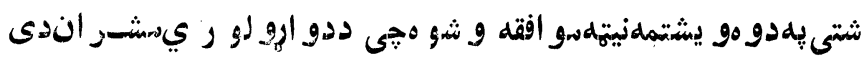

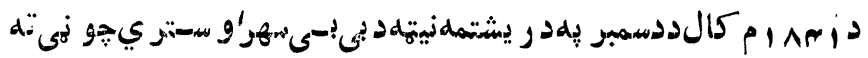

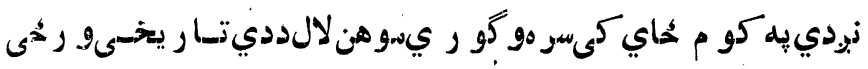

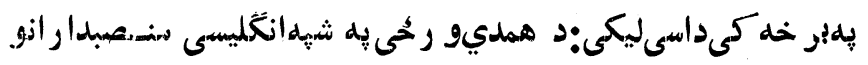

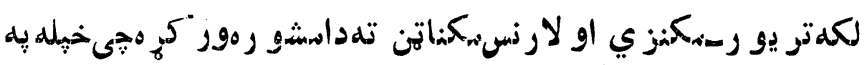

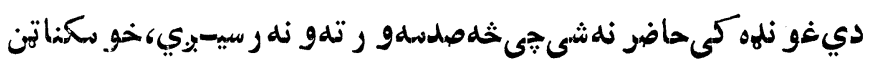

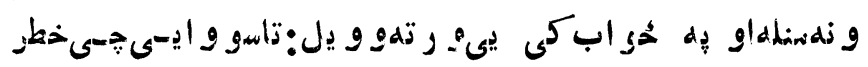

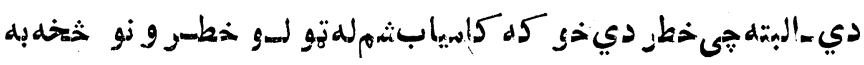

$$
\text { نجات يֶيداكيو . (1197) }
$$

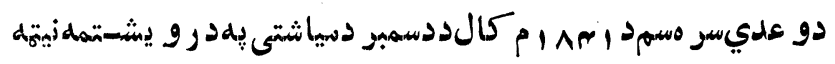

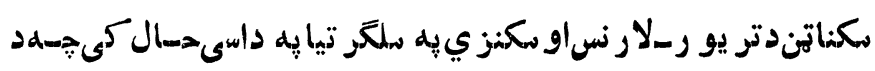
ازخَليسانو دوه كنله كهيلى

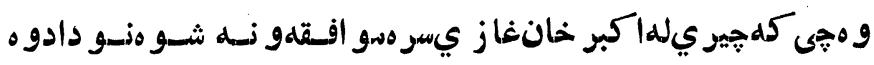

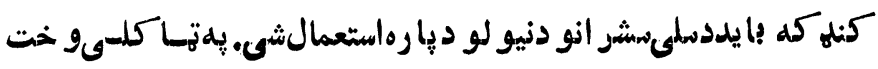

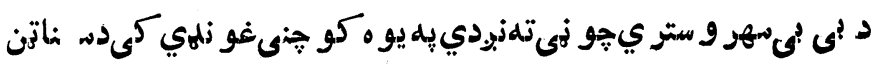

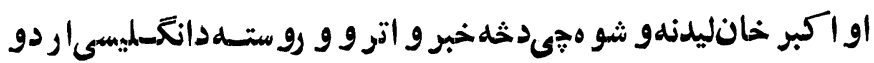

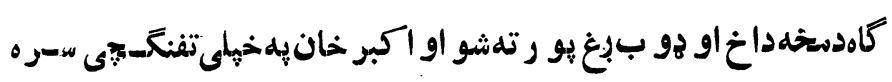




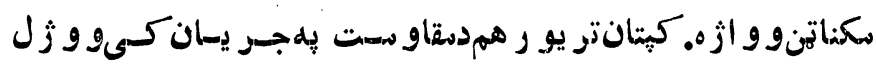

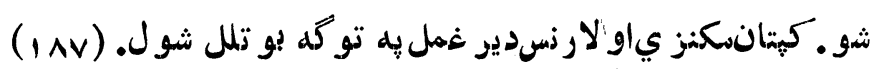

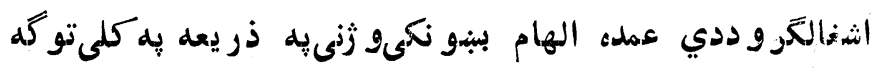

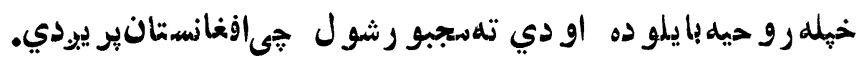

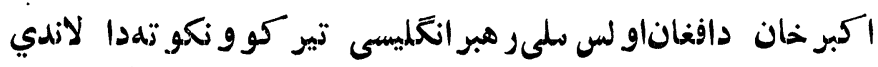

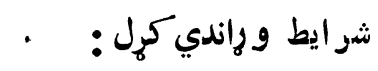

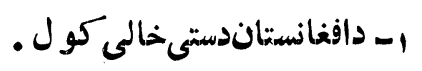

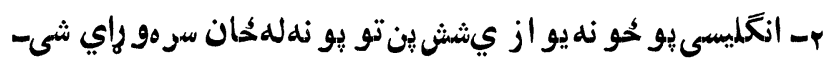

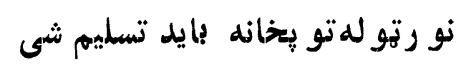

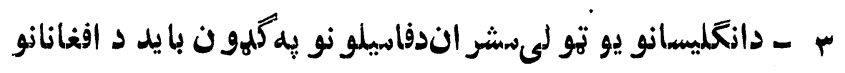

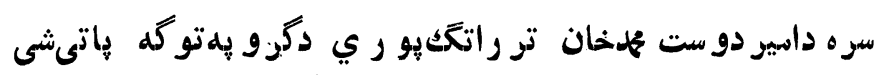

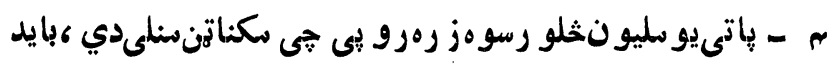
افغانانو تهور كريشى . •ـ جبه خانهاو نو ر هغلسانتانجيدر انهو ي ـافغانانو ته دي تسليم

$$
\text { كري.) (1/1) }
$$

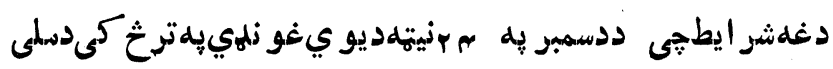
دِاخو ن دشو راد غزول لهخو اتصو يب شول ،دستى به كا بل كىد

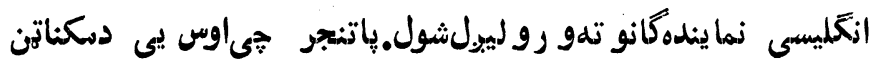

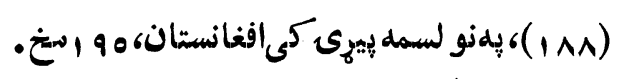




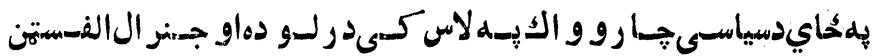
د إو تانو يقو او عمو سىقو ماندانذستىيو ه زظاسى غو نله تشككبيل كره او دافغانانو دغه و راندي شر ايط دتىو سنلشو. ل.اوجسنر الالفنسن

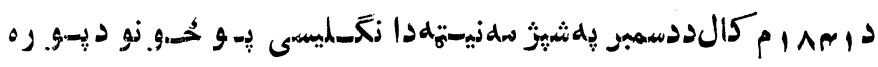

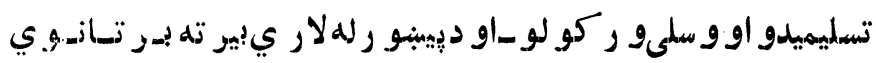

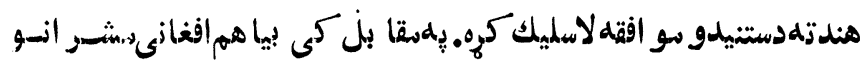

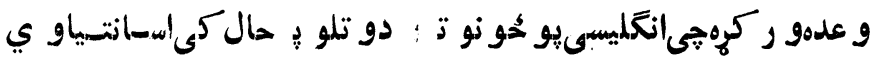
بر ابرو ي او دلارو بهاو بِدو كى بهددو ياسنيت تاسينو ي.دتسيوون

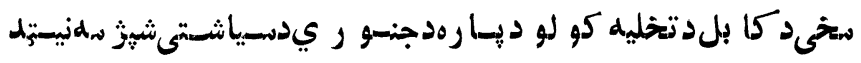

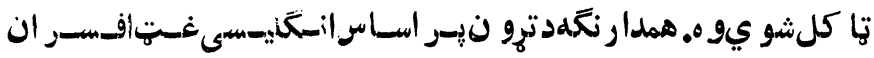

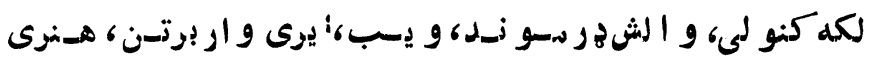

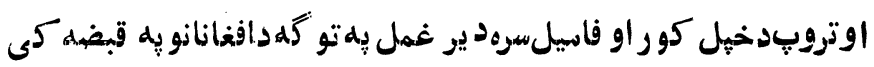

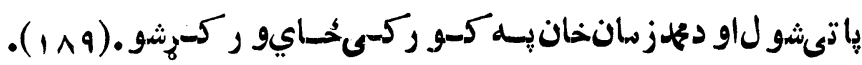

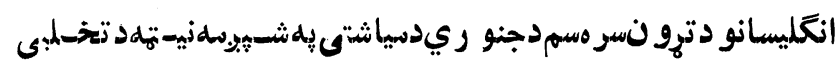

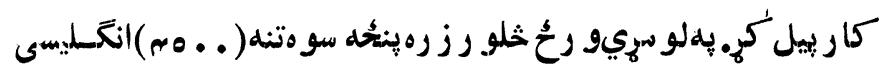

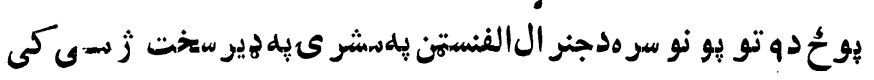

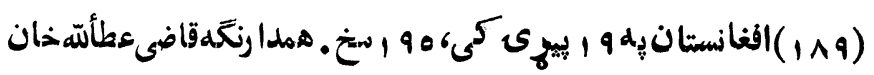

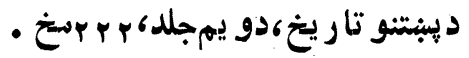




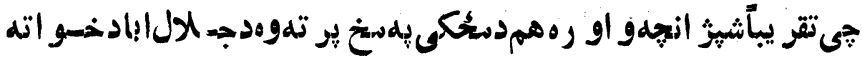

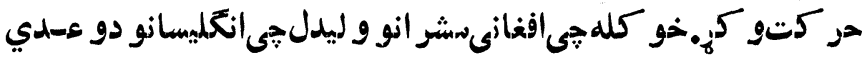

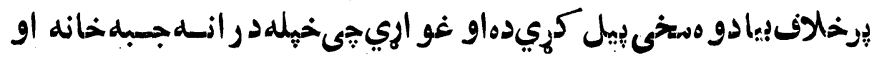
تو يو نللهُانسوه يو سيبنو لهدي كبلمسردار سملطاناحمدخان،

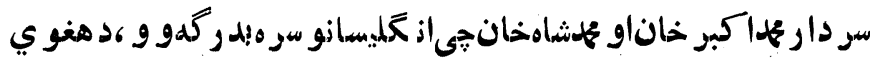
لd حهايت زلهلاس و اخيسهت او همد اوختو جيى سبار ز ينو او افغان

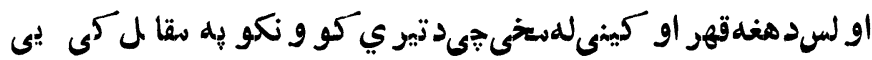

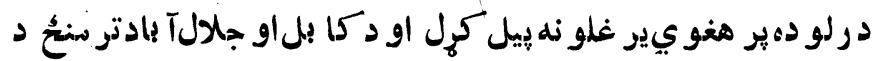

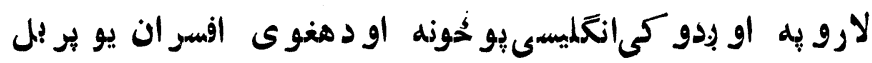

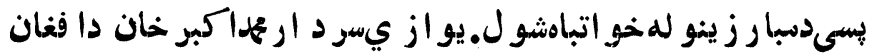

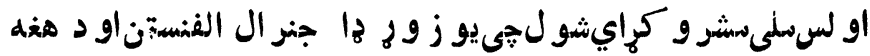
بنيكى او ساثو مان توخهلى ساتنى لاندى جلال آيادته سالموور سو يخو

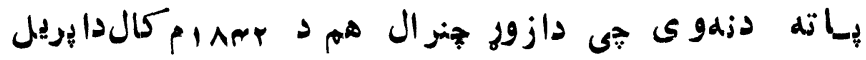

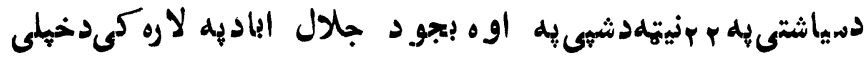

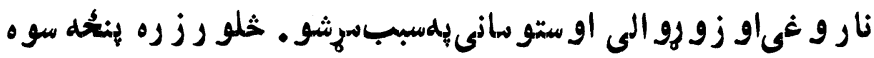

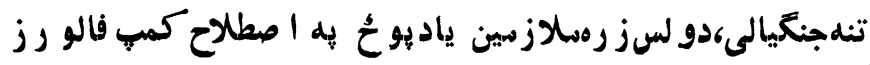

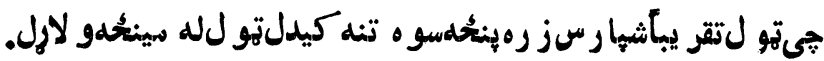
لهدي خخه يو بر ايدن هغd همستري ستو مانو بيداو شكيد لى كالى زو زوجلال

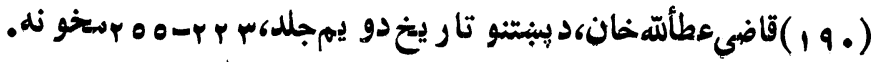




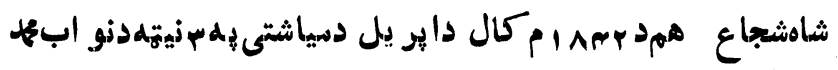

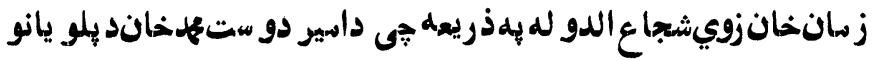

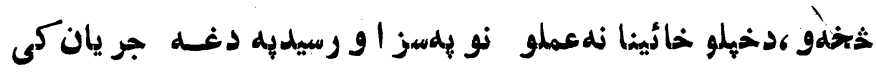

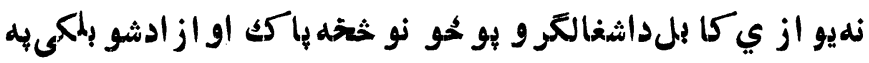

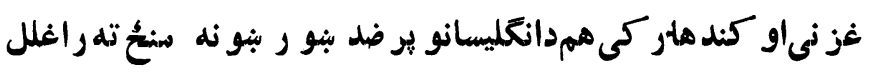

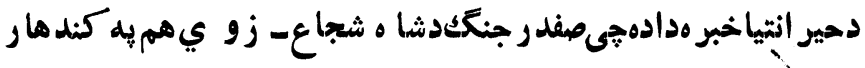

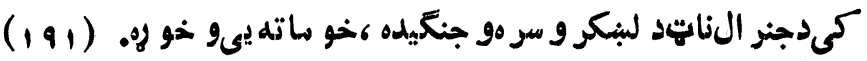

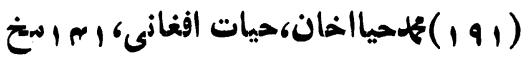

$-104=$ 


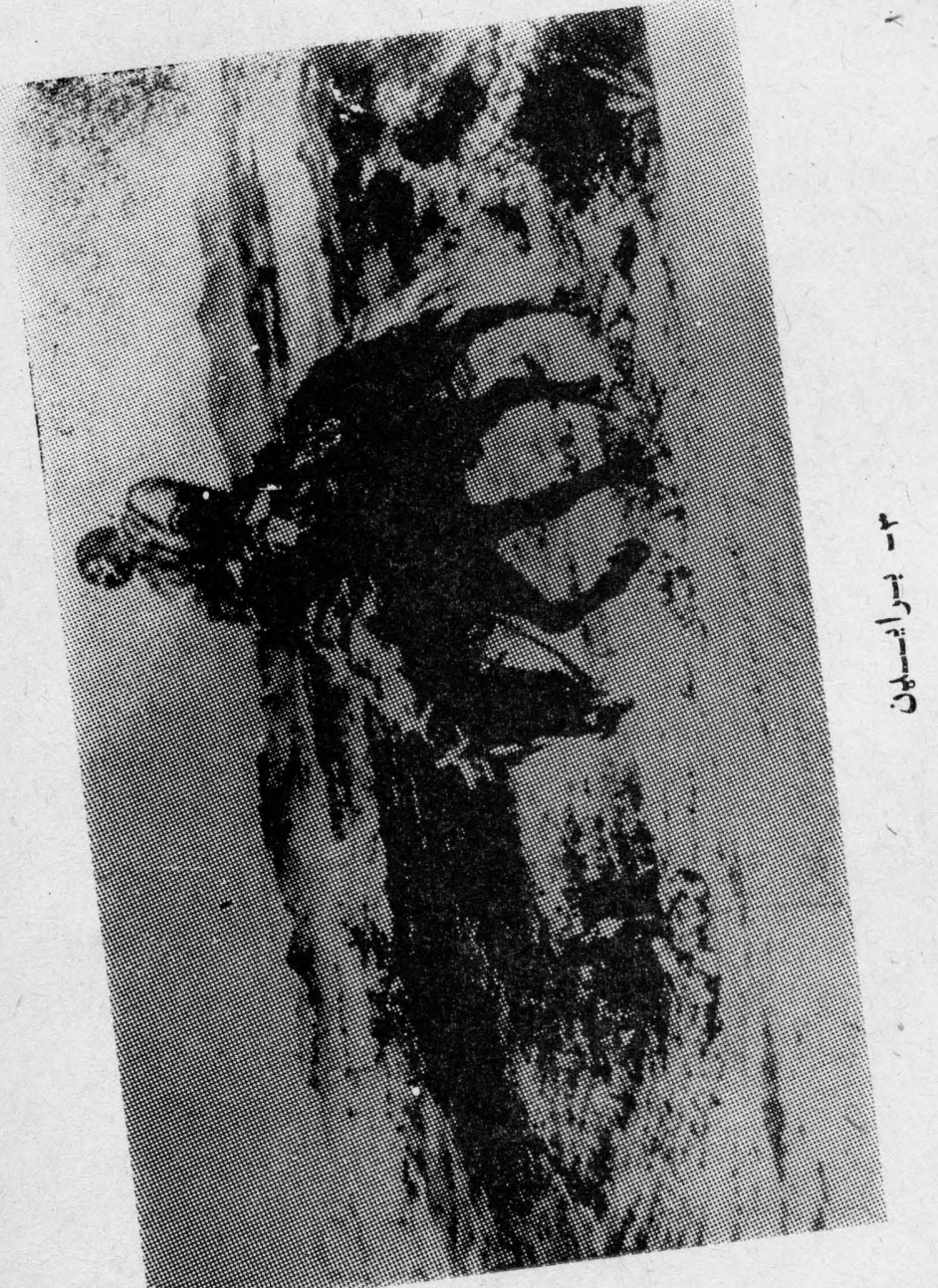




\section{اتمفصل}

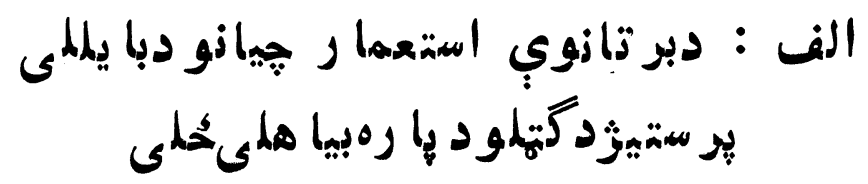

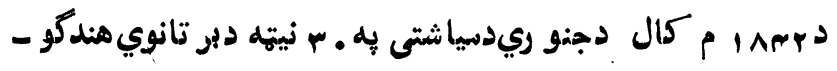

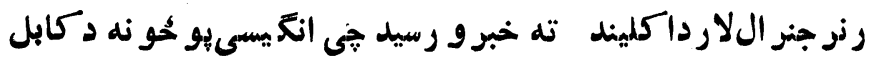

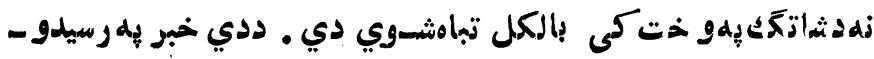

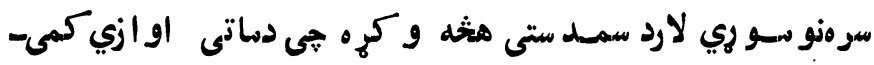

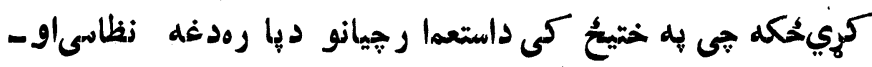

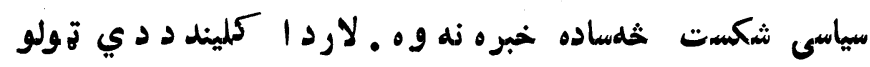

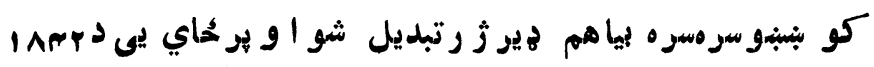

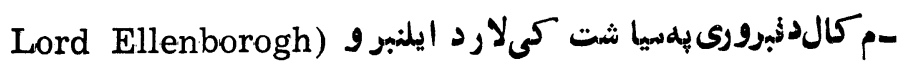

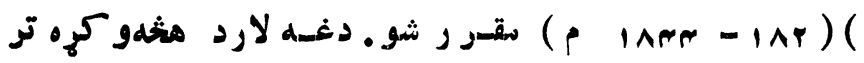

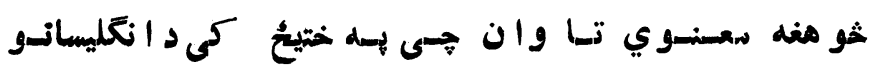

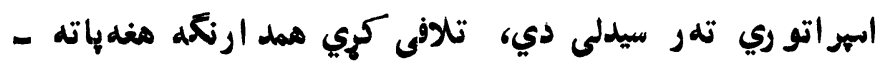

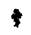$$
\text { - ier - }
$$ 
شوي يو حُونو ته جيى لاتر اوسه به افغانستا نكى به جكرهبوخت

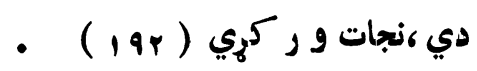

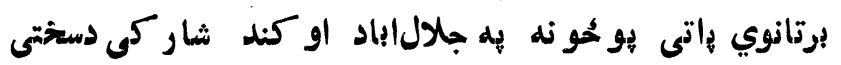

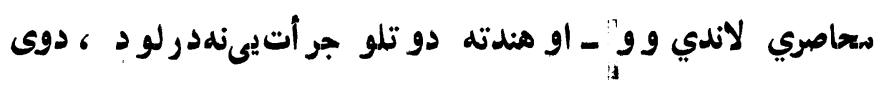
هار يدل جه بر دوى بانديبه هم د تللو به حال كمى دكأبل دانكليس بوحمونو كانه و شئ. دوست ديحمد خان جِى لاتر اوشه دتبعيديهحال شبى سباكو لى

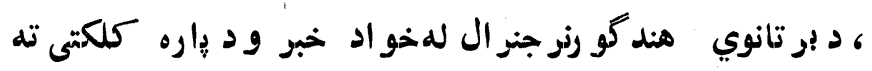

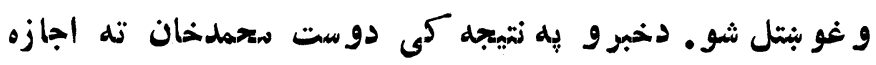

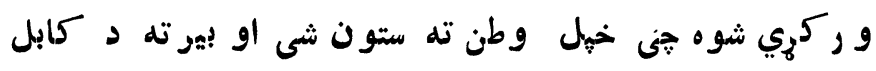

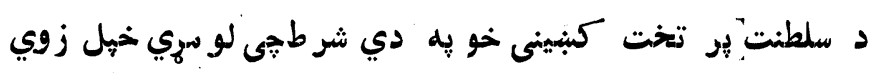

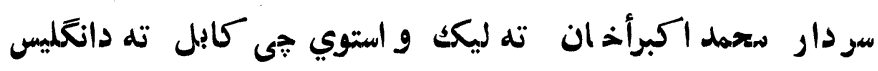

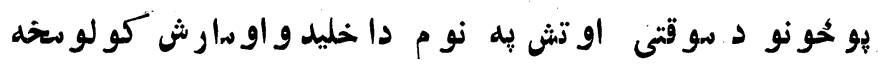

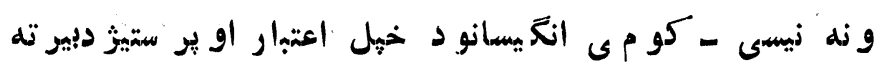

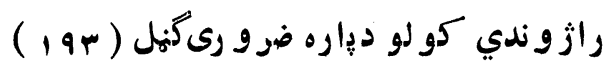

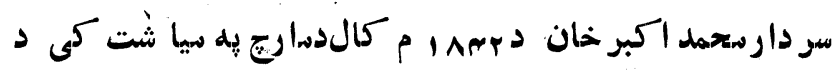

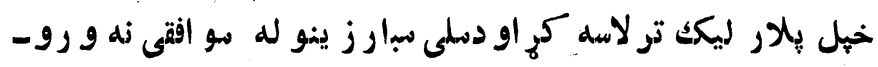
-

$$
\text { • va - VA }
$$

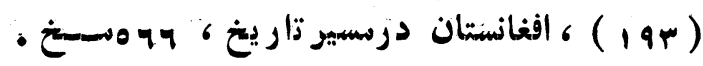

$$
\text { - IrA - }
$$




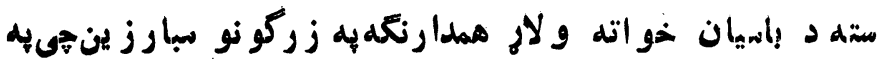

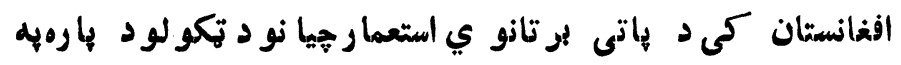

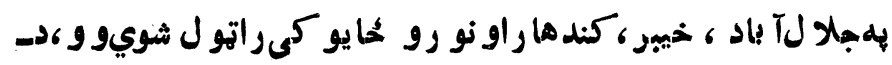

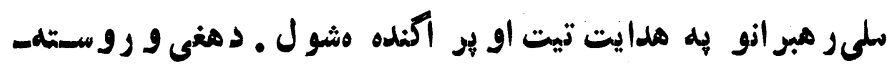

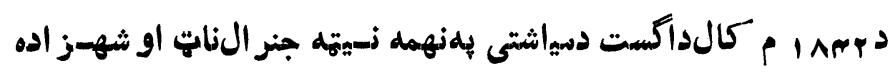

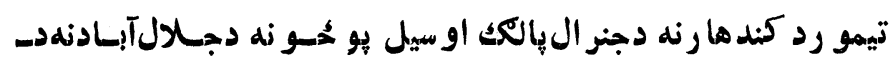

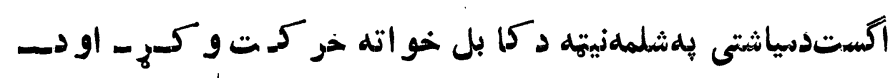

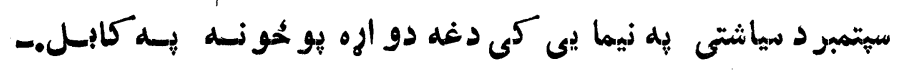

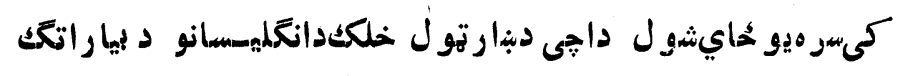

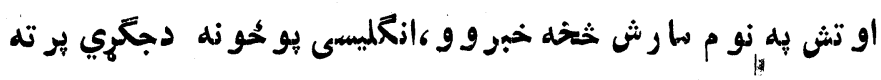

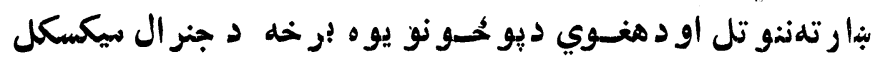

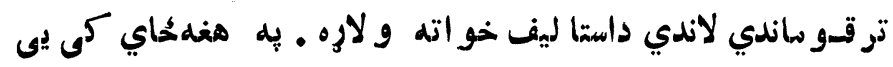

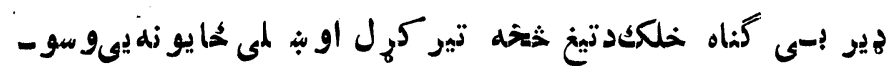

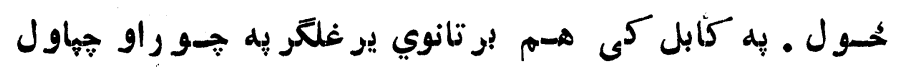

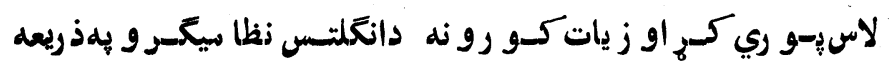

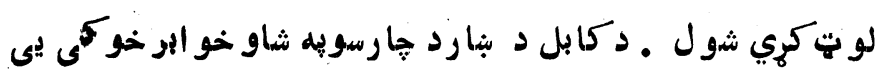

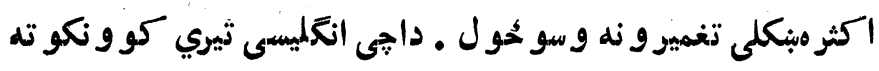

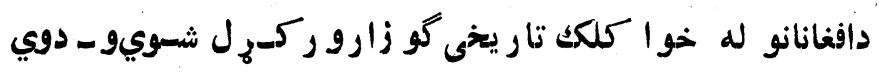

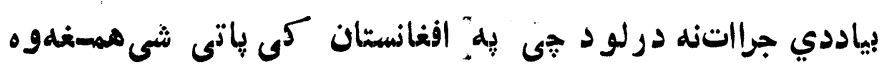

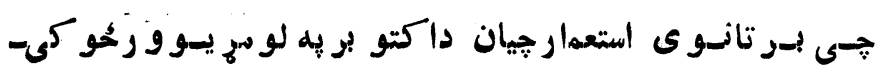
دجلال آاد خواته ولارل اوداكتو بو د دياشتى به بمى نيته جلال 
آادته و رسيدل ـ يو و و ركُو رو سته بيد جلال آباد بنار وسو محاوه

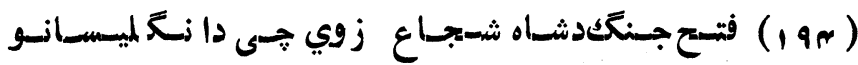

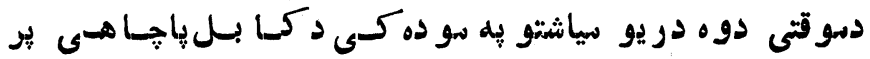

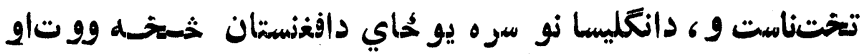

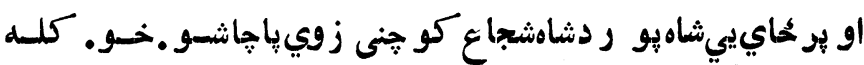

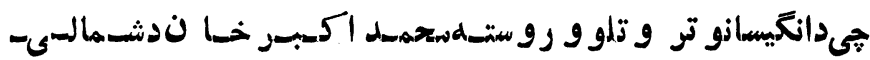

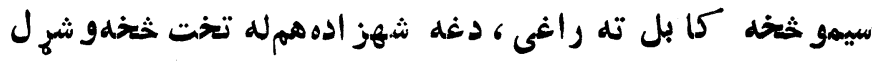

$$
\text { شسو (190) . (190) }
$$

ف انتللس هم بها خيل اثركىدبر تانوىاستعسمار جهيانسو دهغسه

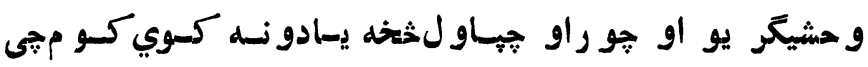

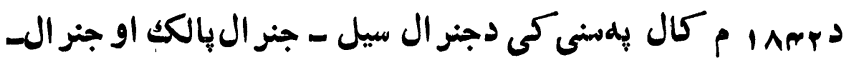

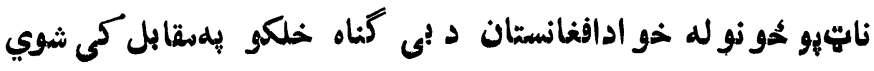

$$
\text { دي . (199 ) }
$$

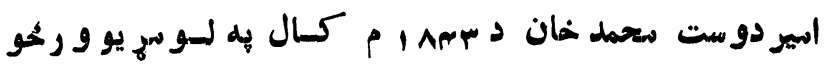

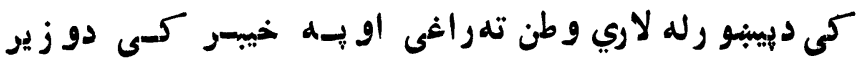

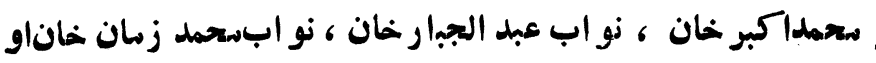

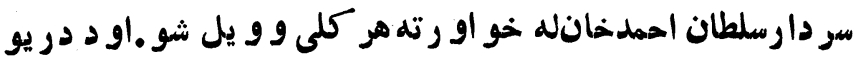

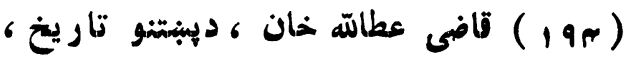

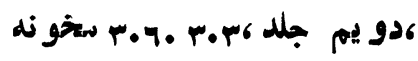

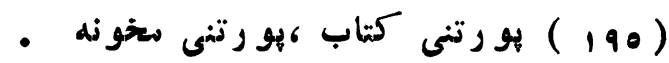

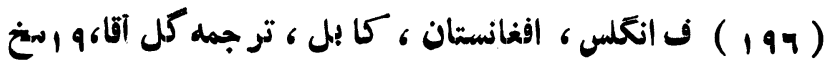


كالو او وخلو رو سياشتو و وو سته يى بياد افغانستا ن دهارو

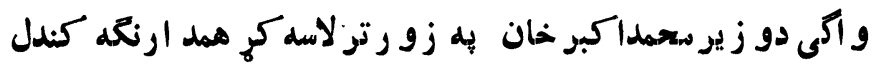
خاناو داسيو نو ر با ركزي كند هاري و رونه هم كند هار تهراغلل او صفد رجنگك دشاه شجاع زوي جى دخهل و رو رتيمو رو روستهدكند هار حا كم و - هندوستان ته و تبنتيده همدغسى

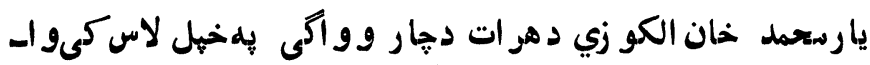

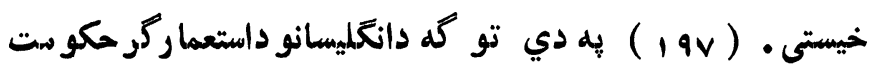

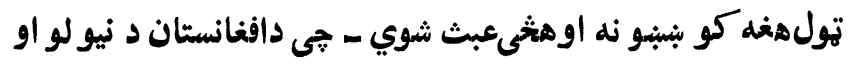

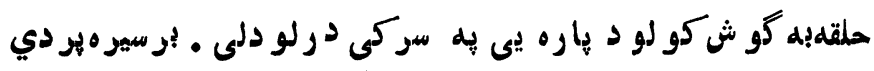

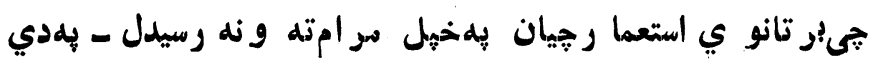

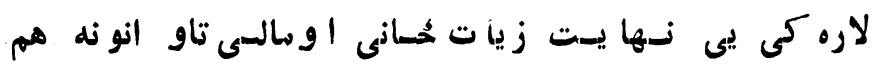

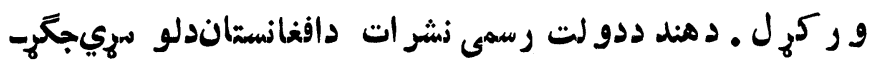

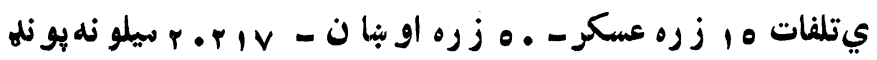
- خركند و ي (

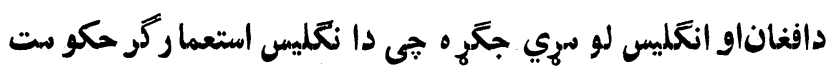

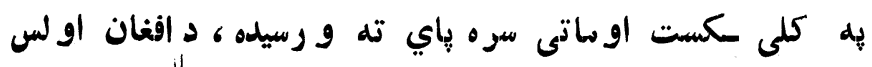

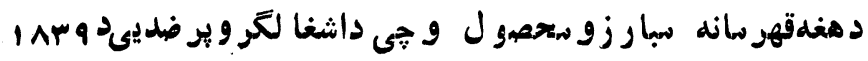

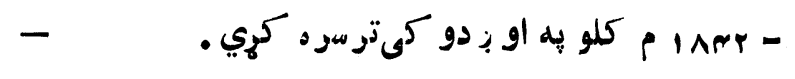

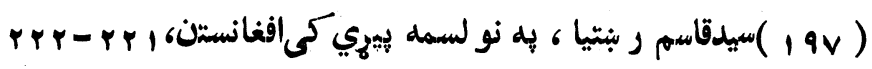

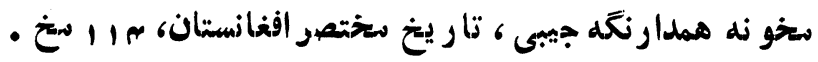

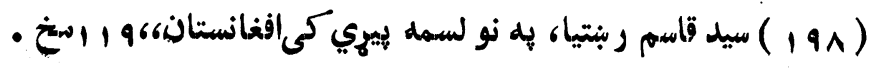




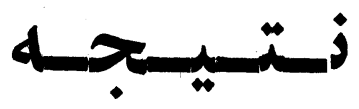

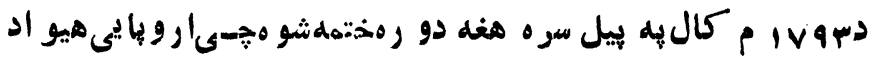

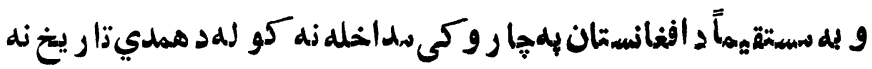

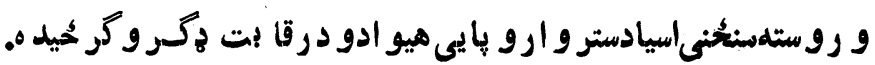
فو انسو يانو انظليسانو ا و و وسانوهو يو هدتهر اندر بار تسهلا رهبيدا

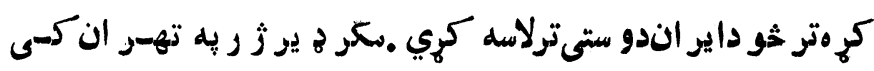
دنا بليو نذدانو رونو يهذر يعه او بر هـندباندىيد شاهز مساندير غل

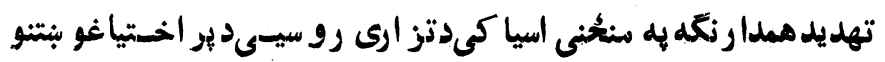

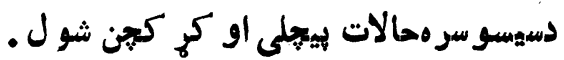

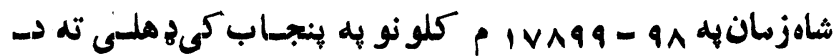

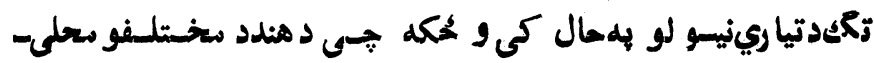

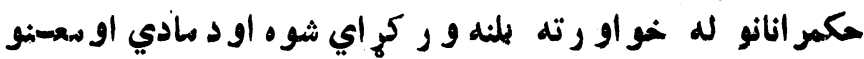

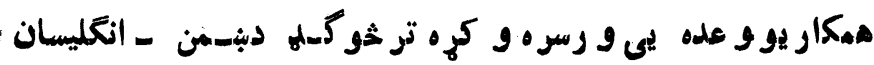

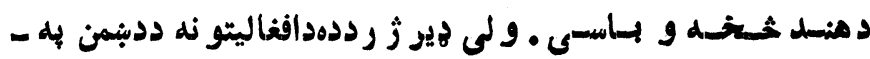

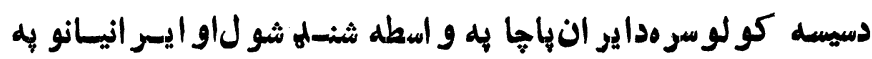

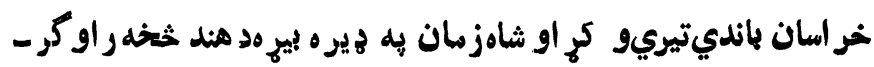

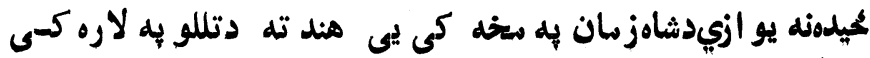




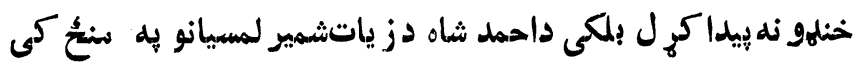
كى يى داسى دنفاق تخم و ثيند ميجى دهغه بهلو اسطه ددر انيانو -

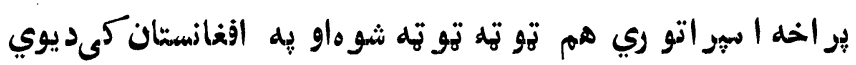

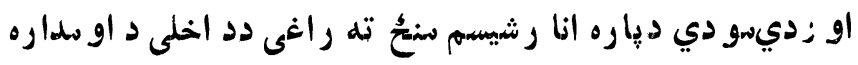

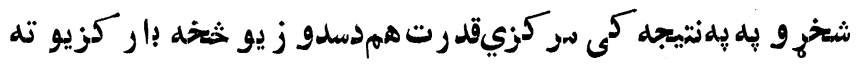

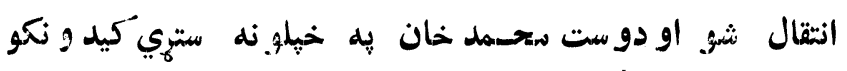

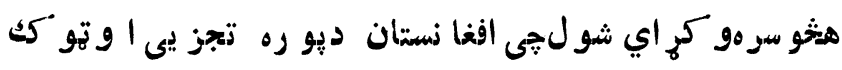
كو لو خخه وساتى .

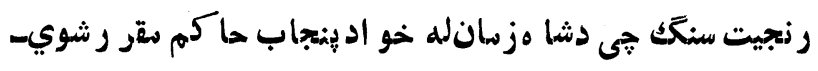

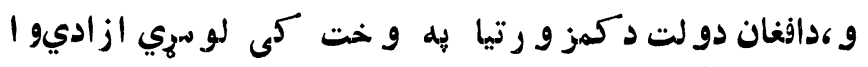
خستله او دستلج در ياب بله شمال غر بى سيمه كىبى ديو مبيا

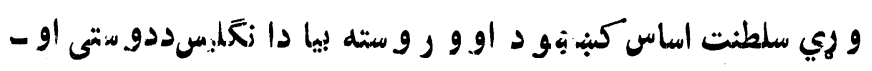

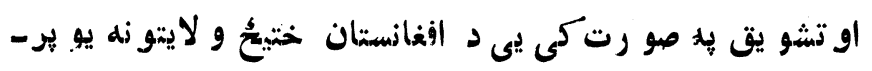

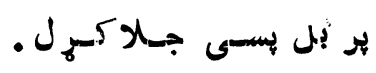

كندهار او هو ات هم بهديو خت كى دمركز خخخهجلاداداره كيدل.

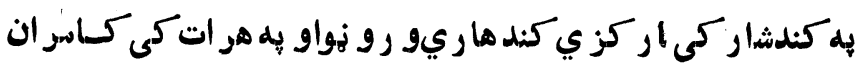

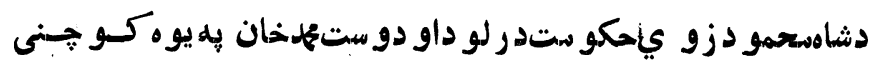

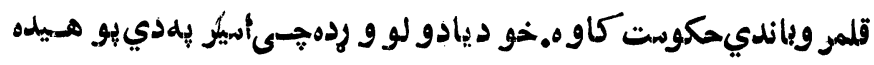

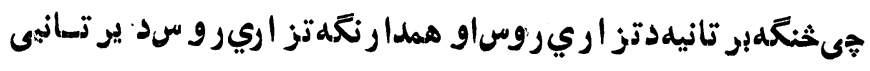
بو خلاف استعمال كري . 


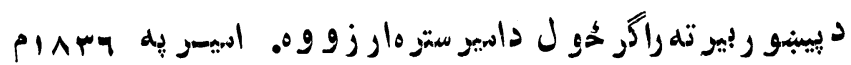

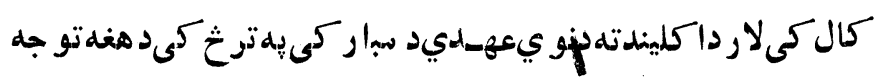

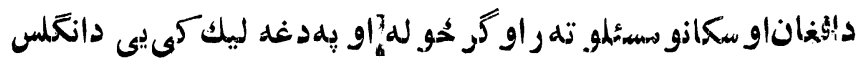

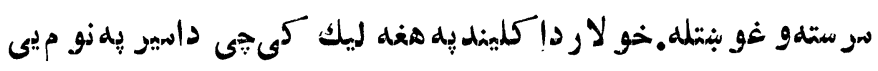

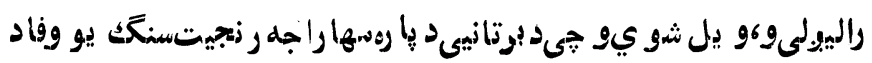

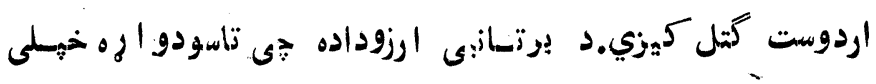

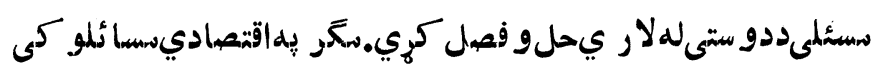

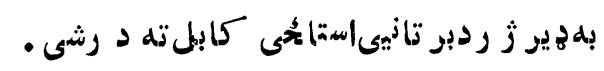

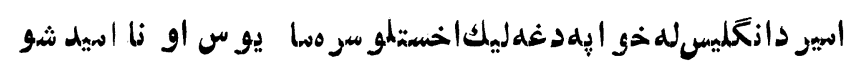

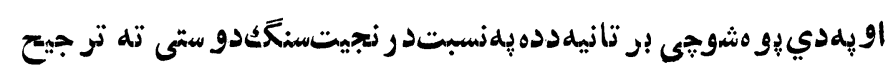

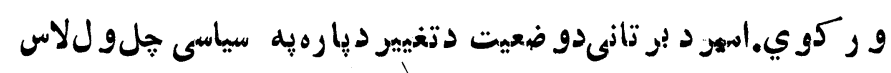

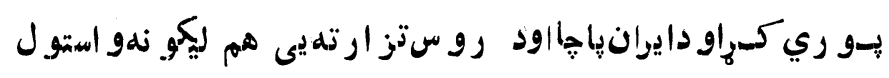

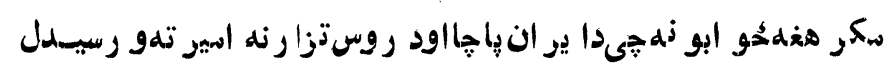

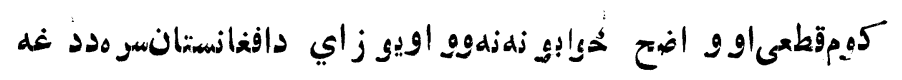
هيو ادو همدر دي يیى بنكا ره كو له .

دازكَليسدو لت كا بل تلهدر الكساندر بر نس در اليبولو تصميمو نيو

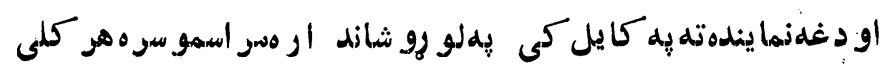

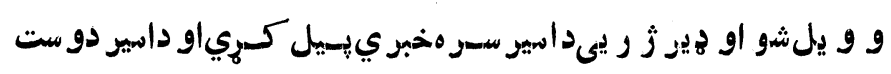

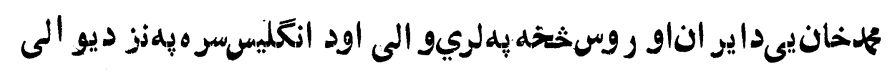

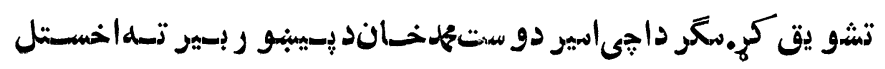




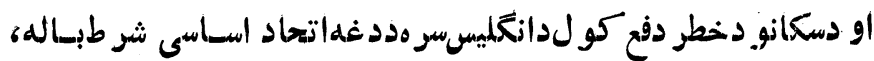

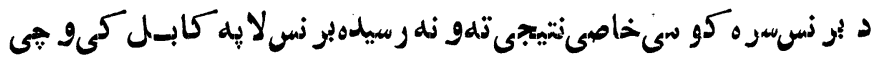

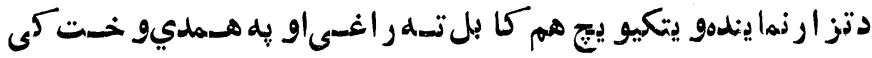
دهر ات كللا بندي همرداير انيانو لهخو ارو انهو ه.د هر اتستسر اتيسزو يك مو قفاو هغdلار يجيىدهر اتخخهاير ان، كندهار، كابل، اوبو تانوي هندتدتيو يدلى،ازكليسىو اكمنو تdخاصاهميتد رلو د.د بونسناكاسى

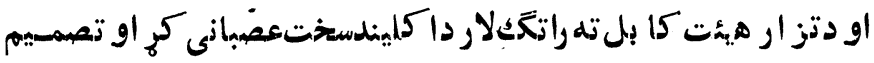

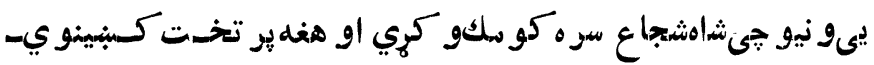

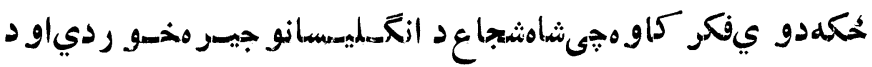

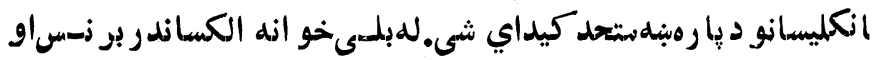

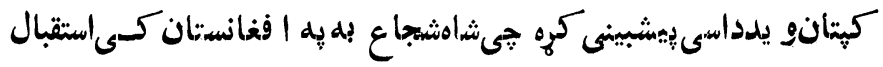

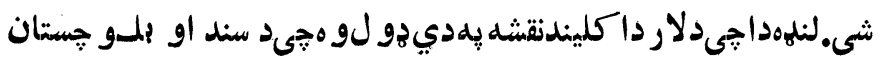
لهلار ي كندهار ساو له هغهُحايه هر اتتهد س-حاصسره او كلابسنديد

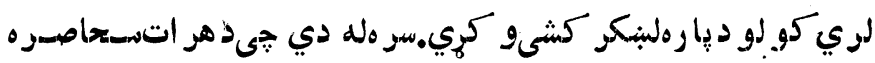

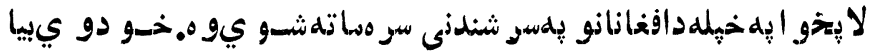
همد رو سد هيئتر اتخكفيوه بهانه وكر حو لهاو د بار كز يو سو دار اـ

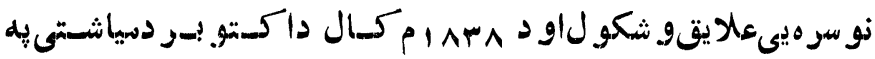

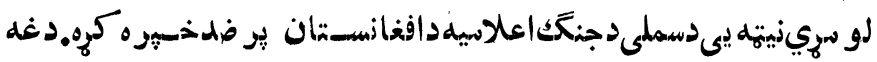

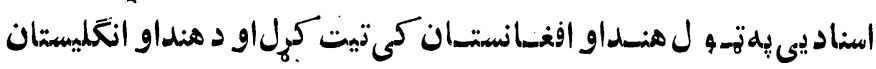

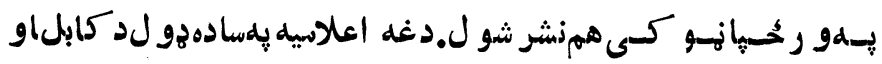

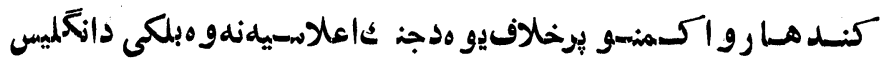




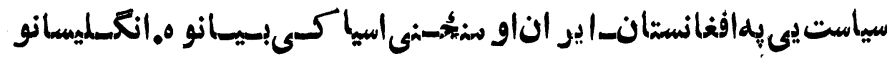

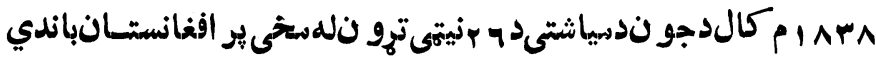

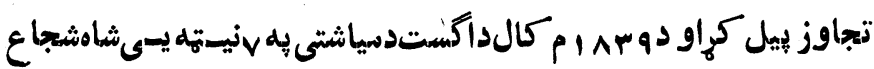

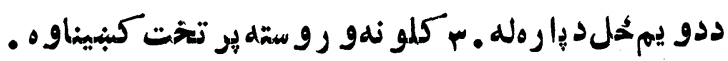

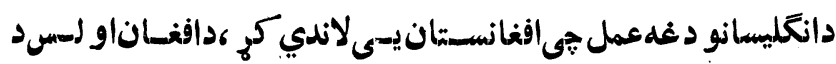

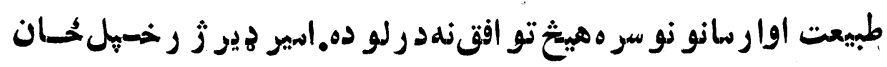

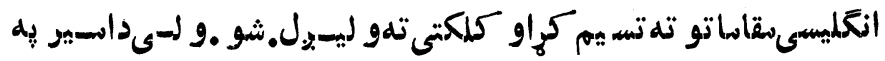

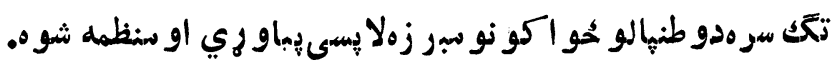

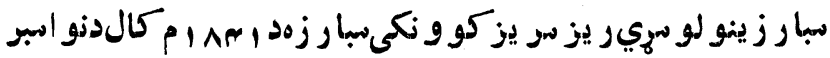

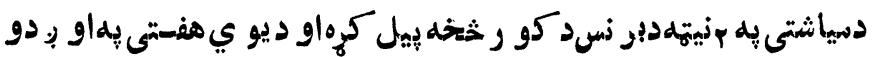
كى يى كا بل د استعمار كر انو ختخهاز اد كراو بو تانو ي يو خحيسان يهخسو متحدو دو كلاككانو كى كلا بند شو ل.بوتانيىسياسى نمسا ي-ندهـك-ناتيند

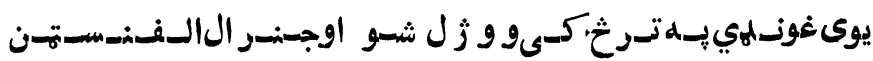
هم ذهيو ز ردبر تاذوي يوحُ ديو روتسلميدو تر و نلاسليك كي .خو دغه

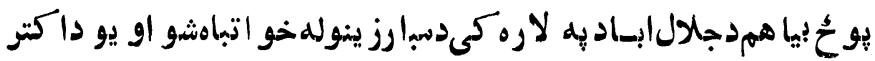

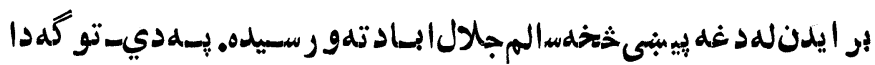

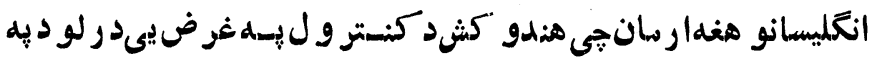
يو هفاجعdآنيز هتو گلهتم شو م

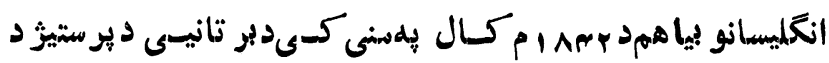

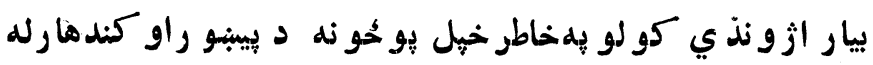




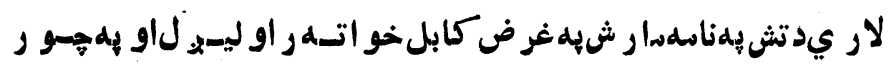

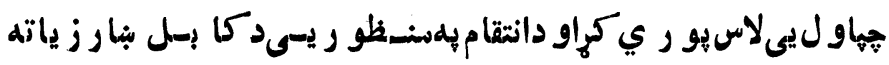

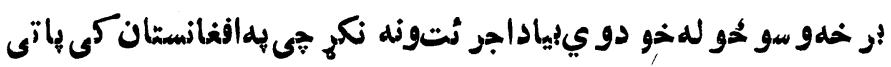

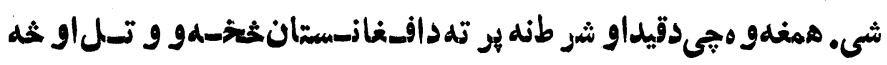

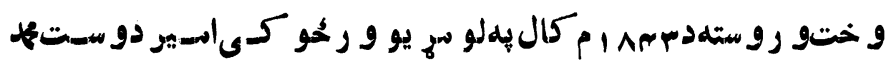

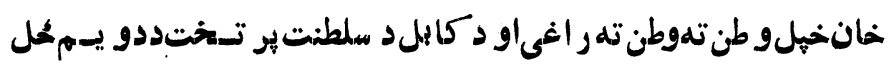

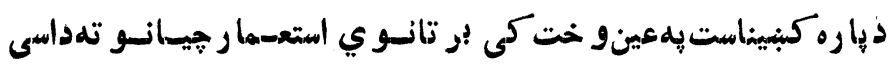

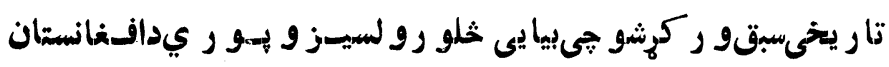

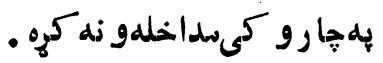

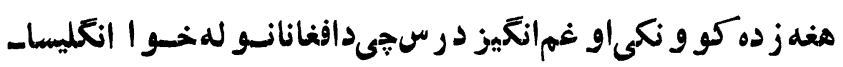

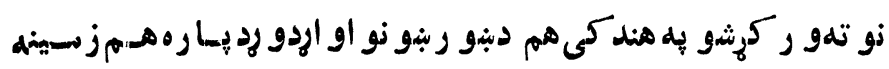

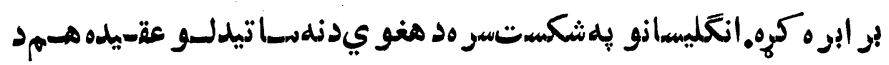

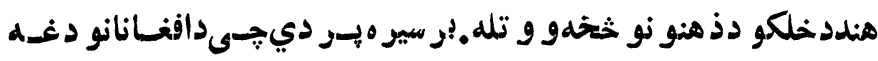

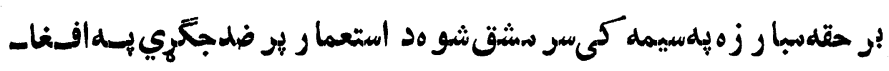

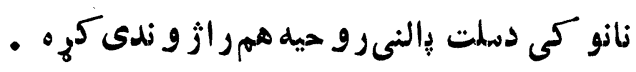

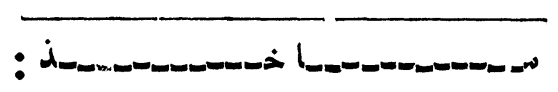

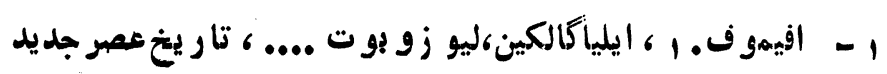

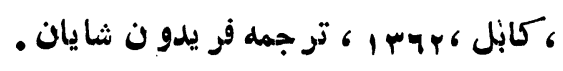

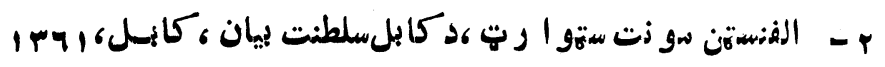

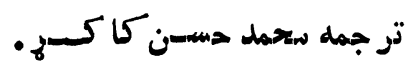




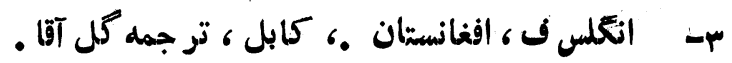

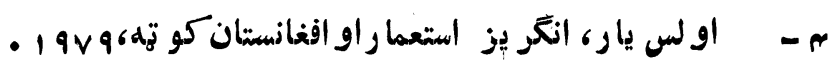

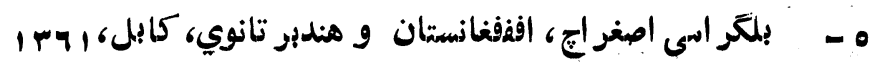
تر جمه عبدا لو ها ب فنا يى .

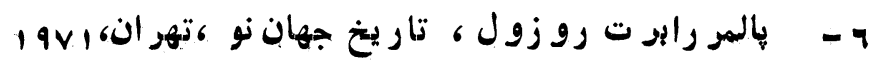
6 تو جمه ـ عبدالقاسم طا هوب .6

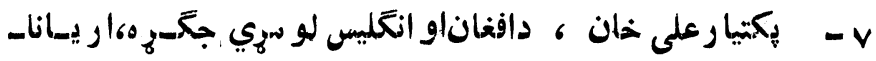

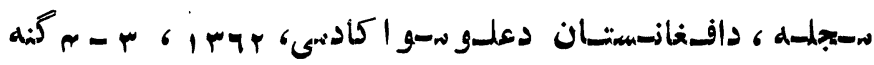

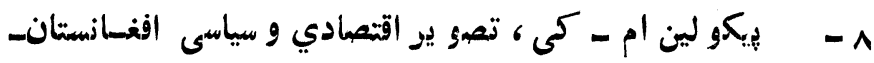

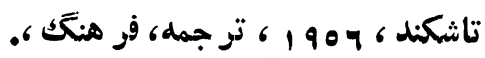

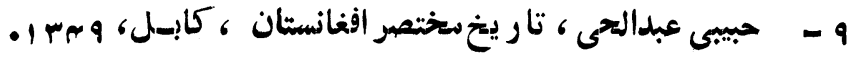

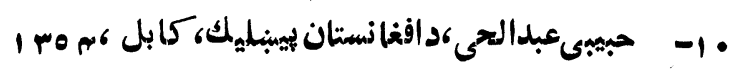

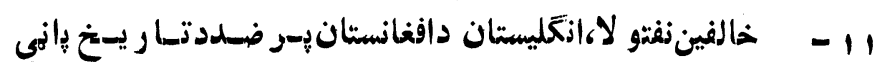
ماسكسو 619

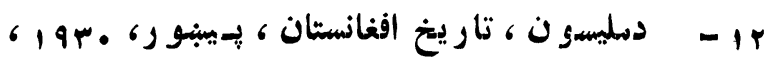
تو جمه سنسشـى احسمسـدجـان .

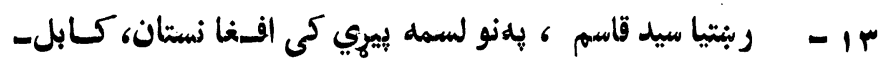

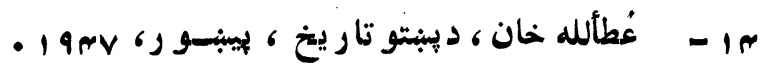
$-101-$ 


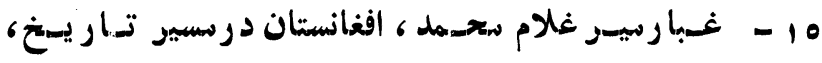

كابل ك 197v

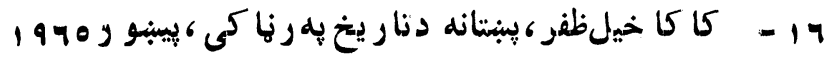

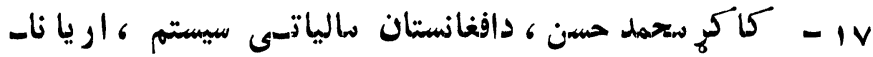

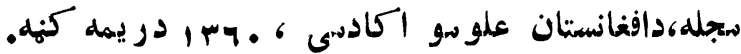

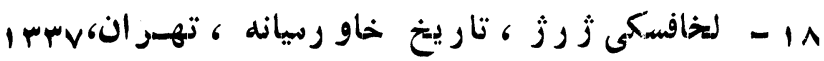

$$
\text { ، ترجمه ،داكتر هادي جز ايري . }
$$

9 19 او قبايلو دجهارو و زارت كستتنر، تسر جمه فـر هـا دظـر يفى

عبدالطيف طالبى •

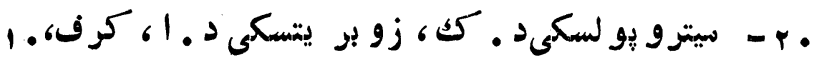

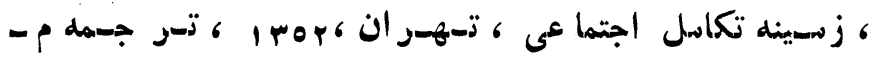

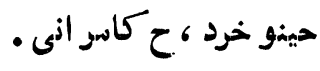

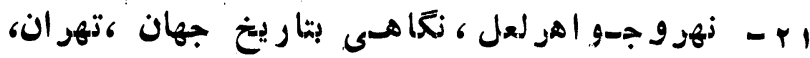

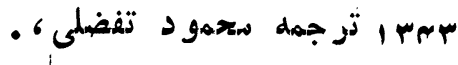

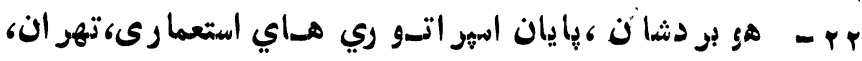

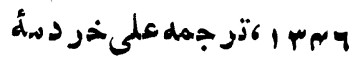


: وهمهمالسميادنظز:

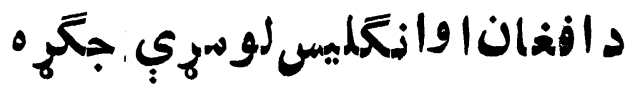

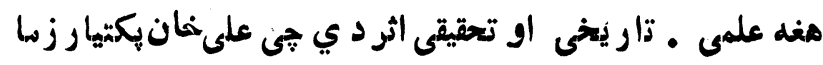

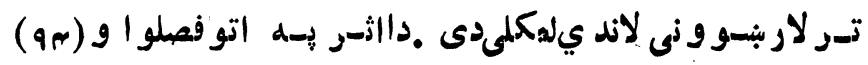

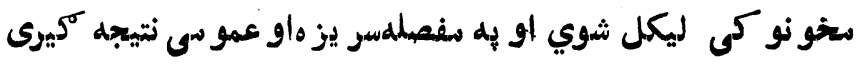

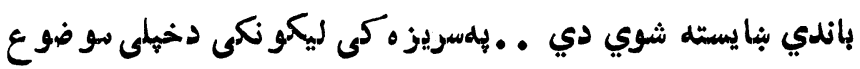

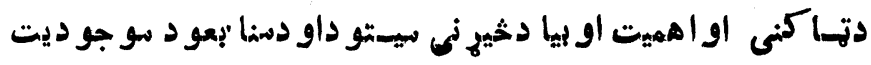
هه إب يو عمو :ىنظرور انسدي كوي.

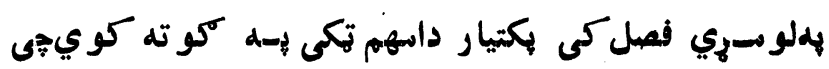

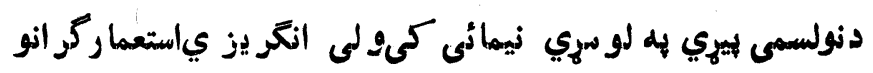

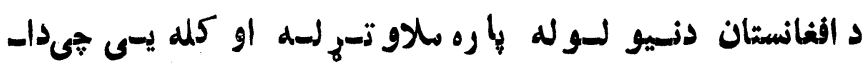

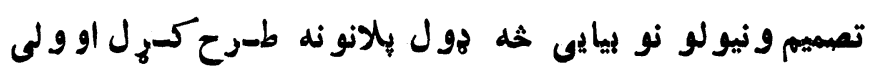

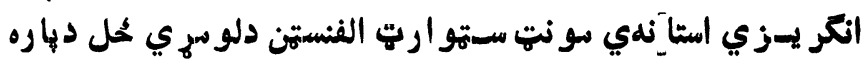

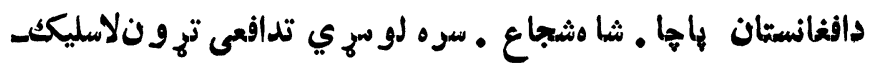




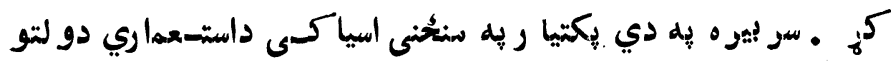

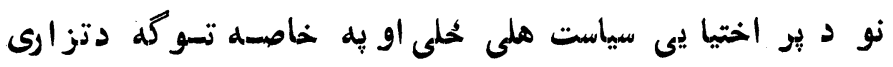

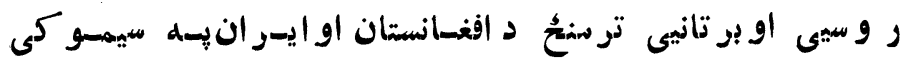

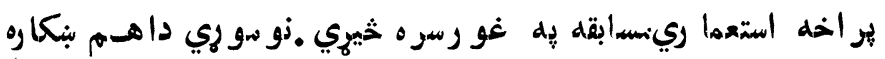

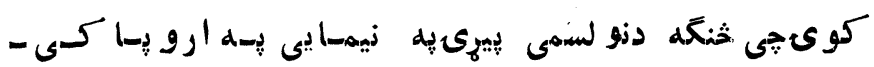
دناسيو زاليز م او وطن پالنى افـر اطسى احسساسات او دصنعتى انقلاب

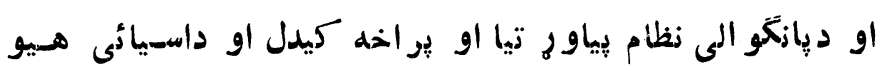

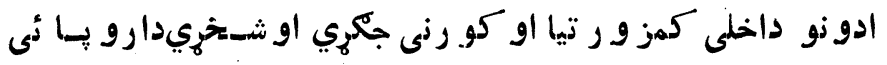
استعهماري قدرتو زو پٍه اسبو يا ليستى سيساست باندي خه اغيزهدر

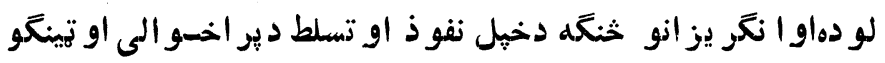

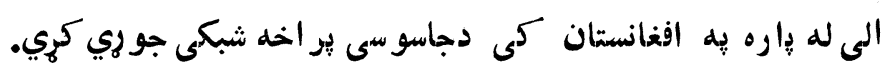

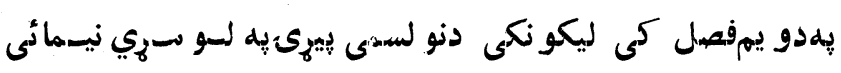
كى دافغانستان اقتصادي اوسياسى حالات تر كتنى لانسدي نيسولـى

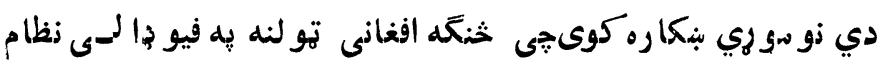

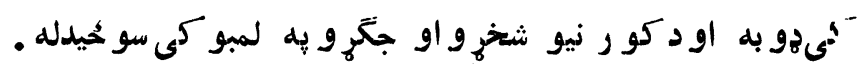

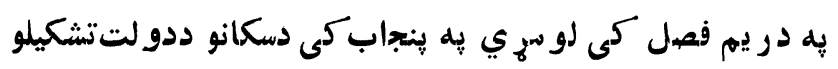
ل لاو دهغى بر اختيا يیىسياست او بيا دافغان اوسك دو لتسو نو تسو منسئ لانجى او شخري او در نجيت سنكَ او شساه شجراع تسر مسنع ار يكسى او دشاه شجاع بيا هلى محلى دتخت له هـاره تر خيسه نىلاندينيولـ

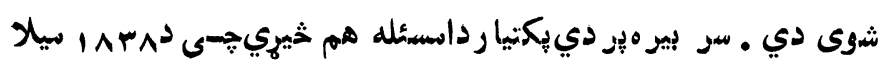




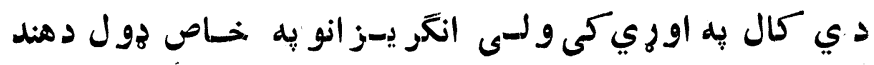

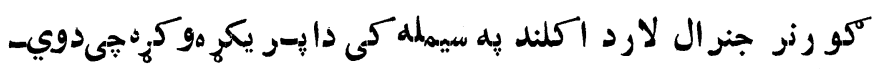

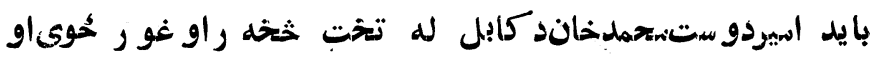
دنو مو هي ير حُاي شاه شجاع جيى ددو ي كمو هامكىو و او دلندناو

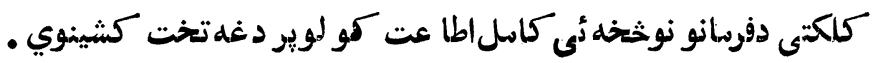

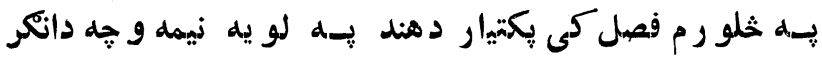
يزي استعما ربنسبت كيبنو دل او به ميختلفو عصر و نو كى ئى بير اخيدل

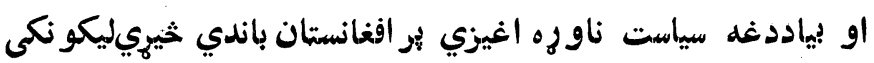

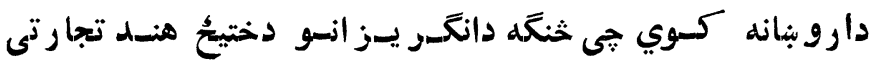
كمينى و روو رو ديه يو لوي اقتصادي او سياسى استعهارياركان

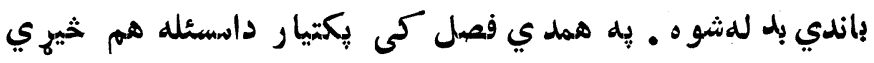
جيى ولى او خنحَه انكو يز انو ـ اير انيان او سكان دو إره تشو يقول

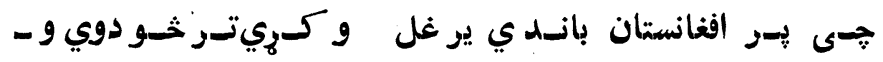
كولاي شى جـى دافغانستان له كمزو ر تيا خخه كَّه و اخلى .

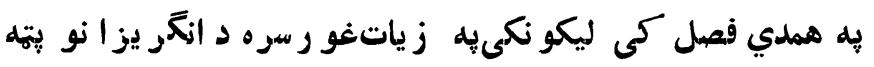

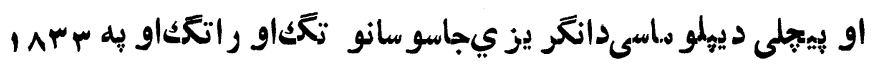

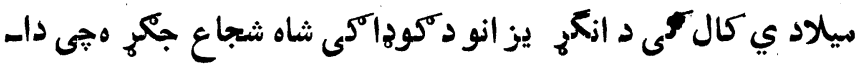

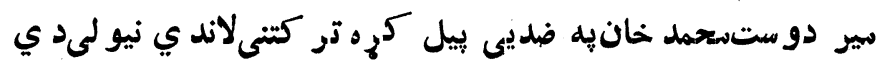

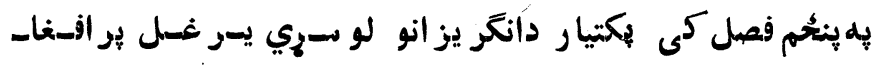

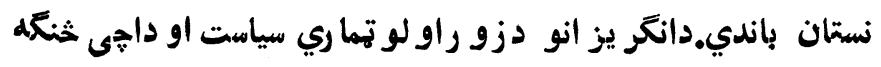

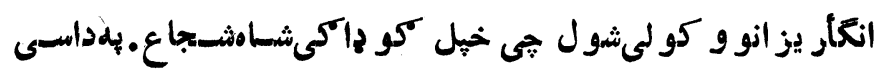




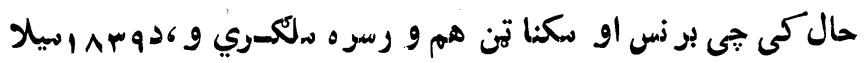

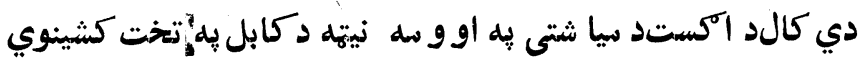

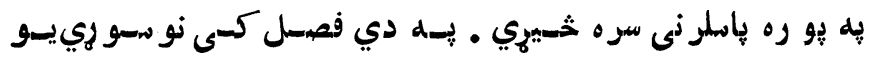

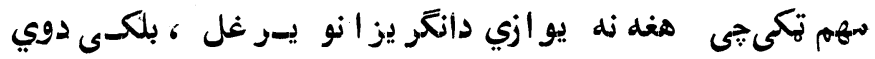

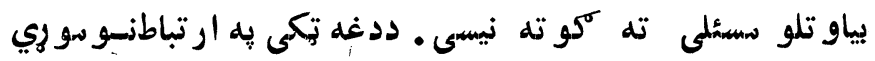

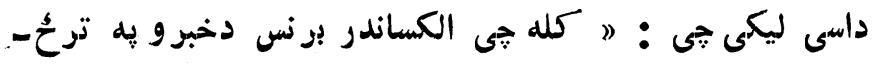

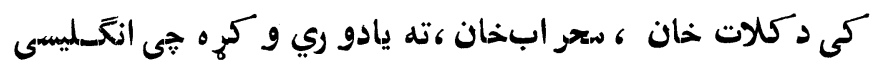

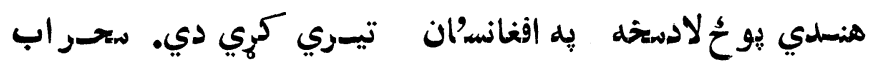

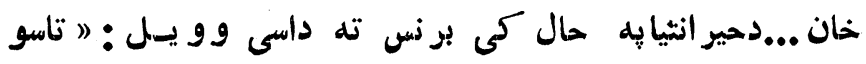

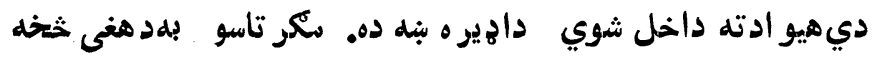

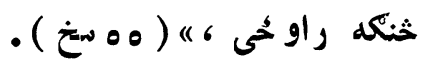

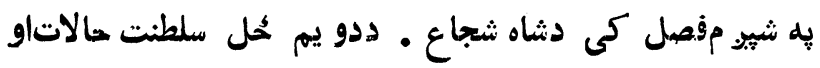

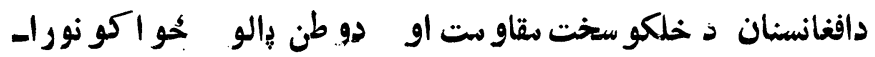

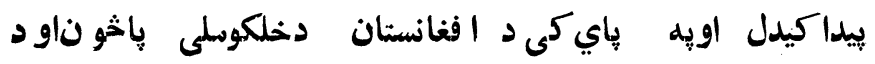

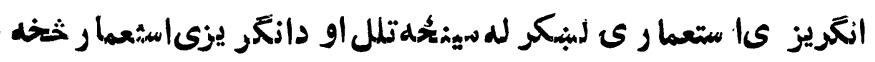

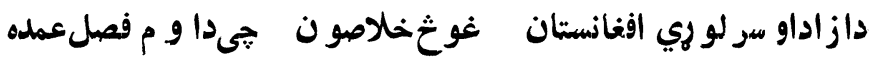
مو ضوع تشكيلوي به زو وه تو مكه خيزل شويدي .

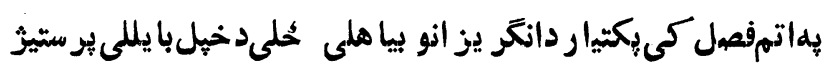
ديياتر لاسه كو لولهياره خيرياو بهدياي كى دانكو يز انو استعمارى

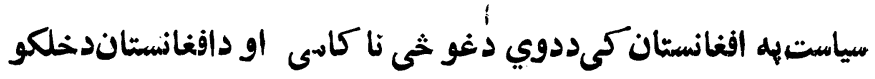
دو طن بالنىاو از اديغو بنتنى يه هكلمعمو سىنتيجه كيري كوي 


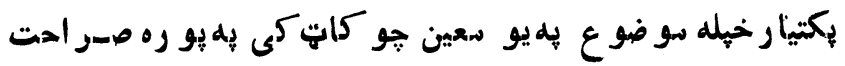

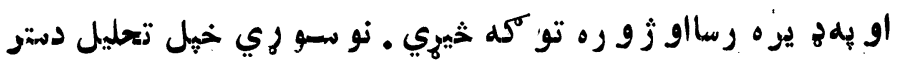

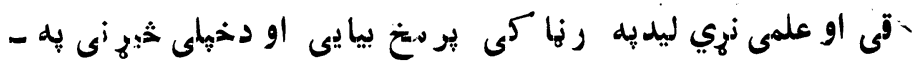

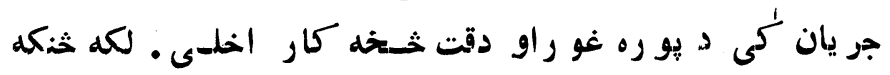

جى يو سؤ رخ بايد او سى، يه همديدو لن نو مو ه ى لهتشبو احساساتو

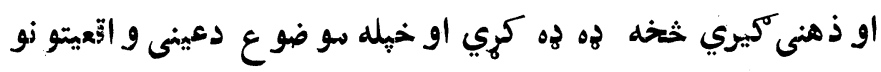

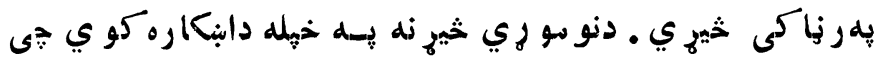

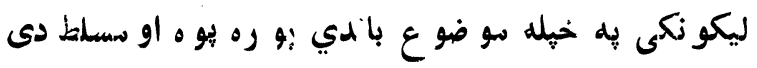

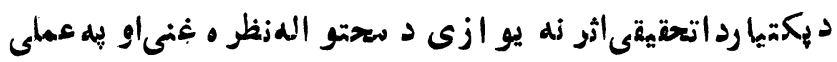

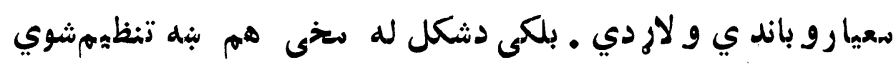

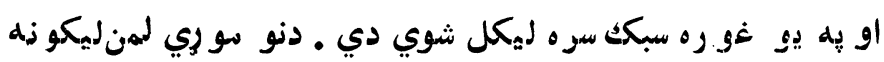
همدابنكاره كوي جى ليكو نكى دهيرو سعتبرو لوسي زيو او دويم

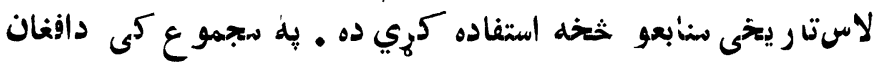
او انكلمس لو سري جكيه ديو علمى ، تار يخخى او تحقيقى اثهر دي

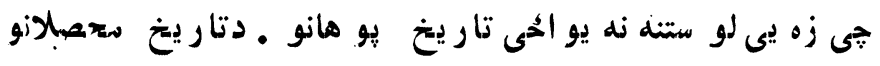

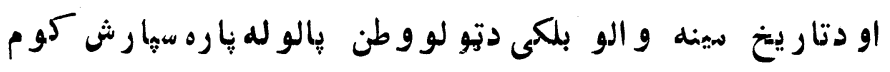
زه به باي كىديكنيا رله بي رمنو رلاز يات علمىبر ليتو بو نه غو اله م. دكتو ر بر هان الدين حساس) بو هندوى) دكابل ديو هنتو ن داجتماعى علو مو ديو هنشّى استياد

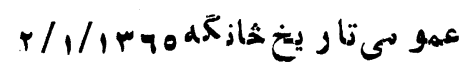



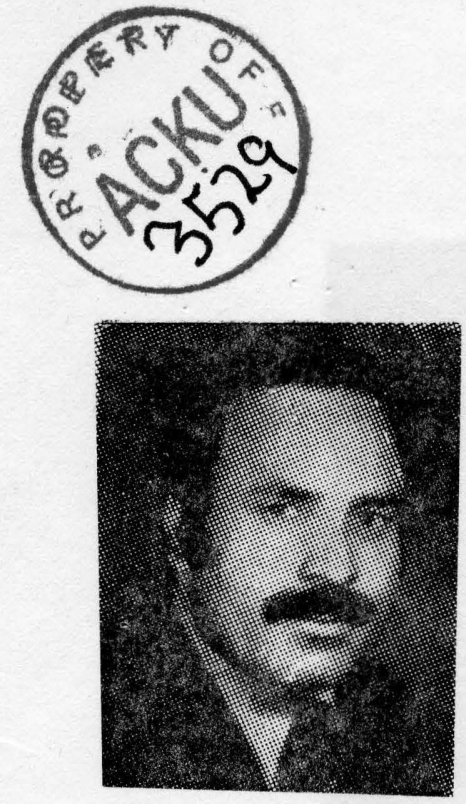

على خان نكتيار دزيركل مشهور به كوتوال زوى دكل هياجا لمسىىى.

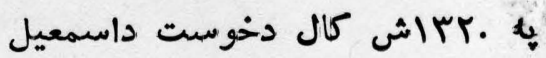
خيلو ددروالو دكوز عليوات نيه كلى كى، زيبزيدلى، خهل ابتدايى زده كرى

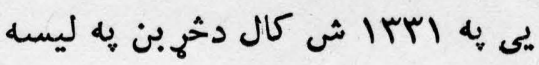

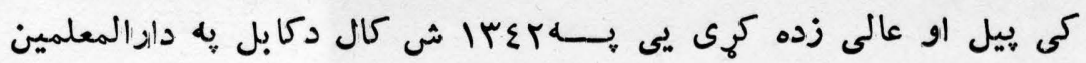

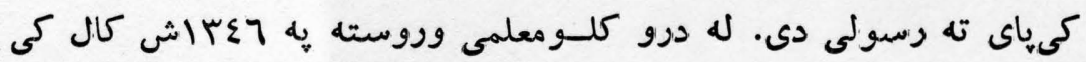

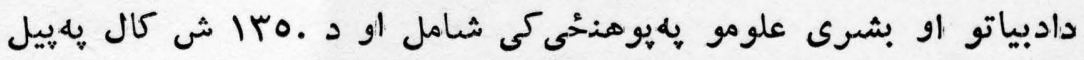

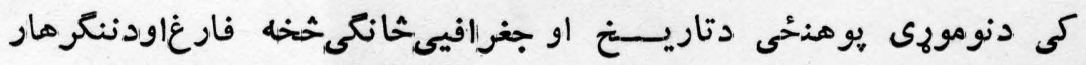

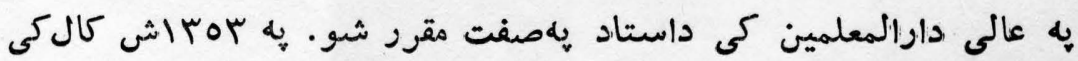

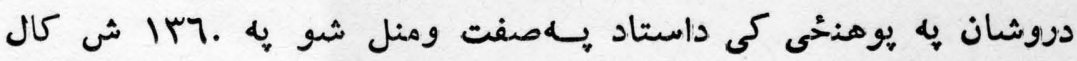
كى دافغانستان دعلومو اكادمىدتاريخدانستيتوت غهى شو او تر اوسه به. دى انستيتوت ك ىخيله دنده اجراكوى . 